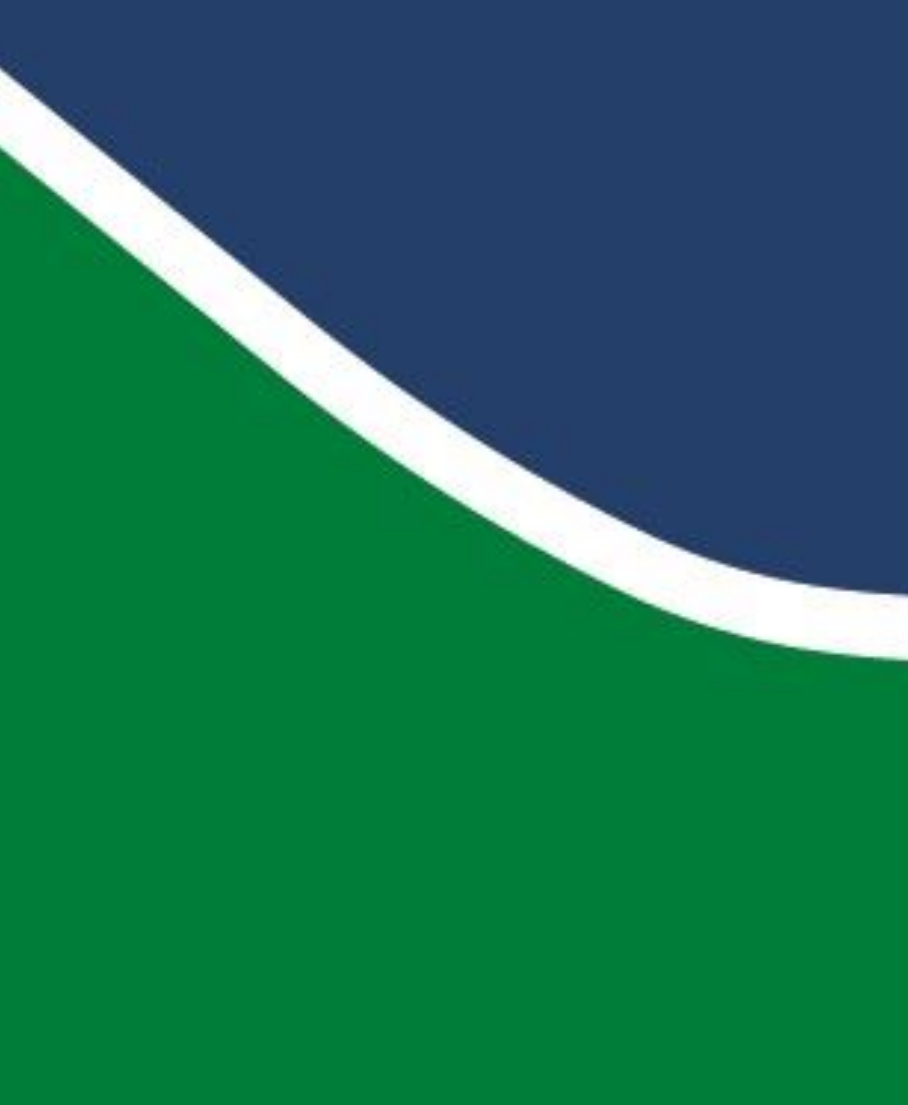

AVALIAÇÕES NÃO DESTRUTIVAS PARA O MONITORAMENTO DE MADEIRAS SUBMETIDAS A FUNGOS APODRECEDORES

ELIAN MENESES OLIVEIRA

DISSERTAÇÃO DE MESTRADO

DEPARTAMENTO DE ENGENHARIA FLORESTAL 
UNIVERSIDADE DE BRASÍLIA

FACULDADE DE TECNOLOGIA

DEPARTAMENTO DE ENGENHARIA FLORESTAL

\section{AVALIAÇÕES NÃO DESTRUTIVAS PARA O MONITORAMENTO DE MADEIRAS SUBMETIDAS A FUNGOS APODRECEDORES}

\section{ELIAN MENESES OLIVEIRA}

ORIENTADOR: PROF. DR. ALEXANDRE FLORIAN DA COSTA COORIENTADOR: PROF. DR. JEZ WILLIAN BATISTA BRAGA

DISSERTAÇÃO DE MESTRADO EM CIÊNCIAS FLORESTAIS

PUBLICAÇÃO: PPGEFL.DM - 263 /2016

BRASÍLIA/DF: FEVEREIRO - 2016 
UNIVERSIDADE DE BRASÍLIA

FACULDADE DE TECNOLOGIA

DEPARTAMENTO DE ENGENHARIA FLORESTAL

PROGRAMA DE PÓS-GRADUAÇÃO EM CIÊNCIAS FLORESTAIS

\section{"Avaliações não destrutivas para o monitoramento de madeiras submetidas a fungos apodrecedores"}

\section{ELIAN MENESES OLIVEIRA}

DISSERTAÇ̃̃O DE MESTRADO ACADÊMICO SUBMETIDA AO PROGRAMA DE PÓS-GRADUAÇÃO EM CIÊNCIAS FLORESTAIS, DO DEPARTAMENTO DE ENGENHARIA FLORESTAL, DA FACULDADE DE TECNOLOGIA DA UNIVERSIDADE DE BRASÍLIA, COMO PARTE DOS REQUISITOS NECESSÁRIOS PARA A OBTENÇÃO DO GRAU DE MESTRE.

APROVADA POR:

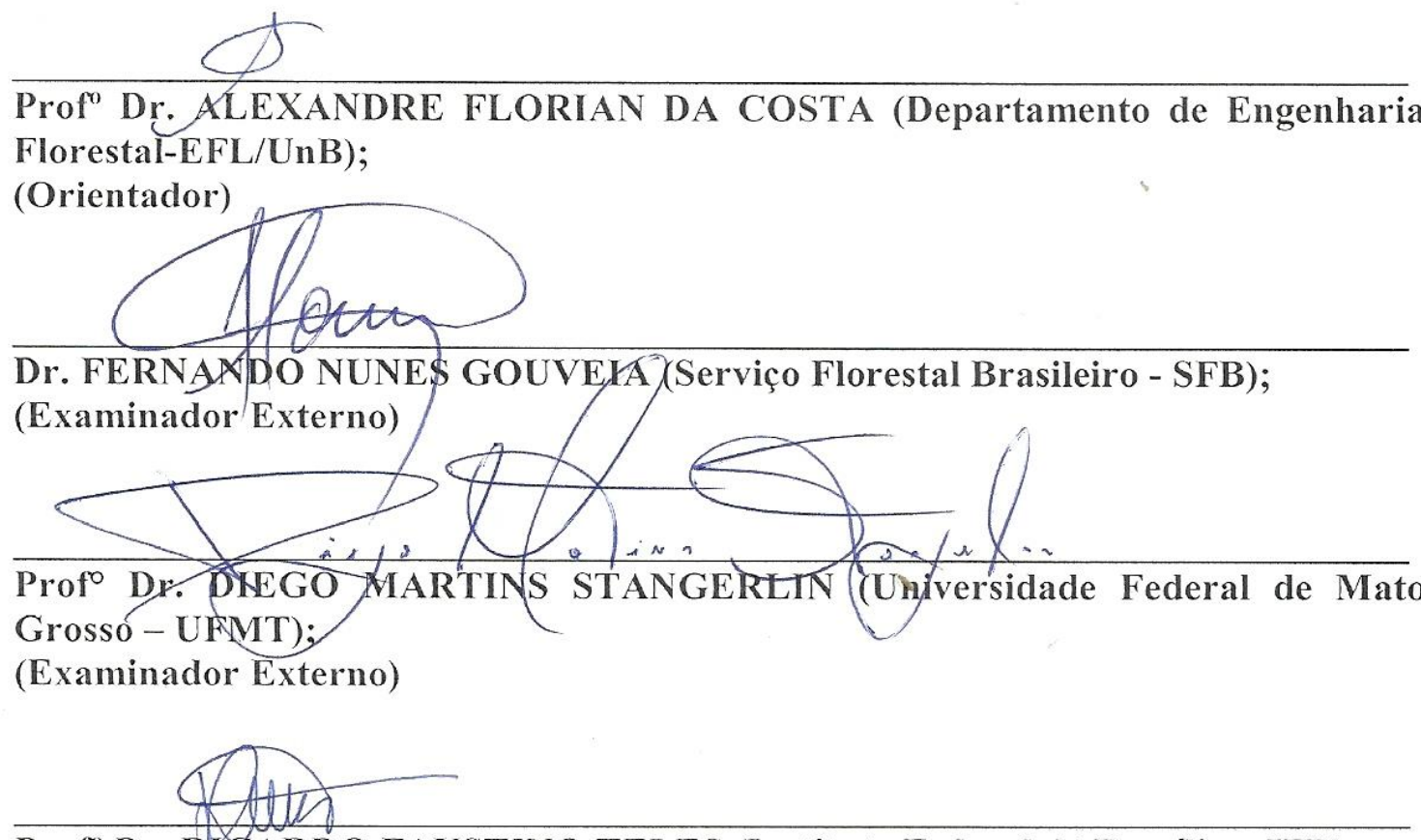

Prof ${ }^{\circ}$ Dr. RICARDO FAUSTINO TELES (Instituto Federal de Brasília - IFB). (Examinador Suplente)

Brasília-DF, 19 de fevereiro de 2016. 
UNIVERSIDADE DE BRASÍLIA

FACULDADE DE TECNOLOGIA

DEPARTAMENTO DE ENGENHARIA FLORESTAL

\begin{abstract}
AVALIAÇÕES NÃO DESTRUTIVAS PARA O MONITORAMENTO DE MADEIRAS SUBMETIDAS A FUNGOS APODRECEDORES
\end{abstract}

ELIAN MENESES OLIVEIRA

DISSERTAÇÃO DE MESTRADO ACADÊMICO SUBMETIDA AO PROGRAMA DE PÓS-GRADUAÇÃO EM CIÊNCIAS FLORESTAIS, DO DEPARTAMENTO DE ENGENHARIA FLORESTAL, DA FACULDADE DE TECNOLOGIA DA UNIVERSIDADE DE BRASÍLIA, COMO PARTE DOS REQUISITOS NECESSÁRIOS PARA A OBTENÇÃO DO GRAU DE MESTRE.

APROVADA POR:

Prof $^{o}$ Dr. Alexandre Florian da Costa (Departamento de Engenharia Florestal - EFL/UnB); (Orientador)

Dr. Fernando Nunes Gouveia (Serviço Florestal Brasileiro - SFB);

(Examinador externo)

Prof $^{o}$ Dr. Diego Martins Stangerlin (Universidade Federal de Mato Grosso - UFMT); (Examinador externo)

Prof $^{o}$ Dr. Ricardo Faustino Teles (Instituto Federal de Brasília - IFB) (Examinador suplente)

BRASÍLIA/DF, 19 DE FEVEREIRO DE 2016. 


\section{FICHA CATALOGRÁFICA}

\section{OLIVEIRA, ELIAN MENESES}

Avaliações Não Destrutivas para o Monitoramento de Madeiras Submetidas a Fungos Apodrecedores [Distrito Federal] 2016

128p., 210 x 297 mm (EFL/FT/UnB, Mestre, Dissertação de Mestrado - Universidade de Brasília. Faculdade de Tecnologia.

Departamento de Engenharia Florestal.
1. Biodeterioração
2. Colorimetria
3. Fluorescência
4. DRIFT-MIR
I. EFL/FT/UnB
II. Título (série)

\section{REFERÊNCIA BIBLIOGRÁFICA}

OLIVEIRA, E. M. (2016). Avaliações Não Destrutivas para o Monitoramento de Madeiras Submetidas a Fungos Apodrecedores. Dissertação de Mestrado em Ciências Florestais, Publicação, Departamento de Engenharia Florestal, Universidade de Brasília, Brasília, DF, $128 \mathrm{p}$.

\section{CESSÃO DE DIREITOS}

AUTOR: Elian Meneses Oliveira

TÍTULO: Avaliações Não Destrutivas para o Monitoramento de Madeiras Submetidas a Fungos Apodrecedores.

GRAU: Mestre ANO: 2016

É concedida à Universidade de Brasília permissão para reproduzir cópias desta dissertação de mestrado e para emprestar ou vender tais cópias somente para propósitos acadêmicos e científicos. $\mathrm{O}$ autor reserva outros direitos de publicação e nenhuma parte dessa dissertação de mestrado pode ser reproduzida sem autorização por escrito do autor.

Elian Meneses Oliveira

QSF 06, casa 115, Taguatinga Sul.

72025-560, Taguatinga, DF, Brasil.

email: elian.meneses.oliveira@gmail.com 


\section{AGRADECIMENTOS}

A Deus, por ter me sustentado e me dado forças para concluir mais esta etapa.

Ao meu querido orientador, Professor Alexandre Florian da Costa, pela orientação, paciência, confiança e por sempre acreditar em mim.

Ao Professor Jez Willian Batista Braga, pela coorientação, apoio, confiança e conhecimentos transmitidos.

Aos queridos amigos do LPF/SFB: Fernando Gouveia, Marcelo Fontana, Anna Sofya, Getúlio, Fernando Ananias e Ricardo, por toda a ajuda, ensinamentos e tempo dedicado ao desenvolvimento deste trabalho. A participação de vocês foi extremamente essencial, pois eu não teria conseguido realizar um trabalho de excelência sem o total apoio de vocês. Muitíssimo obrigada!

À Dra. Tereza Pastore, pela amizade, paciência, auxílio e todo conhecimento transmitido durante a execução deste projeto.

À Universidade de Brasília e ao Programa de Pós-Graduação em Ciências Florestais (PPGEFL), pela oportunidade e todo conhecimento direcionado à melhoria da minha formação profissional.

Ao LPF/SFB, por abrir as portas para a realização deste projeto, permitindo o uso de laboratórios e equipamentos.

Aos Professores Diego Stangerlin e Ricardo Teles, por participarem da banca examinadora e por todas as sugestões e correções.

À Coordenação de Aperfeiçoamento de Pessoal de Nível Superior (CAPES), pelo apoio financeiro através da concessão da bolsa de mestrado.

À minha família, pelo apoio incondicional, amor, confiança, pelo estímulo e paciência nas horas difíceis e de cansaço extremo. Vocês foram o meu suporte.

Ao meu namorado Henrique Duarte, pelo amor, apoio, compreensão nos inúmeros momentos de ausência e por me incentivar a dar o meu melhor sempre.

Aos meus amigos, Marcella Hermida e Robert Rossi, pela grande amizade e apoio.

A todos que contribuíram para a realização deste trabalho, muito obrigada! 
Aos meus pais,

Francisco das Chagas Oliveira

Francineide Meneses Oliveira

Aos meus avós,

Antônio Meneses e Francisca Meneses

Francisca Oliveira

José Gomes (in memorian) e Maria José

Dedico 


\title{
RESUMO
}

\section{AVALIAÇÕES NÃO DESTRUTIVAS PARA O MONITORAMENTO DE MADEIRAS SUBMETIDAS A FUNGOS APODRECEDORES}

\author{
Autor: Elian Meneses Oliveira \\ Orientador: Prof. Dr. Alexandre Florian da Costa \\ Coorientador: Prof. Dr. Jez Willian Batista Braga \\ Programa de Pós-Graduação em Ciências Florestais
}

\section{Brasília, 19 de Fevereiro de 2016}

Este estudo teve como objetivo monitorar e avaliar, por meio de técnicas não destrutivas, o processo de biodeterioração das madeiras de Simarouba amara (marupá) e Eucalyptus saligna (eucalipto) submetidas aos fungos Trametes versicolor (podridão branca) e Gloeophyllum trabeum (podridão parda). O ensaio de apodrecimento acelerado ocorreu durante 12 semanas, e empregou-se uma adaptação da norma ASTM D 2017. As propriedades biológicas foram avaliadas por meio da perda de massa decorrente da exposição aos fungos apodrecedores. As técnicas não destrutivas de colorimetria, espectroscopia no infravermelho médio (DRIFT-MIR) e fluorescência molecular foram utilizadas para avaliar alterações nos parâmetros colorimétricos e nas propriedades químicas das espécies de madeira nos diferentes estágios de ataque dos fungos. Os resultados mostraram que a madeira de eucalipto apresentou maior resistência natural quando comparada à de marupá. O fungo de podridão parda apresentou ataque mais severo às madeiras, levando a uma maior alteração das propriedades tecnológicas estudadas. Os parâmetros mais alterados foram $\mathrm{L}^{*}, \mathrm{a}^{*} \mathrm{e} \mathrm{b}^{*}$, sendo os principais estimadores da resistência natural das madeiras de marupá e eucalipto. O monitoramento dos parâmetros químicos por meio de DRIFT-MIR possibilitou a visualização de deformação na banda referente à celulose $\left(899 \mathrm{~cm}^{-1}\right)$ após o ataque do fungo de podridão parda. Entretanto, após o ataque do fungo de podridão branca, os espectros não foram alterados em forma, apenas em intensidade. A análise da fluorescência emitida pelas madeiras após o ataque de podridão branca e parda permitiu a detecção precoce do ataque e a discriminação entre os fungos apodrecedores até a quarta semana de exposição. Os ensaios não destrutivos de colorimetria, espectroscopia no infravermelho médio (DRIFT-MIR) e fluorescência molecular mostraram ser capazes de detectar alterações nos parâmetros colorimétricos e químicos logo nas primeiras semanas, além de permitir a discriminação entre os ataques de podridão branca e parda.

Palavras-chave: biodeterioração; colorimetria; DRIFT-MIR; fluorescência. 


\title{
ABSTRACT \\ NON-DESTRUCTIVE ASSESSMENTS TO MONITORING WOODS SUBMITTED TO DECAY FUNGI
}

\author{
Author: Elian Meneses Oliveira \\ Advisor: Prof. Dr. Alexandre Florian da Costa \\ Co-advisor: Prof. Dr. Jez Willian Batista Braga \\ Postgraduate Program in Forest Sciences
}

\section{Brasília, February of 2016}

The present study aimed to monitore and evaluate, using non-destructive techniques, the biodeterioration process of Simarouba amara and Eucalyptus saligna woods submitted to Trametes versicolor (white rot) and Gloeophyllum trabeum (brown rot). The accelerated decay test occurred during 12 weeks, according to an adaptation of ASTM D 2017/2005. The biological properties were evaluated by weight loss due to the exposure to rot fungi. The non-destructive techniques of colorimetry, medium infrared spectroscopic (DRIFT-MIR) and molecular fluorescence were used to evaluate changes in colorimetric parameters and chemical properties of wood species in different levels of fungi decay. The results showed that Eucalyptus saligna wood presented a higher natural resistance when compared to Simarouba amara. Gloeophyllum trabeum presented a more severe attack to woods, leading to more changings in the technological properties studied. The most affected parameters were $\mathrm{L} *, \mathrm{a}^{*}$ and $\mathrm{b} *$, the main estimators of natural resistance of Simarouba amara and Eucalyptus saligna woods. The monitoring of chemical parameters through DRIFT-MIR allowed visual deformation in the band related to the cellulose $\left(899 \mathrm{~cm}^{-1}\right)$ after the Gloeophyllum trabeum decay. However, after the Trametes versicolor decay, the spectra have not changed in shape, only in intensity. The emitted fluorescence analysis by woods after the Trametes versicolor and Gloeophyllum trabeum decay allowed early detection and discrimination between them until the fourth week of exposure. The non-destructive tests of colorimetry, medium infrared spectroscopic and molecular fluorescence have shown to be capable of detecting changes in colorimetric and chemical parameters in the first few weeks, and also permitting the discrimination between white and brown rot.

Key words: biodeterioration; colorimetry; DRIFT-MIR; fluorescence. 


\section{SUMÁRIO}

1 INTRODUÇÃ

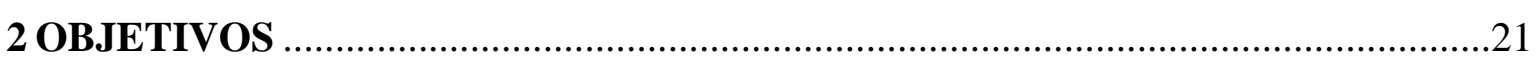

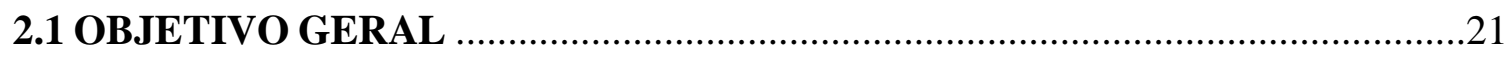

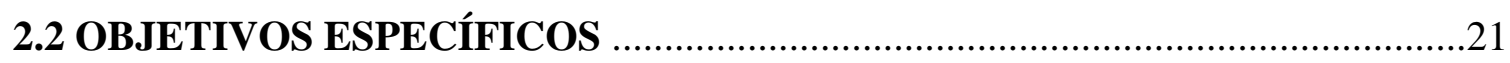

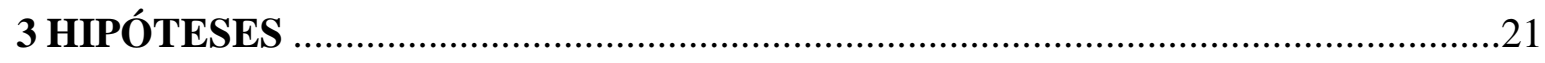

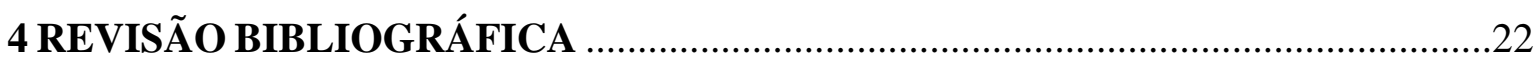

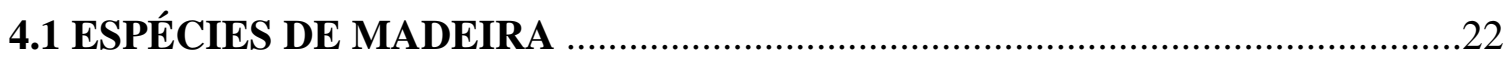

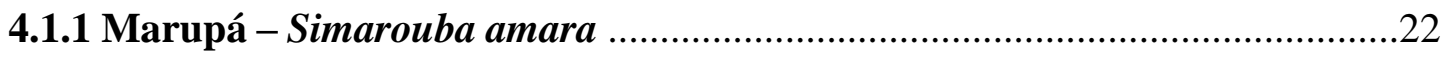

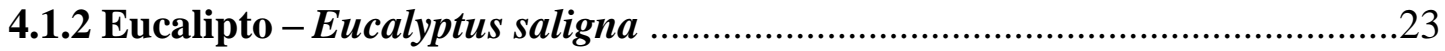

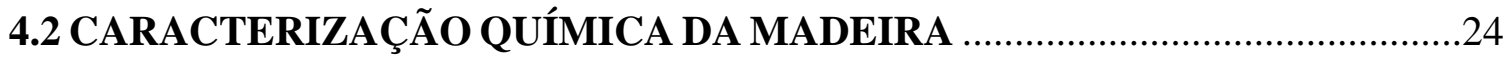

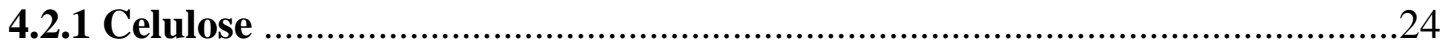

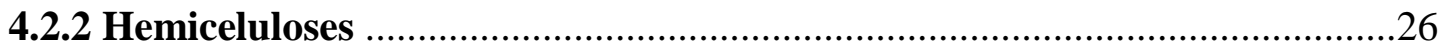

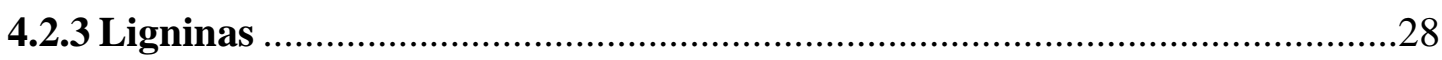

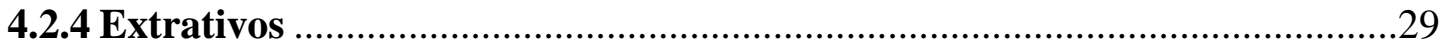

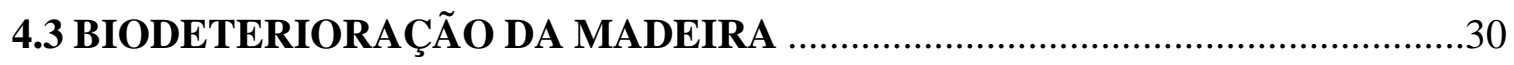

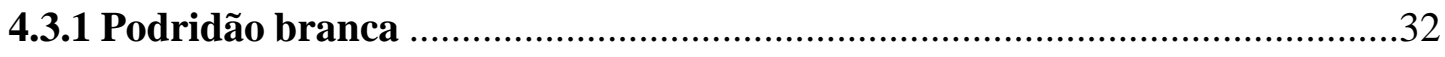

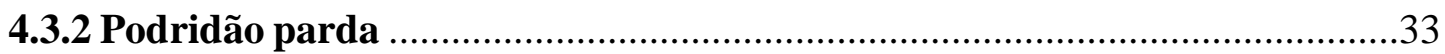

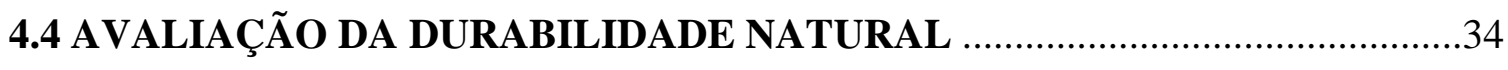

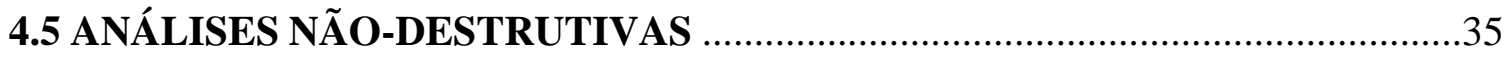

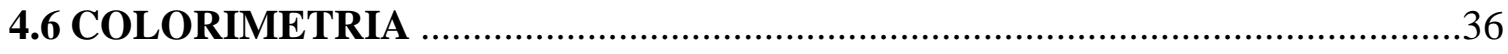

4.7 ESPECTROSCOPIA DE INFRAVERMELHO ............................................43

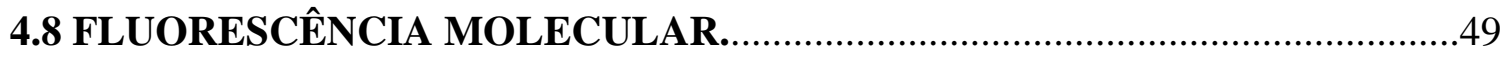

4.8.1 Fatores que influenciam na fluorescência …...............................................53

4.8.2 Instrumentos para medição de fluorescência ............................................54

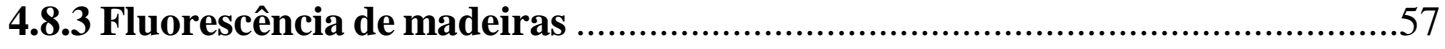

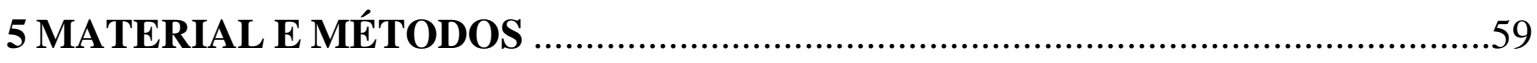

5.1 OBTENÇÃO DO MATERIAL E PREPARO DOS CORPOS DE PROVA ........59 


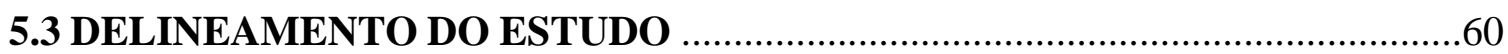

5.4 ENSAIO DE APODRECIMENTO ACELERADO ..........................................60

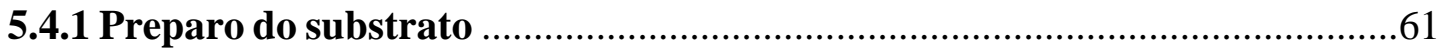

5.4.2 Repicagem dos fungos e inoculação dos frascos de vidro .............................61

5.4.3 Preparo dos corpos de prova para ensaio de apodrecimento acelerado .......63

5.4.4 Início do ensaio de apodrecimento acelerado...........................................63

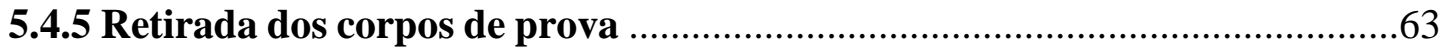

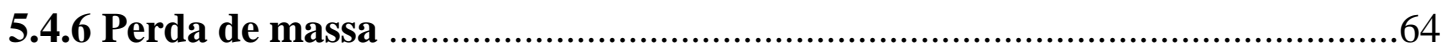

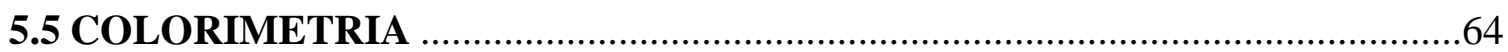

5.6. ESPECTROSCOPIA DE INFRAVERMELHO MÉDIO ..................................66

5.7 DETERMINAÇÃO DA FLUORESCÊNCIA MOLECULAR ............................70

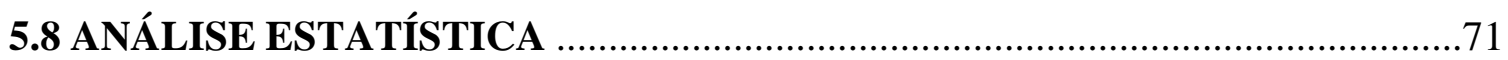

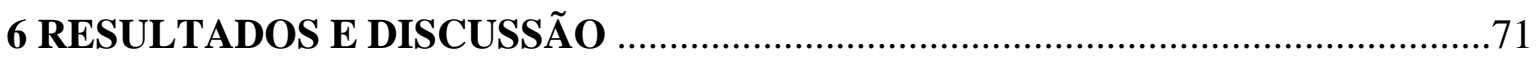

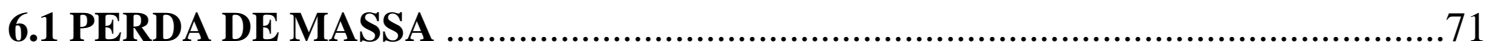

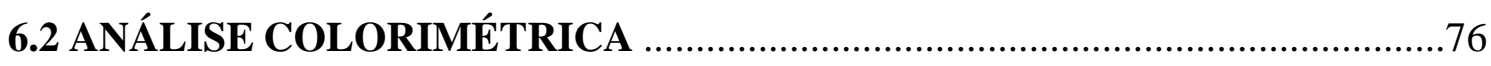

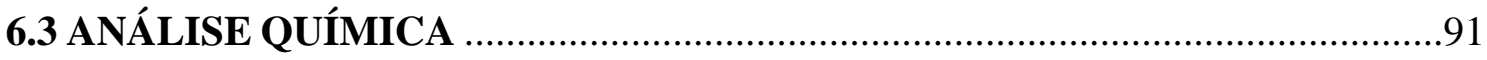

6.3.1 Espectroscopia de infravermelho médio.................................................91

6.3.2 Fluorescência molecular ................................................................... 102

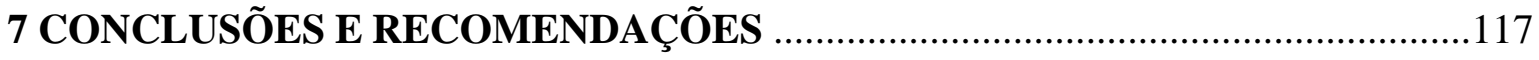

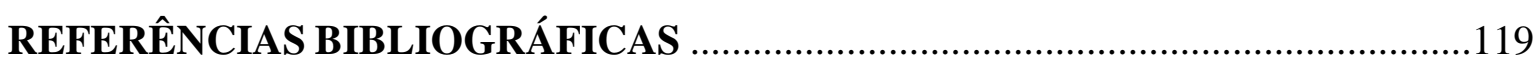

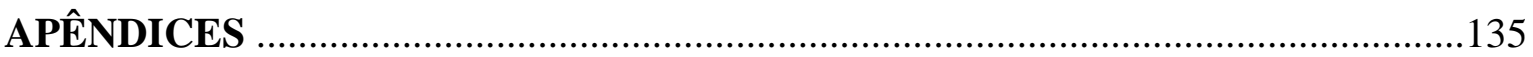




\section{LISTA DE TABELAS}

Tabela 4.1 Regiões do infravermelho. Fonte: SKOOG et al. (2002)

Tabela 5.1 Delineamento experimental

60

Tabela 6.1 Correlação entre a perda de massa e o período de exposição das madeiras aos fungos Gloeophyllum trabeum e Trametes versicolor.

Tabela 6.2 Correlação entre as alterações dos parâmetros colorimétricos da madeira de Simarouba amara e o período de ataque de podridão branca e parda.

Tabela 6.3 Correlação entre as alterações dos parâmetros colorimétricos da madeira de Eucalyptus saligna e o período de ataque de podridão branca e parda.

Tabela 6.4 Variação total da cor $(\Delta \mathrm{E})$ das madeiras de Simarouba amara e Eucalyptus saligna após exposição ao fungo Trametes versicolor.

Tabela 6.5 Variação total da cor $(\Delta \mathrm{E})$ das madeiras de Simarouba amara e Eucalyptus saligna após exposição ao fungo Gloeophyllum trabeum

Tabela 6.6 Correlação entre as alterações dos parâmetros colorimétricos da madeira de Simarouba amara e a perda de massa após ataque de podridão branca e parda. .88

Tabela 6.7 Correlação entre as alterações dos parâmetros colorimétricos da madeira de Eucalyptus saligna e a perda de massa após ataque de podridão branca e parda

Tabela 6.8 Alteração de intensidades das bandas selecionadas no infravermelho médio da madeira de Simarouba amara após exposição aos fungos apodrecedores .98

Tabela 6.9 Alteração de intensidades das bandas selecionadas no infravermelho médio da madeira de Eucalyptus saligna após exposição aos fungos apodrecedores . .98

Tabela 6.10 Correlação entre as alterações químicas, o período de exposição aos fungos e a perda de massa da madeira de Simarouba amara 101

Tabela 6.11 Correlação entre as alterações químicas, o período de exposição aos fungos e a perda de massa da madeira de Eucalyptus saligna .... .102

Tabela 6.12 Correlação entre a fluorescência emitida, o período de exposição aos fungos e a perda de massa da madeira de Simarouba amara .116 
Tabela 6.13 Correlação entre a fluorescência emitida, o período de exposição aos fungos e a perda de massa da madeira de Eucalyptus saligna .............................................................116 


\section{LISTA DE FIGURAS}

Figura 4.1 Estrutura parcial da molécula de celulose e da unidade de repetição celubiose.

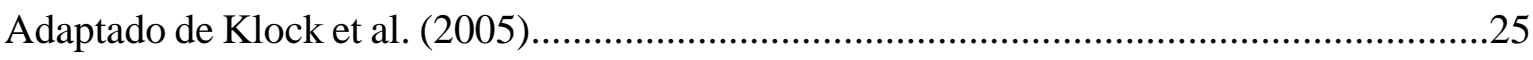

Figura 4.2 Componentes monoméricos da hemiceluloses. Fonte: Pastore (2004)................26

Figura 4.3 Precursores primários das ligninas. Fonte: Silva (2006).................................28

Figura 4.4 Estruturas de (1) quinona, (2) flavona, (3) lignana e (4) tanino. Fonte: Pastore (2004)

Figura 4.5 As cores e seus domínios. Fonte: Gouveia (2008) .37

Figura 4.6 Representação das cores no sistema CIELab. Fonte: Color Models (2011), adaptado por Stangerlin (2012).

Figura 4.7 Região do infravermelho relacionada com as outras regiões do espectro eletromagnético. Fonte: Pavia et al. (2012)

Figura 4.8 Tipos de vibrações moleculares: (a) Vibrações de estiramento e (b) Vibrações de deformação angular. Fonte: Holler et al. (2009).

Figura 4.9 Diagrama esquemático de espectrômetros com transformada de Fourier. Fonte:

Pavia et al. (2012) .48

Figura 4.10 Diagrama de Jablonski. Fonte: Skoog et al. (2002) .51

Figura 4.11 Câmara escura para visualização de fluorescência e amostras fluorescentes .....55

Figura 4.12 Esquema de funcionamento de um fluorímetro típico. Fonte: Holler et al. (2009).

Figura 4.13 Esquema de funcionamento de um espectrofluorímetro. Fonte: Moura (2013)..57

Figura 5.1 (a) Erlenmeyer contendo meio de cultura; (b) Processo de repicagem dos fungos.

Figura 5.2 Processo de inoculação dos frascos de vidro

Figura 5.3 Câmara climática no período de execução do projeto.

Figura 5.4 (a) Detalhe de corpo de prova ao ser retirado da câmara climática; (b) Processo de limpeza dos corpos de prova 
Figura 5.5 Espectrofotocolorímetro Color Eye-XTH-X-rite

Figura 5.6 Espectrofotômetro Tensor 37, Bruker

Figura 5.7 Dispositivo de reflectância difusa (DRIFT) .66

Figura 5.8 Dispositivo de reflectância total atenuada (ATR) .67

Figura 5.9 Espectros de ATR-MIR de madeira sólida (azul) e em pó (vermelho)

Figura 5.10 Espectros de DRIFT-MIR de madeira sólida (azul) e em pó (vermelho) 68

Figura 5.11 Espectros de DRIFT-MIR não manipulados

Figura 5.12 Espectro de DRIFT-MIR manipulado: fingerprint definido, alinhamento de base, seleção de bandas de interesse e definição de área para medição de bandas

Figura 5.13 Espectrofluorímetro Cary Eclipse, Varian .70

Figura 5.14 Dispositivo utilizado para análise de amostras sólidas. Fonte: Moura (2013) ...71

Figura 6.1 Perda de massa semanal da madeira de Simarouba amara após exposição aos fungos apodrecedores Trametes versicolor (podridão branca) e Gloeophyllum trabeum (podridão parda) .72

Figura 6.2 Perda de massa semanal da madeira de Eucalyptus saligna após exposição aos fungos apodrecedores Trametes versicolor (podridão branca) e Gloeophyllum trabeum (podridão parda)

Figura 6.3 Modelo estatístico gerado para predição da perda de massa da madeira de Simarouba amara em função do período de ataque dos fungos Trametes versicolor e Gloeophyllum trabeum .75

Figura 6.4 Modelo estatístico gerado para predição da perda de massa da madeira de Eucalyptus saligna em função do período de ataque dos fungos Trametes versicolor e Gloeophyllum trabeum .75

Figura 6.5 Alteração dos parâmetros colorimétricos da madeira de Simarouba amara após exposição aos fungos de podridão branca e parda, ao longo das 12 semanas

Figura 6.6 Alteração dos parâmetros colorimétricos da madeira de Eucalyptus saligna após exposição aos fungos de podridão branca e parda, ao longo das 12 semanas .79 
Figura 6.7 Curva de reflectância da madeira de Simarouba amara antes e após o ataque de podridão branca e parda

Figura 6.8 Curva de reflectância da madeira de Eucalyptus saligna antes e após o ataque de podridão branca e parda

Figura 6.9 Modelos estatísticos gerados para predição das alterações dos parâmetros colorimétricos L*, a*, b*, C e h* da madeira de Simarouba amara, em função do tempo de exposição aos fungos Trametes versicolor (TV) e Gloeophyllum trabeum (GT) .86

Figura 6.10 Modelos estatísticos gerados para predição das alterações dos parâmetros colorimétricos L*, a*, b*, C e h* da madeira de Eucalyptus saligna, em função do tempo de exposição aos fungos Trametes versicolor (TV) e Gloeophyllum trabeum (GT)

Figura 6.11 Espectros no infravermelho médio das madeiras sadias de Simarouba amara (azul) e Eucalyptus saligna (vermelho)

Figura 6.12 Seleção de bandas na região espectral de 1900 a $800 \mathrm{~cm}^{-1}$ para a madeira sadia de Simarouba amara .92

Figura 6.13 Seleção de bandas na região espectral de 1900 a $800 \mathrm{~cm}^{-1}$ para a madeira sadia de Eucalyptus saligna

Figura 6.14 Evolução dos espectros de infravermelho médio da madeira de Simarouba amara submetida ao fungo apodrecedor Trametes versicolor durante 12 semanas .94

Figura 6.15 Evolução dos espectros de infravermelho médio da madeira de Simarouba amara submetida ao fungo apodrecedor Gloeophyllum trabeum durante 12 semanas

Figura 6.16 Evolução dos espectros de infravermelho médio da madeira de Eucalyptus saligna submetida ao fungo apodrecedor Trametes versicolor durante 12 semanas .95

Figura 6.17 Evolução dos espectros de infravermelho médio da madeira de Eucalyptus saligna submetida ao fungo apodrecedor Gloeophyllum trabeum durante 12 semanas

Figura 6.18 Espectros no infravermelho médio da madeira Simarouba amara sadia (azul) e após ataque dos fungos de podridão branca Trametes versicolor (verde) e podridão parda Gloeophyllum trabeum (preto) . .96 
Figura 6.19 Espectros no infravermelho médio da madeira Eucalyptus saligna sadia (vermelho) e após ataque dos fungos de podridão branca Trametes versicolor (verde) e podridão parda Gloeophyllum trabeum (preto)

Figura 6.20 Espectros de emissão de fluorescência obtidos por excitação em $370 \mathrm{~nm}$ das amostras de Simarouba amara após 12 semanas de exposição ao fungo Trametes versicolor. 103

Figura 6.21 Espectros de emissão de fluorescência obtidos por excitação em $370 \mathrm{~nm}$ das amostras de Simarouba amara após 12 semanas de exposição ao fungo Gloeophyllum trabeum 103

Figura 6.22 Espectros de emissão de fluorescência obtidos por excitação em $370 \mathrm{~nm}$ das amostras de Eucalyptus saligna após 12 semanas de exposição ao fungo Trametes versicolor. 104

Figura 6.23 Espectros de emissão de fluorescência obtidos por excitação em $370 \mathrm{~nm}$ das amostras de Eucalyptus saligna após 12 semanas de exposição ao fungo Gloeophyllum trabeum 104

Figura 6.24 Dendrograma da madeira de Simarouba amara submetida aos fungos Trametes versicolor (2-13) e Gloeophyllum trabeum (14-25)

Figura 6.25 Dendrograma da madeira de Eucalyptus saligna submetida aos fungos Trametes versicolor (2-13) e Gloeophyllum trabeum (14-25) 106

Figura 6.26 Gráfico de escores obtido para a madeira de Simarouba amara após o ataque de Trametes versicolor (2-13) e Gloeophyllum trabeum (14-25) 107

Figura 6.27 Gráfico de escores relativos à componente 1 obtido para a madeira de Simarouba amara após o ataque de Trametes versicolor (2-13) e Gloeophyllum trabeum (14-25) ......108

Figura 6.28 Gráfico de escores obtido para a madeira de Eucalyptus saligna após o ataque de Trametes versicolor (2-13) e Gloeophyllum trabeum (14-25)

Figura 6.29 Gráfico de escores relativos à componente 1 obtido para a madeira de Simarouba amara após o ataque de Trametes versicolor (2-13) e Gloeophyllum trabeum (14-25) ......110

Figura 6.30 Gráfico de pesos das componentes 1, 2 e 3 referentes às amostras de Simarouba amara submetidas aos fungos apodrecedores 111 
Figura 6.31 Gráfico de pesos das componentes 1, 2 e 3 referentes às amostras de Eucalyptus saligna submetidas aos fungos apodrecedores 112

Figura 6.32 Espectros de emissão de fluorescência obtidos por excitação em $370 \mathrm{~nm}$ para a madeira de Simarouba amara sadia e após 12 semanas de ataque dos fungos Trametes versicolor (podridão branca) e Gloephyllum trabeum (podridão parda)

Figura 6.33 Espectros de emissão de fluorescência obtidos por excitação em $370 \mathrm{~nm}$ para a madeira de Eucalyptus saligna sadia e após 12 semanas de ataque dos fungos Trametes versicolor (podridão branca) e Gloephyllum trabeum (podridão parda) 115 


\section{LISTA DE SÍMBOLOS, NOMENCLATURA E ABREVIAÇÕES}

$\begin{array}{ll}\AA & \text { Ångström } \\ \mathrm{a}^{*} & \text { Parâmetro colorimétrico do eixo vermelho-verde } \\ \text { ABRAF } & \text { Associação Brasileira de Produtores de Florestas Plantadas } \\ \text { ASTM } & \text { American Society for Testing and Materials } \\ \text { atm } & \text { Atmosfera } \\ \text { ATR } & \text { Espectroscopia de reflectância total atenuada } \\ \mathrm{b}^{*} & \text { Parâmetro colorimétrico do eixo amarelo-azul } \\ \mathrm{C} & \text { Parâmetro colorimétrico de saturação ou cromaticidade } \\ \text { CIE } & \text { Comission Internacional de L'Eclairage } \\ \text { cm } & \text { Centímetro } \\ \text { DAP } & \text { Diâmetro à altura do peito }\end{array}$

DRIFT Espectrometria de reflectância difusa no infravermelho com transformada de Fourier

g Gramas

$\mathrm{g} / \mathrm{cm}^{3} \quad$ Gramas por centímetro cúbico

$\mathrm{g} / \mathrm{mol} \quad$ Gramas por mol

h* $\quad$ Ângulo de tinta

$\mathrm{Hz} \quad$ Hertz

Kg Quilogramas

L* Claridade ou luminosidade

m Metro

$\mathrm{mL} \quad$ Mililitro

nm Nanômetro

${ }^{\circ} \mathrm{C} \quad$ Graus Ceulsius

$\mathrm{OH} \quad$ Hidroxila

PLS-DA Partial Least Squares - Discriminant Analysis

PRNT Poder Relativo de Neutralização Total

s Segundo 
UV Radiação ultravioleta

W Watt

$\Delta \mathrm{a}^{*} \quad$ Variação do parâmetro colorimétrico $\mathrm{a}^{*}$

$\Delta \mathrm{b}^{*} \quad$ Variação do parâmetro colorimétrico b*

$\Delta \mathrm{E} \quad$ Variação total da cor

$\Delta \mathrm{L}^{*} \quad$ Variação da claridade ou luminosidade

$\mu \mathrm{m} \quad$ Micrômetro 


\section{INTRODUÇÃO}

A madeira é um material amplamente conhecido e empregado em diversas finalidades, que possui estrutura anatômica e composição química heterogêneas. A heterogeneidade química e anatômica influencia as propriedades físicas (cor, densidade, umidade e anisotropia), mecânicas (elasticidade, carga máxima de ruptura) e biológicas (classes dessemelhantes de resistência aos mais diversos organismos xilófagos) da madeira.

Por ser um material biológico, é susceptível ao ataque de organismos xilófagos, desde insetos (brocas e cupins) até microorganismos (bactérias e fungos). Visando a determinação de uso tecnológico, qualidade e maior durabilidade da madeira e de seus produtos fins, a propriedade de durabilidade natural têm sido objeto de estudos frequentes a nível nacional e internacional.

Nesse contexto, Kelley et al. (2002) destacam que a deterioração e a descoloração causadas por fungos são as maiores fontes de desvalorização na produção de madeira com perdas de 15 a $25 \%$ do valor da madeira em pé e de 10 a $15 \%$ de produtos de madeira durante a estocagem e utilização. Portanto, a ação destes organismos deterioradores de madeira, se não detectada a tempo, pode causar enormes prejuízos financeiros, seja pela substituição das peças levemente deterioradas ou até mesmo pela ruptura total da estrutura. Estudos mais práticos acerca da detecção precoce e discriminação do agente xilófago, utilizando equipamentos portáteis e precisos em inspeções de campo são metas futuras nesta área.

As tecnologias não destrutivas têm sido ferramentas bastante úteis na avaliação dos danos causados à madeira pelos fungos xilófagos. As principais vantagens de tais técnicas em relação às convencionais são a praticidade, rapidez e precisão dos resultados obtidos, principalmente quando empregados em campo. A espectroscopia vibracional no infravermelho e a colorimetria já são conhecidas e utilizadas, porém a espectrofluorimetria nunca foi utilizada para tais avaliações, necessitando de estudos exploratórios que possam indicar ou não esta técnica em estudos de laboratório e de campo. Estas novas tecnologias incrementam os resultados obtidos, dando uma maior confiabilidade a estes, uma vez que apenas os dados de perda de massa não são suficientes para fazer correlações seguras entre as alterações nas diversas propriedades da madeira ao longo do período de ataque do fungo.

Portanto, a partir de um estudo mais detalhado, semana a semana, é possível caracterizar de forma mais fiel as alterações sofridas pela madeira e, consequentemente, particularizar a sua resistência natural. 
Ressalta-se a importância de estudos relacionados à durabilidade natural da madeira, uma vez que são essenciais para o fornecimento de produtos finais de melhor qualidade, além de gerar informações quanto à sua utilização em situações de exposição a agentes biodeterioradores, evitando assim gastos desnecessários.

Além disso, outro fator a ser destacado é que a maioria dos estudos têm avaliado apenas períodos finais do ataque dos fungos, deixando um déficit de informações.

\section{OBJETIVOS}

\subsection{OBJETIVO GERAL}

Avaliar o desenvolvimento do ataque dos fungos apodrecedores nas madeiras de Simarouba amara (marupá) e de Eucalyptus saligna (eucalipto), utilizando técnicas não destrutivas, visando identificar o grau de integridade das mesmas, em termos de propriedades físicas e químicas.

\subsection{OBJETIVOS ESPECÍFICOS}

Avaliar o emprego da colorimetria, espectroscopia no infravermelho médio e fluorescência molecular, no monitoramento das alterações nos parâmetros colorimétricos $\left(\mathrm{L}^{*}, \mathrm{a}^{*}, \mathrm{~b}^{*}, \mathrm{C}\right.$ e $\mathrm{h}^{*}$ ) e químicos (holocelulose, lignina e fluorescência) das madeiras de marupá e de eucalipto, em diferentes estágios de ataque dos fungos Trametes versicolor (podridão branca) e Gloeophyllum trabeum (podridão parda).

Correlacionar as propriedades em estudo com a perda de massa decorrente da biodeterioração.

Ampliar a abordagem e o conhecimento de novas técnicas não destrutivas acerca de espécies de madeiras brasileiras.

\section{HIPÓTESES}

As técnicas não destrutivas de colorimetria, espectroscopia no infravermelho médio e fluorescência molecular são úteis para a detecção precoce e o monitoramento do ataque de fungos apodrecedores nas madeiras de marupá e eucalipto.

De acordo com o tipo de fungo apodrecedor, as madeiras de marupá e eucalipto apresentam comportamentos diferenciados em relação a sua perda de massa, cor, composição química (percentual de holocelulose e lignina) e fluorescência emitida. 


\section{REVISÃO BIBLIOGRÁFICA}

\subsection{ESPÉCIES DE MADEIRA}

\subsubsection{Marupá - Simarouba amara}

O marupá (Simarouba amara Aubl.), pertencente à família Simaroubaceae, ocorre nas Índias Ocidentais, na Amazônia e nos Estados da Bahia, Ceará e Pernambuco. A espécie habita matas de várzeas, onde é mais frequente e atinge maior porte, e é ocasional nas capoeiras e savanas de solo arenoso (RIZZINI, 1978; LOUREIRO, 1979).

Esta espécie é conhecida como caixeta, paraparaíba e marupaúba, entre outros nomes. Apresenta cerne e alburno indistintos, pela cor branco-palha levemente amarelada; grã direita, com textura média e brilho moderado; cheiro imperceptível e gosto levemente amargo; e baixa resistência ao corte (MARQUES, 1997).

É uma espécie pioneira, que dificilmente ultrapassa $30 \mathrm{~m}$ de altura, podendo alcançar até 80 $\mathrm{cm}$ de diâmetro. Apresenta fuste alto e muito cilíndrico e sua casca é superficialmente fissurada e corticosa, com ritidoma de coloração bege a pardo-acinzentado. A casca viva, após oxidação, adquire a cor amarela queimado e apresenta gosto muito amargo. Floresce de agosto a setembro e frutifica de novembro a dezembro. Esta espécie é de rápido crescimento podendo ser empregada em programas de reflorestamento nas regiões de sua distribuição natural (CRUZ et al., 2006).

Sua madeira é leve e de elevada porosidade, ou seja, de baixa massa específica, próxima a $0,37 \mathrm{~g} / \mathrm{cm}^{3}$ (SOUZA et al., 2002) e apresenta baixa resistência mecânica (CRUZ et al., 2006). Loureiro (1979) destacou a sua boa trabalhabilidade e Jankowski et al. (1990) afirmaram que esta espécie não é refratária à secagem ao ar livre e em secadores convencionais.

Segundo Santana e Okino (2007), o marupá apresenta em sua composição química 48,5\% de celulose, $32 \%$ de lignina, $19,5 \%$ de hemiceluloses, $2,1 \%$ de extrativos e $0,3 \%$ de cinzas.

Com relação à durabilidade natural, é susceptível ao ataque de fungos xilófagos, brocas marinhas e cupins (PAULA; ALVES, 2007; COSTA, 2009; MARCONDES, 2011; STANGERLIN, 2012).

O seu uso é indicado em caixotaria para produtos leves, na fabricação de instrumentos musicais, em pequenos objetos de madeira (POM), em revestimentos internos (forros e lambris), além disso apresenta uso potencial na indústria de painéis laminados e de celulose e papel (STANGERLIN, 2012). 


\subsubsection{Eucalipto - Eucalyptus saligna}

Eucalyptus saligna, vulgarmente conhecido como eucalipto, pertencente à família Myrtaceae, é uma espécie originária da Austrália. Assemelha-se bastante ao Eucalyptus grandis, em aspectos botânicos, ecológicos e silviculturais (ALZATE, 2004).

Ocorre desde altitudes próximas ao nível do mar no Sul da Austrália até $1.100 \mathrm{~m}$ de altitude em áreas do Norte $\left(21^{\circ} \mathrm{S}\right)$, sob climas temperados a subtropicais, isoladamente e/ou em associação com Eucalyptus grandis. A espécie é freqüentemente confundida com Eucalyptus grandis, porém, produz madeira de maior densidade e apresenta menor susceptibilidade à deficiência do elemento mineral boro (MARCÓ, 2005).

No Brasil, esta espécie é encontrada na Bahia, Tocantins, Mato Grosso, Mato Grosso do Sul, Minas Gerais, São Paulo, Paraná, Rio Grande do Sul, Santa Catarina e outros. É também encontrada em outros países, como África do Sul, Chile, Congo, Nigéria, Quênia, Zaire e Nova Zelândia (IPT, s.d.).

Esta espécie é bastante versátil e recomendada para usos múltiplos, adaptando-se a solos hidromórficos ou arenosos, em diferentes altitudes. É apta para regiões sem ocorrência de geadas e situações de déficit hídrico severos, é tolerante ao fogo baixo e possui alta capacidade de regeneração por brotação (ALZATE, 2004).

É uma espécie de elevada produtividade e facilidade na obtenção de material clonal, devido a seu fácil enraizamento (PISSININ, 2013). Apresenta cerne e alburno distintos pela cor, cerne avermelhado ou castanho avermelhado claro, cheiro e gosto imperceptíveis, densidade mediana, grã direita, textura média. Além disso, é uma madeira de fácil trabalhabilidade em operações de usinagem (torneamento, furação e lixamento) e apresenta bom acabamento. É uma madeira de baixa estabilidade dimensional e a sua secagem é rápida, com a ocorrência de rachaduras e empenamentos (IPT, 1989; ALZATE, 2004).

Trugilho et al. (1996) ao avaliarem a madeira juvenil de Eucalyptus saligna encontraram densidades básicas de até $0,52 \mathrm{~g} / \mathrm{cm}^{3}$. Pereira et al. (2000) relataram valores de densidade básica de $0,44 \mathrm{~g} / \mathrm{cm}^{3}, 0,53 \mathrm{~g} / \mathrm{cm}^{3}$ e $0,55 \mathrm{~g} / \mathrm{cm}^{3}$ para plantios de Eucalyptus saligna nas idades de 9,8 e 10,5 anos respectivamente.

Quanto à durabilidade natural, o seu cerne apresenta moderada a baixa resistência aos organismos xilófagos (IPT, 1989). 


\subsection{CARACTERIZAÇÃO QUÍMICA DA MADEIRA}

A madeira é considerada um material heterogêneo, possuindo diferentes tipos de células, adaptadas a desempenharem funções específicas. As variações nas composições químicas, físicas e anatômicas da madeira são grandes entre espécies, embora dentro da mesma espécie elas também ocorram, em função principalmente da idade, fatores genéticos e ambientais. Dentro de uma mesma espécie, ocorrem variações significativas ao longo do tronco e na direção da medula até a casca (TRUGILHO et al., 1996).

Essa variação da composição química e da organização dos componentes de alto e baixo peso molecular na ultraestrutura da madeira justifica, portanto, a diversidade das propriedades tecnológicas (morfológicas, físicas, mecânicas e biológicas) (PALA, 2007).

A madeira também pode ser definida como um biopolímero tridimensional formado por componentes de alto peso molecular, constituintes da parede celular (celulose, hemiceluloses e lignina), e em menor quantidade, os compostos de baixo peso molecular (extrativos) (ROWELL et al., 2005).

$\mathrm{Na}$ parede celular, celulose, polioses e lignina estão intimamente associadas e/ou ligadas quimicamente, formando diferentes camadas. A parede primária $(\mathrm{P})$ é formada por microfibrilas de celulose e hemiceluloses, e a parede secundária (S) é composta principalmente por celulose e lignina. As diferentes células encontram-se separadas pela lamela média (LM), rica em lignina (FENGEL; WEGENER, 1989).

No âmbito intramolecular, a composição química elementar das espécies de madeira tanto coníferas como folhosas não difere consideravelmente, sendo que os principais elementos encontrados são Carbono (C), Hidrogênio $(H)$, Oxigênio $(\mathrm{O})$ e em quantidades menores Nitrogênio $(\mathrm{N})$. Além desses elementos encontram-se pequenas quantidades de Cálcio $(\mathrm{Ca})$, Potássio (K), Magnésio (Mg) e outros (KLOCK et al., 2005).

Para Trugilho et al. (1997), é importante o conhecimento da composição química da madeira para utilizações técnicas e fins científicos, como em processos de polpação e branqueamento, produção de carvão, produção de estruturas de madeira e desenvolvimento de retardantes de fogo e preservantes para aumentar a durabilidade da madeira.

\subsubsection{Celulose}

A celulose é o principal polímero constituinte da madeira e apresenta-se em quantidades que variam em torno de 40 a $50 \%$ da composição total. Celulose é um polissacarídeo de cadeia 
linear com comprimento suficiente para ser insolúvel em solventes orgânicos, água, ácidos e álcalis diluídos, à temperatura ambiente, consistindo única e exclusivamente de unidades de $\beta$ - D - anidroglucopiranose, ligadas entre si através de uma ligação glicosídica entre os carbonos 1 e 4, possuindo uma estrutura organizada e parcialmente cristalina (KLOCK et al., 2005). A ligação $\beta(1 \rightarrow 4)$ envolve a eliminação de uma molécula de água, explicando o prefixo anidro (FENGEL; WEGENER, 1984).

Devido à configuração espacial alternante da ligação glicosídica unindo resíduos adjacentes de glicose, a unidade de repetição da celulose é considerada a celobiose (Figura 4.1), um dissacarídeo de D-glicose com ligações $\beta(1 \rightarrow 4)$ (TAIZ; ZEIGER, 2009).

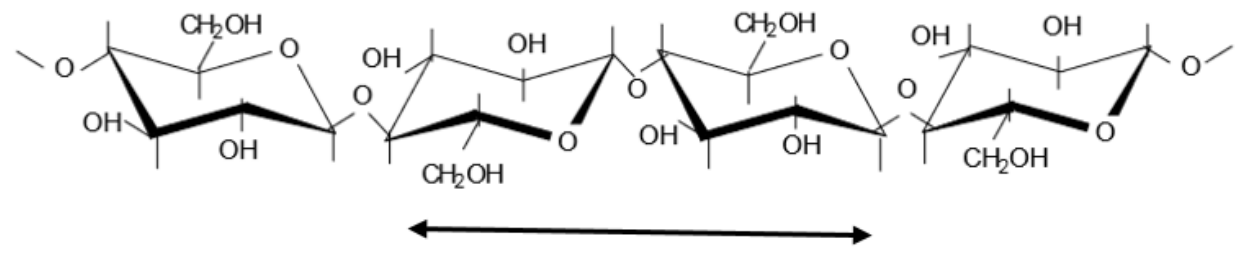

Celobiose

Figura 4.1 Estrutura parcial da molécula de celulose e da unidade de repetição celobiose. Adaptado de Klock et al. (2005).

De acordo com Rowell (2005), o número de unidades de anidroglucopiranose presente na molécula de celulose é variável em função da espécie florestal, da localização na parede celular e do método de isolamento da celulose. No entanto pode-se considerar que em média, para celulose nativa, o grau de polimerização é entre 9.000-10.000, podendo alcançar valores de 15.000 .

Segundo Penedo (1980), a celulose é um polímero de alto peso molecular (300.000 a 500.000 $\mathrm{g} / \mathrm{mol}$ ) e as cadeias de celulose nas paredes celulares dos vegetais são arranjadas compactamente, devido ao número de ligações de hidrogênio em sua estrutura.

Moléculas de celulose são completamente lineares e tem forte tendência para formar pontes de hidrogênio intermoleculares (entre grupos $\mathrm{OH}$ de moléculas adjacentes de celulose) e intramoleculares (entre grupos $\mathrm{OH}$ de unidades glicosídicas adjacentes da mesma molécula de celulose), conferindo coesão entre as cadeias e rigidez à cadeia celulósica, respectivamente (KLOCK et al., 2005). 
Feixes de moléculas de celulose se agregam na forma de microfibrilas na qual regiões altamente ordenadas (cristalinas) se alternam com regiões menos ordenadas (amorfas). As microfibrilas constroem fibrilas e estas constroem as fibras celulósicas (KLOCK et al., 2005). Portanto, as microfibrilas de celulose são estruturas relativamente rígidas que contribuem para a resistência e a disposição estrutural da parede celular (TAIZ; ZEIGER, 2009). Além disso, Sjoström (1993) cita que a alta resistência mecânica à tração e a alta insolubilidade à grande parte dos solventes orgânicos são proporcionadas pela estrutura fibrosa formada pela celulose.

As microfibrilas de celulose são de comprimento indeterminado e variam consideravelmente em largura e grau de ordem, dependendo da fonte. As microfibrilas de celulose em plantas terrestres, por exemplo, possuem 2 a $5 \mathrm{~nm}$ de largura, enquanto aquelas formadas por algas podem ter acima de $20 \mathrm{~nm}$ de largura e ordenação mais alta (mais cristalina) que as encontradas em plantas terrestres (STURCOVA et al., 2004).

\subsubsection{Hemiceluloses}

As hemiceluloses, ou polioses, constituem um grupo heterogêneo de polissacararídeos que caracteristicamente ligam-se à superfície da celulose (TAIZ; ZEIGER, 2009). Enquanto a celulose, como substância química, contém exclusivamente a D-glucose como unidade fundamental, as polioses são polímeros, em cuja composição podem aparecer, condensados em proporções variadas, as seguintes unidades de açúcar (Figura 4.2): xilose, manose, glucose, arabinose, galactose, ácido galactourônico, ácido glucourônico e ácido metilglucourônico (KLOCK et al., 2005).
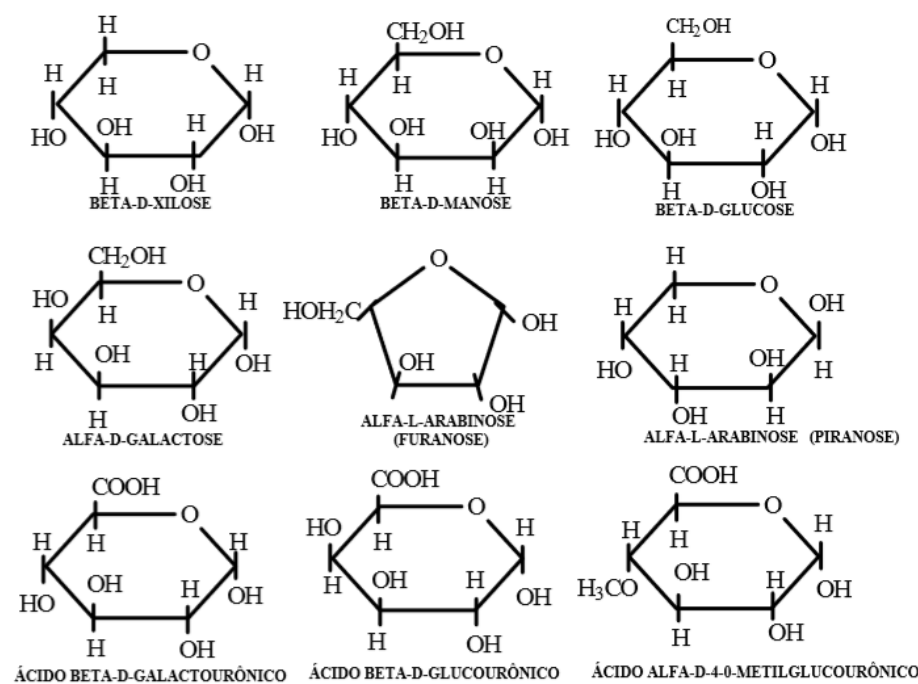

Figura 4.2 Componentes monoméricos das hemiceluloses. Fonte: Pastore (2004). 
Diversos tipos de hemiceluloses são encontrados em paredes celulares. Portanto, as paredes de tecidos e espécies distintas variam quanto à sua composição em hemiceluloses (TAIZ; ZEIGER, 2009).

As hemiceluloses constituem entre 15 a $35 \%$ da madeira de folhosas e 20 a $32 \%$ das madeiras de coníferas (ROWELL, 2005). Contribuem para as propriedades estruturais na parede celular e desempenham funções na regulação do crescimento e desenvolvimento das plantas (LIMA, 2002).

A cadeia principal de uma poliose pode-se consistir de uma só unidade (homopolímero), como a xilana, ou de duas ou mais unidades (heteropolímero), como a glucomanana (PASTORE, 2004). Em geral, enquanto as madeiras de folhosas são compostas principalmente por heteroxilanas altamente acetiladas, as madeiras de coníferas apresentam uma elevada proporção de glucomananas e galactoglucomananas parcialmente acetiladas (RAMOS, 2003).

Estas polioses podem formar correntes que reúnem microfibrilas de celulose em uma rede coesa ou também podem funcionar como um revestimento escorregadio para impedir o contato direto microfibrila-microfibrila (TAIZ; ZEIGER, 2009). Elas estão ligadas à celulose através de grande quantidade de ligações de hidrogênio e seus acoplamentos físicos tornam quase impossível separá-las, sem danos à celulose (COLODETTE, 2005).

As hemiceluloses são caracterizadas pelo baixo peso molecular, baixa cristalinidade (natureza amorfa), ramificação de suas cadeias poliméricas, baixa estabilidade dos monômeros (xilose, galactose, manose, arabinose e raminose), presença de grupos acetilas e solubilidade em álcali forte. Além disso, são os constituintes mais hidrófilos da madeira, contribuindo para sua variação dimensional e apresentam apenas a metade do poder calorífico da lignina. São compostos menos estáveis que a celulose e a lignina e apresentam cadeias mais curtas que a celulose (PANSHIN; ZEEUW, 1970; SJOSTROM; ALÉN, 1999; BORGES; QUIRINO, 2004; PASTORE, 2004; TAIZ; ZEIGER, 2009; LONGUE JÚNIOR; COLODETTE, 2011). São considerados os componentes mais reativos da parede celular, pois elas degradam em baixas temperaturas, entre 160 e $220^{\circ} \mathrm{C}$, devido à sua baixa massa molecular (PONCKSÁC et al., 2006).

Estão diretamente relacionadas a algumas propriedades da madeira, tais como resistência e elasticidade da madeira. 


\subsubsection{Ligninas}

As ligninas são moléculas, amorfas, tridimensionais, altamente complexas, cujo polímero é formado principalmente por unidades aromáticas de fenilpropano, que é considerada uma substância incrustante (ROWELL et al., 2005). Não ocorrem sozinhas na natureza e é impossível removê-las quantitativamente da estrutura da madeira sem considerável degradação (KLOCK et al., 2005).

Estão localizadas na lamela média composta, bem como na parede secundária. Durante o desenvolvimento das células, as ligninas são incorporadas como o último componente na parede, interpenetrando as fibrilas e assim fortalecendo, enrijecendo as paredes celulares (KLOCK et al., 2005).

De acordo com Klock et al. (2005), as ligninas têm sua origem a partir da polimerização dehidrogenativa (iniciada por enzimas) dos seguintes precursores primários: álcool transconiferílico, álcool trans-sinapílico e álcool para-trans-cumárico (Figura 4.3).

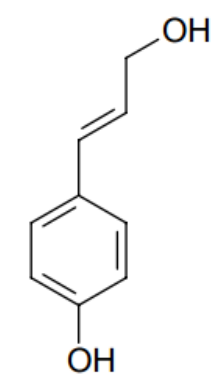

Álcool p-cumarílico

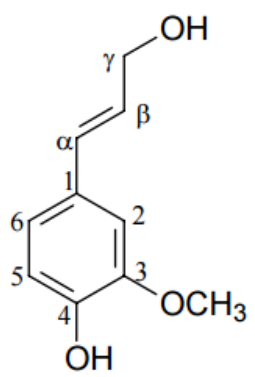

Álcool coniferílico

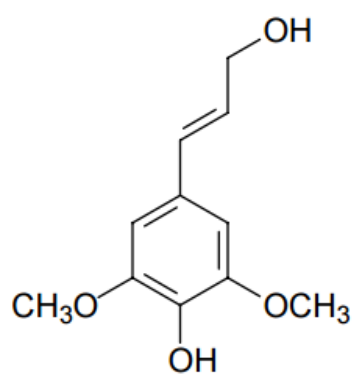

Álcool sinapílico

Figura 4.3 Precursores primários das ligninas. Fonte: Silva (2006).

As madeiras de folhosas contêm dois deles, o álcool coniferil (50-75\%) e o álcool sinapil (25-50\%), e as coníferas contêm somente o álcool coniferil. A polimerização do álcool coniferil produz ligninas guaiacil, enquanto que a polimerização dos álcoois coumaril e sinapil produzem as ligninas siringil-guaiacil das folhosas (PASTORE, 2004).

Em contraste com a celulose, que é formada por todas as plantas, a formação de ligninas só ocorre em plantas vasculares que desenvolvem tecidos especializados em funções tais como transporte de soluções aquosas e suporte mecânico. As plantas primitivas tais como fungos e algas não possuem ligninas aparentemente porque os seus aglomerados de células não diferenciadas não requerem a ação protetora e de suporte oferecida por este composto químico (KLOCK et al., 2005). 
As ligninas são componentes estruturais, incrementando as propriedades de elasticidade e resistência da madeira. A lignificação ocorre como uma consequência não somente do desenvolvimento do sistema de condução de água, mas também como uma necessidade da árvore para suportar sua copa a muitos metros de altura (KLOCK et al., 2005).

Assim como as polioses, as ligninas apresentam baixo grau de polimerização, quando comparado a celulose, sendo esse entre 5 a 130, dependendo da espécie vegetal e do grau de deterioração da molécula durante seu isolamento (STANGERLIN, 2012).

Sua estrutura tridimensional proporciona à parede celular rigidez e resistência às forças de compressão, gerando uma estrutura resistente ao impacto, compressão e quebra. Além disso, age como um agente permanente de ligação entre as células. Estão sempre associadas com as hemiceluloses na parede celular, não só através de interação física, como também de ligações covalentes (PHILIPP, 1988).

\subsubsection{Extrativos}

Os extrativos são compostos químicos formados a partir de graxas, ácidos graxos, álcoois graxos, fenóis, terpenos, esteroides, resinas ácidas, resinas, ceras e outros tipos de compostos orgânicos. Em geral, as madeiras de coníferas contêm mais extrativos que as madeiras de folhosas (ROWELL et al., 2005).

Estão localizados nas células do parênquima, nos canais secretores, na lamela média, nos espaços intercelulares e na parede celular, porém, não fazem parte dos componentes estruturais da parede celular. E, portanto, podem ser removidos da madeira através de solventes, sem afetar as propriedades mecânicas da madeira (FENGEL; WEGENER, 1989).

Os extrativos são frequentemente responsáveis por determinadas características da madeira como: cor, cheiro, resistência natural ao apodrecimento, gosto e propriedades abrasivas. Sua composição e quantidade relativa dependem de diversos fatores, como espécie, idade e região de procedência, dentre outros. Aproximadamente de 3-10\% da madeira seca é constituída de extrativos sendo que, geralmente para as madeiras de coníferas esse teor fica na faixa de 5-8\% e para as folhosas de regiões temperadas na faixa de $2-4 \%$, podendo chegar a valores superiores a 10\% na madeira de espécies de regiões tropicais (KLOCK et al., 2005).

Assim como os outros componentes principais, sua composição e quantidade pode variar não somente com o gênero e a espécie, mas também dentro da espécie, de árvore para árvore ou mesmo dentro da própria árvore com a posição no tronco. Em coníferas e folhosas, a 
maioria dos extrativos, desconsiderando-se a casca, se localiza no cerne (ROWELL et al., 2005).

Devido às proporções variadas encontradas em diferentes espécies, determinadas madeiras podem ser caracterizadas pela natureza e quantidade de componentes de baixo peso molecular ou acidentais (KLOCK et al., 2005).

De acordo com Lepage (1986), os principais extrativos que mudam a cor da madeira são: quinonas, flavonóides, lignanas e taninos (Figura 4.4). Os extrativos são de fundamental importância para indicação de uso final da madeira, incrementando o valor estético ou possibilitando uma maior durabilidade natural da madeira.
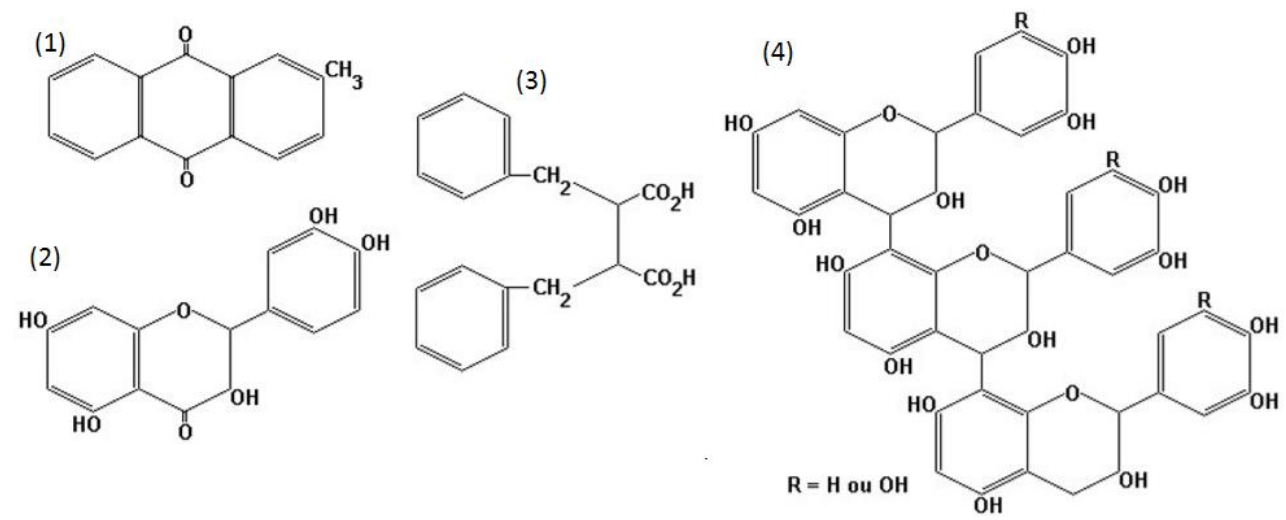

Figura 4.4 Estruturas de (1) quinona, (2) flavona, (3) lignana e (4) tanino. Fonte: Pastore (2004).

\subsection{BIODETERIORAÇÃO DA MADEIRA}

A madeira é um material versátil, com propriedades físicas, químicas e mecânicas que permitem sua utilização desde a fabricação de móveis e instrumentos musicais até sua inclusão em projetos arquitetônicos e de engenharia. Porém, por ser um material biológico, pode ser deteriorada por agentes biológicos, físicos, reações químicas e desgastes mecânicos (MORESCHI, 2013).

A deterioração biológica é causada por organismos xilófagos divididos em dois grupos: fungos e bactérias, que liberam enzimas que deterioram a madeira; e insetos e perfuradores marinhos, que escavam a estrutura da madeira (MENDES; ALVES, 1988).

Os agentes biológicos deterioram a madeira para utilizar os seus constituintes como fonte de energia, bem como para abrigo. Dentre eles, os fungos são responsáveis pela maior 
proporção de danos causados à madeira, pois ocorrem com maior frequência neste tipo de material (MORESCHI, 2013).

Mendes e Alves (1988) destacam que, além do substrato madeira, as condições ambientais afetam diretamente o desenvolvimento dos fungos. Para a maioria dos fungos xilófagos, a temperatura ideal varia entre $25^{\circ}$ a $30^{\circ} \mathrm{C}$, podendo acontecer também a temperaturas de $0^{\circ}$ a $40^{\circ} \mathrm{C}$. Com relação à umidade, valores acima de $20 \%$ são ideais. Os fungos xilófagos podem se desenvolver na madeira mesmo que esta apresente concentração de oxigênio inferior a $20 \%$ encontrado no ar, porém a ausência ou presença em concentrações muito baixas restringem o desenvolvimento. $\mathrm{O}$ pH ótimo situa-se entre 4,5 e 5,5, sendo o valor mínimo igual a 2,0 e o máximo pouco acima de 7,0.

Numa abordagem mais específica acerca da biodeterioração por fungos, destacam-se os Basidiomicetos, que são considerados os principais deterioradores. Os danos causados por estes fungos ocorrem necessariamente de forma extracelular, uma vez que os componentes da madeira devem ser inicialmente despolimerizados até compostos menores que são susceptíveis ao transporte através da parede celular. Estes fungos agem através da penetração de suas hifas pelo lúmen das células, as quais ali instaladas produzem uma variedade de metabólitos extracelulares que vão, assim, atuar deteriorando os componentes da parede celular vegetal (ARANTES; MILAGRES, 2009).

Os metabólitos extracelulares produzidos durante o processo de deterioração da parede celular também dependem do tipo de fungo atuante. As enzimas responsáveis pela deterioração da celulose e das polioses são hidrolases, que apresentam certa especificidade pelo respectivo substrato, enquanto que as enzimas envolvidas na deterioração da lignina são oxidases, que geralmente são pouco específicas (ARANTES; MILAGRES, 2009).

Dependendo do tipo de fungo, o ataque promoverá diferentes mudanças químicas, físicas e morfológicas na madeira, podendo também variar o grau de deterioração durante o mesmo período de exposição aos fungos. Assim, segundo Oliveira et al. (2005), uma das principais propriedades das madeiras é a sua maior ou menor suscetibilidade em ser atacada por organismos xilófagos. Madeiras que apresentam elevada durabilidade natural a esses organismos podem ser destacadas por um alto grau de nobreza, conferindo-lhes um amplo espectro de utilização e, consequentemente, tornando-as mais valorizadas no mercado.

De acordo com Santos (1992), a madeira sob ataque de fungos apresenta alterações na composição química, redução da resistência mecânica, diminuição de massa, modificação 
da cor natural, aumento da permeabilidade, redução da capacidade acústica, aumento da inflamabilidade, diminuição do poder calorífico e maior propensão ao ataque de insetos, comprometendo, dessa forma, a sua qualidade e inviabilizando a sua utilização para fins tecnológicos.

O processo de biodeterioração ocorre em etapas ou estágios graduais e contínuos e que dependem do tipo de microrganismo que está se desenvolvendo na madeira. O primeiro estágio, chamado de incipiente, tem início quando o microorganismo penetra superficialmente na madeira e começa a sua colonização liberando enzimas. Geralmente, neste estágio não ocorrem evidências macroscópicas da infecção. A deterioração vai se desenvolvendo e quando alguns sinais da infecção já podem ser notados, esta etapa é caracterizada como recente. Na seguinte, chamada de intermediária, mudanças na coloração e na textura da madeira já são bastante evidentes, mas a sua estrutura ainda permanece intacta. No último estágio, conhecido como avançado, a madeira torna-se completamente desestruturada. As etapas gerais de deterioração são semelhantes para diversos microorganismos, porém o padrão de deterioração é variável (ZABEL; MORRELL, 1992).

Em função das preferências alimentares e do desenvolvimento do ataque, os fungos podem ser classificados como manchadores, emboloradores e apodrecedores, deteriorando a madeira apenas superficialmente ou atingindo níveis mais internos da peça analisada.

Oliveira et al. (2005) ressaltam que os fungos responsáveis pela podridão parda e podridão branca possuem características enzimáticas próprias quanto à deterioração dos constituintes primários da madeira.

\subsubsection{Podridão branca}

Os fungos causadores da podridão branca pertencem à classe dos Basidiomicetos, e, raramente, à classe dos Ascomicetos (ROWELL, 2005). A característica comum de todos os fungos de podridão branca é a capacidade de deteriorar a lignina, assim como celulose e polioses. Entretanto, as velocidades relativas de deterioração da lignina e polissacarídeos variam significativamente de acordo com a espécie fúngica (ARANTES; MILAGRES, 2009).

Macroscopicamente, a madeira atacada por fungos causadores de podridão branca perde o seu aspecto lustroso e sua cor natural, tornando-se esbranquiçada, como resultado da destruição de seus pigmentos. Podem ser observadas linhas escuras demarcando o limite 
entre as regiões atacada e não atacada, uma consistência esponjosa, além de uma progressiva perda de massa e de resistência da madeira, pelo contínuo consumo da celulose, da hemicelulose e da lignina (MORESCHI, 2013).

No âmbito microscópico, os fungos de podridão branca podem ser diferenciados pela forma de ataque erosiva ou não erosiva à parede celular vegetal. $\mathrm{O}$ ataque erosivo caracteriza-se pela remoção simultânea de celulose, hemicelulose e lignina. Já o ataque não erosivo caracteriza-se pela manutenção da celulose à custa da deterioração de hemicelulose e lignina (KIRK; CULLEN, 1998).

O fungo de podridão branca Trametes versicolor é um dos mais conhecidos e estudados na avaliação da resistência natural da madeira. Segundo Rowell (2005), ele ocorre predominantemente em madeira serrada de folhosas. Além disso, caracteriza-se por promover um ataque erosivo à parede celular, deteriorando simultaneamente a lignina, celulose e hemiceluloses (TANAKA et al., 1999).

\subsubsection{Podridão parda}

Os fungos causadores da podridão parda pertencem à classe dos Basidiomicetos (MORESCHI, 2013). Estes fungos deterioram a celulose e as hemiceluloses, transformando-as em substâncias solúveis facilmente assimiladas e digeridas. A lignina, de coloração escura, fica praticamente intacta (MENDES; ALVES, 1988).

Macroscopicamente, a madeira atacada por fungos de podridão parda apresenta o aspecto de estar levemente queimada, coloração parda, apresentando inúmeras rachaduras perpendiculares e ao longo da direção das fibras, além de colapsar com facilidade (LEPAGE, 1986).

Microscopicamente, não ocorre deterioração da célula na direção lume-lamela média como na podridão branca, uma vez que a lignina residual mantém a estrutura da célula. A hifa do fungo, que se encontra no lúmen, secreta enzimas que se difundem através da parede celular, destruindo os carboidratos. A continuidade do processo leva ao ponto onde a lignina residual não consegue mais suportar as forças às quais a célula está sujeita, ocorrendo, assim, o colapso da parede celular (LEPAGE, 1986).

A destruição dos elementos estruturais que se encontram nas paredes celulares provoca uma rápida perda da resistência mecânica da madeira, levando ao colapso da estrutura, e uma proporcional perda de massa (MENDES; ALVES, 1988; MORESCHI, 2013). Essa perda de 
resistência mecânica ocorre mais rapidamente quando comparada a fungos de podridão branca (LEPAGE, 1986).

O fungo de podridão parda Gloeophyllum trabeum também é bastante conhecido e ocorre predominantemente em madeira serrada de coníferas (ROWELL, 2005).

\subsection{AVALIAÇÃO DA DURABILIDADE NATURAL}

Segundo Paes (2002), a resistência da madeira à deterioração é a capacidade inerente à espécie de resistir à ação de agentes deterioradores, incluindo os agentes biológicos, físicos e químicos. Porém, Oliveira et al. (2005) afirmam que nenhuma espécie de madeira, nem mesmo aquelas de reconhecida durabilidade natural, são capazes de resistir, indefinidamente, às intempéries, variações das condições ambientais, ataque de microrganismos e ação do próprio homem.

Enquanto as madeiras de gimnospermas são naturalmente suscetíveis aos processos de biodeterioração, as de angiospermas apresentam vários graus de resistência natural ao ataque biológico. O alburno é mais suscetível à deterioração do que o cerne por ser a parte da madeira que apresenta material nutritivo armazenado. Já o cerne, além de não conter material de reserva, possui extrativos, que contêm substâncias inibidoras ou tóxicas (SILVA, 2007). Para Botelho et al. (2000), essa característica varia significativamente entre espécies e dentro da mesma árvore.

Nesse contexto, o conhecimento da resistência natural da madeira é de suma importância para a recomendação de seu emprego mais adequado, evitando-se gastos desnecessários com a reposição de peças, reduzindo os impactos sobre as florestas remanescentes (PAES et al., 2004).

Para avaliar o grau de durabilidade natural da madeira, podem ser feitos ensaios de campo ou ensaios de laboratório.

Testes em campo reproduzem com fidelidade situações de uso da madeira com ou sem tratamento químico. Madeiras nestas situações estão expostas a períodos irregulares de lixiviação, secagem, exposição à luz solar, além dos agentes químicos presentes no solo e diversos microrganismos xilófagos que podem atuar em conjunto. Ensaios em campo são os mais comumente utilizados para avaliação da resistência da madeira e da eficiência de produtos preservativos, bem como de diferentes processos de impregnação. Consistem basicamente no soterramento parcial de amostras de madeira seguidos de inspeções 
periódicas, objetivando avaliar o seu estado de sanidade, sendo que após um determinado período de tempo, em geral anos, a vida útil da madeira em serviço é determinada (COSTA et al., 2005). Porém, segundo JESUS et al. (1998), a desvantagem desta metodologia é a obtenção dos dados a longo prazo, ou seja, entre 10 e 20 anos.

Ensaios de resistência natural em laboratório consistem na exposição de corpos de prova, provenientes do cerne, à fungos xilófagos ou térmitas, durante um determinado período de tempo estabelecido por normas específicas. Após o período de ataque, é determinada a perda de massa da madeira e a sua classificação de acordo com as classes de resistência da norma seguida.

\subsection{ANÁLISES NÃO-DESTRUTIVAS}

Para Ross et al. (1998), a avaliação não destrutiva é uma técnica de identificação das propriedades de um determinado material, realizada por meio de ensaios não destrutivos nos materiais, para verificar a existência ou não de descontinuidades ou defeitos, utilizando princípios físicos definidos, sem alterar suas características físicas, químicas, mecânicas ou dimensionais e sem interferir em seu uso posterior.

Todo método não destrutivo usa alguma forma de propagação de energia através ou em volta de um material para deduzir alguma característica importante do material examinado. Esta energia pode resultar de cargas estáticas ou dinâmicas ou ser gerada por ondas eletromagnéticas ou elásticas (SCHAD et al., 1996).

Jayne (1959) apresentou a hipótese que fundamenta a avaliação não destrutiva da madeira, propondo que a armazenagem de energia e as propriedades de dissipação da madeira, que podem ser medidas por meio não destrutivo, são controladas pelos mesmos mecanismos que determinam o comportamento deste material frente a solicitações estáticas. Dessa forma, em nível microscópico, as propriedades de armazenamento de energia são controladas pela orientação das células e pela composição estrutural, fatores que contribuem para a definição das características de elasticidade da madeira nas solicitações estáticas, sendo essas propriedades a frequência de oscilação na vibração ou transmissão da velocidade de propagação da onda. Assim, a dissipação da energia na madeira ocorre à medida que as vibrações livres são minimizadas por conta de defeitos, aumento de espaços vazios ocasionados por deterioração, rachaduras e por conta do intemperismo natural.

Em materiais homogêneos e isotrópicos como aço, plásticos e cerâmicas, a avaliação não destrutiva detecta falhas surgidas no processo de fabricação. Na madeira, essas 
irregularidades ocorrem naturalmente e a influência dessas sobre as propriedades mecânicas pode ser avaliada através de métodos não destrutivos (BUCUR, 1995). Porém, as irregularidades na madeira também implicam em erros de avaliação, uma vez que as equações que regem o comportamento de cada uma destas técnicas consideram o material como sendo homogêneo, isotrópico e contínuo (CARREIRA et al., 2006).

As vantagens que os métodos não destrutivos apresentam sobre os métodos tradicionais são: a possibilidade de utilização posterior da peça testada; a rapidez de aplicação do método; a confiabilidade dos valores apresentados, redução das perdas de material, classificação de peças em classes de qualidade e resistência, contribuindo todos esses fatores para uma economia financeira e de matéria-prima (PUEHRINGER, 2002). Outra vantagem é que as metodologias não-destrutivas podem ser aplicadas mesmo quando a peça está em utilização estrutural.

Segundo Erikson et al. (2000), a avaliação não destrutiva é uma importante ferramenta para a caracterização da madeira, podendo ser utilizada pelas indústrias para melhorar o controle de qualidade dos processos através de uma maior uniformidade na matéria prima e em seus derivados.

De acordo com Ross (1999), várias tecnologias não-destrutivas são usadas para avaliar a madeira, como raio-X, propriedades vibracionais e transmissão de ondas.

Estudos têm sido conduzidos no Brasil utilizando técnicas não destrutivas, tais como o ultrassom, ondas de tensão, espectroscopia no infravermelho próximo e médio, colorimetria, fluorescência molecular, os quais têm apresentado resultados satisfatórios, porém ainda requerem um maior nível de aprofundamento e conhecimento das técnicas (COSTA, 2009; RIBEIRO, 2009; SOUZA et al., 2010; STANGERLIN, 2012; TELES, 2014; OLIVEIRA et al.; 2015).

\subsection{COLORIMETRIA}

A cor é um aspecto físico da natureza. Cada pessoa a percebe de uma forma particular, através dos olhos, órgãos sensíveis à ação da região do visível, intervalo que se localiza entre 400 e 700 nanômetros no espectro eletromagnético (CAMARGOS, 1999).

Para Silva (2004), a questão do peculiar caráter abstrato da cor, permite a sua definição de várias formas. Ela é uma característica de objetos que emitem, refletem ou transmitem 
radiação na faixa visível. É, também, uma sensação criada pela radiação e interpretada ou lembrada pelo homem e alguns seres vivos.

A cor de um objeto é determinada quando a radiação eletromagnética incide sobre o mesmo e, uma parte da radiação é absorvida e outra é refletida, sendo que o comprimento de onda refletido caracterizará a cor do material (GONÇALEZ, 1993).

O espectro visível (Figura 4.5) apresenta sete cores, que refletem a luz em intervalos de comprimento de onda característicos, chamados de domínios da cor.

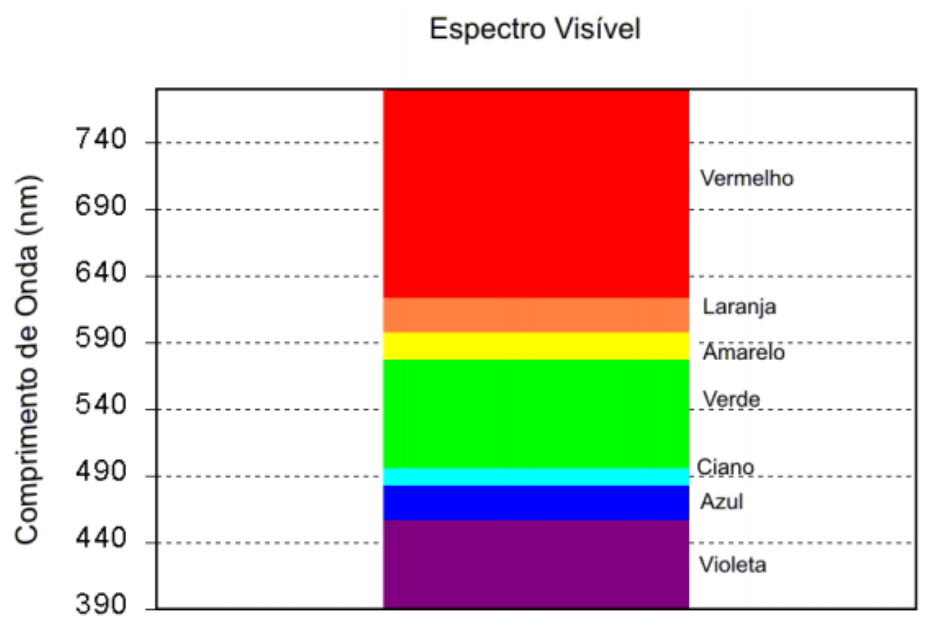

Figura 4.5 As cores e seus domínios. Fonte: Gouveia (2008).

Segundo Mori et al. (2005), a importância da determinação da cor de qualquer material se torna evidente, uma vez que ela é um dos primeiros contatos visuais, podendo indicar de forma imediata sua finalidade. Para o caso específico da madeira, a cor é uma das características mais importantes para a identificação e indicação de usos de diferentes espécies, principalmente quando associada aos aspectos de textura e desenho (CAMARGOS; GONÇALEZ, 2001).

Fundamentalmente, para que exista a cor, é necessária a presença de três variáveis importantes: da fonte luminosa, do objeto e do observador. Entretanto, a atribuição de uma determinada cor, exclusivamente, pela análise visual de um objeto é subjetiva, uma vez que podem haver diferenças de acordo com o observador e a fonte de luminosidade utilizada. Visando contornar o aspecto subjetivo no processo de determinação da cor, foram desenvolvidos métodos comparativos e quantitativos de medição de cores. (STANGERLIN, 2012). 
Existem dois métodos para a determinação da cor, o método comparativo e o quantitativo. O método comparativo ou sistema de ordenação de cores mais conhecido é o sistema Munsell, enquanto o método quantitativo mais utilizado é a colorimetria (GONÇALEZ et al., 2001).

A colorimetria emprega variáveis numéricas para as interações provocadas pela luz numa superfície e foi desenvolvido com a finalidade de evitar a confusão atribuída a diversidade de sensações psicofísicas ao se determinar as cores de objetos (GONÇALEZ, 1993). Este método descreve cada elemento da composição de uma cor numericamente por meio de um aparelho apropriado e é usada em diferentes sistemas de produção fabril, como por exemplo, indústrias têxteis, químicas e plásticas (MORI et al., 2005).

A colorimetria é considerada uma metodologia objetiva e eficaz para a medição da cor, classificação e caracterização da madeira, baseando-se no sistema CIELAB 1976 (Comission International de L'Eclairage ou Comissão Internacional de Iluminantes) (GONÇALEZ et al., 2001; MORI et al., 2004).

Os dois principais tipos de instrumentos utilizados para medição da cor são os espectrofotômetros e os colorímetros. Utilizando para as suas leituras a fonte de luz e iluminação padrão a fim de evitar as oscilações de iluminação do dia, e com a mesma sensibilidade correspondente à do olho humano, o colorímetro ou espectrofotômetro, percebe e registra as minuciosas diferenças de cores (MORI et al., 2005).

Basicamente, os dois instrumentos se diferenciam pelo fato de os colorímetros possuírem uma série de filtros e fotodetectores para quantificar a cor dos materiais expostos à luz, enquanto que os espectrofotômetros iluminam a superfície do objeto a ser medido e empregam um sistema de dispersão da radiação, normalmente baseado em grades de difração ou prismas, que permite medir a radiação refletida com uma exatidão e precisão de comprimento de onda muito maior do que em colorímetros (RAPPOLD; SMITH, 2004).

Com o avanço da ciência e tecnologia, os espectrofotômetros passaram a ser portáteis e tiveram seus custos reduzidos significativamente e, como consequência, os colorímetros perderam as suas vantagens competitivas.

O sistema CIE (Comission International de L'Eclairage ou Comissão Internacional de Iluminantes) é um método que define a sensação da cor baseado em três elementos: a 
luminosidade ou claridade, a tonalidade ou matiz e a saturação ou cromaticidade (CAMARGOS; GONÇALEZ, 2001).

O sistema CIELab (Figura 4.6) é resultado do contínuo desenvolvimento de espaços de cores e variações do espaço XYZ com o objetivo de fornecer uma melhor uniformidade perceptiva e correlação com a percepção humana das cores. Foi adotado pela CIE em 1976 e é baseado em seu antecessor (1942) sistema de Richard Hunter chamado L, a, b, o qual está baseado na teoria da oposição das cores correlacionada com a descoberta (1960) de que em algum lugar entre o nervo óptico e o cérebro os estímulos coloridos na retina são traduzidos em distinções entre claro e escuro, vermelho e verde, azul e amarelo (HOLDSHIP, 2008).

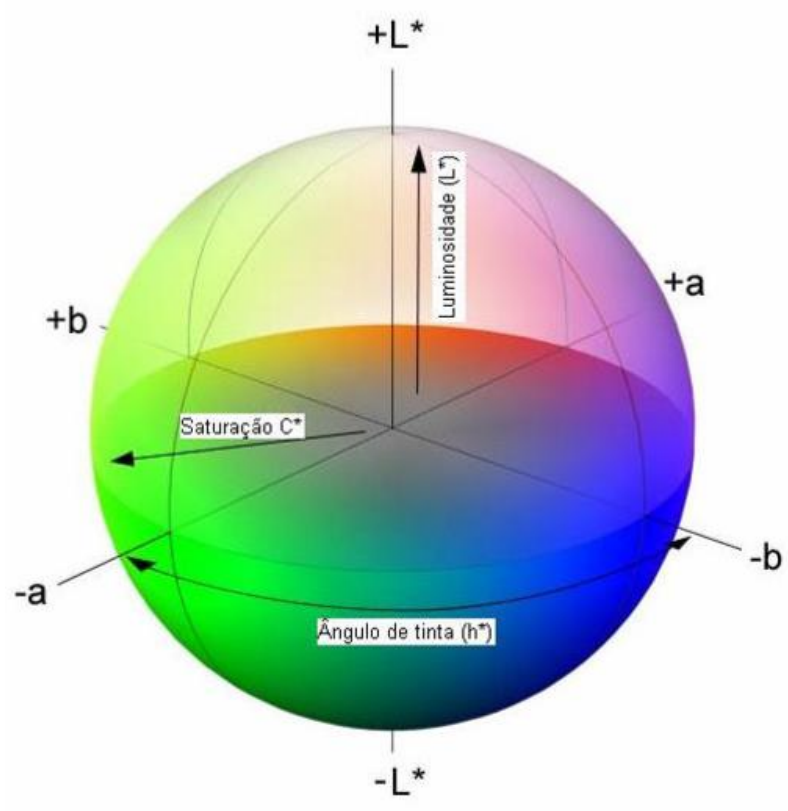

Figura 4.6 Representação das cores no sistema CIELab. Fonte: Color Models (2011), adaptado por Stangerlin (2012).

A claridade ou luminosidade define a escala cinza entre o branco e o preto. Pode ser representada, graficamente, por uma reta perpendicular a um círculo passando pelo seu centro. É expressa pela variável $L^{*}$ e assume o valor 0 para o preto absoluto e 100 para o branco total (CAMARGOS, 1999).

A tonalidade é expressa pelas cores primárias vermelho, verde, amarelo e azul. É representada em forma de um círculo cortado por duas retas perpendiculares (horizontal e vertical) passando pelo centro. A reta horizontal representa o vermelho e o verde, definidos por duas semi-retas, respectivamente, que vão do centro às extremidades do círculo. $\mathrm{O}$ 
vermelho vai do centro à periferia, formando um ângulo de $0^{\circ}$ e o verde vai do centro à extremidade oposta ao vermelho, formando um ângulo de $180^{\circ}$. Na reta vertical, estão o amarelo e o azul. A semi-reta do amarelo vai do centro à extremidade do círculo, formando um ângulo de $90^{\circ}$. O pigmento azul vai do centro à outra extremidade oposta ao amarelo, formando um ângulo de $270^{\circ}$. Os pigmentos vermelho, verde, amarelo e azul são definidos pelas variáveis $+a^{*} ;-a^{*},+b^{*} \mathrm{e}-b^{*}$, respectivamente. Cada variável assume valores entre 0 e 60. A tonalidade também pode ser obtida pelo ângulo de tinta, expresso pela variável h*, que é derivada dos valores de $a^{*}$ e b* e varia entre 0 e 60 (CAMARGOS, 1999).

A saturação ou cromaticidade, representada pela variável C, é o desvio a partir do ponto correspondente ao cinza no eixo L* (luminosidade). Quanto mais distante do eixo, mais saturada será a cor. A saturação, em termos mais detalhados, seria o raio do círculo de tonalidade, partindo do ponto cinza do eixo de luminosidade até a cor pura espectral localizada na extremidade do círculo. Esta variável também assume valores entre 0 e 60 (CAMARGOS, 1999).

A direção da diferença de cor, entre uma amostra e a referência, no espaço tridimensional é descrito pela magnitude e o sinal algébrico das coordenadas $L^{*}$, a* e b* (Equações 4.1 a 4.3) (CAMARGOS, 1999).

$$
\begin{aligned}
& \Delta \mathrm{L}^{*}=\Delta \mathrm{L}_{\mathrm{a}}^{*}-\Delta \mathrm{L}_{\mathrm{b}}^{*} \\
& \Delta \mathrm{a}^{*}=\Delta \mathrm{a}_{\mathrm{a}}^{*}-\Delta \mathrm{a}^{*} \\
& \Delta \mathrm{b}^{*}=\Delta \mathrm{b}_{\mathrm{a}}^{*}-\Delta \mathrm{b}^{*}
\end{aligned}
$$

Em que: $L_{a}^{*}, a_{a}{ }^{*}$ e $b_{a}{ }^{*}$ são referentes a amostra em ensaio, e $L_{b}{ }^{*}, a_{b} *$ e $b_{b}{ }^{*}$ são referentes $a$ amostra padrão (referência).

Portanto, valores de $\Delta \mathrm{L}^{*}, \Delta \mathrm{a}^{*} \mathrm{e} \Delta \mathrm{b}^{*}$ positivos indicam que a amostra analisada é mais clara, avermelhada e amarelada, respectivamente, do que a amostra padrão. Enquanto que os valores negativos dos mesmos parâmetros significam que a amostra é mais escura, esverdeada e azulada, respectivamente, do que o padrão.

Para Gonçalez et al. (2001), o sistema CIELab fornece um espaço mais uniforme da distribuição das cores, possibilitando uma melhor caracterização da cor do material. Assim, o uso de coordenadas cromáticas permite separar as madeiras em grupos de tonalidade, facilitando a aquisição e o uso específico (MORI et al., 2004). 
A cor de uma madeira não é estável, podendo alterar-se com o passar do tempo, com frequência escurecendo, em função da oxidação causada sobretudo pela luz, que reage com componentes químicos, principalmente extrativos e lignina (TSOUMIS, 1991).

Os extrativos, mesmo em pequenas quantidades, têm grande importância na determinação da cor da madeira e os principais responsáveis pela mudança de cor da madeira são quinonas, flavonóides, lignanas e taninos (TSOUMIS, 1991; RAPPOLD; SMITH, 2004).

Segundo Burger e Richter (1991), a cor e o desenho estão intrinsecamente relacionados com a anatomia da madeira. Fatores como espessura e orientação de fibras, quantidade de parênquima axial, largura de raio, diâmetro, distribuição e frequência de poros e outros, contribuem sobremaneira para a figura e a cor da madeira. Além desses fatores, destacam também o regime de crescimento da árvore e os tratos silviculturais que provocam o surgimento de nós, de canais traumáticos e de irregularidade nos anéis de crescimento.

Vários fatores podem influenciar na cor da madeira e alterá-la, tais como composição química, anatomia, método de derrubada da árvore, posição da amostra na árvore, meio ambiente, altura, diâmetro e idade da árvore, fatores genéticos inerentes a cada espécie, teor de umidade, temperatura, deteriorações provocadas pelo ataque de organismos xilófagos ou reações fotoquímicas (GONÇALEZ, 1993; CAMARGOS; GONÇALEZ, 2001).

As técnicas de secagem e tratamentos térmicos adotados pelas indústrias também podem alterar a cor da madeira. Segundo Stenudd (2004), algumas indústrias tentam minimizar os impactos de tais alterações colorimétricas, diminuindo a temperatura de secagem nas estufas, porém, isto aumenta em 30 a $40 \%$ o tempo de secagem e, consequentemente, os custos.

As características gerais (textura, grã e figura) e os planos de orientação da madeira (transversal, longitudinal tangencial e longitudinal radial) também estão relacionadas diretamente com a cor da madeira (CAMARGOS, 1999).

O padrão de coloração de uma madeira pode variar em tonalidades que vão desde o bege claro até o marrom escuro, quase preto. Dentro dessa variação, existem madeiras amarelas, avermelhadas, roxas e alaranjadas (MORI et al., 2004).

Nesse sentido, alguns aspectos acerca da importância da determinação da cor da madeira foram destacados por Janin (1986) e citados por Gonçalez (1993): 
1. Como ciência florestal, numa visão futura - um maior estudo sobre os fatores que influenciam a cor permite conhecer melhor as espécies e sua silvicultura, composição química, anatomia e morfologia.

2. Aspecto tecnológico - a cor permite uma classificação de madeira para serrar e laminar.

3. Aspecto econômico - o preço de um $\mathrm{m}^{2}$ de lâmina pode variar de 1 a 5 vezes ou mais, dependendo da espécie, do aspecto e da cor da madeira. Por exemplo, para a madeira de carvalho (Quercus sp.) usado em compensado, o alto valor depende da cor: quanto mais clara, mais é apreciado.

De acordo com Mori et al. (2005), a análise final da cor de qualquer produto lhe garante um padrão de qualidade de mercado, exigido mundialmente. Ela é um dos componentes da estética, que se associa à superfície e ao desenho de uma peça de madeira. Por esta razão, esta propriedade deve ser incorporada ao planejamento visando a caracterização tecnológica da madeira, para atender aos usos mais nobres desse material.

Esta técnica permite uma classificação cromática com maior homogeneidade dos lotes de madeiras, aumentando a qualidade dos materiais fornecidos, de acordo com o uso final e ao mercado consumidor (AUTRAN; GONÇALEZ, 2006).

Gonçalez et al. (2006) reforçam a ideia que o consumidor, ao comprar artefatos de madeira, além de privilegiar quesitos como preço, qualidade e durabilidade, observa também a aparência do objeto, seu design e seus componentes, indicando que a cor é um fator importante na escolha.

O uso da colorimetria quantitativa, que determina de maneira exata a cor da madeira e que leva em consideração seu aspecto superficial (desenho, textura, grã), representa uma das melhores metodologias para o estudo e a determinação da qualidade da madeira sob o ponto de vista colorimétrico (GONÇALEZ et al., 2001; CAMARGOS; GONÇALEZ 2001).

O emprego da colorimetria, por meio do sistema CIELab, tem apresentado viabilidade na classificação da qualidade da madeira, permitindo agrupá-las segundo as suas propriedades mecânicas (MOYA; MARÍN, 2011) e físicas (NISHINO et al., 2000) similares.

Camargos e Gonçalez (2001) mediram a cor de 350 espécies de madeiras brasileiras e as reuniram em 33 grupos de cores homogêneas, visando confeccionar uma tabela de cores e facilitar a comercialização. 
A colorimetria também se mostrou viável para avaliação de processos de intemperismo e envelhecimento artificial (SILVA et al., 2007; MARTINS, et al., 2011), tratamentos térmicos (GOUVEIA, 2008; GRIEBELER, 2013; ZANUNCIO et al., 2014) e análise de madeira com diferentes produtos de acabamento (SILVA; PASTORE, 2004; PACE et al., 2014).

Estudos acerca da biodeterioração de madeiras mostraram que a colorimetria é uma técnica eficaz para o monitoramento do ataque de fungos e para diferenciação dos ataques de diferentes espécies de fungos (MORAIS; COSTA, 2007; COSTA, 2009; SOUZA et al., 2010; STANGERLIN, 2012; ALMEIDA et al., 2012; CARNEIRO et al., 2013).

\subsection{ESPECTROSCOPIA DE INFRAVERMELHO}

A radiação eletromagnética é uma forma de energia que é transmitida através do espaço em alta velocidade. Pode ser descrita como uma onda, com propriedades como comprimento de onda, frequência, velocidade e amplitude. E também pode ser descrita como partícula ou pacotes discretos de energia, chamados fótons ou quanta. As duas formas de descrição da radiação eletromagnética são complementares (SKOOG et al., 2009).

Analisando as propriedades da radiação eletromagnética como onda, o comprimento de onda

( $\lambda$ ) é a distância linear entre dois máximos ou mínimos sucessivos de uma onda. A frequência

(f) corresponde ao número de oscilações que ocorrem por unidade de tempo. A amplitude fornece a medida da intensidade do campo elétrico ou magnético no ponto de máximo da onda (SKOOG et al., 2009).

Ainda de acordo com estes autores, a radiação eletromagnética, como partícula, transporta uma certa quantidade de energia, definida pela equação de Planck (Equação 4.4).

$$
E=h v=\frac{h c}{\lambda}=h c \bar{v}
$$

Em que: $E=$ energia da radiação $(\mathrm{J}) ; h=$ constante de Planck $\left(6,626 \times 10^{-34} \mathrm{~J} . \mathrm{s}.\right) ; v=$ frequência $(\mathrm{Hz}), c=$ velocidade da luz; $\lambda=$ comprimento de onda $(\mu \mathrm{m}) ; \bar{v}=$ número de onda $\left(\mathrm{cm}^{-1}\right)$.

A partir desta equação, pode-se inferir que o número de onda e a frequência são diretamente proporcionais à energia do fóton, enquanto que o comprimento de onda é inversamente proporcional. É importante destacar que o número de onda é outra forma de descrever a radiação eletromagnética e é igual a $1 / \lambda$. 
Dentro desse contexto, a espectroscopia estuda a interação da radiação eletromagnética com a matéria, sendo um dos seus principais objetivos determinar as posições relativas dos níveis energéticos de átomos ou moléculas a partir de transições (diferença de energia entre os níveis) observadas através de um espectro. Porém, a radiação infravermelha não é energética o suficiente para causar transições eletrônicas, estando restrita a espécies moleculares que têm diferenças de energia entre vários estados vibracionais e rotacionais (SKOOG et al., 2002; SALA, 2008).

A espectroscopia vibracional no infravermelho teve origem em 1800, quando a radiação infravermelha foi descoberta por Herschel. Entretanto, somente em 1900, a técnica foi desenvolvida por Coblentz após a obtenção de espectros de absorção no infravermelho de vários compostos orgânicos tanto no estado sólido, como no líquido e no gasoso (SALA, 2008).

No espectro eletromagnético (Figura 4.7), a região espectral do infravermelho corresponde à faixa de radiação com números de onda no intervalo de aproximadamente $12.800 \mathrm{~cm}^{-1} \mathrm{a}$ $10 \mathrm{~cm}^{-1}$ ou comprimentos de onda de $0,78 \mu \mathrm{m}$ a $1.000 \mu \mathrm{m}$. Ou seja, localiza-se entre a região do visível e das microondas. Do ponto de vista tanto da aplicação como da instrumentação, o espectro infravermelho é convenientemente dividido em radiação no infravermelho próximo (NIR, do inglês, Near Infrared Region), médio (MIR, do inglês, Medium Infrared Region) e distante (FIR, do inglês, Far Infrared Region) (Tabela 4.1) (SKOOG et al., 2002).

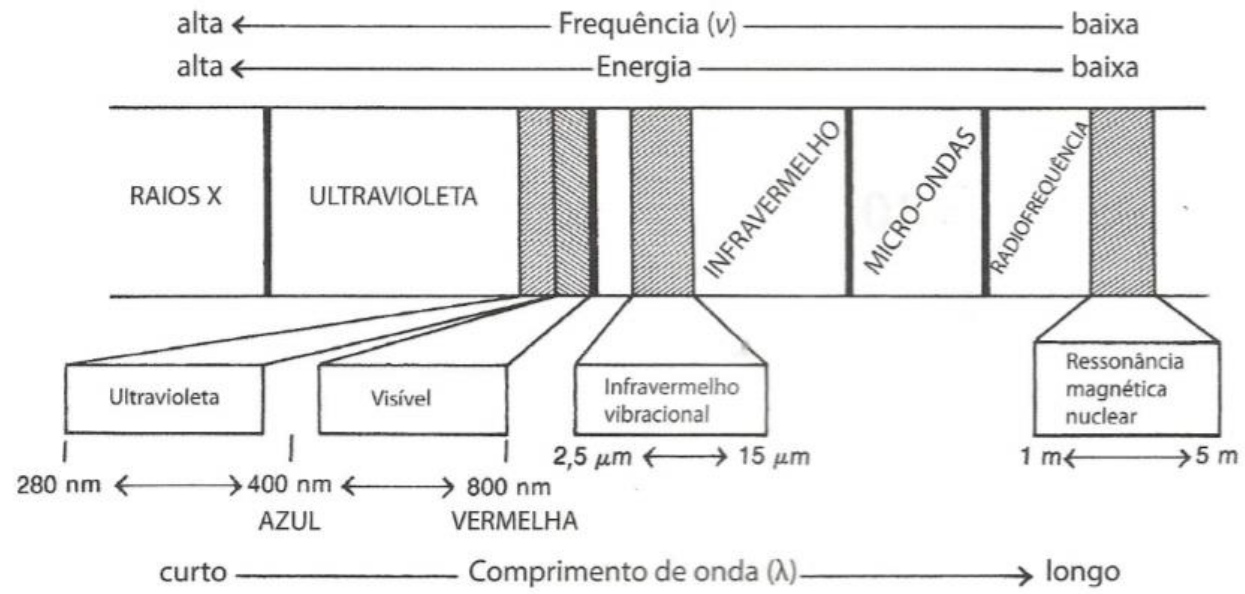

Figura 4.7 Região do infravermelho relacionada com as outras regiões do espectro eletromagnético. Fonte: Pavia et al. (2012). 
Tabela 4.1 Regiões do infravermelho. Fonte: Skoog et al. (2002).

\begin{tabular}{cccc}
\hline Região & $\begin{array}{c}\text { Intervalo de Comprimento } \\
\text { de Ondas }(\boldsymbol{\lambda}), \boldsymbol{\mu m}\end{array}$ & $\begin{array}{c}\text { Região de Número } \\
\text { de Onda }(\bar{v}), \mathbf{c m}^{-\mathbf{1}}\end{array}$ & $\begin{array}{c}\text { Região de } \\
\text { Frequência }(\boldsymbol{v}), \mathbf{H z}\end{array}$ \\
\hline Próximo & 0,78 a 2,5 & 12.800 a 4.000 & $3,8 \times 10^{14}$ a $1,2 \times 10^{14}$ \\
\hline Médio & 2,5 a 50 & 4.000 a 200 & $1,2 \times 10^{14}$ a $6,0 \times 10^{12}$ \\
\hline Distante & 50 a 1.000 & 200 a 10 & $6,0 \times 10^{12}$ a $3,0 \times 10^{11}$ \\
\hline
\end{tabular}

Para absorver radiação infravermelha, uma molécula precisa sofrer uma variação no momento dipolo como consequência do movimento vibracional ou rotacional. Quando uma molécula vibra, uma variação regular do momento dipolar ocorre e surge um campo que pode interagir com o campo elétrico associado à radiação. Se a frequência da radiação coincidir exatamente com a frequência vibracional natural da molécula, ocorre uma transferência de energia efetiva e resulta em uma variação da amplitude da vibração molecular; a absorção da radiação é a consequência. Do mesmo modo, a rotação de moléculas assimétricas em torno dos seus centros de massa resulta em uma variação periódica do dipolo que pode interagir com a radiação (SKOOG et al., 2002).

Entretanto, em moléculas homonucleares como $\mathrm{O}_{2}, \mathrm{~N}_{2}$ ou $\mathrm{Cl}_{2}$

, não ocorre variação efetiva no momento de dipolo durante a vibração ou rotação. Isto implica que essas substâncias não podem absorver no infravermelho. Com exceção deste tipo de molécula, todas as outras espécies moleculares absorvem radiação infravermelha (SKOOG et al., 2002).

As vibrações moleculares (Figura 4.8) podem ser classificadas nas categorias de estiramento e de deformações. Uma vibração de estiramento envolve uma variação contínua na distância interatômica ao longo do eixo da ligação entre dois átomos e são de dois tipos: simétricas e assimétricas. As vibrações de deformação são caracterizadas por uma variação no ângulo entre duas ligações e são de quatro tipos: deformação simétrica no plano (scissoring, em inglês), deformação assimétrica no plano (rocking, em inglês), deformação simétrica fora do plano (wagging, em inglês) e deformação assimétrica fora do plano (twisting, em inglês) (HOLLER et al., 2009). 


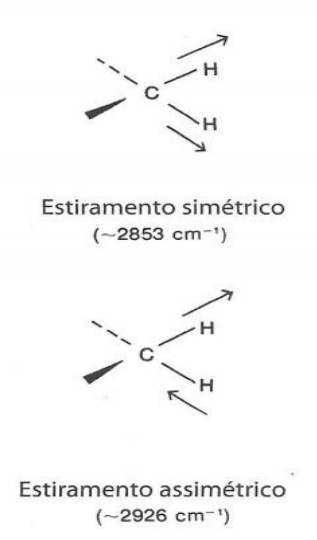

(a)
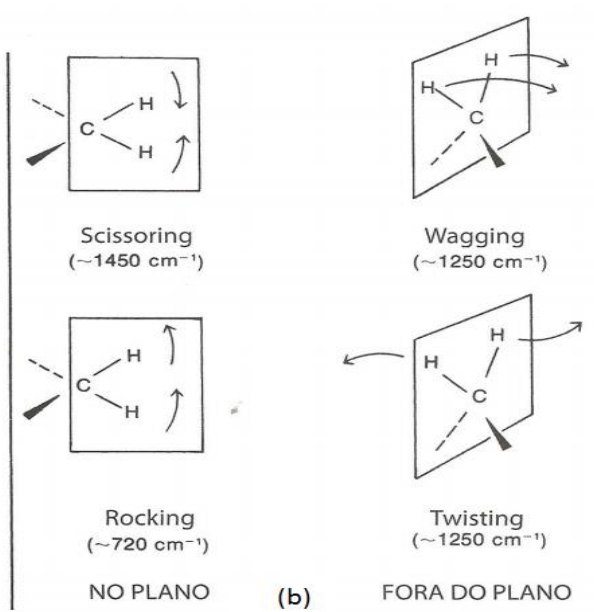

Figura 4.8 Tipos de vibrações moleculares. (a) Vibrações de estiramento e (b) Vibrações de deformação angular. Fonte: Holler et al. (2009).

Para uma molécula diatômica simples, a frequência de uma dada vibração de estiramento, baseada em um modelo mecânico de movimento harmônico simples, depende da massa dos átomos ligados e da constante de força da ligação entre eles. Porém, no caso de moléculas poliatômicas, a frequência também é ligeiramente afetada pelos outros átomos ligados (MENDHAM et al., 2002).

Nos espectros, as bandas de absorção geralmente são caracterizadas em unidades de números de ondas $(\bar{v})$, que são expressas em $\mathrm{cm}^{-1}$. Às vezes, comprimentos de onda $(\lambda)$, medidos em $\mu \mathrm{m}$, são utilizados. Por sua vez, as intensidades das bandas podem ser expressas como transmitância ou absorbância. A transmitância é a razão entre a energia radiante transmitida por uma amostra e a energia radiante que nela incide. A absorbância é o logaritmo decimal do inverso da transmitância, isto é, $A=\log _{10}(1 / T)$ (MENDHAM et al., 2002; SILVERSTEIN et al. 2012).

Para Silverstein et al. (2012), embora o espectro de infravermelho seja característico da molécula como um todo, certos grupos de átomos dão origem a bandas que ocorrem mais ou menos na mesma frequência, independente da estrutura da molécula. E é justamente a presença dessas bandas características de grupos que permite a obtenção de informações úteis para a identificação de estruturas desconhecidas. Pavia et al. (2012) ressaltam que o espectro infravermelho pode servir para moléculas da mesma forma que impressões digitais servem para os seres humanos.

As bandas de absorção úteis para a identificação de grupos funcionais estão localizadas na região do infravermelho de comprimentos de onda mais curtos (de cerca de 2,5 $\mu \mathrm{m}$ a 8,5 
$\mu \mathrm{m})$. Portanto, a investigação dessa região do espectro fornece informações consideráveis sobre a estrutura geral da molécula analisada (SKOOG et al., 2009). Entretanto, pequenas diferenças na estrutura e na constituição de uma molécula resultam em alterações significativas na distribuição dos máximos de absorção do espectro que se estende de aproximadamente $8 \mu \mathrm{m}$ a $14 \mu \mathrm{m}$, denominada região de impressão digital. Deste modo, é uma região bastante apropriada para identificar compostos com base em comparações espectrais (HOLLER et al., 2009).

Para obtenção de espectros de infravermelho são utilizados basicamente três tipos de instrumentos: espectrômetros dispersivos, espectrômetros com transformada de Fourier e fotômetros de filtro.

O espectrômetro de infravermelho dispersivo é empregado para obter espectros para identificação qualitativa. São geralmente de feixe duplo, instrumentos com registrador, que empregam redes de difração para dispersar a radiação (PAVIA et al., 2012). Apesar da vantagem de apresentar baixo custo em relação ao espectrômetro com transformada de Fourier, caracteriza-se pela lenta digitalização do espectro, já que somente uma pequena fração de frequência é detectada por unidade de tempo. Outro fator negativo é que com o uso contínuo do aparelho, a precisão é reduzida, causando fadiga mecânica (PASQUINI, 2003).

Os instrumentos com transformada de Fourier não contêm nenhum elemento de dispersão e todos os comprimentos de onda são detectados e medidos simultaneamente empregando-se um interferômetro de Michelson. Na Figura 4.9 pode-se observar o esquema de funcionamento do instrumento em que, inicialmente, a radiação infravermelha proveniente da fonte atravessa um divisor de feixes. Um feixe é desviado por $90^{\circ}$ para um espelho fixo e é refletido de volta para o divisor de feixes. O outro feixe que não sofreu desvio é direcionado para um espelho móvel e também é refletido para o divisor de feixes. Quando os dois feixes se reencontram no divisor de feixes, eles se recombinam, mas as diferenças de caminhos (diferentes extensões da onda) dos dois feixes causam interferências construtivas e destrutivas. O feixe combinado dá origem ao interferograma, que essencialmente é um gráfico de intensidade versus tempo (domínio temporal). Então, este é decodificado ou convertido pela transformada de Fourier para o domínio de frequências. O feixe combinado também passa pela amostra, e esta absorve de forma simultânea todos os comprimentos de onda normalmente encontrados em seu espectro infravermelho. O sinal do interferograma 
modificado chega ao computador, é comparado com o interferograma de referência e convertido pela transformada de Fourier, extraindo-se as frequências que foram absorvidas e reconstruindo o gráfico de um típico espectro de infravermelho (SKOOG et al., 2009; PAVIA et al., 2012).

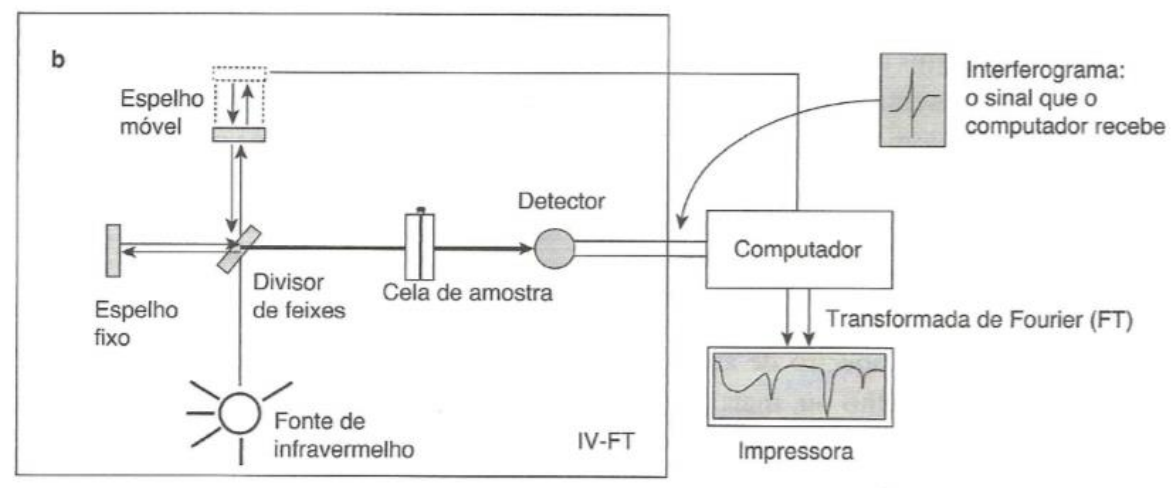

Figura 4.9 Diagrama esquemático de espectrômetros com transformada de Fourier. Fonte: Pavia et al. (2012).

Os espectrômetros com transformada de Fourier apresentam algumas vantagens em relação ao demais instrumentos. Como possuem poucos instrumentos ópticos e não possuem fendas que atenuem a radiação, a potência radiante que atinge o detector é muito maior do que nos instrumentos dispersivos e razões sinal/ruído muito maiores são observadas. Apresentam também alta resolução e determinações de frequência altamente exatas e reprodutíveis. Além disso, todos os elementos da fonte atingem o detector simultaneamente, possibilitando a obtenção de dados de todo o espectro em 1 segundo ou menos (SKOOG et al., 2002; HOLLER et al., 2009).

Os fotômetros de filtro foram desenvolvidos para análise quantitativa no infravermelho. Este tipo de instrumento é sensível a décimos de parte por milhão na detecção de substâncias. São menos complexos e mais baratos que os instrumentos descritos anteriormente (SKOOG et al., 2002; HOLLER et al., 2009).

Para fins analíticos, a região mais interessante e amplamente utilizada, tanto para análise qualitativa como quantitativa, é a do infravermelho médio. Skoog et al. (2002) ressaltam que as espectrometrias de absorção e reflexão no infravermelho médio são ferramentas fundamentais para a determinação de espécies orgânicas e bioquímicas, uma vez que a região de impressão digital ocorre dentro do intervalo que caracteriza o infravermelho médio. 
Segundo Pastore (2004), o uso da interferometria acoplada ao desenvolvimento de microprocessadores dedicados, que transformam (via transformada de Fourier) o interferograma (intensidade no domínio do tempo) no espectro (intensidade no domínio da frequência), levou a um aumento significativo na sensibilidade da espectroscopia de absorção no infravermelho (IR), provocando o ressurgimento das técnicas de reflexão, principalmente, as de refletância total atenuada (ATR - Attenuated Total Reflectance) e refletância difusa (DRIFT - Diffuse Reflectance Infrared Fourier Transform) que são mais apropriadas para o estudo de superfícies.

A maioria dos fabricantes de instrumentos oferece adaptadores para os instrumentos de absorção no infravermelho, que tornam possível a obtenção imediata de espectros de reflexão (SKOOG et al., 2002).

Dentre as técnicas de reflexão, a utilizada com maior frequência para análise de madeiras é a DRIFT, uma vez que, ao ser comparada a ATR, não necessita do estabelecimento de um eficiente contato óptico entre a superfície do cristal e a amostra em estudo (MOORE; OWEN, 2001; PASTORE, 2004). Segundo Pastore (2004), a espectroscopia DRIFT também apresenta anomalia e distorções quando os espectros são obtidos diretamente da superfície de um bloco de madeira em função dos desvios ópticos, porém, isto não inviabiliza a utilização da técnica em estudos onde não se deseja uma interferência na superfície da amostra, como no caso de amostras deterioradas por fungos (COSTA, 2009; STANGERLIN, 2012) ou termicamente tratadas (GOUVEIA, 2008), por exemplo.

Nesse sentido, têm sido realizados estudos utilizando a técnica de espectroscopia no infravermelho e demonstrada a sua viabilidade em análises acerca das modificações ocorridas na estrutura da madeira após deterioração causada por fungos (FERRAZ et al., 2000; PANDEY; PITMAN, 2003; COSTA, 2009; STANGERLIN, 2012); predição de propriedades tecnológicas (VIANA, 2008; RIBEIRO, 2009); discriminação entre madeiras semelhantes (PASTORE et al., 2011), folhosas e coníferas (BARKER; OWEN, 1999), madeiras intemperizadas (PASTORE, 2004) e termicamente tratadas (GOUVEIA, 2008).

\subsection{FLUORESCÊNCIA MOLECULAR}

A luminescência molecular consiste na emissão de radiação eletromagnética proveniente de moléculas que foram excitadas. Quando a excitação da molécula é feita pela absorção de fótons, fazendo com que a molécula passe de um estado de energia fundamental para um estado de energia excitado, denomina-se de fotoluminescência. Assim, a fotoluminescência 
é dividida em fluorescência e fosforescência, dependendo da natureza do estado excitado envolvido no processo (VALEUR, 2001; HOLLER et al., 2009).

Um dos aspectos mais relevantes dos métodos de luminescência é a sua sensibilidade intrínseca, com limites de detecção frequentemente de uma a três ordens de grandeza melhores que os encontrados em espectroscopia de absorção óptica. Este aumento de sensibilidade é devido principalmente à seletividade da técnica, já que, na fluorescência, a luz de excitação que incide na amostra seleciona a espécie que será excitada de acordo com os níveis de energia disponíveis no material. Outra vantagem dos métodos fotoluminescentes é a sua extensa faixa de concentração linear, que também é significativamente maior que as encontradas em métodos de absorção óptica. Devido à sua alta sensibilidade, os métodos luminescentes quantitativos estão sujeitos a efeitos de interferência das matrizes da amostra. Por este fato, muitas vezes as medidas de luminescência são combinadas com técnicas de separação, como a cromatografia e eletroforese (HOLLER et al., 2009). Contudo, os métodos de fluorescência são muito menos aplicados que os métodos de absorção em razão do número limitado de sistemas químicos que fluorescem com intensidade apreciável (SKOOG et al., 2009).

Atualmente, se tem o conhecimento de que a fluorescência, é uma etapa do processo de desativação, ou seja, processo pelo qual uma molécula excitada volta ao seu estado fundamental, havendo emissão de um fóton de radiação. A trajetória favorecida para o estado fundamental é aquela que minimiza o tempo de vida do estado excitado (SKOOG et al., 2002).

A fluorescência é intrinsecamente o fenômeno luminescente mais comum que a fosforescência, competindo eficientemente com processos de desativação não radiativos do estado excitado. Por este fato, é possível observar facilmente a fluorescência na temperatura ambiente e diretamente em solução (VALEUR, 2001; HOLLER et al., 2009). A fluorescência é muito mais empregada em análise química que a fosforescência (SKOOG et al., 2009).

Todas as moléculas absorventes apresentam potencial para fluorescerem, contudo, muitos compostos não o fazem porque suas estruturas provêem caminhos para a relaxação nãoradioativa mais rápida que a emissão fluorescente (SKOOG et al., 2009).

Muitos processos que causam a perda do excesso de energia da molécula podem ocorrer, sendo que a relaxação vibracional e a conversão interna são os dois métodos de relaxação 
não-radioativa que competem com a fluorescência, apresentados na Figura 4.10. Mais especificamente, a relaxação vibracional ocorre durante as colisões entre as moléculas excitadas e as moléculas do solvente, ou seja, envolve a transferência do excesso de energia de uma espécie excitada vibracionalmente para as moléculas do solvente. Esse processo ocorre na escala de tempo entre $10^{-11}$ e $10^{-10} \mathrm{~s}$ e deixa as moléculas no estado vibracional mais baixo de um estado eletrônico excitado. A conversão interna também ocorre muito rápido $\left(10^{-12} \mathrm{~s}\right)$ e é um processo que envolve a transferência do excesso de energia das espécies presentes no estado vibracional de mais baixa energia para as moléculas do solvente e a conversão as espécies excitadas para um estado eletrônico mais baixo (SKOOG et al., 2009).

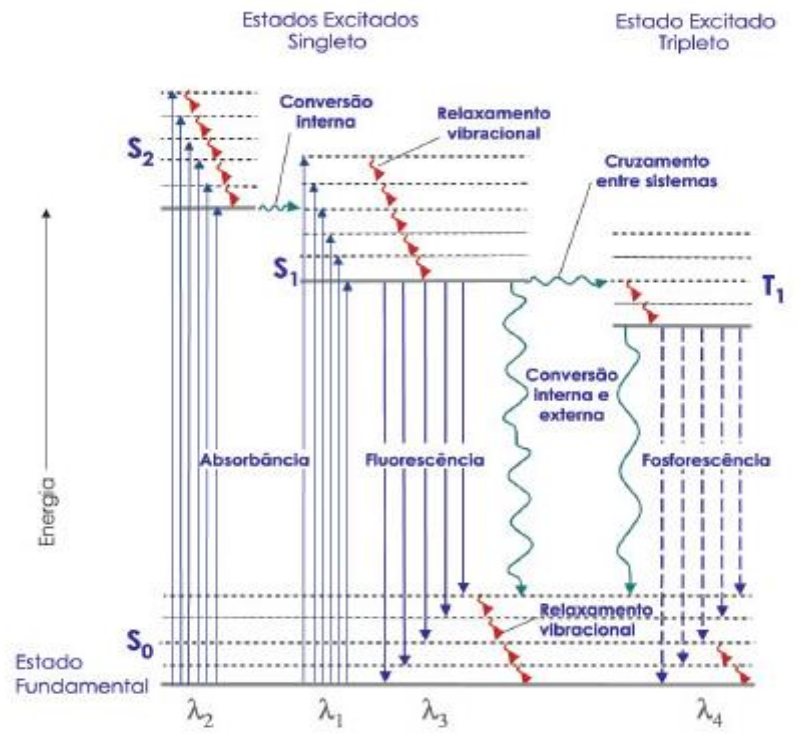

Figura 4.10 Diagrama de Jablonski. Fonte: Skoog et al. (2002).

Quase sempre, a fluorescência é observada a partir do estado excitado eletrônico mais baixo $\mathrm{E}_{1}$ para o estado fundamental $\mathrm{E}_{0}$. Também, geralmente, a fluorescência ocorre somente do nível vibracional mais baixo de $\mathrm{E}_{1}$ para vários níveis vibracionais de $\mathrm{E}_{0}$. Isto porque os processos de conversão interna e a relaxação vibracional são muito rápidos quando comparados com a fluorescência (SKOOG et al., 2009).

A fluorescência ocorre em sistemas químicos gasosos, líquidos e sólidos que podem ser simples ou complexos. (HOLLER et al., 2009).

Quando uma substância é fluorescente, a detecção fluorimétrica direta é possível por meio de um espectrofluorímetro operando a uma excitação apropriada e comprimentos de onda de emissão (VALEUR, 2001). 
Basicamente, a fluorescência molecular é medida excitando-se a amostra no comprimento de onda de absorção, também conhecido como comprimento de onda de excitação, e medindo-se a emissão a um comprimento de onda mais alto denominado comprimento de onda de fluorescência. Geralmente, a emissão fluorescente é medida em ângulo reto em relação ao feixe incidente para evitar a interferência desse feixe. A emissão de curta duração $\left(10^{-5} \mathrm{~s}\right.$ ou menos) que ocorre é chamada fluorescência, enquanto a luminescência de maior duração (pode durar muitos minutos ou mesmo horas) é denominada fosforescência (SKOOG et al., 2009).

A espécie mais simples de fluorescência é aquela apresentada por vapores atômicos diluídos, conhecida como radiação de ressonância ou fluorescência de ressonância. Por exemplo, os elétrons $3 \mathrm{~s}$ de átomos de vapor de sódio podem ser excitados ao estado $3 \mathrm{p}$ por absorção de radiação de comprimento de onda de 5.896 e $5.890 \AA$ A. Após $10^{-5}$ a $10^{-8} \mathrm{~s}$, os elétrons voltam ao estado fundamental e, ao fazer isso, emitem radiação dos mesmos dois comprimentos de onda em todas as direções. Esse tipo de fluorescência, em que a radiação absorvida é reemitida sem mudança de frequência é exibida por muitas espécies moleculares, porém, ainda em menor número se comparada à fluorescência que ocorre com deslocamento de comprimentos de onda (SKOOG et al., 2002).

As bandas de fluorescência molecular são constituídas por linhas que apresentam comprimento de onda maior, menor frequência, e assim de menor energia, que a banda de radiação absorvida para sua excitação. Esse deslocamento para os comprimentos de onda mais longos é denominado deslocamento Stokes (SKOOG et al., 2009).

A fluorescência convencional envolve a obtenção de um espectro de emissão pela varredura em uma determinada faixa de comprimentos de onda $\left(\lambda_{\text {em }}\right)$ quando uma amostra é irradiada com um comprimento de onda de excitação $\left(\lambda_{\text {exc }}\right)$ fixo. De maneira similar, um espectro de excitação é obtido pela varredura nos diferentes comprimentos de onda de excitação enquanto se registra o sinal de emissão em um único comprimento de onda. Contudo, existe a possibilidade de variar simultaneamente $\lambda_{\text {exc }}$ e $\lambda_{\text {em }}$, e dependendo da velocidade de varredura dos dois monocromadores é possível obter os diferentes formatos da técnica fluorimétrica conhecida como espectroscopia de fluorescência sincronizada (SOTOMAYOR et al., 2008).

O rendimento quântico de fluorescência molecular é dado pela razão entre o número de moléculas que fluorescem e o número total de moléculas excitadas, ou a razão entre os fótons 
emitidos e os fótons absorvidos. Sendo assim, moléculas que fluorescem intensamente apresentam eficiências quânticas que se aproximam da unidade sob certas condições, enquanto que espécies não fluorescentes apresentam eficiências essencialmente iguais a zero (SKOOG et al., 2009).

Esta técnica tem sido utilizada para analisar compostos de interesse farmacêutico, biológico, ambiental, industrial, dentre outros, viabilizando medidas da intensidade de emissão e/ou excitação livre de observações subjetivas, de maneira rápida e confiável (ZÚÑIGA, 2006; SOTOMAYOR et al., 2008; SCHERER, 2011; SILVA, 2012; MOURA, 2013; OLIVEIRA et al., 2015).

\subsubsection{Fatores que influenciam na fluorescência}

A fluorescência é uma técnica muito sensível e eficaz para analisar os mais variados tipos de amostras, sendo elas sólidas, em gás ou em solução (MOURA, 2013). Entretanto, alguns fatores influenciam a análise de fluorescência e, portanto, devem ser considerados no estudo, como o tipo de transição eletrônica, a estrutura molecular, a rigidez estrutural, o solvente, a temperatura, o pH, a concentração da espécie emissora, dentre outros.

Para Skoog et al. (2002), esses fatores influenciam a ocorrência ou não da luminescência de uma molécula e também determinam a intensidade da emissão.

A fluorescência dificilmente resulta da absorção de radiação ultravioleta de comprimentos de onda menores que $250 \mathrm{~nm}$, porque tal radiação é suficientemente energética para causar desativação dos estados excitados por pré-dissociação ou dissociação. Portanto, a fluorescência devido a transições $\sigma^{*} \rightarrow \sigma$ dificilmente é observada. Observa-se empiricamente que a fluorescência é mais comumente encontrada em compostos nos quais as transições de menor energia são do tipo $\pi \rightarrow \pi^{*}$ que em compostos nos quais a transição de menor energia é do tipo $n \rightarrow \pi^{*}$, ou seja, a eficiência quântica é maior para transições $\pi \rightarrow \pi^{*}$ (SKOOG et al., 2002).

Por ser uma técnica bastante seletiva, a intensidade de fluorescência tem sido relacionada à estrutura, tamanho e grau de policondensação dos compostos moleculares (CHEN, 2003). Compostos que contêm grupos funcionais aromáticos com transições de baixa energia apresentam emissão fluorescente mais intensa e mais útil. Compostos que contêm estruturas alifáticas e carbonilas alicíclicas ou estrutura com ligações duplas altamente conjugadas 
também fluorescem, apesar de existirem poucos desses compostos se comparado aos compostos aromáticos (SKOOG et al., 2002; HOOLER et al., 2009; SKOOG et al., 2009).

A maioria dos hidrocarbonetos aromáticos não-substituídos fluoresce em solução e a eficiência quântica aumenta com o número de anéis e seu grau de condensação. A substituição no anel benzênico causa deslocamentos nos comprimentos de onda dos máximos de absorção e mudanças correspondentes nos picos de fluorescência, afetando também a eficiência de fluorescência (SKOOG et al., 2002; SKOOG et al., 2009). De acordo com Senesi (1990), os substituintes receptores dos elétrons, tais como hidroxilas e aminas, reduzem a intensidade de fluorescência, enquanto que os substituintes doadores de elétrons, tais como os grupos carboxílicos, aumentam a intensidade de fluorescência medida.

A fluorescência é favorecida em moléculas que possuem estruturas rígidas, pois a rigidez diminui a velocidade da relaxação não-radioativa ao ponto em que a relaxação por fluorescência tenha tempo de ocorrer (SKOOG et al., 2009).

A temperatura influencia diretamente na eficiência quântica da fluorescência, uma vez que com o aumento da temperatura, há também o aumento da frequência de colisões e maior probabilidade de ocorrer a desativação por conversão externa (SKOOG et al., 2002; HOOLER et al., 2009; SKOOG et al., 2009).

A diminuição da viscosidade aumenta a facilidade da conversão externa, causando um decréscimo da fluorescência (HOOLER et al., 2009; SKOOG et al., 2009). Mais especificamente, a fluorescência de uma molécula é diminuída por solventes contendo átomos pesados ou outros solutos com tais átomos em suas estruturas (interações spin-órbita causam um aumento na velocidade da formação de triplete e um correspondente decréscimo na fluorescência). Compostos contendo átomos pesados são frequentemente incorporados em solventes quando deseja-se uma maior fosforescência (SKOOG et al., 2002).

O pH é um fator importante a ser considerado, pois o comprimento de onda e a intensidade de emissão são diferentes para formas protonadas, desprotonadas e neutras. Como resultado das diferenças de energia no estado fundamental e estados excitados, os espectros de fluorescência são pH-dependentes (MOURA, 2013).

\subsubsection{Instrumentos para medição de fluorescência}

Três instrumentos típicos para medidas de fluorescência são a câmara escura com lâmpada UV, o fluorímetro e o espectrofluorímetro. 
A maioria dos estudos acerca de fluorescência de madeira está relacionado à utilização de lâmpadas de UV em câmaras escuras (Figura 4.11). Primeiramente, as amostras são lixadas para retirada de camada oxidada e em seguida são colocadas a uma distância específica da lâmpada UV e a fluorescência visual é obtida. Esta medida é considerada subjetiva, uma vez que depende da capacidade visual do observador. É recomendada a visualização das amostras por mais de um observador, visando diminuir a subjetividade do método (WHEELER et al., 1989; MOURA, 2013;).

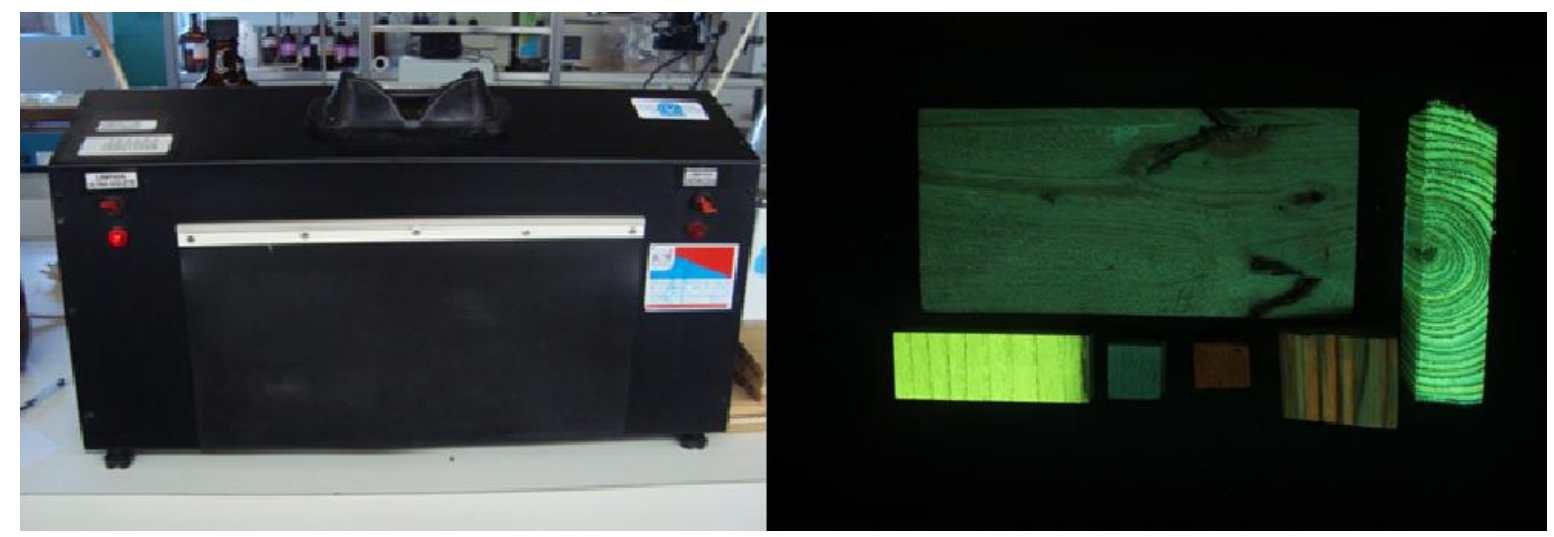

Figura 4.11 Câmara escura para visualização de fluorescência e amostras fluorescentes.

Os fluorímetros de filtro fornecem uma maneira simples de baixo custo para se realizar análises quantitativas por fluorescência. Tanto os filtros de interferência como os de absorção são usados para limitar os comprimentos de onda das radiações de excitação e de emissão. A fonte mais comum de fluorímetros de filtro é uma lâmpada de vapor de mercúrio de baixa pressão equipada com janela de sílica fundida. Essa fonte fornece linhas úteis para excitar fluorescência em 254, 302, 313, 546, 578, 691 e 773 nm. As linhas individuais podem ser isoladas com filtros de absorção ou interferência apropriados. Uma vez que a fluorescência pode ser induzida na maioria dos compostos fluorescentes por uma variedade de comprimentos de onda, pelo menos uma das linhas do mercúrio é frequentemente apropriada (SKOOG et al., 2002).

O funcionamento de um fluorímetro de filtro típico que utiliza uma fonte de mercúrio e um par de fotomultiplicadoras como transdutores está esquematizado na Figura 4.13. Primeiramente, o feixe da fonte é dividido próximo da mesma em um feixe de referência e um de amostra. $\mathrm{O}$ feixe de referência é atenuado por um disco perfurado de modo que a sua intensidade é aproximadamente a mesma da fluorescência. Ambos os feixes passam pelo filtro primário, com o feixe de referência sendo refletido para a fotomultiplicadora de referência. O feixe da amostra é focalizado na mesma por um par de lentes e causa a emissão 
de fluorescência. A radiação emitida passa por um segundo filtro e é focalizada na segunda fotomultiplicadora. As saídas elétricas dos dois transdutores seguem para um divisor analógico para calcular a razão das intensidades da amostra e da referência, que serve como variável analítica (SKOOG et al., 2002).

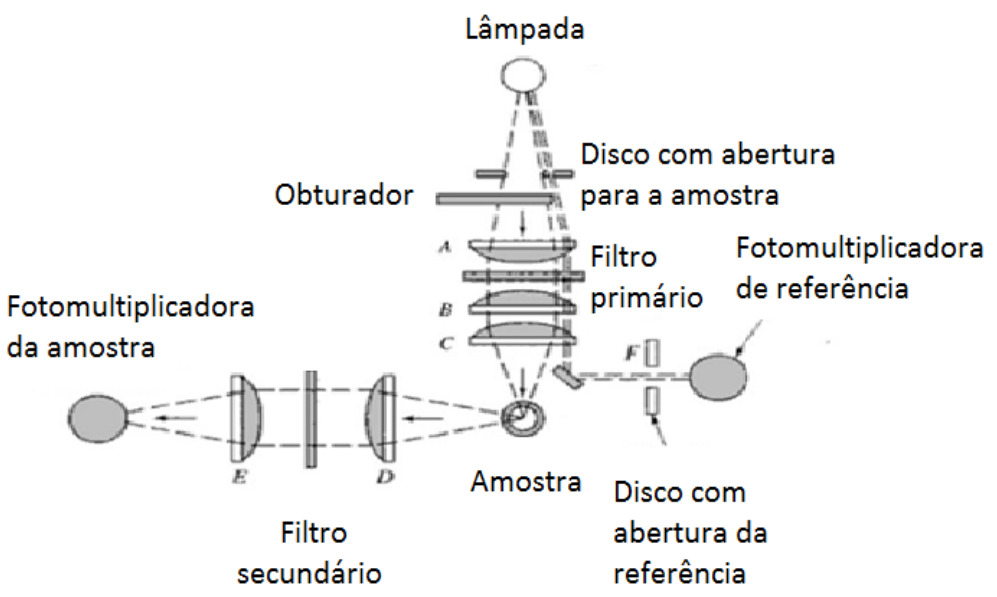

Figura 4.12 Esquema de funcionamento de um fluorímetro típico. Fonte: Holler et al. (2009).

O espectrofluorímetro caracteriza-se por possuir dois monocromadores como seletores de comprimento de onda. Estes dois monocromadores permitem a varredura do espectro de excitação, onde o comprimento de onda de excitação é varrido a um comprimento de onda de emissão fixo; do espectro de emissão, onde o comprimento de onda de emissão é varrido a um comprimento de onda de excitação fixo; ou de um espectro síncrono, onde é realizada uma varredura de ambos os comprimentos de onda com uma diferença fixa entre os dois monocromadores (SKOOG et al., 2009).

A Figura 4.13 ilustra o princípio básico de funcionamento de um espectrofluorímetro, onde uma fonte emite radiação em direção ao monocromador de excitação, um comprimento de onda de excitação é selecionado e a luminescência produzida pela amostra é direcionada para um segundo monocromador, normalmente posicionado a $90^{\circ}$ em relação a radiação incidente. A radiação emitida pelo monocromador de emissão segue para um transdutor e após, para o dispositivo de leitura. (HARRIS, 2005; SKOOG et al., 2009). Podem ser obtidos espectros de emissão, de excitação ou um espectro síncrono, conforme descrito anteriormente.

A seletividade oferecida pelos espectrofluorímetros é de importância primordial em investigações de características eletrônicas e estruturais de moléculas e é valiosa para trabalhos analíticos qualitativos e quantitativos (SKOOG et al., 2002). 


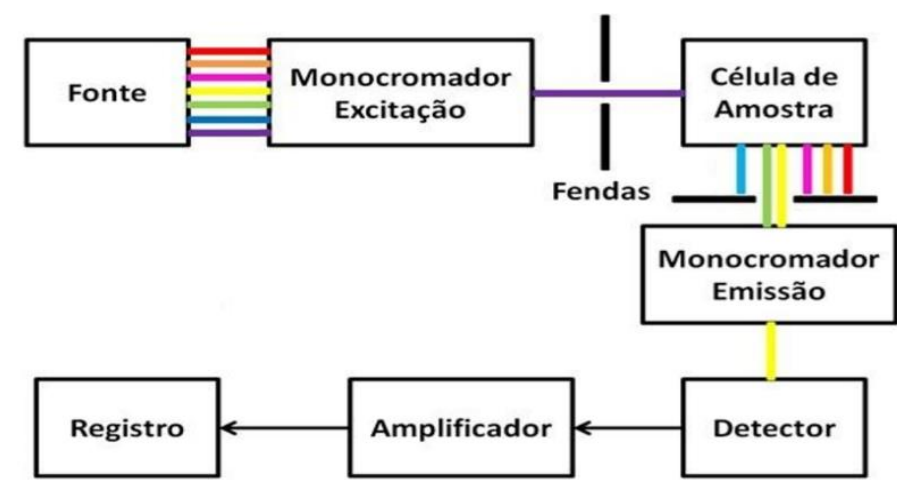

Figura 4.13 Esquema de funcionamento de um espectrofluorímetro. Fonte: Moura (2013).

\subsubsection{Fluorescência de madeiras}

O primeiro registro de observação do fenômeno fluorescência em madeiras se deu há mais de 400 anos atrás, com a madeira de Lignum nephriticum, a qual era bastante conhecida na Europa, nos séculos XVI e XVII, devido aos copos ou taças que eram confeccionados a partir desta madeira exótica, que exibia uma curiosa cor azul na superfície da água colocada no copo (MUYSKENS, 2006). Outros registros foram feitos em 1921, acerca da fluorescência de extratos aquosos de Aesculus hippocastanun e Fraxinus excelsior (STONE, 1921 apud AVELLA et al., 1988).

Dalton (1934) definiu o fenômeno de fluorescência como uma propriedade exibida por alguns materiais que, quando são excitados por raios ultravioleta ou raios $\mathrm{X}$, emitem radiação em outros comprimentos de onda, diferentes daqueles com os quais as substâncias estão sendo excitadas.

Para Muyskens (2006), a fluorescência ocorre quando uma substância absorve a luz numa região de comprimento de onda, e ao mesmo tempo emite luz numa região diferente do espectro, normalmente de maior comprimento de onda.

Devido ao maior interesse de pesquisadores em conhecer sobre este fenômeno peculiar, a IAWA definiu padrões para o procedimento de verificação de fluorescência de madeira, visando a comparação de resultados obtidos em locais diferentes. Assim, a IAWA sugere que, para a avaliação da fluorescência em uma amostra de madeira, esta deve ter uma superfície recém-raspada e a observação deve ser feita em uma sala ou câmara escura sob fonte de luz UV de alta intensidade e de comprimento de onda longo (365 nm) (WHEELER et al., 1989). 
Diferentes madeiras apresentam fluorescências distintas, com a cor variando entre o marrom e o violeta, com praticamente todos os tons de laranja, amarelo, verde, azul e anil entre esses extremos. A intensidade da fluorescência não está limitada a uma área particular da madeira. Em alguns casos, o cerne fluoresce mais do que o alburno e, em outros casos ocorre o inverso (KRISHNA; CHOWDHURY, 1935).

Krishna e Chowdhury (1935) e Dyer (1988) apud Pandey et al. (1998), após testes expondo amostras de espécies de madeiras indianas e sul-africanas à luz UV, verificaram que a fluorescência poderia ser uma das importantes características na identificação de madeiras e distinção de cerne e alburno em várias espécies de madeira.

Miller (2007) observou 50.000 espécimes da Coleção de Madeiras do Laboratório de Produtos Florestais de Wisconsin, sob luz UV em uma câmara escura. A fluorescência foi classificada em muito forte ou muito brilhante, forte ou positiva e fraca. Em seus resultados, ele concluiu que a cor mais frequente da fluorescência é o amarelo com uma mistura de tons de verde. Foi reforçada a ideia de que a fluorescência de madeiras mediante exposição à luz UV é uma importante característica de diagnóstico na identificação de madeira e pode ser importante na indicação de afinidades taxonômicas.

Teixeira et al. (2012) estudaram a emissão de fluorescência do cerne de espécies tropicais, e forneceram dados sobre a cor e a intensidade da fluorescência, destacando que o teste de fluorescência mostrou ser um método eficiente para auxiliar na diferenciação entre espécies que apresentam ou não fluorescência.

Duarte et al. (2014) estudaram o cerne de amostras de 12 espécies, visualmente similares ao mogno, utilizando gabinete (Prodicil, Brasil) com lâmpada UV (352 nm) e visor amarelo. A cor da fluorescência foi expressa a partir do consenso de três ou mais observadores e concluíram que a fluorescência é uma ferramenta que pode auxiliar na identificação de madeiras visualmente semelhantes, uma vez que o mogno se diferenciou das demais por ser não fluorescente, exceto da andiroba.

Pandey et al. (1998) afirmaram que a técnica de espectroscopia de fluorescência tem sido uma ferramenta eficaz para a medição de pequenas quantidades de substâncias químicas, devido à sua alta sensibilidade e seletividade.

Moura (2013) realizou uma análise exploratória de 16 espécies de madeiras tropicais por medidas de fluorescência e resolução de curvas multivariadas e os extrativos foram 
apontados como sendo os maiores responsáveis pela fluorescência em madeira, uma vez que lignina e celulose apresentaram maior fluorescência apenas na região do ultravioleta.

Oliveira et al. (2015) ao avaliarem espectros de fluorescência molecular de três espécies distintas de madeiras, destacaram que a técnica de espectroscopia de fluorescência aliada à construção de um modelo matemático por PLS-DA, parece ser bastante promissora para a discriminação entre espécies de madeiras visualmente semelhantes.

\section{MATERIAL E MÉTODOS}

O presente estudo foi realizado no Laboratório de Produtos Florestais (LPF), do Serviço Florestal Brasileiro (SFB), no Laboratório de Tecnologia da Madeira do Departamento de Engenharia Florestal da Universidade de Brasília (UnB) e no Laboratório de Automação, Quimiometria e Química Ambiental (AQUA) do Instituto de Química da Universidade de Brasília (UnB).

\subsection{OBTENÇÃO DO MATERIAL E PREPARO DOS CORPOS DE PROVA}

Para a realização deste estudo, foram escolhidas as espécies florestais Simarouba amara e Eucalyptus saligna, ambas apresentando baixa específica básica, abaixo de $0,5 \mathrm{~g} / \mathrm{cm}^{3}$, conforme classificação de Melo et al. (1990).

Uma prancha de dimensões 15 x 6 x $300 \mathrm{~cm}$ de Simarouba amara e ripas de Eucalyptus saligna nas dimensões de 8-10 x 4-5 x 150-180 cm foram obtidas no mercado madeireiro de Brasília. Todo o material utilizado para a confecção de corpos de prova, livre de defeitos, foi identificado por especialistas em anatomia de madeira do Laboratório de Produtos Florestais (LPF).

As peças maiores foram aplainadas e os corpos de prova para o ensaio de apodrecimento acelerado foram confeccionados na marcenaria do LPF, nas dimensões 2 x 2 × $1 \mathrm{~cm}$. Um total de 411 corpos de prova foram confeccionados por espécie e, em seguida, lixados com lixa de grã 150 .

Inicialmente todos os corpos de prova foram submetidos à climatização em estufa de circulação forçada de ar a $50{ }^{\circ} \mathrm{C}$ até massa constante, sendo esta monitorada com auxílio de balança eletrônica digital, com precisão de $0,001 \mathrm{~g}$. 


\subsection{DETERMINAÇÃO DA MASSA ESPECÍFICA BÁSICA}

Paralelamente à climatização dos corpos de prova, foi determinada a massa específica básica das espécies em estudo no Laboratório de Engenharia e Física do LPF, de acordo com a norma NBR 11941 (ABNT, 2003a). Para tanto, foram confeccionados 10 corpos de prova, nas dimensões 2 × 2 x $10 \mathrm{~cm}$ e 1,5 x 1,5 x $10 \mathrm{~cm}$ para Simarouba amara e Eucalyptus saligna, respectivamente.

\subsection{DELINEAMENTO DO ESTUDO}

Os tratamentos apresentados na Tabela 5.1 foram definidos combinando-se as espécies de madeiras e os fungos apodrecedores. Foram utilizadas 15 amostras testemunhas (sem fungo) de Simarouba amara e Eucalyptus saligna.

Tabela 5.1 Delineamento experimental.

\begin{tabular}{cccc}
\hline Tratamentos & Espécie de madeira & Fungo apodrecedor & Corpos de prova \\
\hline Testemunha & & Sem fungo & 15 \\
1 & Simarouba amara & Podridão branca & 180 \\
2 & & Podridão parda & 180 \\
\hline Testemunha & & Sem fungo & 15 \\
3 & Eucalyptus saligna & Podridão branca & 198 \\
4 & & Podridão parda & 198 \\
\hline
\end{tabular}

Os ensaios de apodrecimento acelerado, colorimetria, espectroscopia no infravermelho médio e fluorescência molecular foram realizados para cada amostra dos tratamentos definidos.

\subsection{ENSAIO DE APODRECIMENTO ACELERADO}

O ensaio de apodrecimento acelerado foi realizado na Área de Biodegradação e Preservação da Madeira do LPF, seguindo a metodologia da norma ASTM D 2017 (AMERICAN SOCIETY FOR TESTING AND MATERIALS - ASTM, 2005).

Os fungos xilófagos utilizados no ensaio foram de podridão branca (Trametes versicolor (L.; Fr.) Pilat) e podridão parda (Gloeophyllum trabeum (Pers.; Fr.) Karte), ambos provenientes da micoteca do LPF. 


\subsubsection{Preparo do substrato}

O solo utilizado como substrato para o ensaio de apodrecimento acelerado foi obtido na Fazenda Água Limpa, pertencente à Universidade de Brasília, sendo um latossolo vermelho, de horizonte B. Foi realizada a correção de $\mathrm{pH}$ do solo para aproximadamente 6,0, utilizando-se calcário dolomítico PRNT (66\%), na proporção de 65 g para cada $20 \mathrm{~kg}$ de solo. Além disso, foi calculada a capacidade de retenção de água no solo, a partir da qual foi determinada a quantidade de água a ser colocada nos frascos de vidro.

O substrato preparado foi acondicionado em frascos de vidro de $250 \mathrm{~mL}$ e tampa de plástico rosqueável.

Em cada frasco, foram adicionados $90 \mathrm{~g}$ de solo com $\mathrm{pH}$ corrigido e $34 \mathrm{~mL}$ de água destilada. Além disso, cada frasco recebeu uma placa suporte de madeira de alburno de Cecropia spp. ou Pinus spp. (espécies altamente susceptíveis aos fungos xilófagos), sobre o solo, nas dimensões de $0,3 \times 2,9 \times 3,5 \mathrm{~cm}$. A função da placa suporte foi servir de substrato para $\mathrm{o}$ desenvolvimento inicial dos fungos.

Em seguida, os frascos de vidro foram autoclavados a $120^{\circ} \mathrm{C}$ e pressão de $1 \mathrm{~atm}$ por 40 minutos, e acondicionados em sala de incubação, a $27{ }^{\circ} \mathrm{C}$ e $70 \%$ de umidade relativa, a fim de monitorar se há contaminações no experimento.

\subsubsection{Repicagem dos fungos e inoculação dos frascos de vidro}

Foi preparado um meio de cultura com $45 \mathrm{~g}$ de extrato de malte para cada $3000 \mathrm{~mL}$ de água destilada. Em seguida, o meio de cultura preparado foi agitado, autoclavado a $120{ }^{\circ} \mathrm{C}$ e pressão e 1 atm, durante 20 minutos e levado à sala de incubação, onde permaneceu por uma semana para monitorar o surgimento de contaminação.

A repicagem dos fungos (Figura $5.1 \mathrm{~b}$ ) foi realizada assepticamente em capela de fluxo laminar, obtendo-se inóculos de aproximadamente $1 \mathrm{~cm}^{2}$, contendo micélios do fungo, que foram adicionados ao meio de cultura líquida preparado. Posteriormente, os erlenmeyers foram levados a uma mesa agitadora, para homogeneização e aeração do meio de cultura, durante 48 horas. Após este período, os frascos foram encaminhados à sala de incubação, a temperatura de $27^{\circ} \mathrm{C}$ e umidade relativa de $70 \%$, onde permaneceram por 2 meses, visando o desenvolvimento dos fungos. 


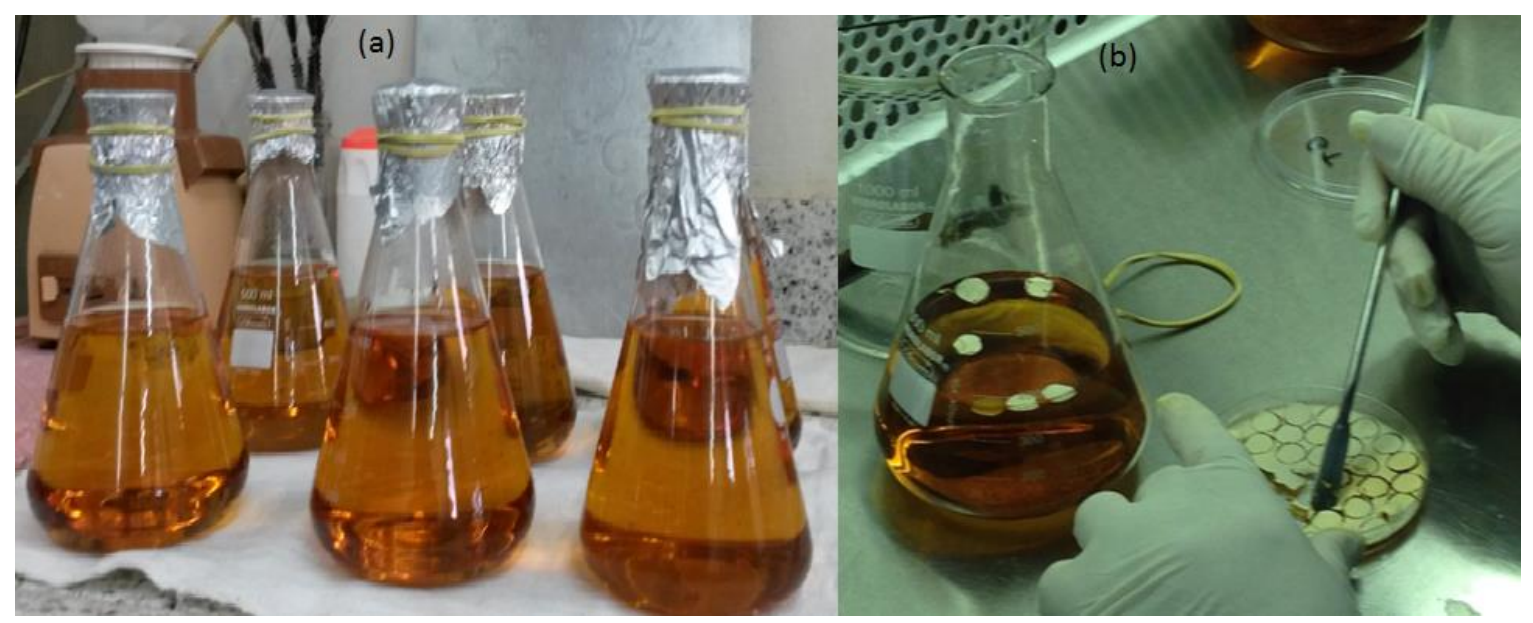

Figura 5.1 (a) Erlenmeyer contendo meio de cultura líquido; (b) Processo de repicagem dos fungos.

Após o desenvolvimento dos fungos, o meio de cultura preparado foi homogeneizado, utilizando-se um liquidificador, visando uma melhor distribuição dos micélios dos fungos no meio de cultura líquida, para posterior inoculação.

A inoculação dos frascos de vidro (Figura 5.2) também foi realizada assepticamente em capela de fluxo laminar, com o auxílio de um pipetador, adicionando-se $3 \mathrm{~mL}$ de meio de cultura líquida contendo os micélios do fungo, sobre parte da placa suporte e o solo. Em seguida, os frascos foram novamente encaminhados à sala de incubação a temperatura de 27 ${ }^{\circ} \mathrm{C}$ e umidade relativa de $70 \%$, onde permaneceram por 2 meses, objetivando o desenvolvimento homogêneo do fungo sobre a placa suporte.

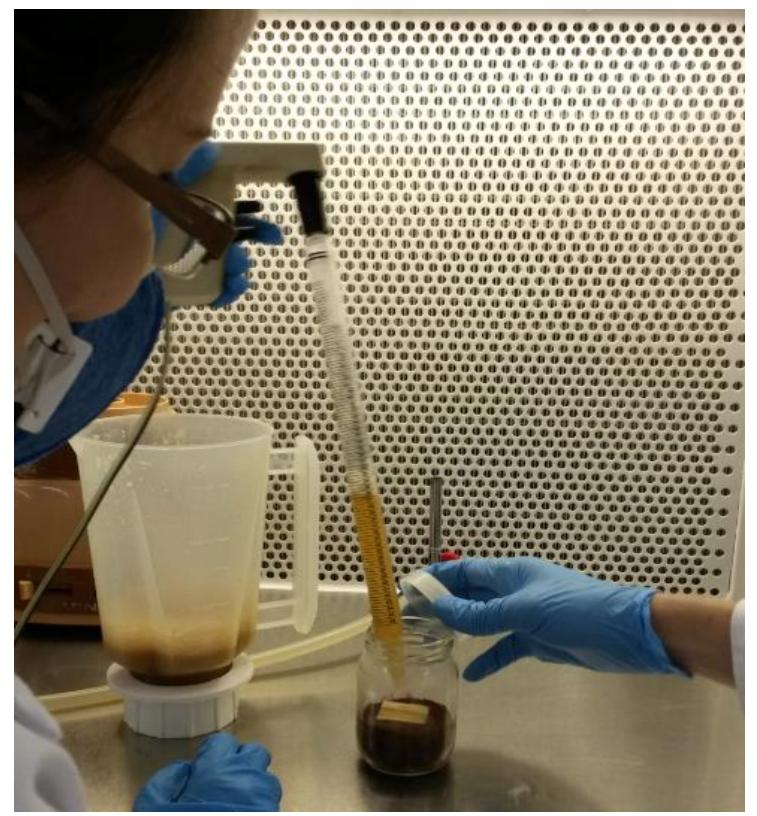

Figura 5.2 Processo de inoculação dos frascos de vidro. 


\subsubsection{Preparo dos corpos de prova para ensaio de apodrecimento acelerado}

Os corpos de prova foram climatizados em estufa de circulação forçada de ar a $50{ }^{\circ} \mathrm{C}$ até atingirem massa constante, sendo esta, então, considerada a massa inicial. Após o período de climatização, e também em cada pesagem intermediária até massa constante, os corpos de prova foram colocados em dessecador contendo sílica gel, durante 30 minutos, para estabilização com a temperatura e umidade do meio externo. Em seguida, foram pesados com auxílio de balança eletrônica, com precisão de 0,001 g.

A esterilização dos corpos de prova foi feita em autoclave a $120{ }^{\circ} \mathrm{C}$, durante 40 minutos, visando a eliminação de contaminantes indesejados no experimento.

\subsubsection{Início do ensaio de apodrecimento acelerado}

Após o desenvolvimento inicial dos fungos na placa suporte durante 2 meses, os corpos de prova foram colocados assepticamente, um para cada frasco de vidro, em câmara de fluxo laminar e com o auxílio de uma pinça, sobre as placas suporte, entrando em contato direto com o fungo. Posteriormente, os frascos foram novamente levados à sala de incubação (Figura 5.3), com temperatura de $27^{\circ} \mathrm{C}$ e umidade relativa de $70 \%$, onde permaneceram por um período de 12 semanas de execução do experimento.

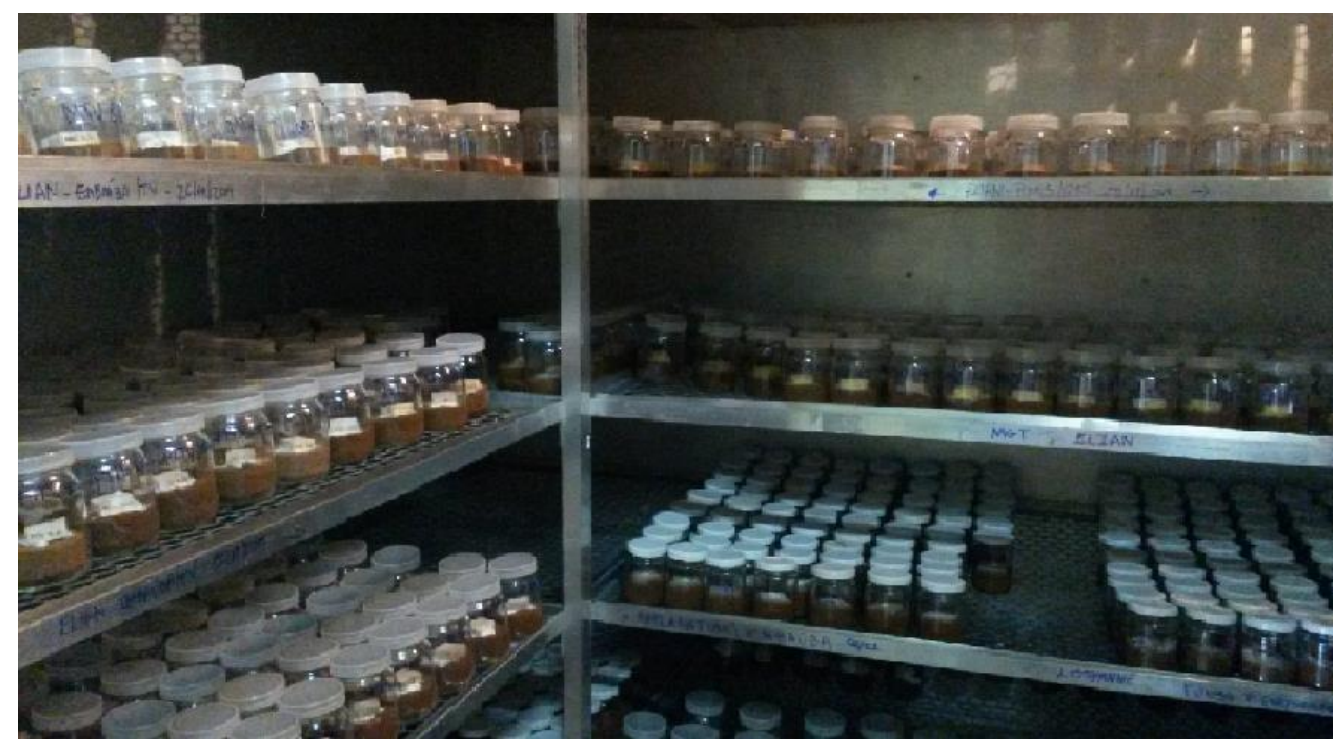

Figura 5.3 Câmara climática no período de execução do projeto.

\subsubsection{Retirada dos corpos de prova}

Semanalmente, durante 12 semanas, foram retirados 15 corpos de prova de cada espécie de madeira e fungo estudado. 
Após a retirada semanal (Figura 5.4 a), os corpos de prova passaram por processo de limpeza e remoção do excesso de micélios dos fungos sobre a superfície da madeira (Figura 5.4 b), com o auxílio de uma escova de cerdas macias, e levados à estufa de circulação forçada de ar para nova climatização a $50{ }^{\circ} \mathrm{C}$ até atingirem massa constante.

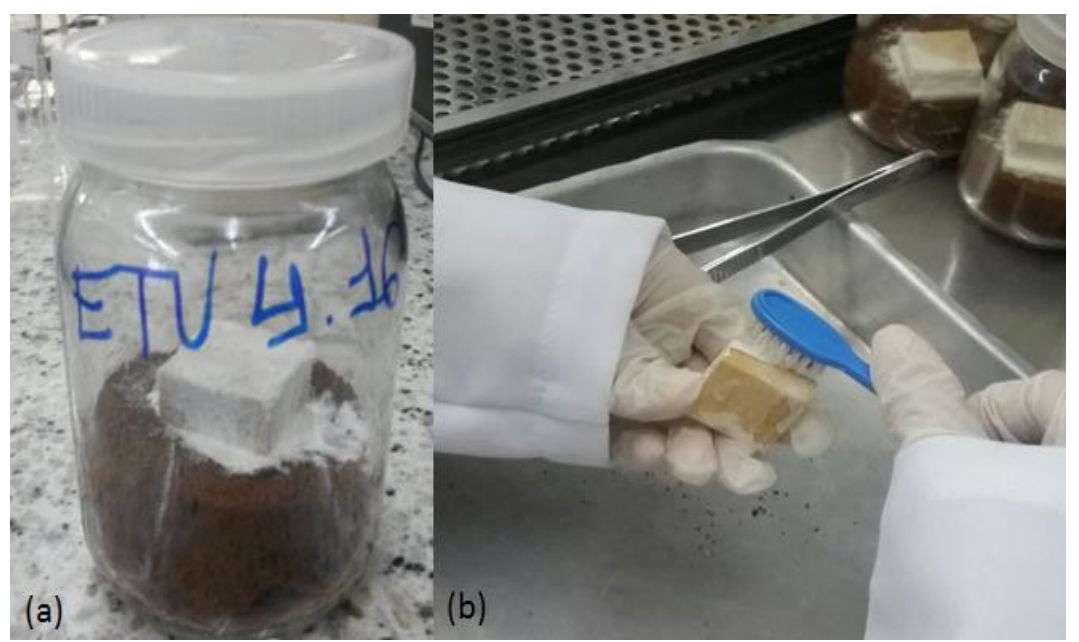

Figura 5.4 (a) Detalhe de corpo de prova ao ser retirado da câmara climática; (b) Processo de limpeza dos corpos de prova.

\subsubsection{Perda de massa}

A resistência natural de cada corpo de prova foi avaliada semanalmente durante as 12 semanas previstas para o estudo, por meio da sua perda de massa, calculada segundo a Equação 5.1.

$$
P M=\frac{M_{i}-M_{f}}{M_{i}} * 100
$$

Em que: $P M=$ perda de massa $(\%) ; M_{i}=$ massa inicial $(\mathrm{g}) ; M_{f}=$ massa final $(\mathrm{g})$.

\subsection{COLORIMETRIA}

O ensaio para determinação da cor da madeira pós-ataque dos fungos foi realizado no Laboratório de Tecnologia da Madeira do Departamento de Engenharia Florestal da Universidade de Brasília.

Os parâmetros colorimétricos foram determinados utilizando-se a espectrofotocolorimetria, uma técnica de reflectância difusa no intervalo visível do espectro eletromagnético, seguindo a metodologia adotada por Gonçalez (1993). 
Com o auxílio do espectrofotocolorímetro Color Eye-XTH-X-rite (Figura 5.5), foram obtidos os parâmetros colorimétricos. Este aparelho apresenta uma resolução de $3 \mathrm{~nm}$ e possui uma esfera integradora de refletância difusa. Além disso, foi utilizado o iluminante D65, uma lâmpada de xenônio que simula a radiação solar diurna, com um ângulo de observação de $10^{\circ}$ em temperatura ambiente. O aparelho foi calibrado anteriormente à obtenção dos dados, seguindo as referências fornecidas pelo equipamento, uma com L*= 100 (branco total) e outra com $\mathrm{L}^{*}=0$ (preto total).

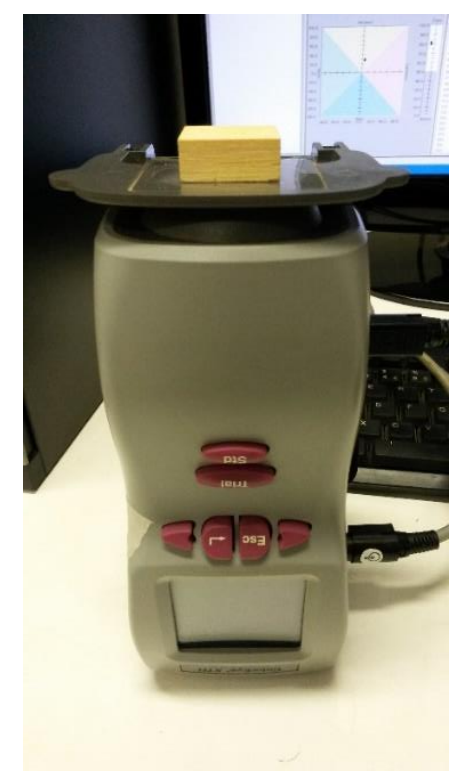

Figura 5.5 Espectrofotocolorímetro Color Eye-XTH-X-rite.

Anteriormente à obtenção dos dados, todas as amostras foram previamente climatizadas em estufa a $50^{\circ} \mathrm{C}$ até massa constante. A metodologia estabelecida pelo sistema CIELAB 1976 (CAMARGOS; GONÇALEZ, 2001) foi seguida e os parâmetros colorimétricos obtidos para as amostras selecionadas de Simarouba amara e Eucalyptus saligna foram: L* (claridade ou luminosidade), coordenadas $a^{*}$ (matizes do eixo vermelho - verde), b* (matizes do eixo amarelo - azul), C (saturação) e h* (ângulo de tinta). A variação total da cor (Equação 5.2) foi determinada seguindo a norma ASTM D 2244 - 09a (ASTM, 2009).

$$
\Delta E=\sqrt{\Delta L^{*^{2}}+\Delta a^{*^{2}}+\Delta b^{*^{2}}}
$$

Em que: $\Delta=$ variação entre uma leitura inicial e outra final ou parcial.

Em cada corpo de prova foram realizadas 5 leituras da cor, utilizando-se o valor médio destas medições para determinar a curva de refletância de cada amostra. 


\subsection{ESPECTROSCOPIA DE INFRAVERMELHO MÉDIO}

Os ensaios de espectroscopia na região do infravermelho médio (MIR) para determinação das alterações químicas na madeira foram realizados no Setor de Química, Adesivos e Borracha Natural do LPF/SFB.

Com o auxílio de um espectrofotômetro com transformada de Fourier, da marca Bruker e modelo Tensor 37 (Figura 5.6), foram obtidos os espectros das amostras. Foram realizados testes utilizando o dispositivo de reflectância difusa (DRIFT) e o de reflectância total atenuada (ATR), apresentados nas Figuras 5.7 e 5.8, a fim de determinar qual apresenta a metodologia mais prática e de melhor resultado. Para tais testes, utilizou-se madeira não atacada, sólida e em pó, para os dois tipos de dispositivos móveis.

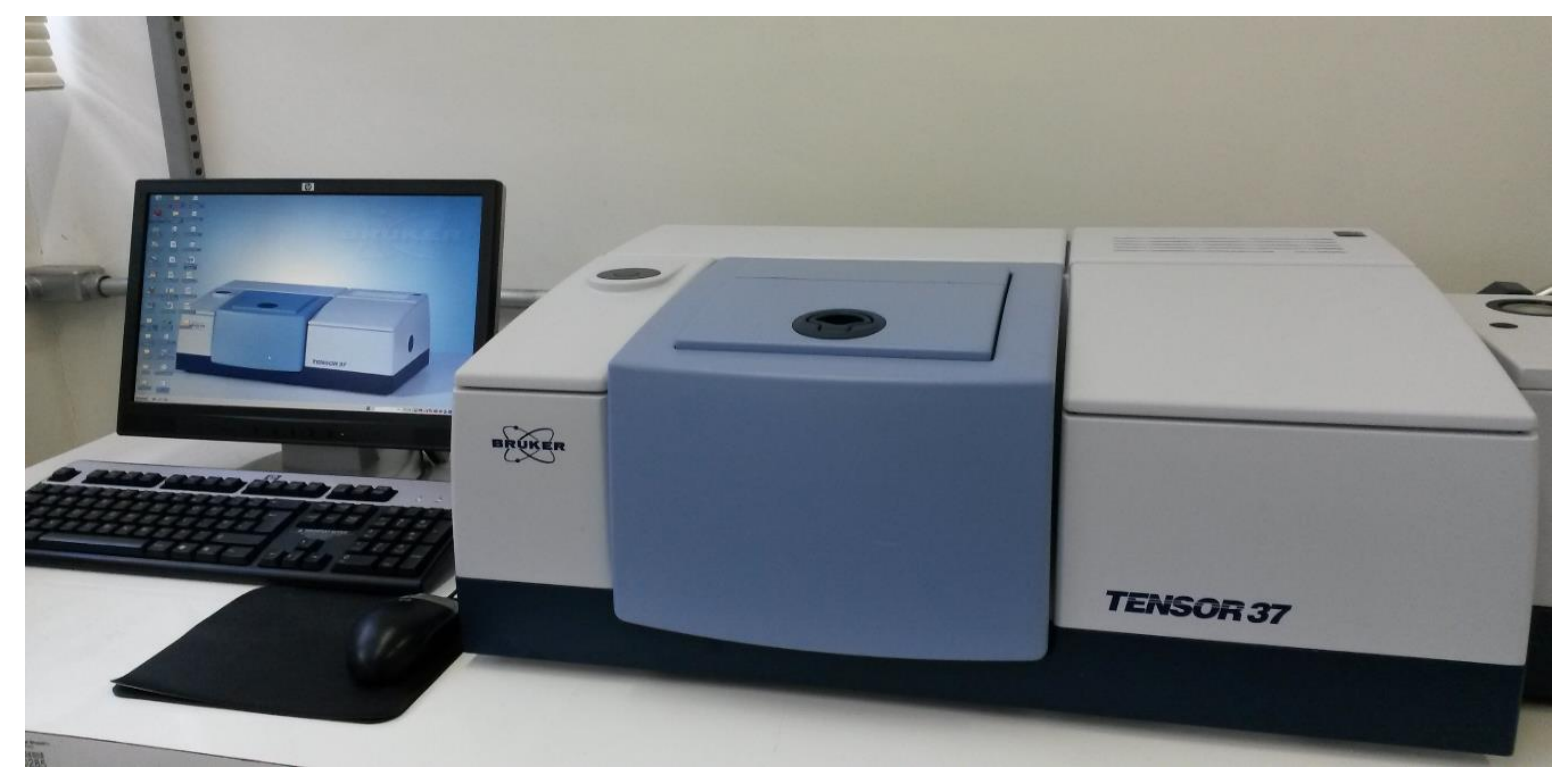

Figura 5.6 Espectrofotômetro Tensor 37, Bruker.

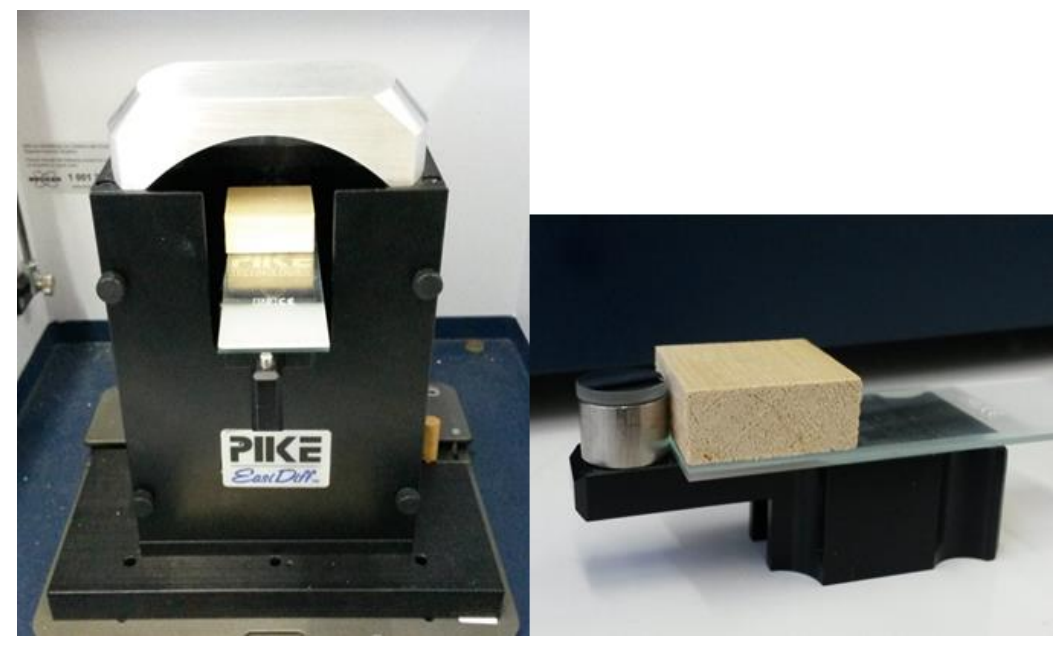

Figura 5.7 Dispositivo de reflectância difusa (DRIFT). 


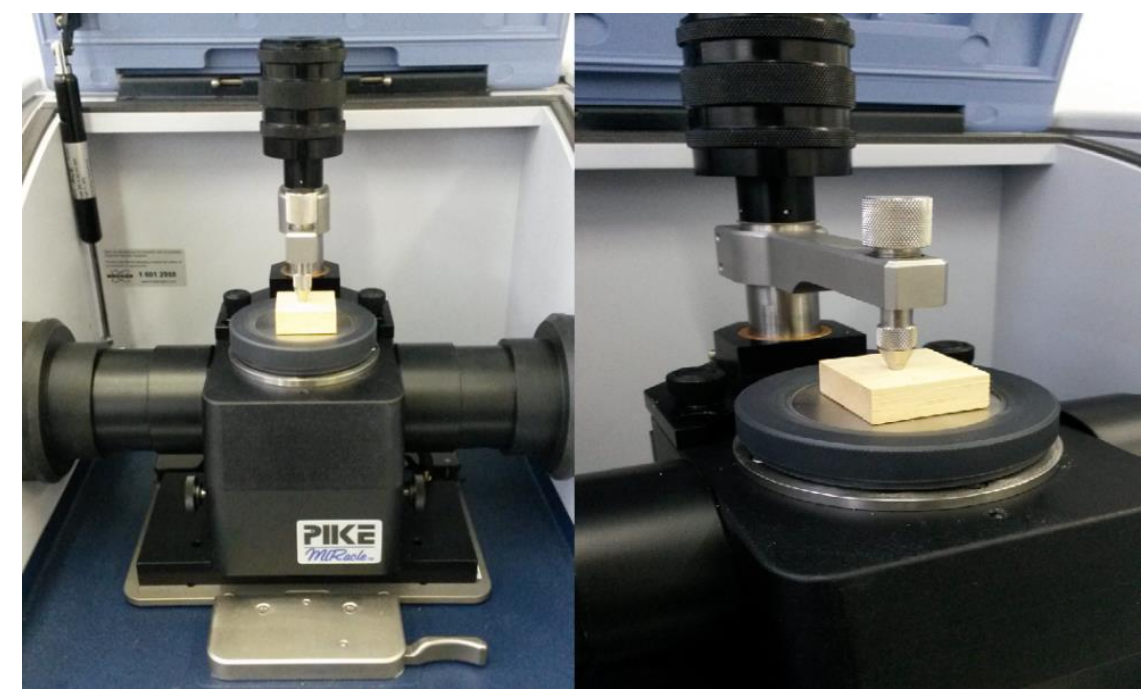

Figura 5.8 Dispositivo de reflectância total atenuada (ATR).

Os espectros apresentados nas Figuras 5.9 e 5.10, obtidos com auxílio de ambos os dispositivos. Em função da praticidade do método da reflectância difusa (DRIFT), onde pode ser utilizado o corpo de prova sólido, esta metodologia foi a escolhida para execução deste trabalho.

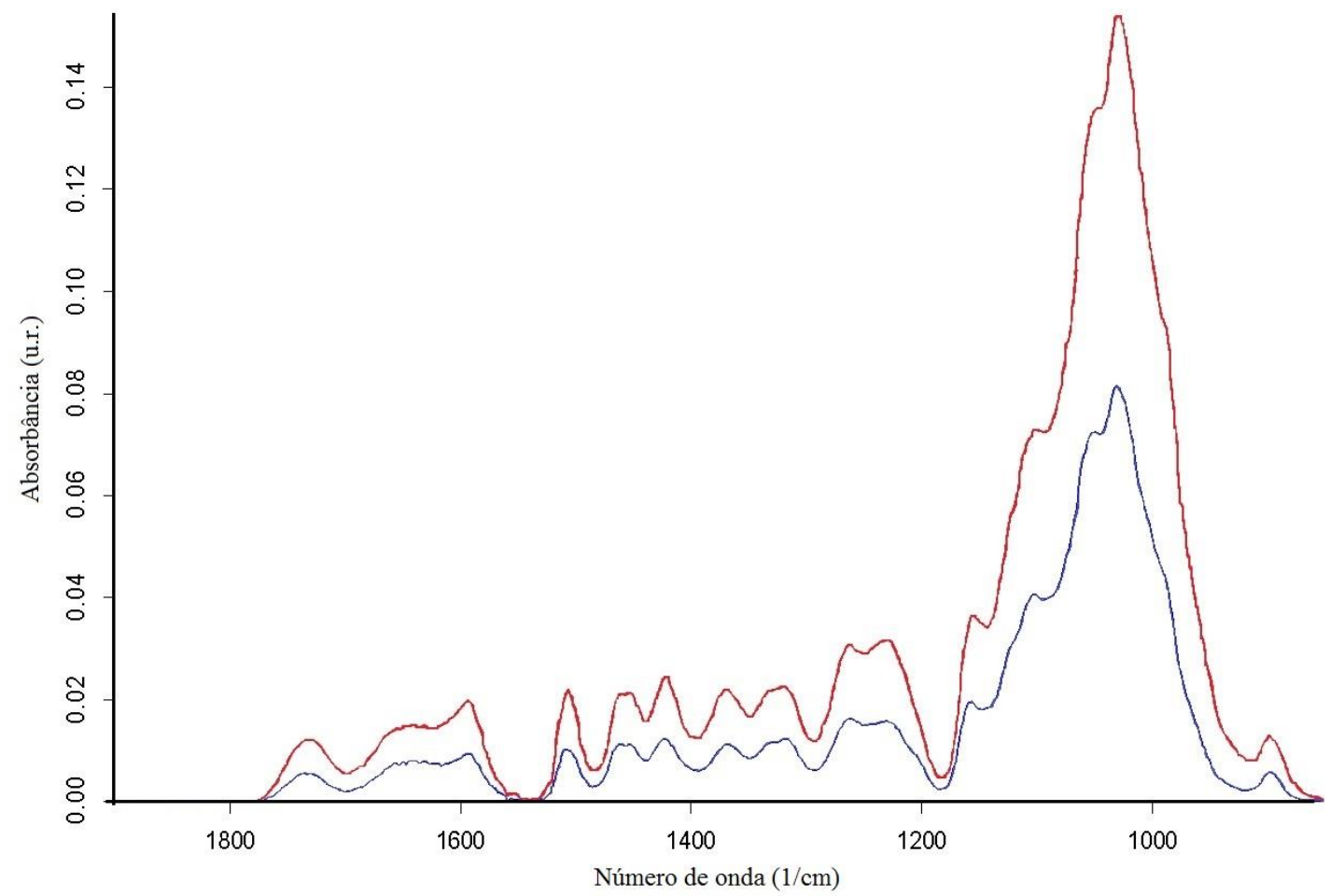

Figura 5.9 Espectros de ATR-MIR de madeira sólida (azul) e em pó (vermelho). 


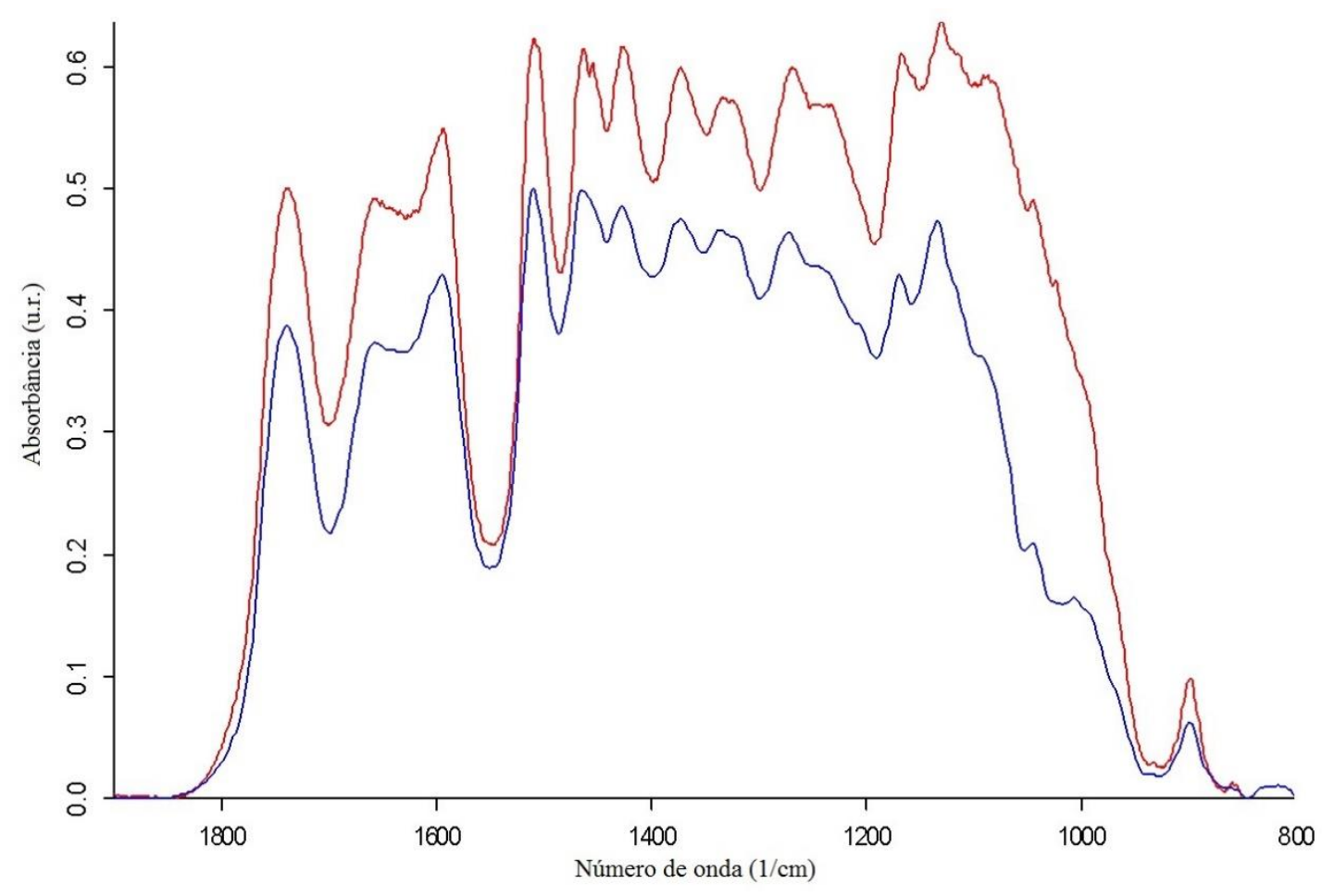

Figura 5.10 Espectros de DRIFT-MIR de madeira sólida (azul) e em pó (vermelho).

Todos os ensaios foram realizados em sala climatizada, a fim de evitar ou minimizar a influência do ambiente na coleta dos dados. Além disso, todas as amostras foram previamente climatizadas em estufa a $50^{\circ} \mathrm{C}$ até massa constante.

O espectro de fundo (background), reflexão total da radiação infravermelha média, foi obtido antes dos espectros dos corpos de prova, utilizando uma pequena estrutura de superfície espelhada fornecida pelo dispositivo DRIFT. A cada medição de 5 corpos de prova, era realizado um novo background, visando diminuir a interferência do gás carbônico e da água durante o processo de medição dos espectros.

Foi obtido um espectro para cada corpo de prova, na face radial, sendo feitas 64 varreduras (scans) por espectro, utilizando resolução de $4 \mathrm{~cm}^{-1}$ e faixa espectral entre 4000 a $850 \mathrm{~cm}^{-1}$. Ao final, a média dessas varreduras era correspondente ao espectro da amostra a ser analisada.

O software utilizado para manipulação e análise dos dados foi o OPUS 6.5. Foram realizados os seguintes procedimentos: definição do fingerprint entre 1900 a $800 \mathrm{~cm}^{-1}$, correção de linha de base, aplicação de ferramenta de individualização das bandas de interesse e medição da área da banda de interesse. Todo o processo até obtenção dos dados a serem analisados está apresentado nas Figuras 5.11 e 5.12. 


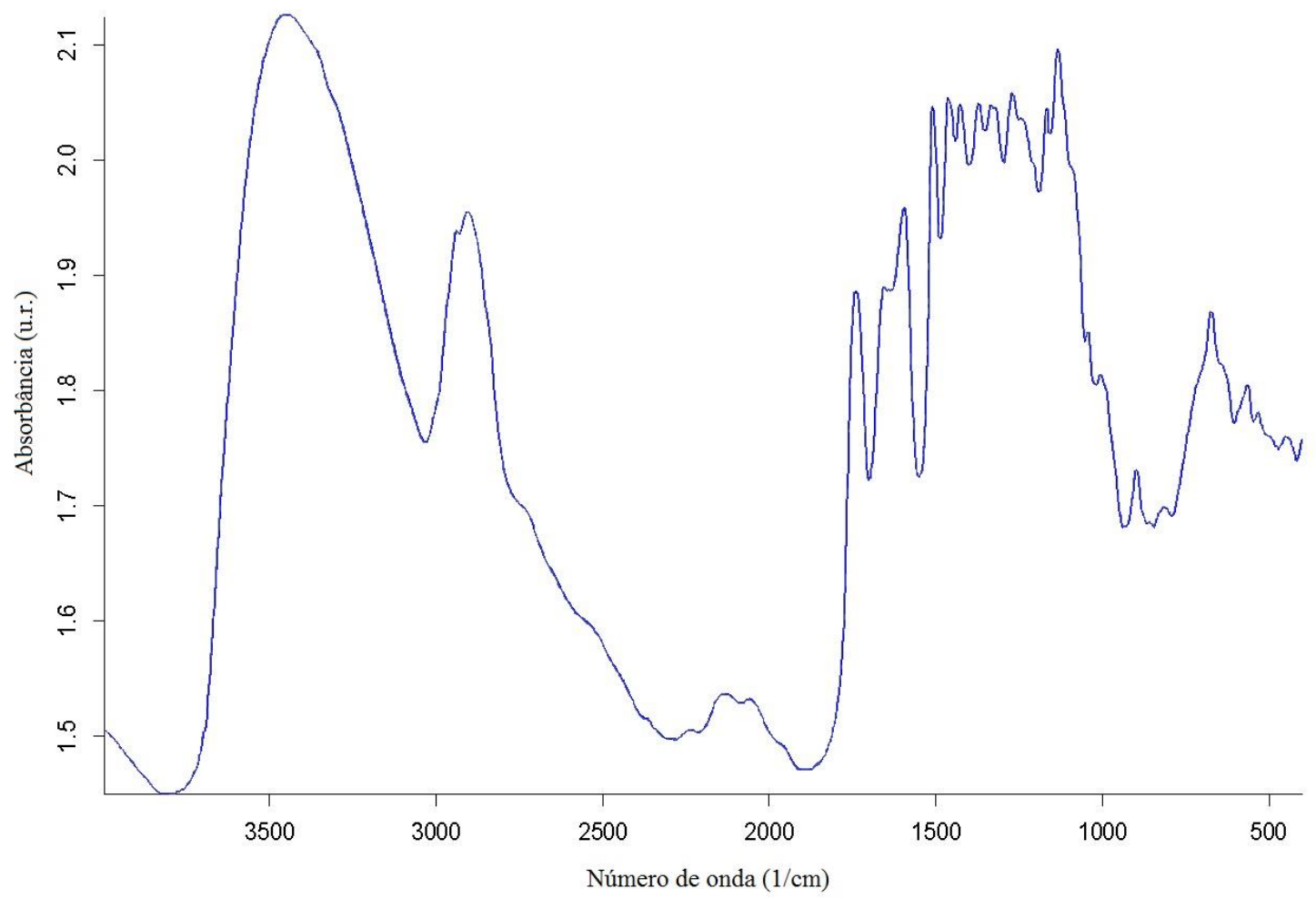

Figura 5.11 Espectro de DRIFT-MIR não manipulado.

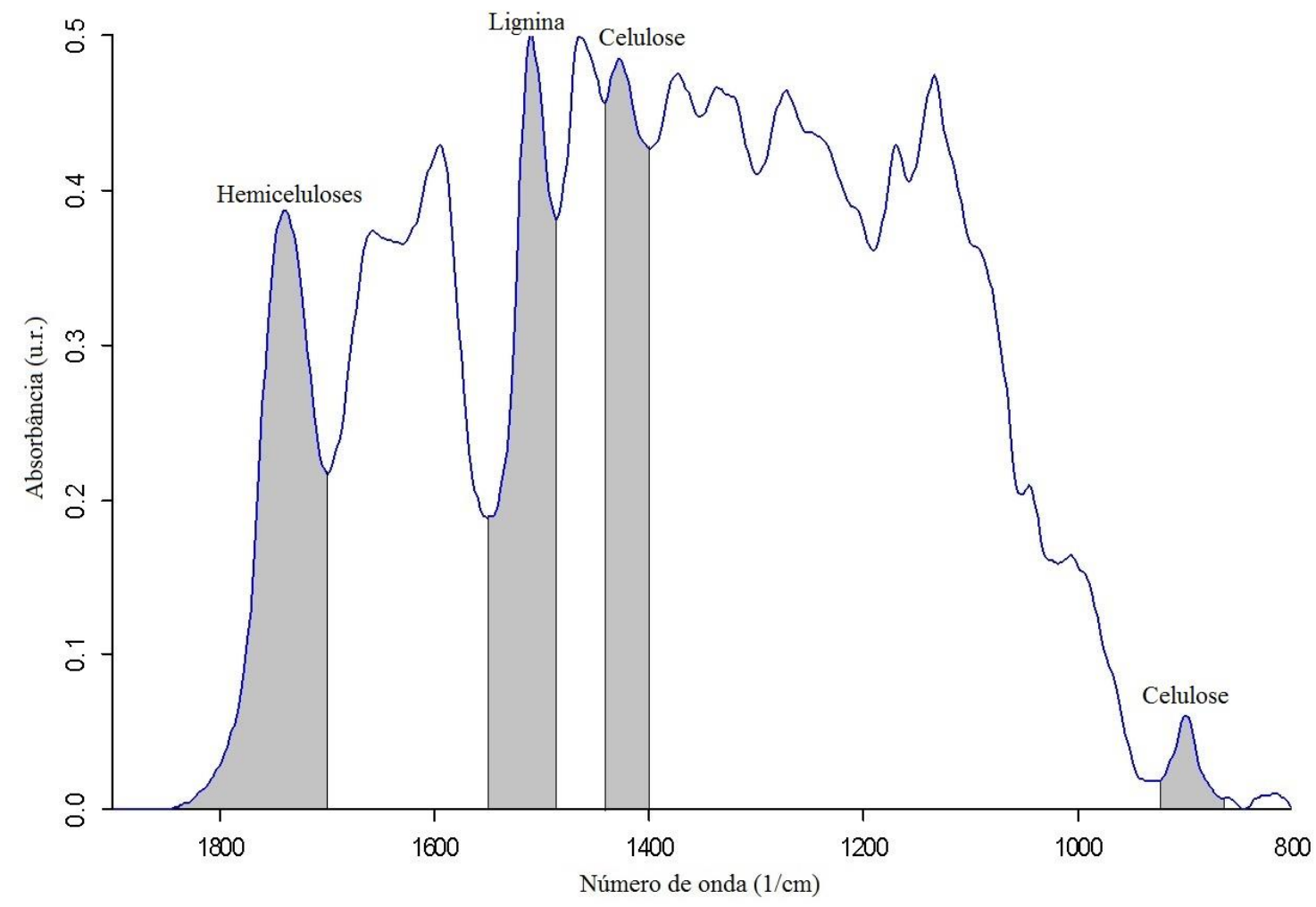

Figura 5.12 Espectro de DRIFT-MIR manipulado: fingerprint definido, alinhamento de base, seleção de bandas de interesse e definição de área para medição de bandas. 


\subsection{DETERMINAÇÃO DA FLUORESCÊNCIA MOLECULAR}

O ensaio de fluorescência molecular foi realizado no Laboratório de Automação, Quimiometria e Química Ambiental (AQUA) do Instituto de Química da Universidade de Brasília.

As amostras retiradas a cada semana foram inicialmente climatizadas em estufa a $50{ }^{\circ} \mathrm{C}$ até atingir massa constante. A face escolhida para ser analisada foi a radial, baseando-se em testes anteriores de fluorescência em espectrofluorímetro, que determinaram ser essa a face que apresentava os maiores níveis de intensidade de fluorescência (MOURA, 2013). A face radial não foi lixada para não perder as características da superfície deteriorada pelos fungos.

Os espectros foram obtidos com auxílio de um espectrofluorímetro da marca Varian, modelo Cary Eclipse (Figura 5.13), com aberturas em ambos os monocromadores de excitação e emissão de $5 \mathrm{~nm}$, varredura no modo médio, ganho da fotomultiplicadora no nível médio e com a radiação ultravioleta fornecida por uma lâmpada de xenônio de $50 \mathrm{~W}$

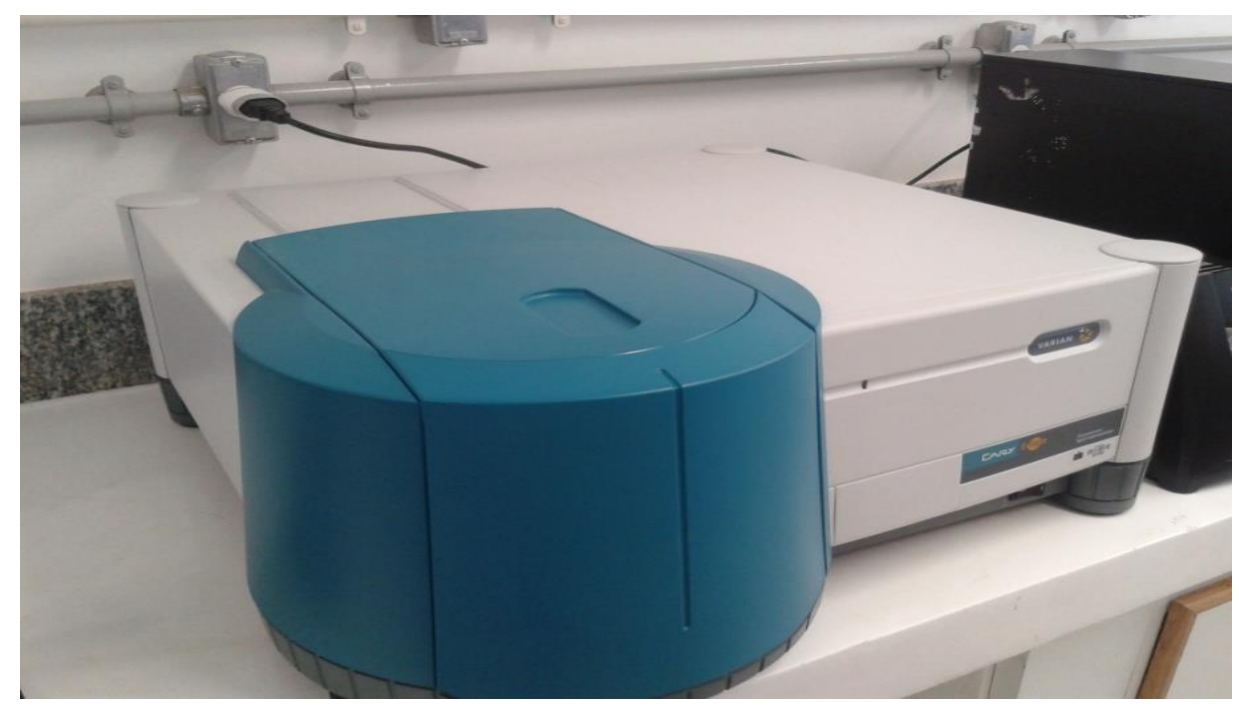

Figura 5.13 Espectrofluorímetro Cary Eclipse, Varian.

A Figura 5.14 apresenta o dispositivo utilizado como suporte das amostras sólidas que pode ser ajustado em três direções com a finalidade de obter-se a maior intensidade de fluorescência emitida. 


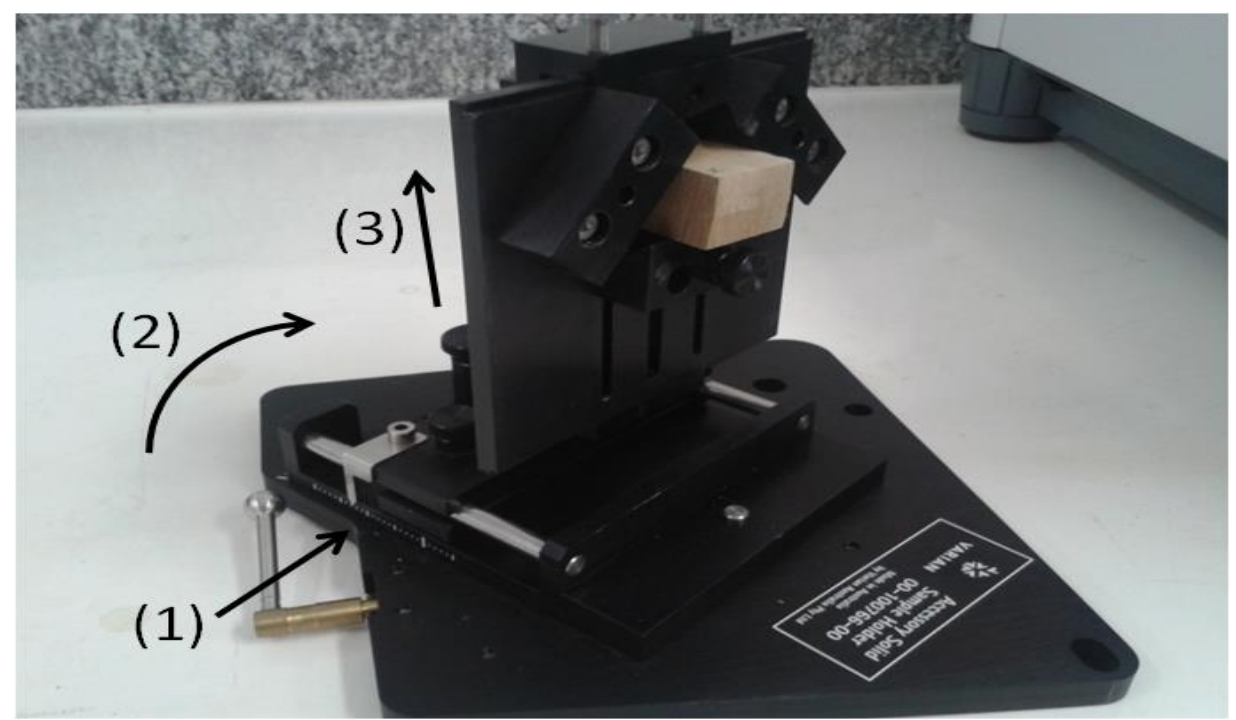

Figura 5.14 Dispositivo utilizado para análise de amostras sólidas. Fonte: Moura (2013).

Foram feitas varreduras no comprimento de onda de excitação de $370 \mathrm{~nm}$ e obtidos os espectros de emissão das amostras entre $380 \mathrm{~nm}$ e $660 \mathrm{~nm}$.

Em seguida, visando obter informação química relevante para a avaliação da resistência da madeira e, mediante emprego do software Matlab® versão R2012b, foram realizadas as seguintes manipulações (pré-processamentos) nos espectros: correção de desvio de linha de base (SNV, do inglês Standard Normal Variate) e exclusão do espectro médio (Mean Center). A análise estatística dos dados de fluorescência obtidos foi realizada por meio de: Análise Classificatória Hierárquica Aglomeradora, pelo critério do método de Ward; Análise de Componentes Principais (PCA, do inglês Principal Components Analysis); e Análise de Variância Fatorial.

\subsection{ANÁLISE ESTATÍSTICA}

A análise dos dados de perda de massa, parâmetros colorimétricos, químicos e fluorescência foi realizada com o auxílio do software ASSISTAT 7.7 Beta, por meio de análise de variância fatorial e comparação de médias dos tratamentos pelo teste de Scott-Knott ao nível de 5\% de significância. Também foram realizadas correlações de Pearson a 1\% e 5\% de significância.

\section{RESULTADOS E DISCUSSÃO}

\subsection{PERDA DE MASSA}

A massa específica básica obtida para a madeira de Simarouba amara foi $0,38 \mathrm{~g} / \mathrm{cm}^{3}$ e para a madeira de Eucalyptus saligna foi $0,43 \mathrm{~g} / \mathrm{cm}^{3}$. 
As Figuras 6.1 e 6.2 e o Apêndice A apresentam os valores médios e os desvios padrões da perda de massa observada após o período de exposição das amostras de Simarouba amara e Eucalyptus saligna aos fungos Trametes versicolor (podridão branca) e Gloeophyllum trabeum (podridão parda), além da classificação quanto à resistência natural, segundo a ASTM D 2017.

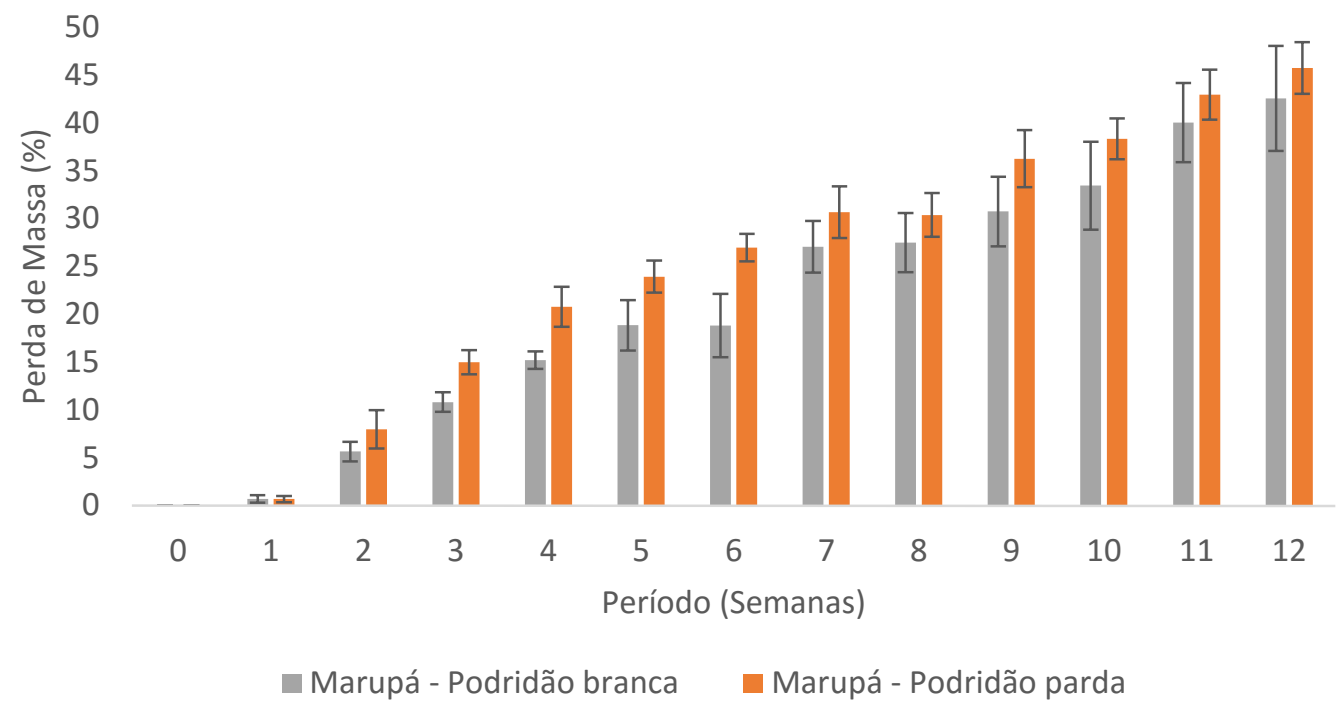

Figura 6.1 Perda de massa semanal da madeira de Simarouba amara após exposição aos fungos apodrecedores Trametes versicolor e Gloeophyllum trabeum.

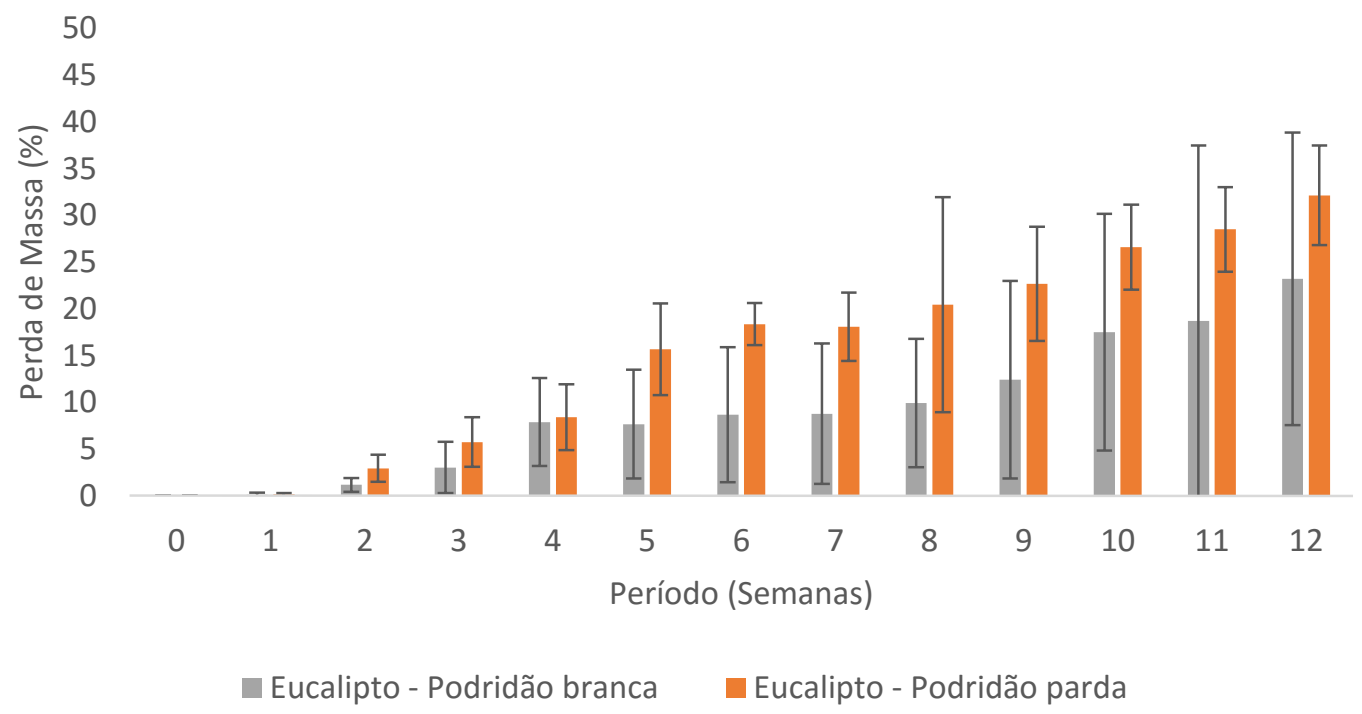

Figura 6.2 Perda de massa semanal da madeira de Eucalyptus saligna após exposição aos fungos apodrecedores Trametes versicolor e Gloeophyllum trabeum. 
A partir da análise do teste de médias, verificou-se que, dentro de uma mesma espécie de madeira e mesmo período de ataque, houve diferença significativa na perda de massa provocada pelos fungos apodrecedores, com exceção das semanas 1, 11 e 12 para ambas as espécies de madeira.

Em média, a madeira de Simarouba amara perdeu 42,54\% e 45,71\% de sua massa inicial ao ser submetida aos fungos de podridão branca e parda, respectivamente, após 12 semanas de ensaio. Após este mesmo período, a madeira de Eucalyptus saligna apresentou-se mais resistente a ambos os fungos, perdendo $23,19 \%$ e 32,12\% de sua massa inicial após o ataque de podridão branca e parda, respectivamente.

Constatou-se então que o mecanismo de ação do fungo de podridão parda Gloeophyllum trabeum proporcionou perda de massa superior à verificada para o fungo de podridão branca Trametes versicolor, além de colapso estrutural expressivo (Anexo D). Segundo Eaton e Hale (1993), o fungo de podridão parda causa rápida despolimerização dos polissacarídeos da parede celular por uma gama de enzimas, provocando sérias consequências com respeito às propriedades de resistência mecânica da madeira.

Stangerlin et al. (2013) estudaram a madeira de Simarouba amara, a qual apresentou 2,49\% de extrativos em sua composição química, enquanto que a madeira de Eucalyptus saligna, que teve a sua composição química analisada por Guimarães et al. (2013), apresentou 7,87\% de extrativos. Portanto, a diferença na perda de massa observada neste estudo para ambas as espécies florestais submetidas aos dois fungos apodrecedores, pode ser explicada pela maior massa específica apresentada pela madeira de eucalipto em relação ao marupá e/ou pelo teor de extrativos (presente em maior quantidade na madeira de Eucalyptus saligna), uma vez que a presença destes componentes secundários nas paredes celulares confere à madeira uma maior resistência natural (OLIVEIRA et al., 2005).

Quanto à classificação de resistência biológica proposta pela norma ASTM D 2017, ao final do ensaio de apodrecimento acelerado, a madeira de Simarouba amara foi classificada como não resistente ao ataque de Gloeophyllum trabeum e moderadamente resistente ao ataque de Trametes versicolor. Já a madeira de Eucalyptus saligna foi classificada como moderadamente resistente ao ataque de Gloeophyllum trabeum e resistente ao ataque de Trametes versicolor.

Costa (2009), Stangerlin (2012) e Freitas et al. (2012) classificaram a madeira de marupá como não resistente ao ataque de Gloeophyllum trabeum e Trametes versicolor. Os 
resultados registrados por estes autores estão de acordo com os encontrados neste estudo apenas para o fungo de podridão parda. Carneiro et al. (2009) classificaram a madeira de marupá como moderadamente resistente ao ataque de podridão branca. Esta classificação está de acordo com o resultado obtido no presente estudo.

Ao estudar a resistência natural da madeira de Eucalyptus saligna a fungos apodrecedores, CSIRO (1997) a classificou como moderadamente durável a durável.

Silva et al. (2014), ao submeterem a madeira de Eucalyptus grandis aos fungos apodrecedores Trametes versicolor e Gloeophyllum trabeum, observaram uma perda de massa bem maior provocada pela podridão parda, confirmando os resultados deste estudo em relação aos fungos utilizados.

A Tabela 6.1 apresenta os valores de correlação entre a perda de massa e o período de exposição das madeiras aos fungos apodrecedores.

Tabela 6.1 Correlação entre a perda de massa e o período de exposição das madeiras aos fungos Trametes versicolor e Gloeophyllum trabeum.

\begin{tabular}{lclcc}
\hline & \multicolumn{2}{c}{ Simarouba amara } & \multicolumn{2}{c}{ Eucalyptus saligna } \\
\hline & PM\% - TV & PM\% - GT & PM\% - TV & PM\% - GT \\
Período (Semanas) & $0,99 * *$ & $0,99 * *$ & $0,97 * *$ & $0,99 * *$ \\
\hline
\end{tabular}

Em que: PM\%-TV= perda de massa da madeira após ataque de Trametes versicolor; PM\%$\mathrm{GT}=$ perda de massa da madeira após ataque de Gloeophyllum trabeum; **= significativo a $1 \%$.

Os altos valores positivos e significativos das correlações indicam que a perda de massa ocorrida está estritamente ligada ao período de exposição da madeira aos fungos. Stangerlin (2012) também observou correlações altas para a madeira de Simarouba amara.

Como o fator tempo é quantitativo, houve a necessidade de realizar uma análise de regressão para ver o quanto este fator influencia na variável perda de massa. Os modelos estatísticos gerados estão apresentados nas Figuras 6.3 e 6.4 . 


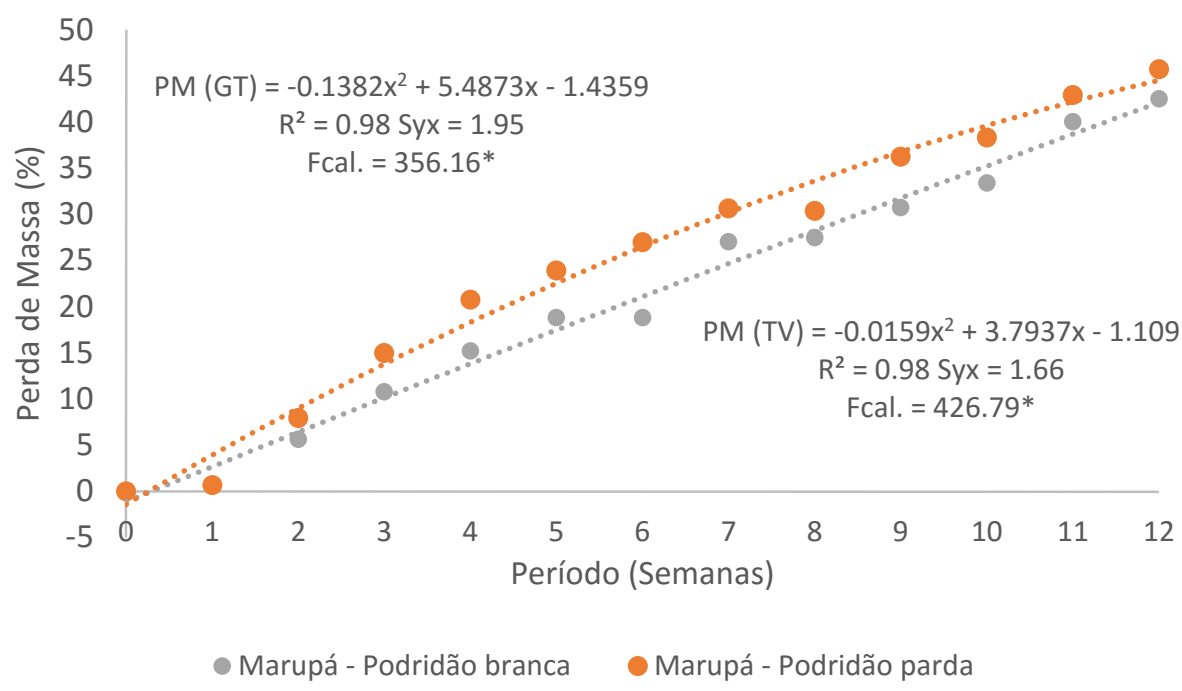

Figura 6.3 Modelo estatístico gerado para predição da perda de massa da madeira de Simarouba amara em função do período de ataque dos fungos Trametes versicolor e Gloeophyllum trabeum.

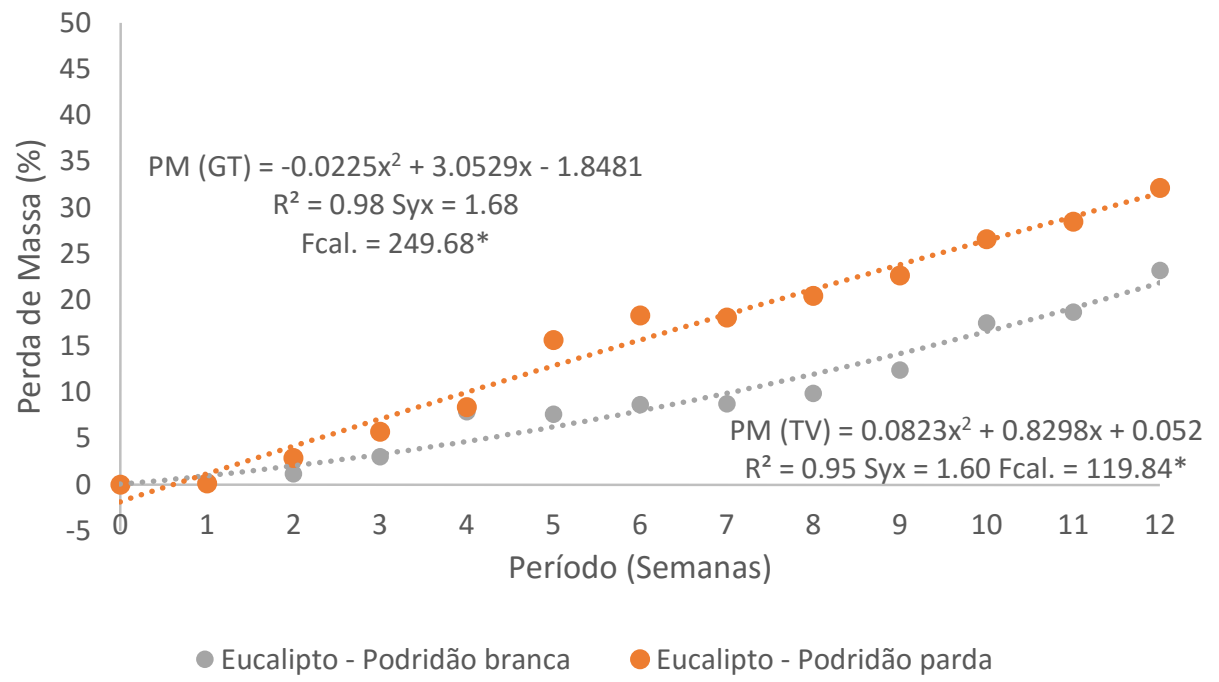

Figura 6.4 Modelo estatístico gerado para predição da perda de massa da madeira de Eucalyptus saligna em função do período de ataque dos fungos Trametes versicolor e Gloeophyllum trabeum.

Ao analisar os parâmetros estatísticos ( $\mathrm{R}^{2}$., Syx e F calculado), verificou-se que os modelos gerados foram bem ajustados e significativos a $5 \%$. O alto valor de $\mathrm{R}^{2}$ ajustado nos permite inferir que as equações ajustadas conseguem explicar mais de $95 \%$ da variabilidade da perda de massa em função do período de exposição da madeira aos fungos apodrecedores. 


\subsection{ANÁLISE COLORIMÉTRICA}

As Figuras 6.5 e 6.6 e os Apêndice B e C apresentam os valores médios e os desvios padrões obtidos a partir dos parâmetros colorimétricos das madeiras de Simarouba amara e Eucalyptus saligna, após exposição aos fungos Trametes versicolor e Gloeophyllum trabeum, por um período de 12 semanas.
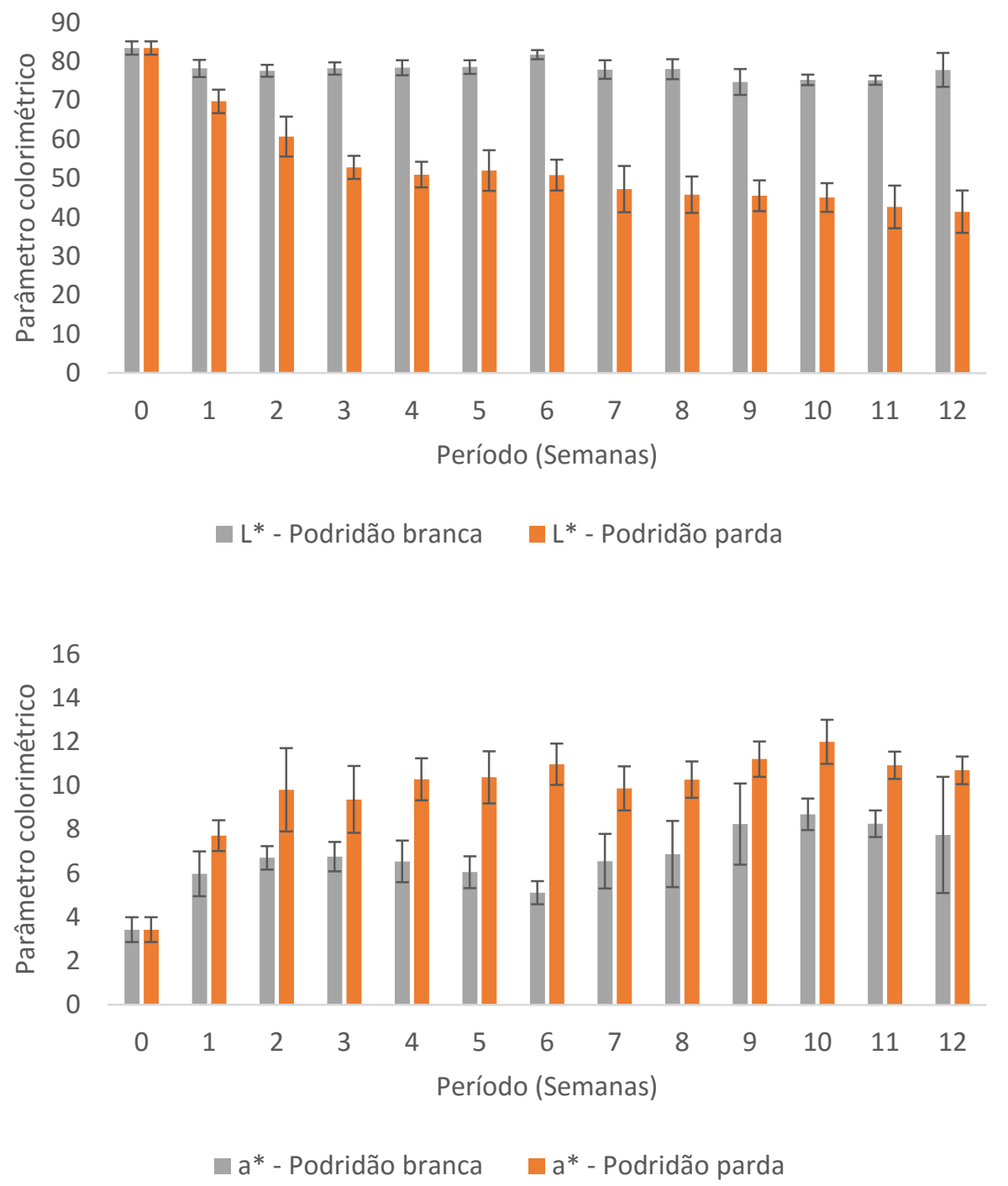

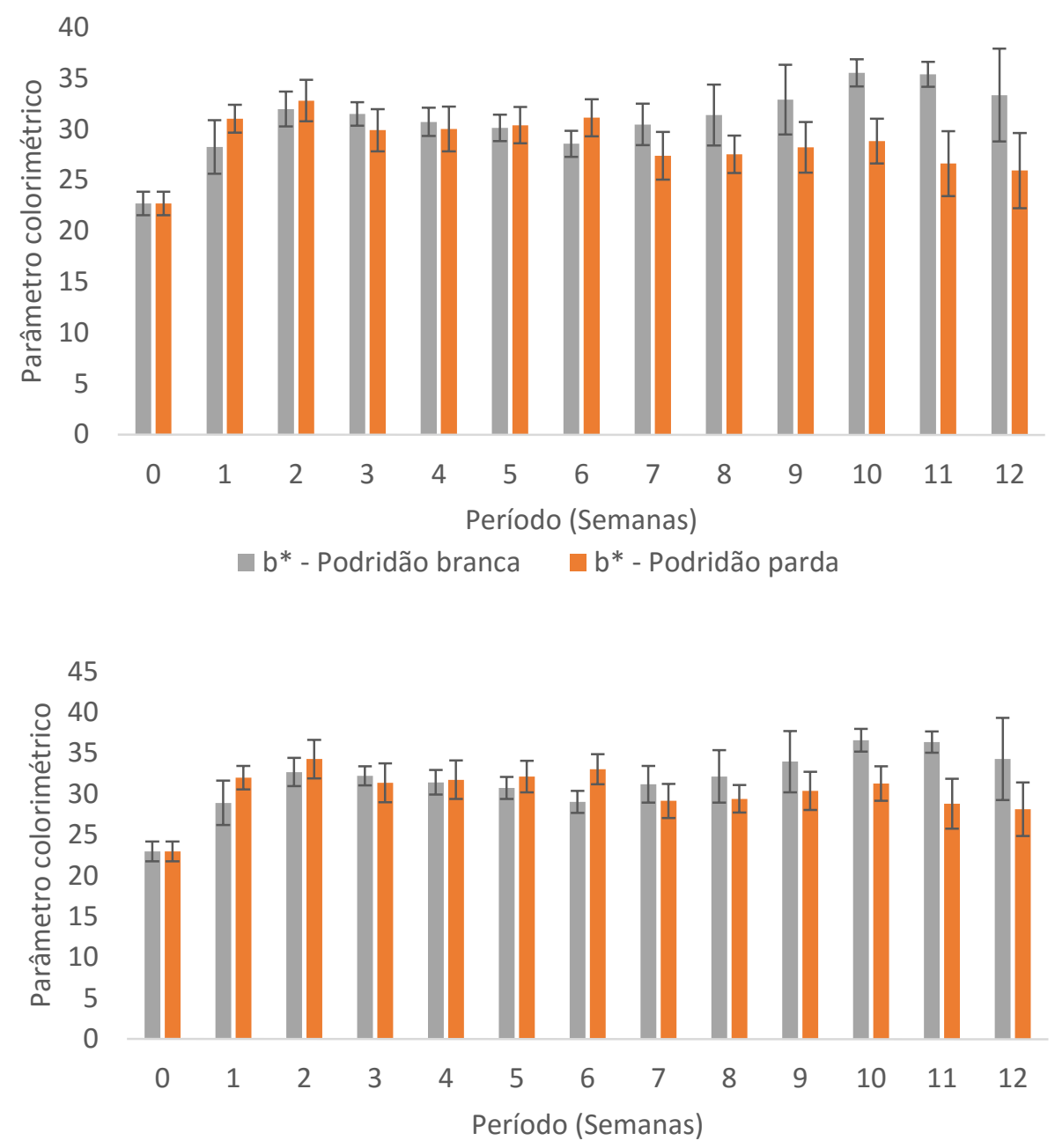

C C - Podridão branca $\square$ C - Podridão parda

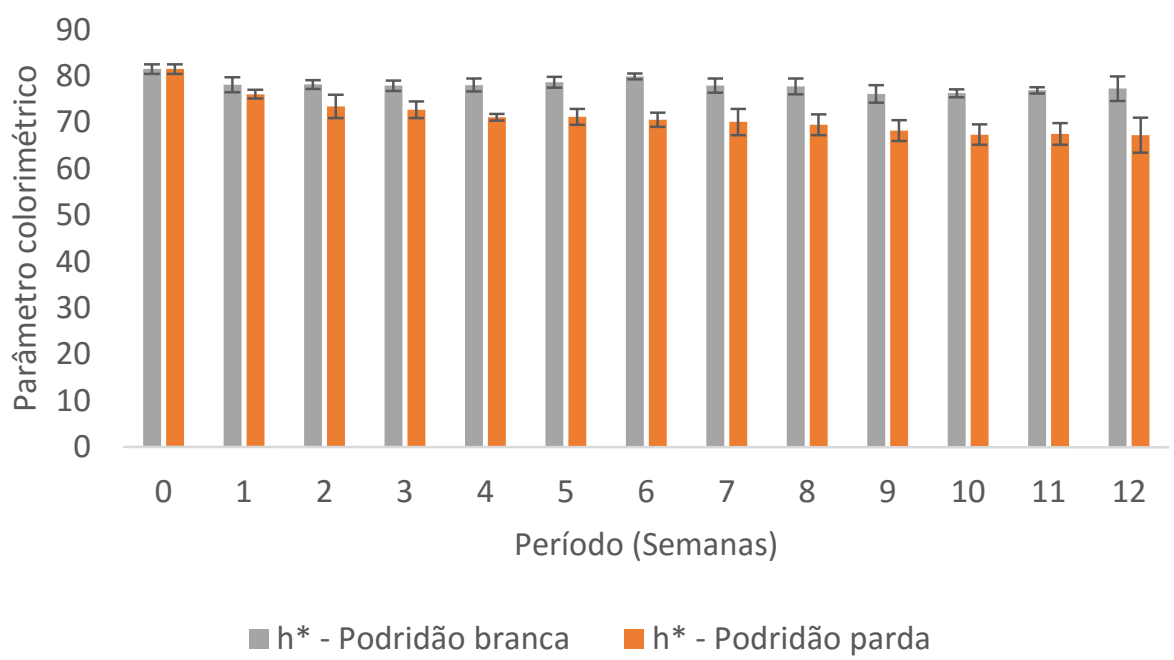

Figura 6.5 Alteração dos parâmetros colorimétricos da madeira de Simarouba amara após exposição aos fungos de podridão branca e parda, ao longo das 12 semanas. 


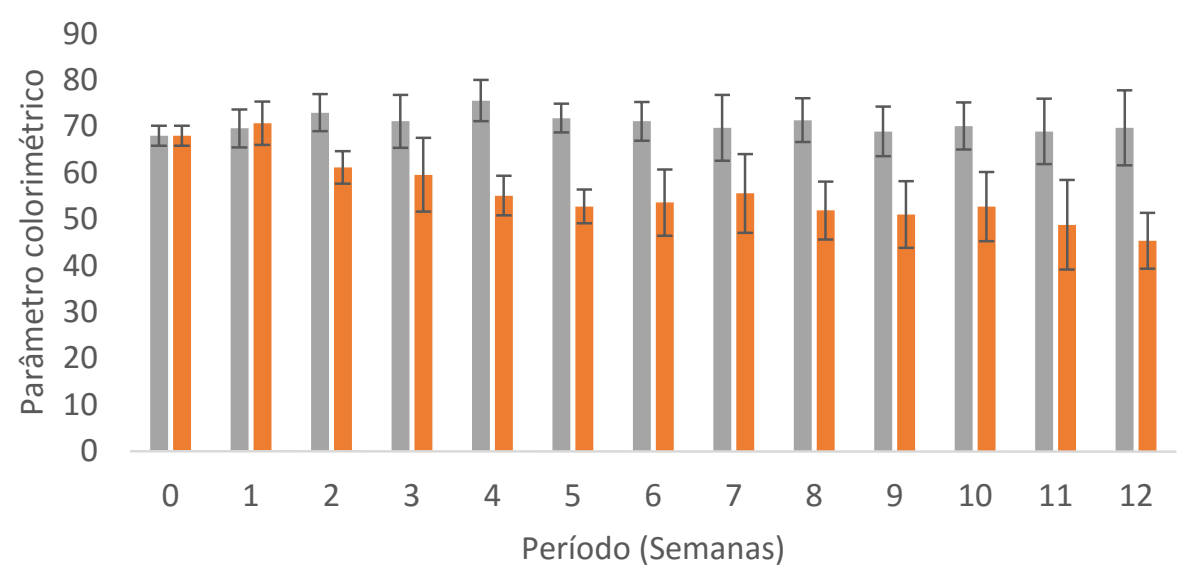

- L* - Podridão branca $\quad \mathrm{L}^{*}$ - Podridão parda

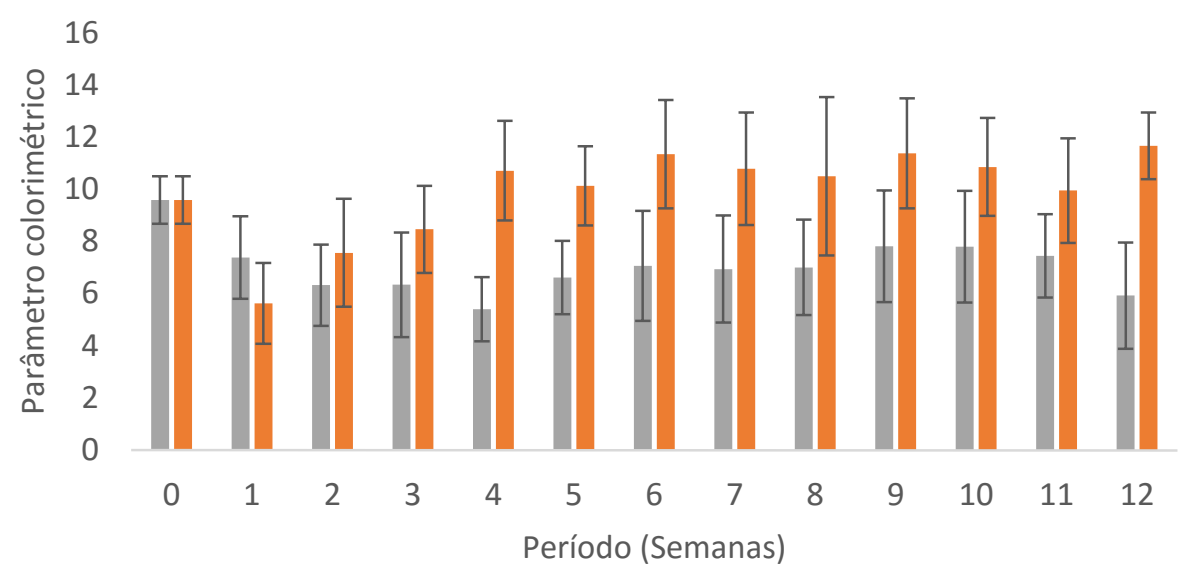

a* - Podridão branca $\square a^{*}$ - Podridão parda

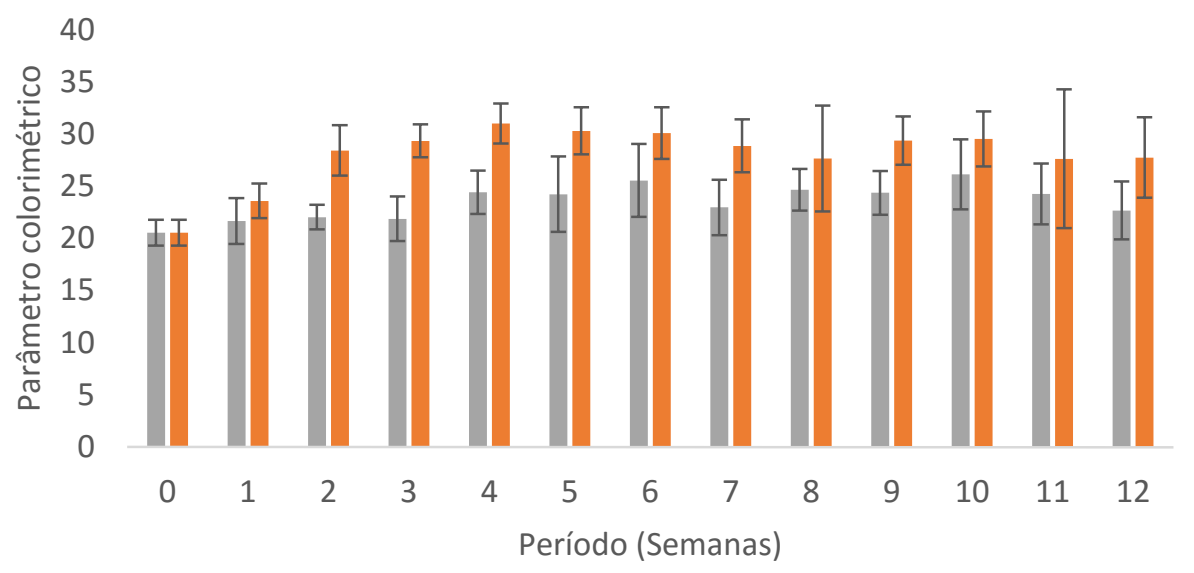

a* - Podridão branca $\square$ b* - Podridão parda 

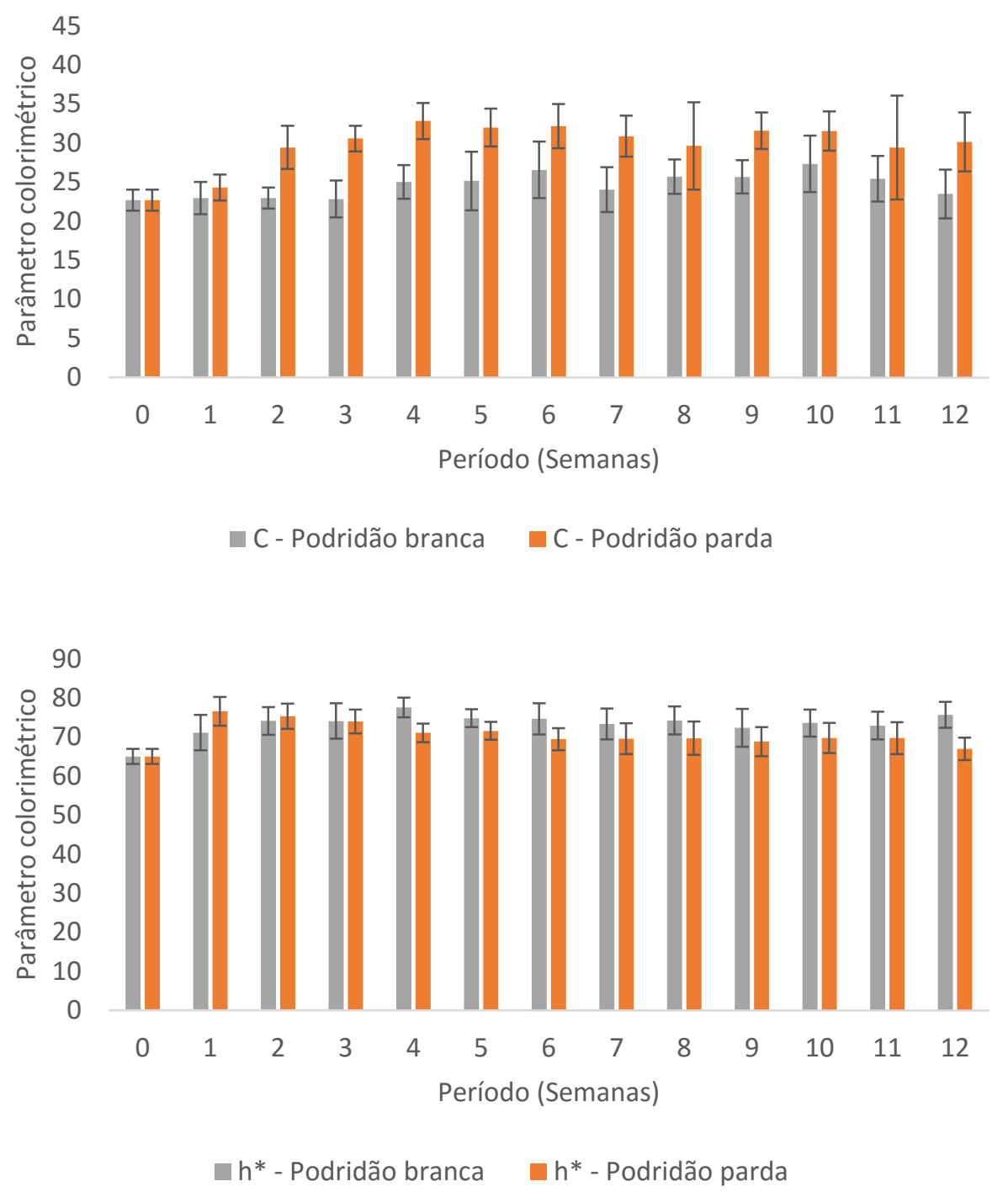

Figura 6.6 Alteração dos parâmetros colorimétricos da madeira de Eucalyptus saligna após exposição aos fungos de podridão branca e parda, ao longo das 12 semanas.

Por meio da análise do teste de médias (Apêndices B e C), verificou-se claramente a distinta ação dos fungos de podridão branca e podridão parda, em cada período do processo de biodeterioração das madeiras, uma vez que os fungos de podridão branca metabolizam indistintamente celulose, hemicelulose e lignina, enquanto que os de podridão parda deixam a lignina praticamente intacta.

Mais especificamente, para a madeira de Simarouba amara exposta ao fungo Trametes versicolor (podridão branca), ao longo das 12 semanas de ensaio houve uma redução do parâmetro $\mathrm{L}^{*}$ e um aumento dos parâmetros $\mathrm{a}^{*}$ e $\mathrm{b}^{*}$. Apesar do acréscimo na coordenada $a^{*}$, responsável pelo pigmento vermelho, o aumento verificado na coordenada $b^{*}$, responsável pelo pigmento amarelo, foi mais expressivo em termos numéricos. Como 
resultado, a cor da madeira de marupá tornou-se mais intensa e saturada, devido à interação entre os parâmetros $a^{*}$ e b*. Em função da leve redução da claridade $\left(L^{*}\right)$ da madeira, o ângulo de tinta $\left(\mathrm{h}^{*}\right)$ acompanhou esse comportamento, aproximando-se levemente do eixo verde-vermelho. Estes resultados estão de acordo com os observados por Costa (2009) e Stangerlin (2012) ao submeterem esta espécie de madeira ao fungo de podridão branca.

Ao ser exposta ao fungo Gloeophyllum trabeum (podridão parda), a madeira de Simarouba amara também apresentou uma redução do parâmetro L*, bem mais acentuada se comparada ao valor de $\mathrm{L}^{*}$ obtido após o ataque de podridão branca, indicando um intenso escurecimento da madeira. Isto se deve ao acréscimo expressivo na coordenada $a^{*}$, que provocou um avermelhamento na madeira. A coordenada $b^{*}$ sofreu um leve acréscimo, porém a variação na coordenada $a^{*}$ sobressaiu, sendo esta teoria confirmada pela redução significativa do ângulo de tinta (h*), que se aproximou do eixo verde-vermelho. A cor da madeira de marupá também se tornou mais intensa e saturada, condição comprovada pelo acréscimo no parâmetro $\mathrm{C}$ após o ataque de podridão parda. Os resultados obtidos para as alterações nos parâmetros L*, a* e h* corroboram os registros de Costa (2009) e Stangerlin (2012), ao avaliarem a madeira de marupá sob condições semelhantes.

Para a madeira de Eucalyptus saligna submetida ao ataque de Trametes versicolor (podridão branca), houve um leve acréscimo na claridade $\left(\mathrm{L}^{*}\right)$. Verificou-se também uma redução da coordenada $a^{*}$ e um aumento da coordenada $b^{*}$, indicando a maior influência deste parâmetro e o amarelecimento da madeira estudada, justificando o comportamento do parâmetro $L^{*}$ e o acréscimo na saturação $(C)$. O ângulo de tinta ( $\left.h^{*}\right)$ aumentou de maneira relevante após o ataque de podridão branca, confirmando o amarelecimento provocado pelo aumento da coordenada b*. Para o fungo Gloeophyllum trabeum, a luminosidade (L*) reduziu significativamente, ou seja, houve um escurecimento acentuado da madeira. Houve acréscimo nas coordenadas $a^{*}$ e $b^{*}$, sendo que a alteração no parâmetro $b^{*}$ seu deu mais expressivamente em termos numéricos. Entretanto, a madeira sadia de eucalipto já apresentava um aspecto avermelhado mais característico, o que fez com que o pigmento amarelo proporcionado pelo aumento na coordenada $b^{*}$ não se tornasse tão visível. Como o ângulo de tinta é influenciado pelas variações nos eixos verde-vermelho ( $\mathrm{a}^{*}$ ) e azul-amarelo $\left(b^{*}\right)$, sofreu um leve acréscimo provocado pelo aumento na coordenada $b^{*}$, que também justifica a maior saturação indicada pelo aumento no parâmetro C. A interação entres os parâmetros levou a uma coloração mais intensa e saturada na madeira de Eucalyptus saligna. 
As Tabelas 6.2 e 6.3 apresentam os valores da correlação de Pearson obtida entre as alterações dos parâmetros colorimétricos das madeiras de Simarouba amara e Eucalyptus saligna, e o período de ataque de podridão branca e parda.

Tabela 6.2 Correlação entre as alterações dos parâmetros colorimétricos da madeira de Simarouba amara e o período de ataque de podridão branca e parda.

\begin{tabular}{lcccccc}
\hline \multicolumn{7}{c}{ Trametes versicolor } \\
\hline Período (Semanas) & $\mathrm{L}^{*}$ & $\mathrm{a}^{*}$ & $\mathrm{~b}^{*}$ & $\mathrm{C}$ & $\mathrm{h}^{*}$ & $\Delta \mathrm{E}$ \\
\hline \multicolumn{7}{c}{ Gloeophyllum trabeum } \\
\hline $\mathrm{L}^{*}$ & $\mathrm{a}^{*}$ & $\mathrm{~b}^{*}$ & $\mathrm{C}$ & $\mathrm{h}^{*}$ & $\Delta \mathrm{E}$ \\
\hline Período (Semanas) & $-0,87^{* *}$ & $0,73^{* *}$ & $-0,25^{\mathrm{NS}}$ & $-0,06^{\mathrm{NS}}$ & $-0,91^{* *}$ & $0,85^{* *}$ \\
\hline
\end{tabular}

Em que: $\mathrm{L}^{*}=$ claridade; $\mathrm{a}^{*}=$ coordenada verde-vermelho; $\mathrm{b}^{*}=$ coordenada azul-amarelo; $\mathrm{C}=$ saturação da cor; $\mathrm{h}^{*}=$ ângulo de tinta; $\Delta \mathrm{E}=$ variação total da cor; **= significativo a $1 \%$; $=$ significativo a $5 \% ;{ }^{\mathrm{NS}}=$ não significativo.

Tabela 6.3 Correlação entre as alterações dos parâmetros colorimétricos da madeira de Eucalyptus saligna e o período de ataque de podridão branca e parda.

\begin{tabular}{|c|c|c|c|c|c|c|}
\hline \multicolumn{7}{|c|}{ Trametes versicolor } \\
\hline & $\mathrm{L}^{*}$ & $\mathrm{a}^{*}$ & $b^{*}$ & $\mathrm{C}$ & $\mathrm{h}^{*}$ & $\Delta \mathrm{E}$ \\
\hline Período (Semanas) & $-0,23^{\mathrm{NS}}$ & $-0,16^{\mathrm{NS}}$ & $0,63 *$ & $0,60 *$ & $0,42^{\mathrm{NS}}$ & $0,24^{\mathrm{NS}}$ \\
\hline \multicolumn{7}{|c|}{ Gloeophyllum trabeum } \\
\hline & $\mathrm{L}^{*}$ & $\mathrm{a}^{*}$ & $b^{*}$ & $\mathrm{C}$ & $\mathrm{h}^{*}$ & $\Delta \mathrm{E}$ \\
\hline Período (Semanas) & $-0,91 * *$ & $0,69 * *$ & $0,44^{\mathrm{NS}}$ & $0,53^{\mathrm{NS}}$ & $-0,44^{\mathrm{NS}}$ & $0,88 * *$ \\
\hline
\end{tabular}

Em que: $\mathrm{L}^{*}=$ claridade; $\mathrm{a}^{*}=$ coordenada verde-vermelho; $\mathrm{b}^{*}=$ coordenada azul-amarelo; $\mathrm{C}=$ saturação da cor; $\mathrm{h}^{*}=$ ângulo de tinta; $\Delta \mathrm{E}=$ variação total da cor; $* *=$ significativo a $1 \% ; *=$ significativo a $5 \% ;{ }^{\mathrm{NS}}=$ não significativo.

A partir da análise das tabelas de correlações, pode-se observar que, para ambas as espécies de madeira e ambos os fungos, o parâmetro $L^{*}$ apresentou correlação negativa e significativa, indicando um escurecimento da madeira, exceto para Eucalyptus saligna ao ser exposta ao fungo de podridão branca. $\mathrm{O}$ escurecimento mostrou-se mais acentuado e significativo após as madeiras serem submetidas ao fungo de podridão parda.

Para a madeira de Simarouba amara atacada por Trametes versicolor, os parâmetros a*, b* e C apresentaram correlações positivas e significativas, destacando a intensificação e saturação da cor ao longo do período de exposição, o que também é confirmado pela correlação negativa do ângulo de tinta $\left(\mathrm{h}^{*}\right)$. Após o ataque de Gloeophyllum trabeum à essa 
espécie de madeira, apenas os parâmetros $\mathrm{L}^{*}, \mathrm{a}^{*} \mathrm{e} \mathrm{h}^{*}$ mostraram estar significativamente correlacionados com o período de exposição ao fungo, destacando o escurecimento acentuado observado na madeira. Resultados semelhantes foram obtidos por Stangerlin (2012) ao submeter a madeira de marupá aos fungos de podridão branca e parda.

Para a madeira de Eucalyptus saligna, após ser submetida ao ataque de Trametes versicolor, verificou-se que apenas os parâmetros $b^{*}$ e C apresentaram correlação significativa e positiva em relação ao tempo de duração do ensaio, destacando a alteração na pigmentação amarelada. Ao ser atacada por Gloeophyllum trabeum, os parâmetros L* e a* mostraram correlação significativa com o período de exposição ao fungo e, ao contrário da observação obtida após o ataque de podridão branca, enfatizando a influência da coordenada $a^{*}$, responsável pela pigmentação avermelhada.

A variação total da cor $(\Delta \mathrm{E})$ apresentou correlação positiva e significativa com o período de exposição das madeiras aos fungos apodrecedores, exceto para a madeira de eucalipto submetida à podridão branca.

As Figuras 6.7 e 6.8 apresentam as curvas de reflectância das madeiras de Simarouba amara (marupá) e Eucalyptus saligna (eucalipto), antes e após 12 semanas de exposição aos fungos de podridão branca e parda. $\mathrm{O}$ apêndice $\mathrm{D}$ apresenta o aspecto visual das amostras.

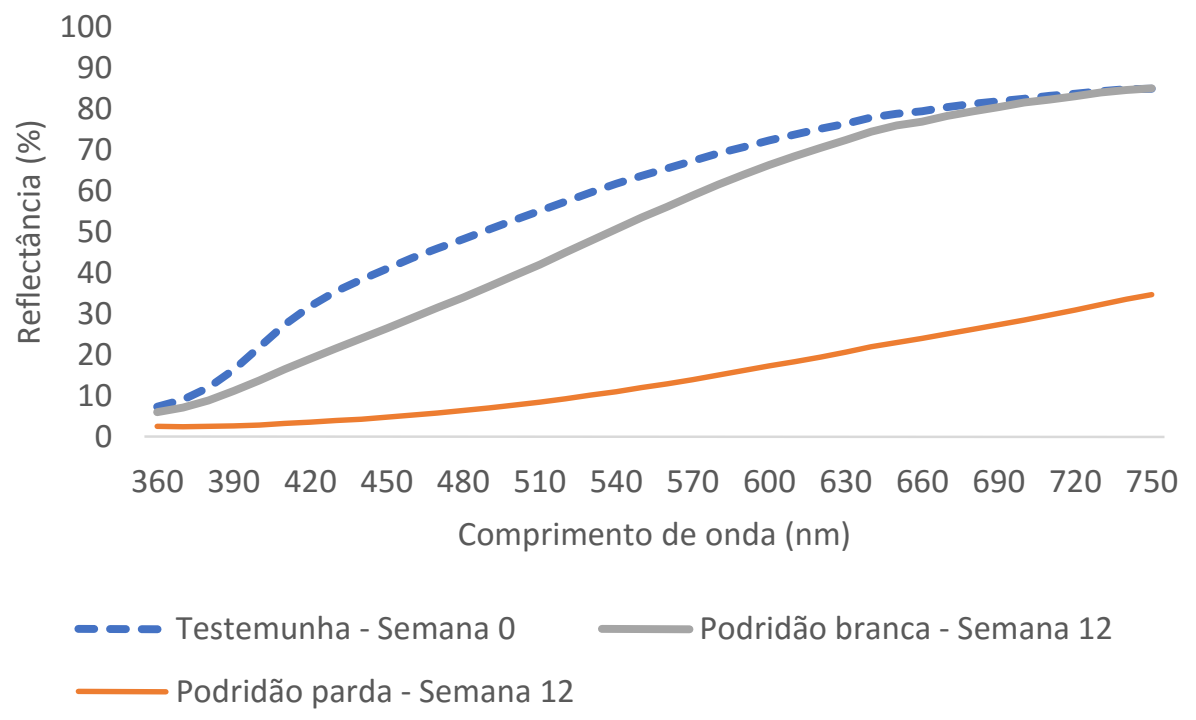

Figura 6.7 Curva de reflectância da madeira de Simarouba amara antes e após o ataque de podridão branca e parda. 


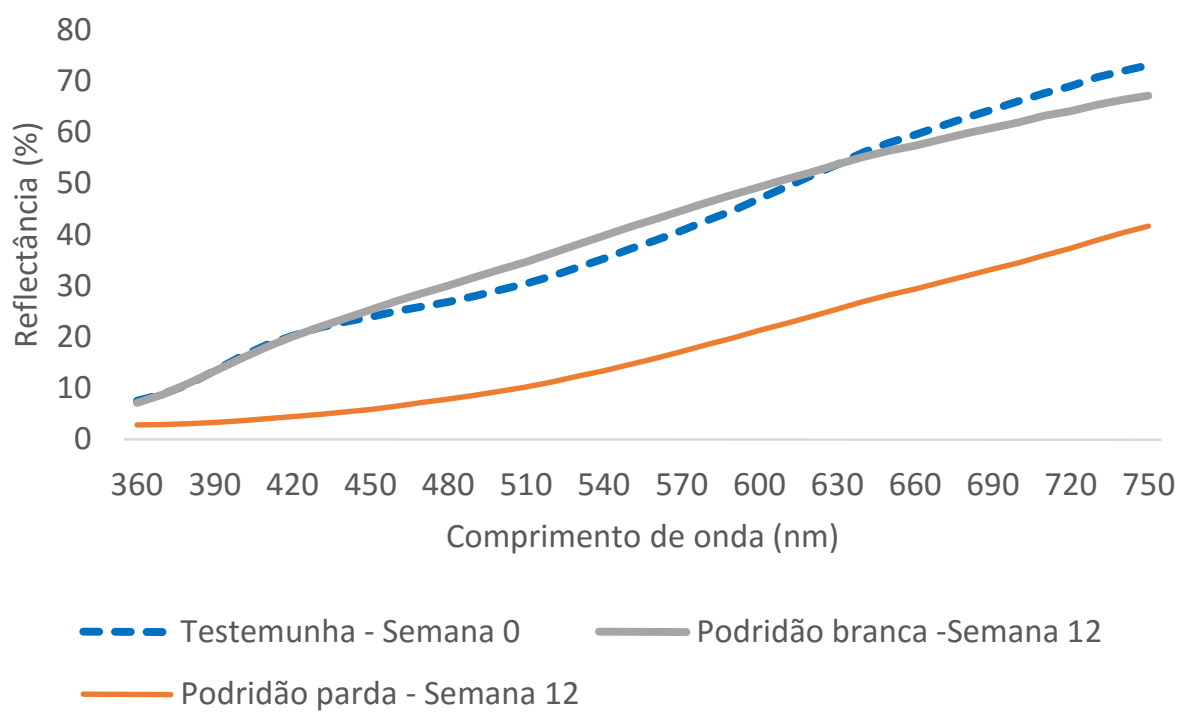

Figura 6.8 Curva de reflectância da madeira de Eucalyptus saligna antes e após o ataque de podridão branca e parda.

Verificou-se a partir da análise das curvas de reflectância que a madeira de marupá apresentou uma menor reflectância da luz após o ataque de ambos os fungos, enquanto que a madeira de eucalipto passou a refletir mais a luz incidente após o ataque de podridão branca e menos após ser exposta ao fungo de podridão parda.

As Tabelas 6.4 e 6.5 apresentam os valores da variação total da cor $(\Delta \mathrm{E})$ e sua classificação, proposta por Stangerlin (2012).

Tabela 6.4 Variação total da cor $(\Delta \mathrm{E})$ das madeiras de Simarouba amara e Eucalyptus saligna após exposição ao fungo Trametes versicolor.

\begin{tabular}{ccccc}
\hline PERÍODO DE & \multicolumn{3}{c}{ Simarouba amara } & \multicolumn{2}{c}{ Eucalyptus saligna } \\
\cline { 2 - 5 } ATAQUE & & & & \\
Trametes versicolor & $\Delta \mathrm{E}$ & Classificação & $\Delta \mathrm{E}$ & Classificação \\
\hline 1 & 8,03 & Muito perceptível & 2,93 & Ligeiramente perceptível \\
2 & 11,43 & Muito perceptível & 6,13 & Perceptível \\
3 & 10,76 & Muito perceptível & 4,68 & Perceptível \\
4 & 9,97 & Muito perceptível & 9,49 & Muito perceptível \\
5 & 9,23 & Muito perceptível & 6,06 & Perceptível \\
6 & 6,32 & Perceptível & 6,41 & Perceptível \\
7 & 10,02 & Muito perceptível & 3,97 & Ligeiramente perceptível \\
8 & 10,79 & Muito perceptível & 5,90 & Perceptível \\
9 & 14,26 & Muito perceptível & 4,30 & Perceptível \\
10 & 16,08 & Muito perceptível & 6,24 & Perceptível \\
11 & 15,87 & Muito perceptível & 4,37 & Perceptível \\
12 & 14,79 & Muito perceptível & 4,57 & Perceptível \\
\hline
\end{tabular}


Tabela 6.5 Variação total da cor $(\Delta \mathrm{E})$ das madeiras de Simarouba amara e Eucalyptus saligna após exposição ao fungo Gloeophyllum trabeum.

\begin{tabular}{ccccc}
\hline PERÍODO DE & \multicolumn{2}{c}{ Simarouba amara } & \multicolumn{2}{c}{ Eucalyptus saligna } \\
\cline { 2 - 5 } ATAQUE & & & & \\
Gloeophyllum trabeum & $\Delta \mathrm{E}$ & Classificação & $\Delta \mathrm{E}$ & Classificação \\
\hline 1 & 16,57 & Muito perceptível & 5,69 & Perceptível \\
2 & 25,68 & Muito perceptível & 10,62 & Muito perceptível \\
3 & 32,00 & Muito perceptível & 12,23 & Muito perceptível \\
4 & 34,02 & Muito perceptível & 16,64 & Muito perceptível \\
5 & 33,13 & Muito perceptível & 18,11 & Muito perceptível \\
6 & 34,54 & Muito perceptível & 17,37 & Muito perceptível \\
7 & 37,10 & Muito perceptível & 15,00 & Muito perceptível \\
8 & 38,58 & Muito perceptível & 17,63 & Muito perceptível \\
9 & 39,11 & Muito perceptível & 19,23 & Muito perceptível \\
10 & 39,80 & Muito perceptível & 17,76 & Muito perceptível \\
11 & 41,63 & Muito perceptível & 20,47 & Muito perceptível \\
12 & 42,77 & Muito perceptível & 23,85 & Muito perceptível \\
\hline
\end{tabular}

Verificou-se que, para a madeira de Simarouba amara, após 12 semanas de exposição aos fungos apodrecedores, a variação total da cor ocorreu em maior magnitude e foi classificada como muito perceptível. A variação total da cor na madeira de Eucalyptus saligna foi classificada como perceptível e muito perceptível, após 12 semanas de exposição aos fungos Trametes versicolor e Gloeophyllum trabeum, respectivamente. Partindo-se da hipótese de que quanto maior a resistência natural da madeira, menor será a variação total da cor após o ataque de fungos apodrecedores, pode-se inferir que a madeira de Eucalyptus saligna possui uma maior resistência natural à biodeterioração pelo fungo apodrecedor Trametes versicolor. Além disso, é importante ressaltar a clara diferença na magnitude dos valores registrados para Simarouba amara e Eucalyptus saligna, uma vez que esta, em função de sua maior resistência à biodeterioração, apresentou valores de variação total da cor bem inferiores aos obtidos para a madeira de Simarouba amara.

Altos valores de variação da cor $(\Delta \mathrm{E})$ foram verificados por Okino et al. (2015) após submeterem amostras de Couratari oblongifolia, Couratari guianensis e Couratari stellata a Gloephyllum trabeum, enquanto que uma menor variação da cor foi observada após o ataque de Trametes versicolor. Os autores atribuíram às variações nos parâmetros $\mathrm{L}^{*} \mathrm{e} \mathrm{b}^{*}$ das madeiras atacadas por fungo de podridão parda e branca, respectivamente. Tais resultados são semelhantes aos encontrados neste estudo. 
O tempo é um fator classificado como quantitativo, portanto, houve a necessidade de realizar análise de regressão para avaliar a sua influência sobre as alterações nos parâmetros colorimétricos após o período de exposição das madeiras aos fungos apodrecedores. Os modelos de predição gerados pela regressão, para os casos de correlação significativa, estão apresentados nas Figuras 6.9 e 6.10.
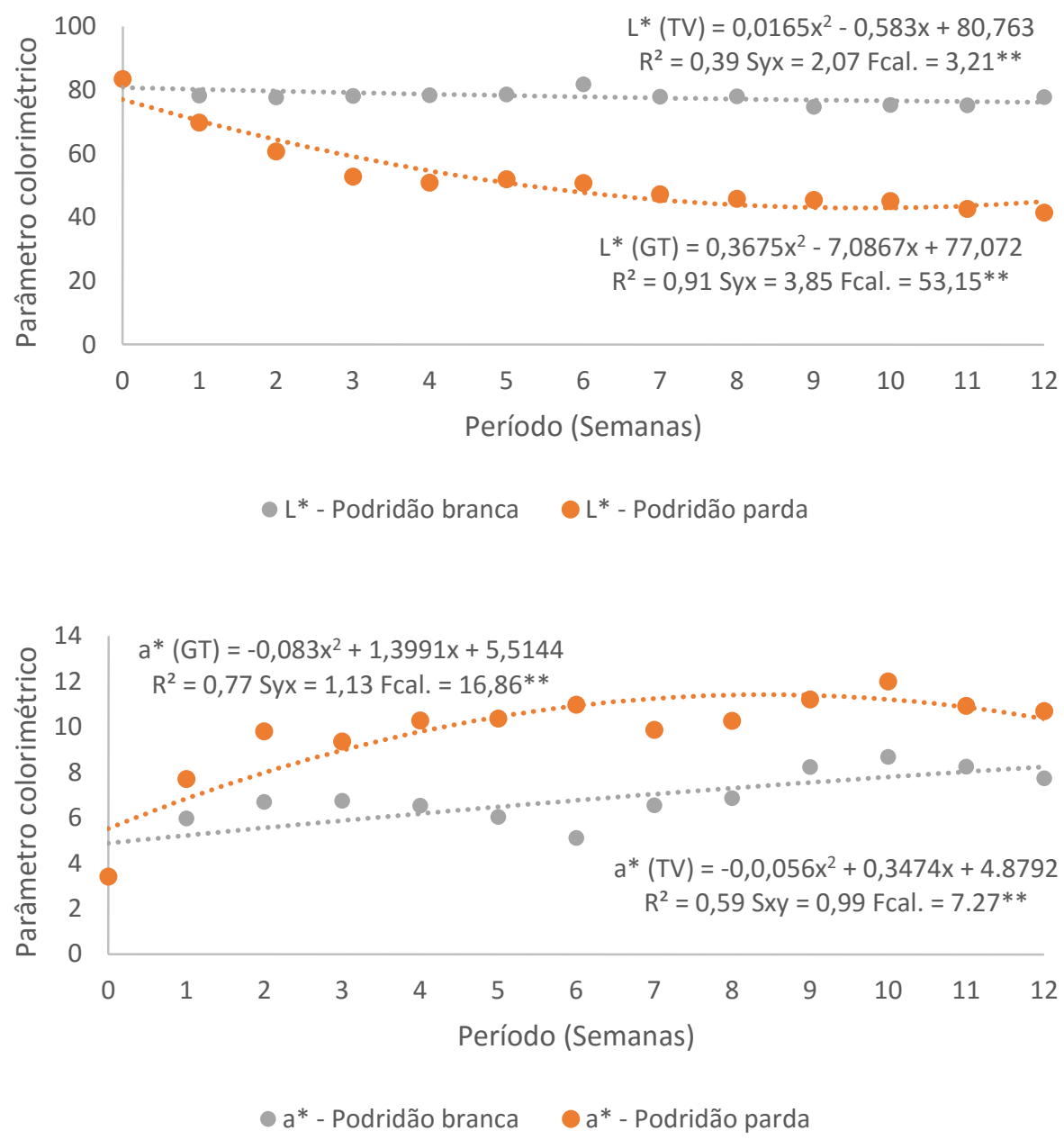

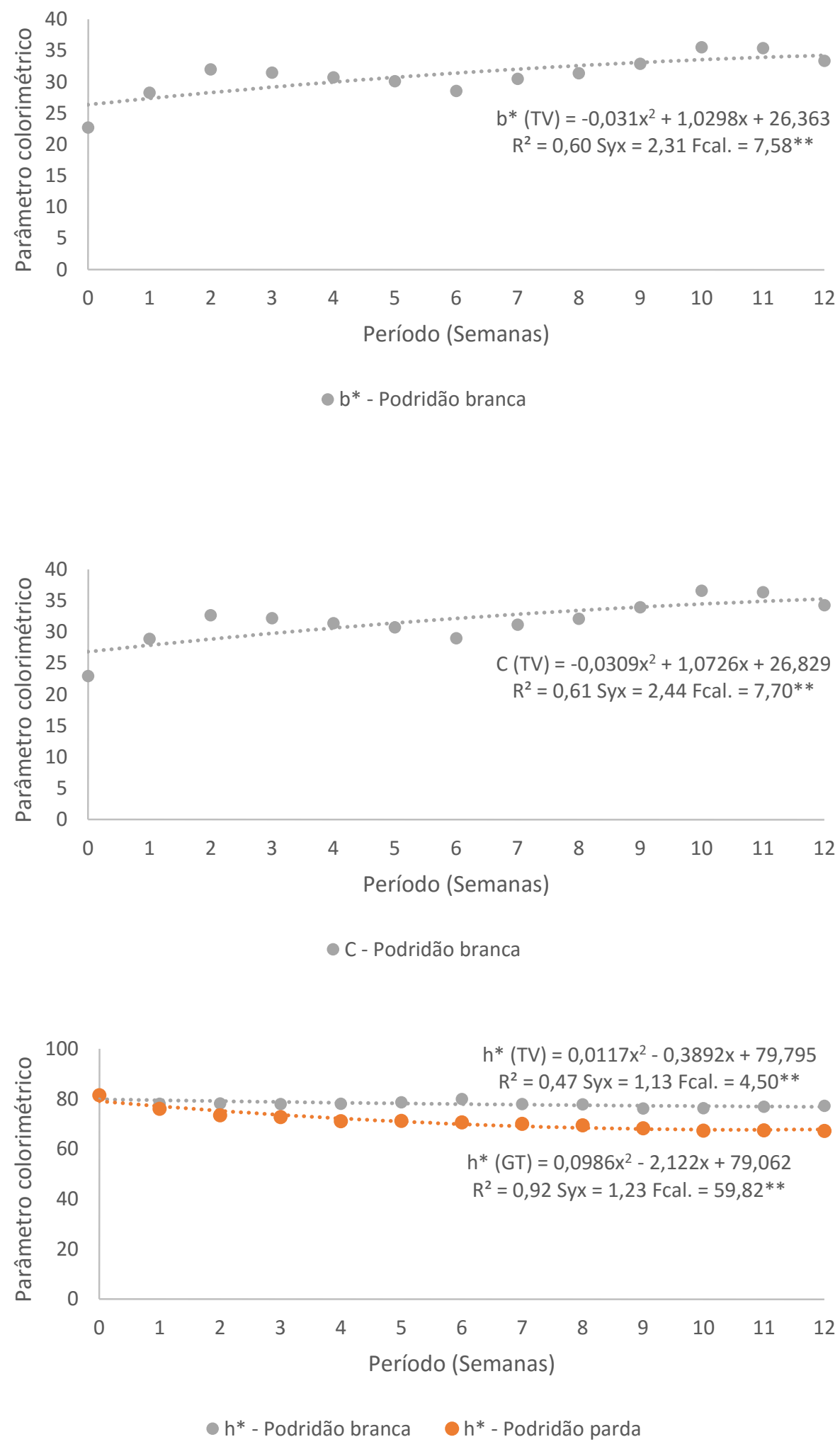

Figura 6.9 Modelos estatísticos gerados para predição das alterações dos parâmetros colorimétricos L*, a*, b*, C e h* da madeira de Simarouba amara, em função do tempo de exposição aos fungos Trametes versicolor (TV) e Gloeophyllum trabeum (GT). 

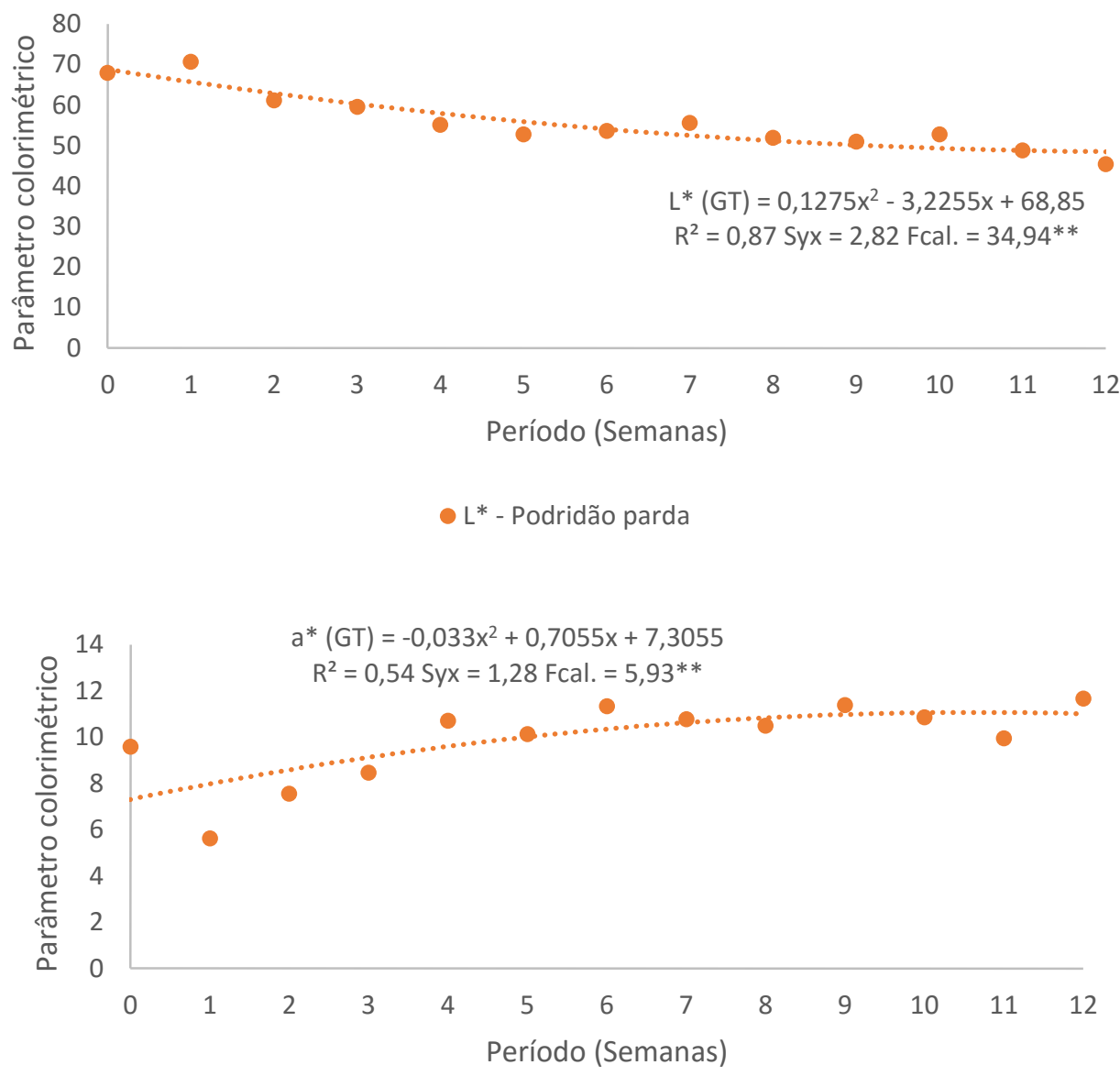

a* - Podridão parda

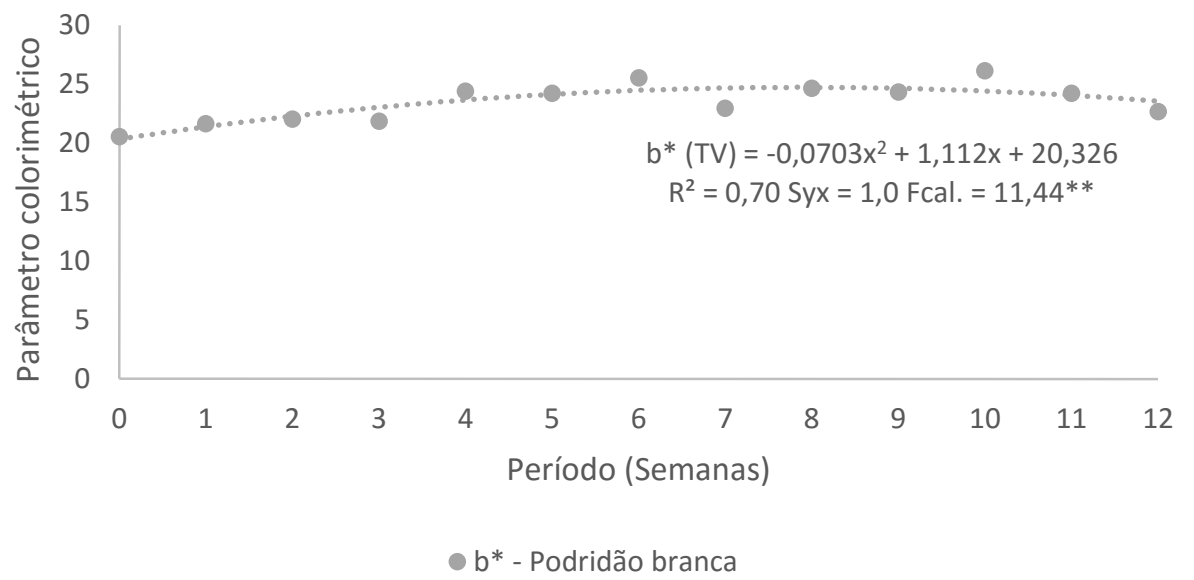




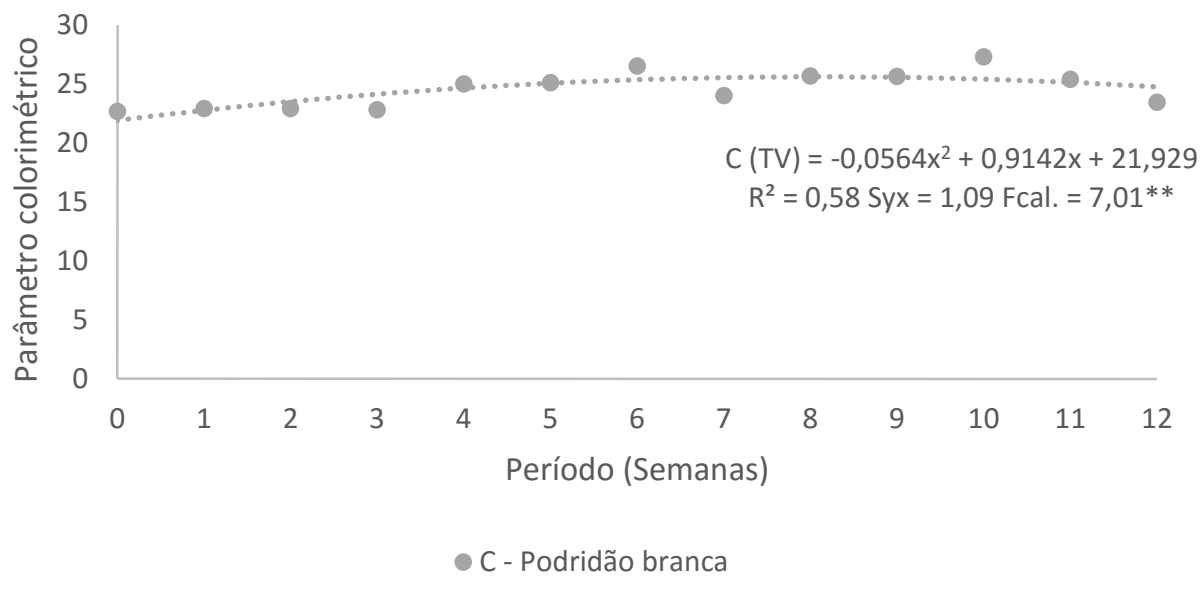

Figura 6.10 Modelos estatísticos gerados para predição das alterações dos parâmetros colorimétricos L*, a*, b*, C e h* da madeira de Eucalyptus saligna, em função do tempo de exposição aos fungos Trametes versicolor (TV) e Gloeophyllum trabeum (GT).

Considerando os parâmetros estatísticos $\mathrm{R}^{2}$, Syx e $\mathrm{F}$ calculado, os modelos polinomiais gerados conseguiram explicar uma variabilidade expressiva dos parâmetros colorimétricos em função do tempo de exposição aos fungos, além de todos os ajustes serem significativos a 5\%, implicando na relevância do fator tempo sobre as alterações nos parâmetros colorimétricos.

As Tabelas 6.6 e 6.7 apresentam os valores da correlação de Pearson obtida entre as alterações dos parâmetros colorimétricos das madeiras de Simarouba amara e Eucalyptus saligna e perda de massa ocorrida durante as 12 semanas de ensaio.

Tabela 6.6 Correlação entre as alterações dos parâmetros colorimétricos da madeira de Simarouba amara e a perda de massa após ataque de podridão branca e parda.

\begin{tabular}{ccccccc}
\hline \multicolumn{7}{c}{ Simarouba amara } \\
\hline & $\mathrm{L}^{*}$ & $\mathrm{a}^{*}$ & $\mathrm{~b}^{*}$ & $\mathrm{C}$ & $\mathrm{h}^{*}$ & $\Delta \mathrm{E}$ \\
\hline PM - TV (\%) & $-0,61^{*}$ & $0,75^{* *}$ & $0,76^{* *}$ & $0,76^{* *}$ & $-0,66^{*}$ & $0,73^{* *}$ \\
PM - GT (\%) & $-0,91^{* *}$ & $0,76^{* *}$ & $-0,21^{\mathrm{NS}}$ & $-0,02^{\mathrm{NS}}$ & $-0,93^{* *}$ & $0,89^{* *}$
\end{tabular}

Em que: $\mathrm{L}^{*}=$ claridade; $\mathrm{a}^{*}=$ coordenada verde-vermelho; $\mathrm{b}^{*}=$ coordenada azul-amarelo; $\mathrm{C}=$ saturação da cor; $\mathrm{h}^{*}=$ ângulo de tinta; $\Delta \mathrm{E}=$ variação total da cor; $\mathrm{PM}-\mathrm{TV}=$ perda de massa após ataque de Trametes versicolor; PM-GT= perda de massa após ataque de Gloeophyllum trabeum $; * *=$ significativo a $1 \% ; *=$ significativo a $5 \% ;{ }^{N S}=$ não significativo. 
Tabela 6.7 Correlação entre as alterações dos parâmetros colorimétricos da madeira de Eucalyptus saligna e a perda de massa após ataque de podridão branca e parda.

\begin{tabular}{ccccccc}
\hline \multicolumn{7}{c}{ Eucalyptus saligna } \\
\hline & $\mathrm{L}^{*}$ & $\mathrm{a}^{*}$ & $\mathrm{~b}^{*}$ & $\mathrm{C}$ & $\mathrm{h}^{*}$ & $\Delta \mathrm{E}$ \\
\hline PM - TV (\%) & $-0,20^{\mathrm{NS}}$ & $-0,18^{\mathrm{NS}}$ & $0,57^{*}$ & $0,54^{\mathrm{NS}}$ & $0,41^{\mathrm{NS}}$ & $0,24^{\mathrm{NS}}$ \\
$\mathrm{PM}-\mathrm{GT}(\%)$ & $-0,92^{* *}$ & $0,74^{* *}$ & $0,44^{\mathrm{NS}}$ & $0,54^{\mathrm{NS}}$ & $-0,49^{\mathrm{NS}}$ & $0,88^{* *}$
\end{tabular}

Em que: $\mathrm{L}^{*}=$ claridade; $\mathrm{a}^{*}=$ coordenada verde-vermelho; $\mathrm{b}^{*}=$ coordenada azul-amarelo; $\mathrm{C}=$ saturação da cor; $\mathrm{h}^{*}=$ ângulo de tinta; $\Delta \mathrm{E}=$ variação total da cor; $\mathrm{PM}-\mathrm{TV}=$ perda de massa após ataque de Trametes versicolor; PM-GT= perda de massa após ataque de Gloeophyllum trabeum $; *$ * = significativo a $1 \% ; *=$ significativo a $5 \% ;{ }^{\mathrm{NS}}=$ não significativo.

A partir da análise das correlações obtidas para a madeira de Simarouba amara, verificouse que todos os parâmetros apresentaram-se correlacionados de maneira significativa com a perda de massa sofrida após o ataque de Trametes versicolor, mostrando o mecanismo enzimático deste fungo, que ataca os polissacarídeos indistintamente. Após o ataque de Gloeophyllum trabeum, apenas os parâmetros $\mathrm{L}^{*}, \mathrm{a}^{*} \mathrm{e} \mathrm{h}^{*}$ mostraram estar correlacionados significativamente com a perda de massa da madeira, indicando o escurecimento provocado pela ação enzimática deste fungo.

Para os dados obtidos a partir da madeira de Eucalyptus saligna, após a exposição ao fungo de podridão branca, apenas a coordenada $b^{*}$ apresentou correlação com a perda de massa, $o$ que justifica o amarelecimento da madeira. Em contradição àquela, apenas os parâmetros $\mathrm{L}^{*}$ e a* apresentaram correlação significativa com a perda de massa, após o ataque de Gloeophyllum trabeum, o que também pode ser explicado pelo mecanismo enzimático do fungo de podridão parda.

Houve correlação positiva e significativa entre a variação total da cor $(\Delta \mathrm{E})$ e a perda de massa provocada pelo ataque dos fungos apodrecedores às madeiras, exceto para a madeira de eucalipto submetida à podridão branca.

Ao avaliarem as respostas colorimétricas na madeira de Tectona grandis ao fungo de podridão branca $C$. versicolor, Kokutse et al. (2006) verificaram uma correlação alta e significativa entre a luminosidade $\left(\mathrm{L}^{*}\right)$ e a porcentagem de perda de massa. Além disso, ao considerarem os parâmetros $\mathrm{L}^{*}, \mathrm{a}^{*}$ e b* em conjunto, até $76 \%$ da variabilidade na perda de massa pôde ser explicada. Entretanto, não observaram correlações significativas entre o parâmetro $b^{*}$ e a perda de massa decorrente do ataque do fungo de podridão parda Gloeophyllum trabeum, legitimando os dados das Tabelas 6.6 e 6.7. 
Okino et al. (2015) também verificaram correlações significativas entre a perda de massa e os parâmetros a* e $\Delta \mathrm{E}$ após expor as madeiras de Couratari oblongifolia, Couratari guianensis e Couratari stellata a vários fungos apodrecedores, dentre eles Trametes versicolor e Gloeophyllum trabeum, corroborando os resultados encontrados no presente estudo.

Almeida et al. (2012), ao avaliarem a madeira de cedro australiano após exposição aos fungos apodrecedores Trametes versicolor e Gloeophyllum trabeum, verificaram a sensibilidade das variáveis colorimétricas em relação à perda de massa.

Stangerlin (2012) observou que os parâmetros L*, a* e b* auxiliaram como indicadores de perda de massa para a madeira de marupá e jequitibá após período de ataque de Trametes versicolor e Gloeophyllum trabeum. Alterações nestes mesmos parâmetros foram verificadas por Kokutse et al. (2006) ao estudar a madeira de Tectona grandis atacada por Trametes versicolor.

A variação da cor da madeira vêm sendo relacionada com as propriedades de resistência ao ataque de organismos xilófagos, como os fungos apodrecedores. Segundo Oliveira et al. (2005), a durabilidade natural das madeiras é conferida pelos seus componentes secundários (extrativos), que na maioria das vezes se apresentam em pequenas proporções, mas podem, em algumas espécies, atingir valores bastante elevados. Okino et al. (2015) também destacaram que geralmente há correlação inversa entre o conteúdo de extrativos e a perda de massa.

Moya et al. (2012) observaram diferença significativa entre os parâmetros colorimétricos de cerne e alburno em função dos extrativos presentes. Para Hittler et al. (1972), o alto teor de extrativos está relacionado com a claridade $\left(\mathrm{L}^{*}\right)$, ou seja, quanto maior a quantidade de substâncias extratáveis coloridas depositadas nas paredes celulares da madeira, mais escura ela é. Partindo do pressuposto de que a resistência natural está ligada ao parâmetro L*, podese inferir que também está diretamente relacionada às alterações nas coordenadas $\mathrm{a}^{*}$ (eixo verde-vermelho) e b* (eixo azul-amarelo).

\subsection{ANÁLISE QUÍMICA}

\subsubsection{Espectroscopia no infravermelho médio (MIR)}


Os espectros no infravermelho médio, obtidos com auxílio do acessório DRIFT, das madeiras sadias de Simarouba amara e Eucalyptus saligna estão apresentados na Figura 6.11 .

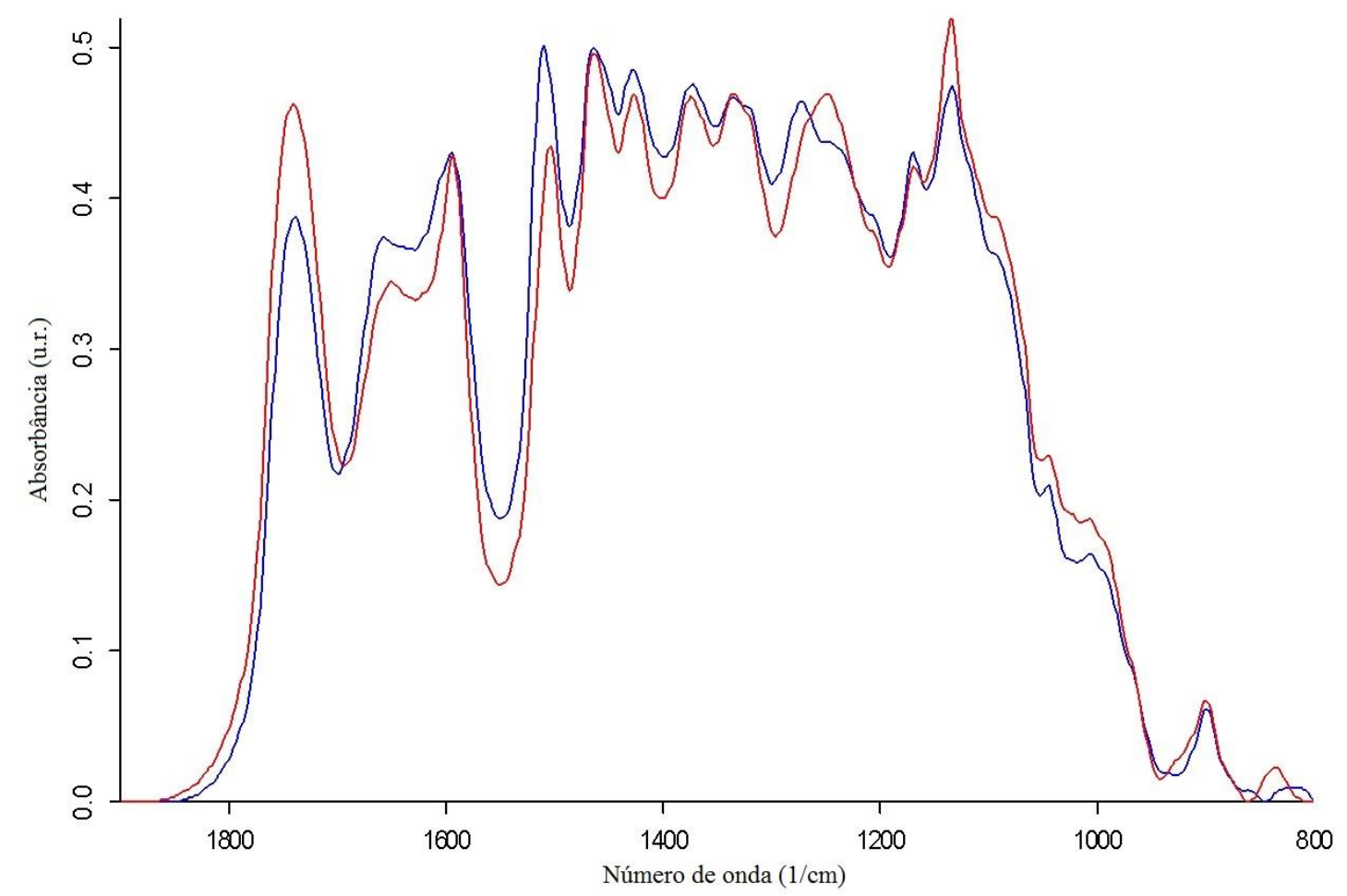

Figura 6.11 Espectros no infravermelho médio das madeiras sadias de Simarouba amara (azul) e Eucalyptus saligna (vermelho).

Assim como os gráficos de emissão de fluorescência, os espectros de infravermelho são bastante semelhantes entre si, com as mesmas bandas, variando apenas a intensidade ou localização das bandas. Isto ocorre devido à composição química da madeira, que é um biopolímero tridimensional formado por compostos de alto peso molecular como celulose, hemiceluloses, ligninas e, em menor quantidade, por compostos de baixo peso molecular, como os extrativos.

As bandas a serem analisadas foram definidas dentro do intervalo de 1900 a $800 \mathrm{~cm}^{-1}$, em função da maior concentração de bandas relacionadas aos compostos químicos da madeira, e estão ilustradas nas Figuras 6.12 e 6.13. Em função da natureza biológica do material e das análises serem semi-quantitativas, variações referentes às posições e intensidades das bandas ocorrem, e algumas distinções são observadas em relação aos dados obtidos na literatura. Pandey (1999) relata que somente as bandas em torno de $3400 \mathrm{~cm}^{-1}(\mathrm{O}-\mathrm{H}), 2900 \mathrm{~cm}^{-1}(\mathrm{C}-\mathrm{H})$, 
$1740 \mathrm{~cm}^{-1}(\mathrm{C}=\mathrm{O})$ e $1510 \mathrm{~cm}^{-1}(\mathrm{C}=\mathrm{C})$ podem ser consideradas puras. Isto implica que as outras bandas são formadas a partir da sobreposição das bandas de lignina, celulose, polioses e extrativos, dificultando assim, a atribuição química dessas bandas (TOLJAV; FAIX, 1995; PASTORE, 2004; FERRAZ et al., 2000; STANGERLIN, 2012). Entretanto, a atribuição de bandas a componentes isolados em espectros de infravermelho ainda não é consenso geral.

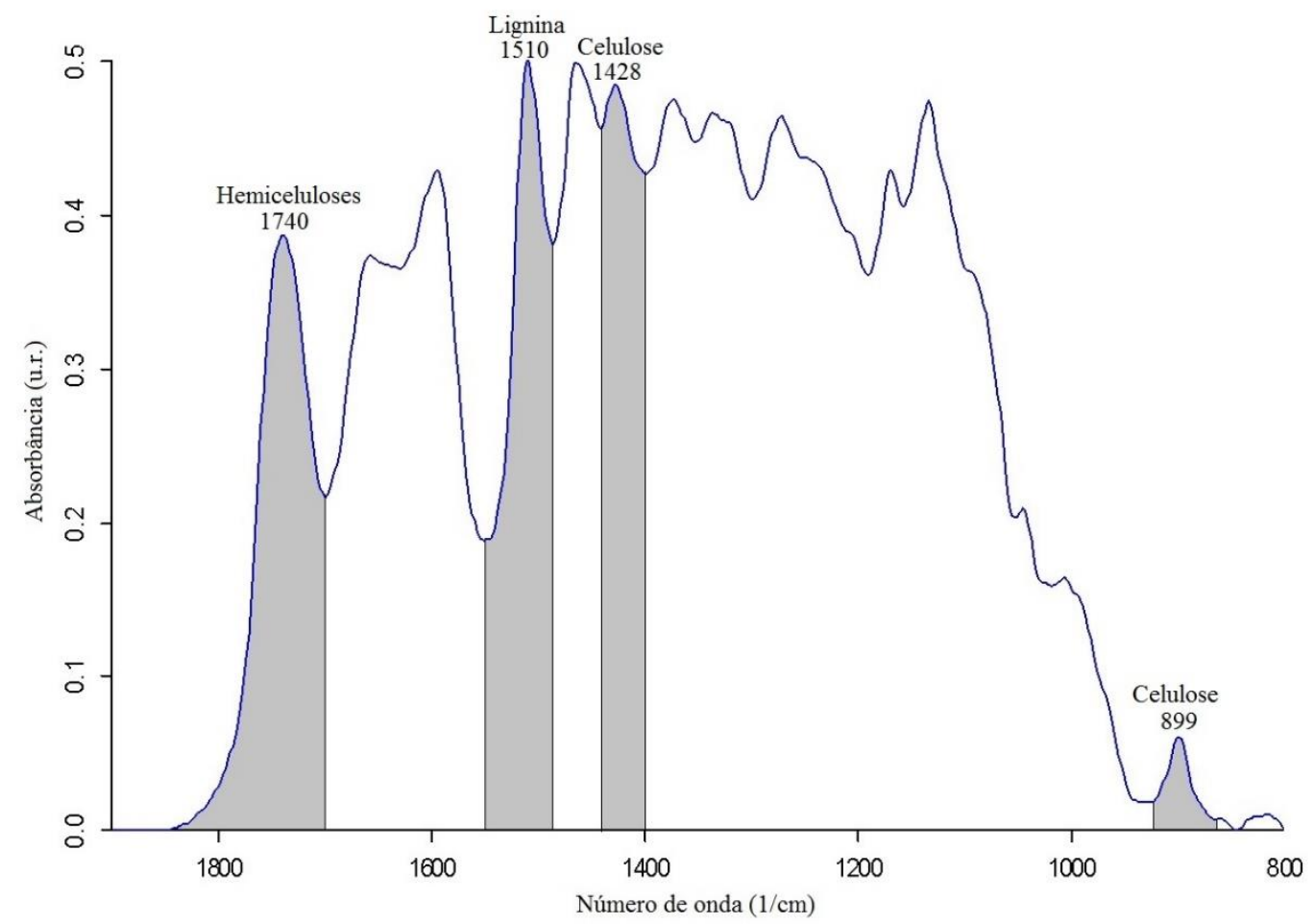

Figura 6.12 Seleção de bandas na região espectral de 1900 a $800 \mathrm{~cm}^{-1}$ para a madeira sadia de Simarouba amara. 


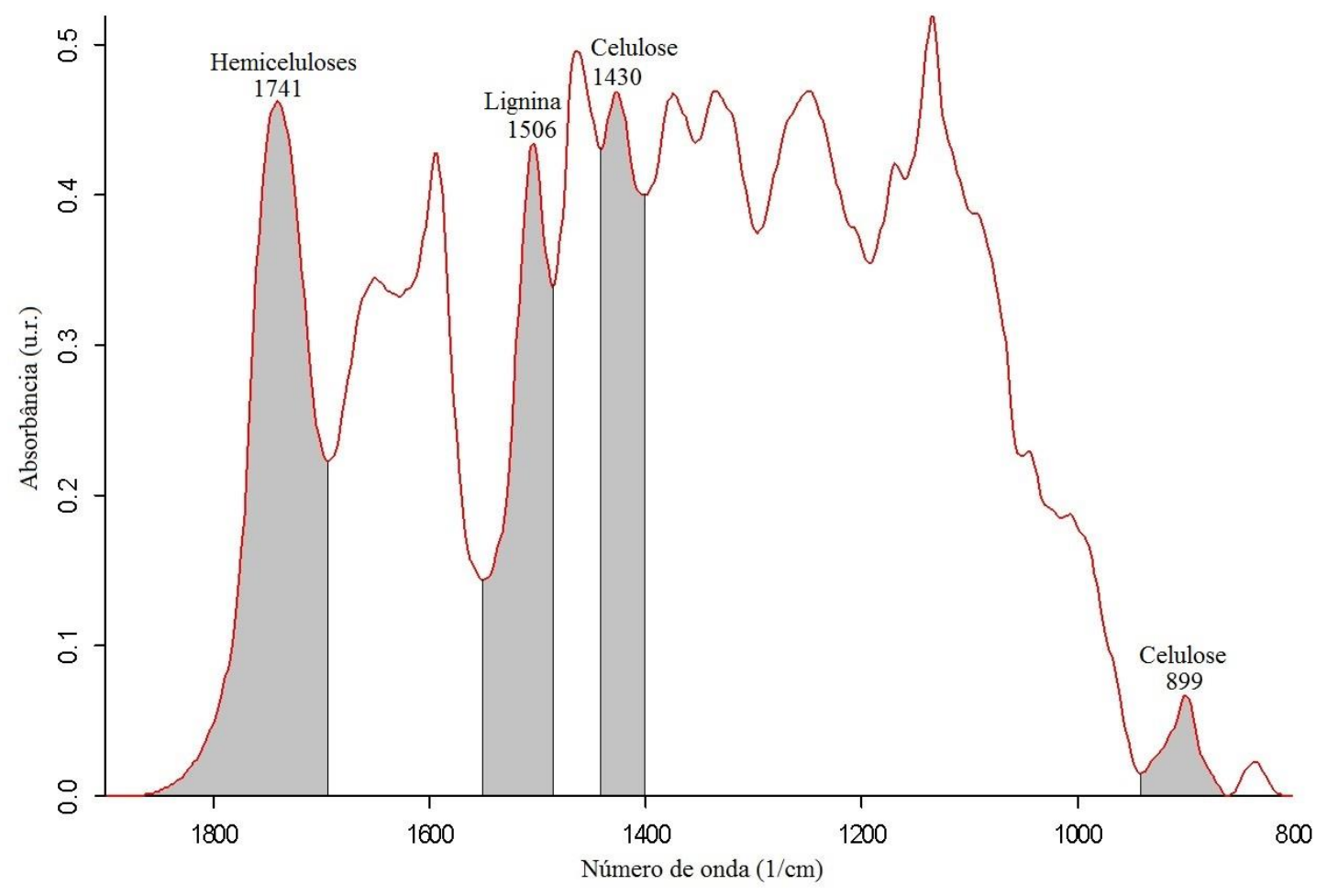

Figura 6.13 Seleção de bandas na região espectral de 1900 a $800 \mathrm{~cm}^{-1}$ para a madeira sadia de Eucalyptus saligna.

A área das bandas foi medida seguindo o procedimento ilustrado nas Figuras 6.12 e 6.13. A banda em $1740 \mathrm{~cm}^{-1}$ (Simarouba amara) e em $1741 \mathrm{~cm}^{-1}$ (Eucalyptus saligna) foi atribuída às ligações $\mathrm{C}=\mathrm{O}$ não conjugadas presentes em hemiceluloses. A banda em $1510 \mathrm{~cm}^{-1}$ (Simarouba amara) e $1506 \mathrm{~cm}^{-1}$ (Eucalyptus saligna) foi atribuída às ligações $\mathrm{C}=\mathrm{C}$ presentes em anéis aromáticos formadores da lignina. A banda em $1428 \mathrm{~cm}^{-1}$ (Simarouba amara) e em $1430 \mathrm{~cm}^{-1}$ (Eucalyptus saligna) foi atribuída às deformações assimétricas $\mathrm{CH}_{2}$ presentes na molécula de celulose. Por sua vez, a banda em $899 \mathrm{~cm}^{-1}$ (Simarouba amara e Eucalyptus saligna) foi atribuída às deformações angulares C-H presentes em celulose. (PANDEY, 1999; COLOM et al., 2003; PANDEY; PITMAN, 2003; FACKLER et al., 2007)

Segundo Fackler et al. (2007), a espetroscopia no infravermelho médio fornece informação representativa sobre a composição de amostras sólidas de madeira e é um método confiável para monitorar mudanças qualitativas e quantitativas na madeira durante o processo de colonização por Basidiomicetos. Nesse sentido, para melhor esclarecimento acerca do processo de biodeterioração, a evolução dos espectros de infravermelho médio obtidos após monitoramento semanal das madeiras de Simarouba amara e Eucalyptus saligna expostas aos fungos apodrecedores Trametes versicolor e Gloeophyllum trabeum durante um período de 12 semanas pode ser acompanhada nas Figuras 6.14 a 6.17. 


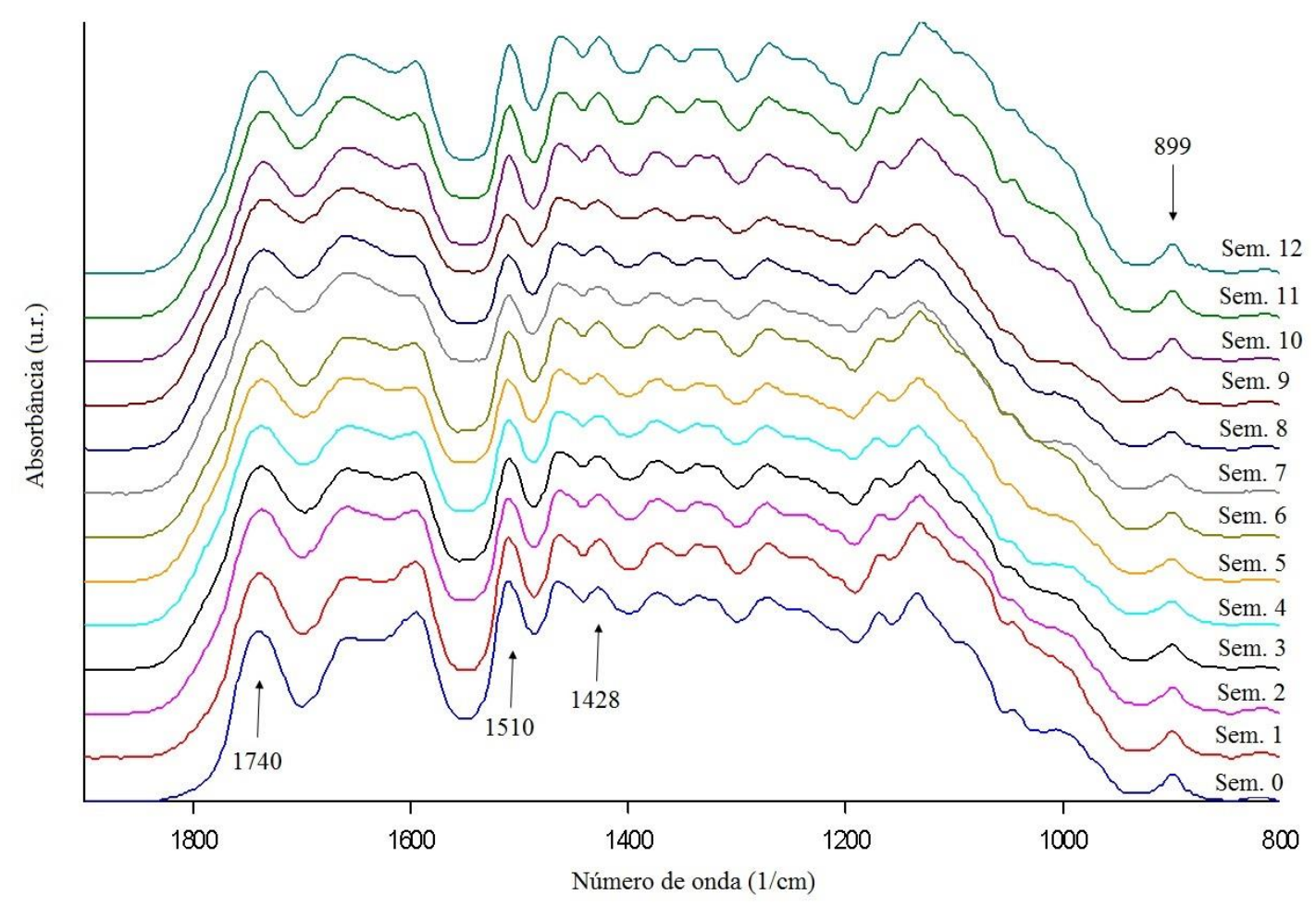

Figura 6.14 Evolução dos espectros de infravermelho médio da madeira de Simarouba amara submetida ao fungo apodrecedor Trametes versicolor durante 12 semanas.

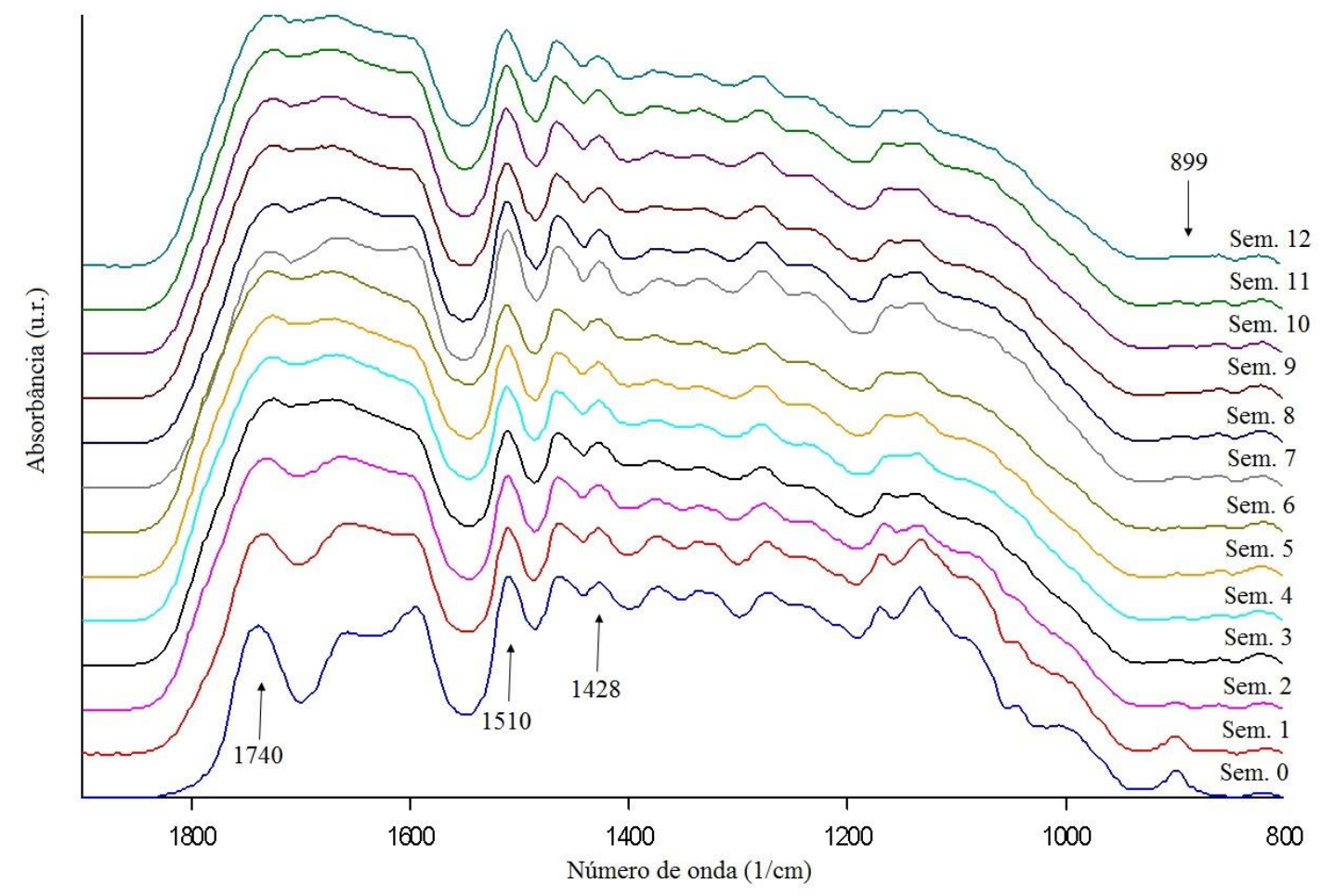

Figura 6.15 Evolução dos espectros de infravermelho médio da madeira de Simarouba amara submetida ao fungo apodrecedor Gloeophyllum trabeum durante 12 semanas. 


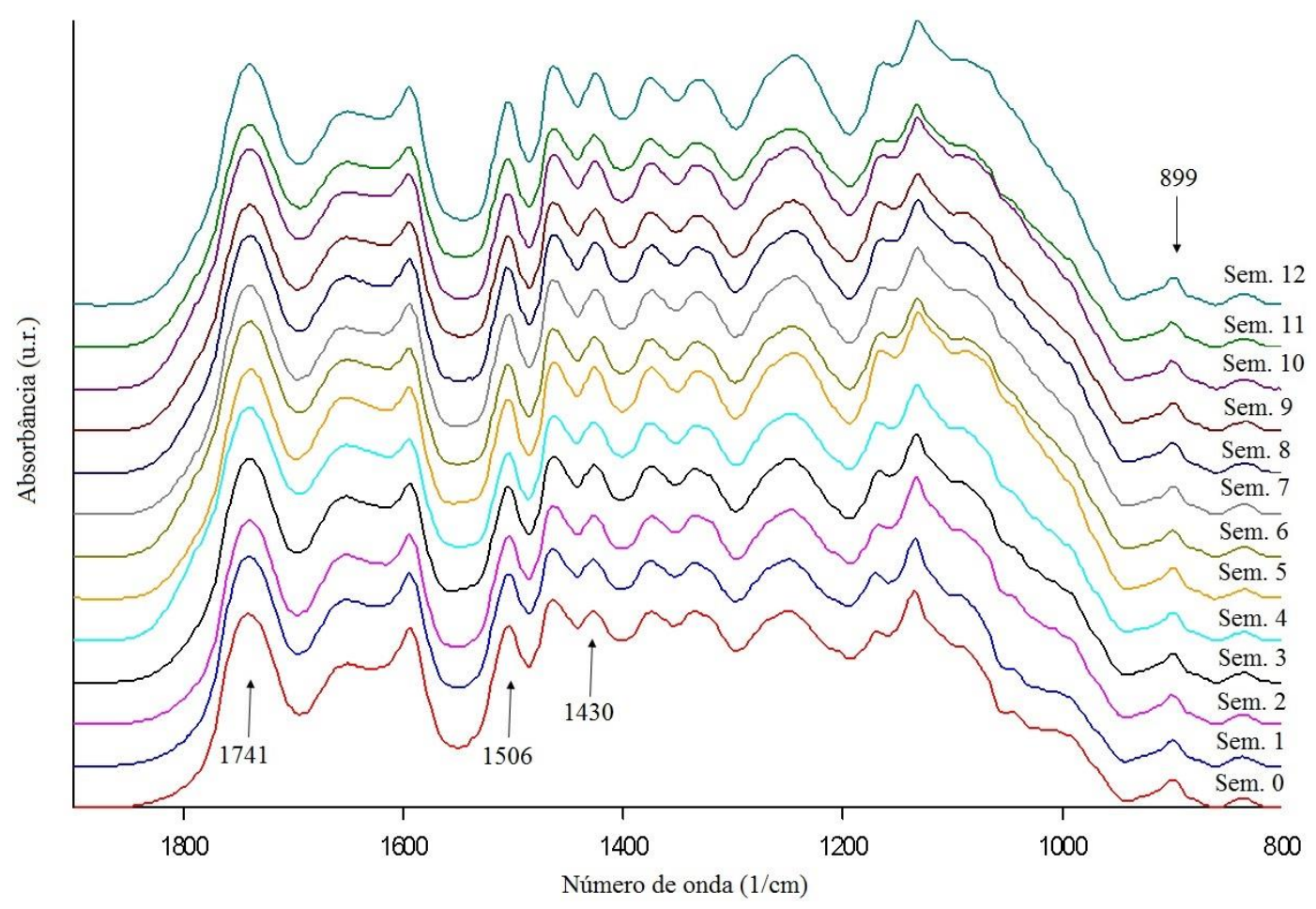

Figura 6.16 Evolução dos espectros de infravermelho médio da madeira de Eucalyptus saligna submetida ao fungo apodrecedor Trametes versicolor durante 12 semanas.

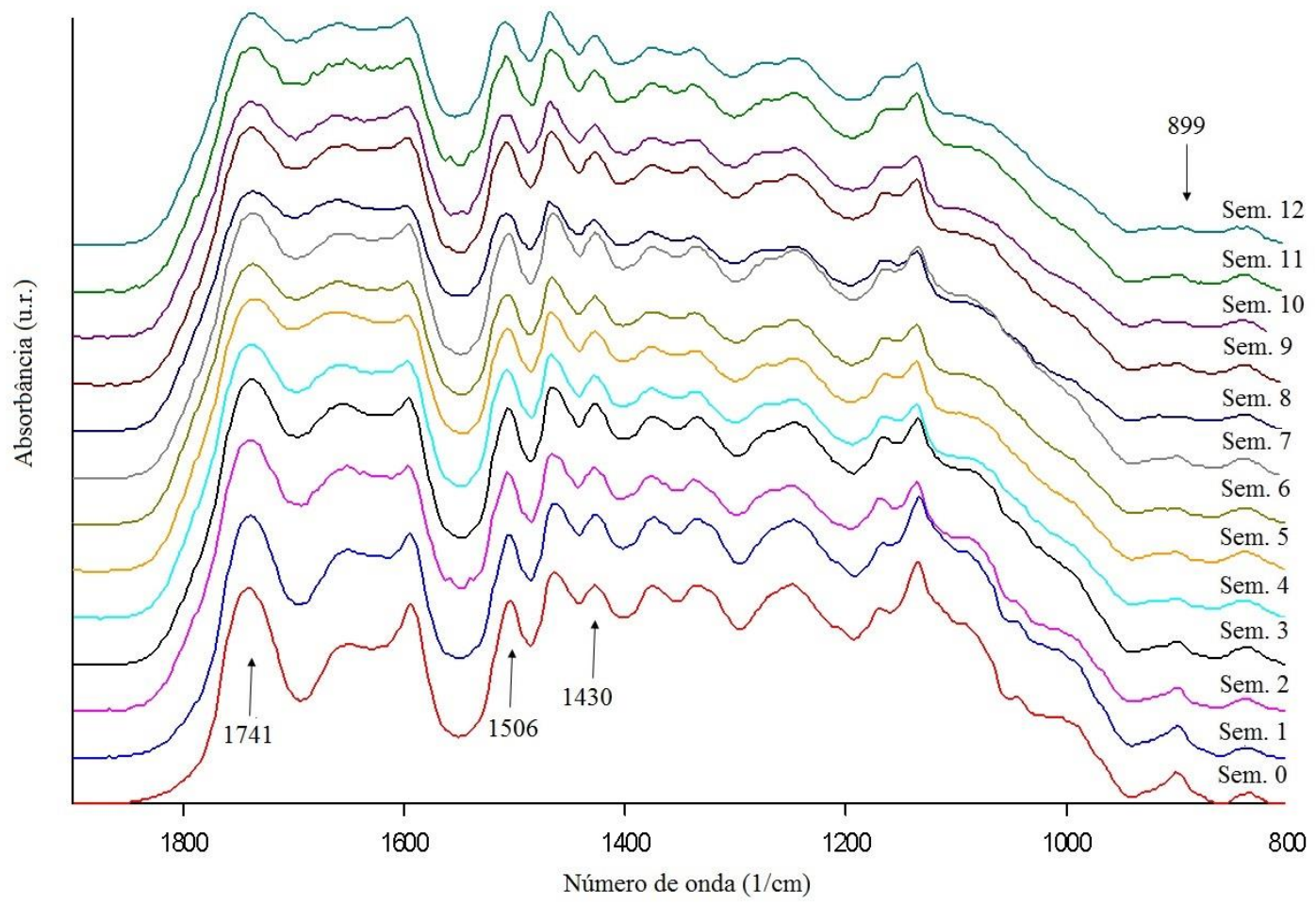

Figura 6.17 Evolução dos espectros de infravermelho médio da madeira de Eucalyptus saligna submetida ao fungo apodrecedor Gloeophyllum trabeum durante 12 semanas. 
Os espectros obtidos a cada semana durante o processo de biodeterioração mostraram de forma mais clara as semelhanças e as alterações na intensidade, na localização de picos e na definição das bandas. Isto ocorre porque a madeira, por ser um material biológico, ao ser biodeteriorada, tem sua estrutura química modificada, onde alguns compostos são destruídos ou metabolizados e outros são criados.

Os espectros médios de DRIFT para a madeira sadia e após todo o período de ensaio de apodrecimento são apresentados nas Figuras 6.18 e 6.19.

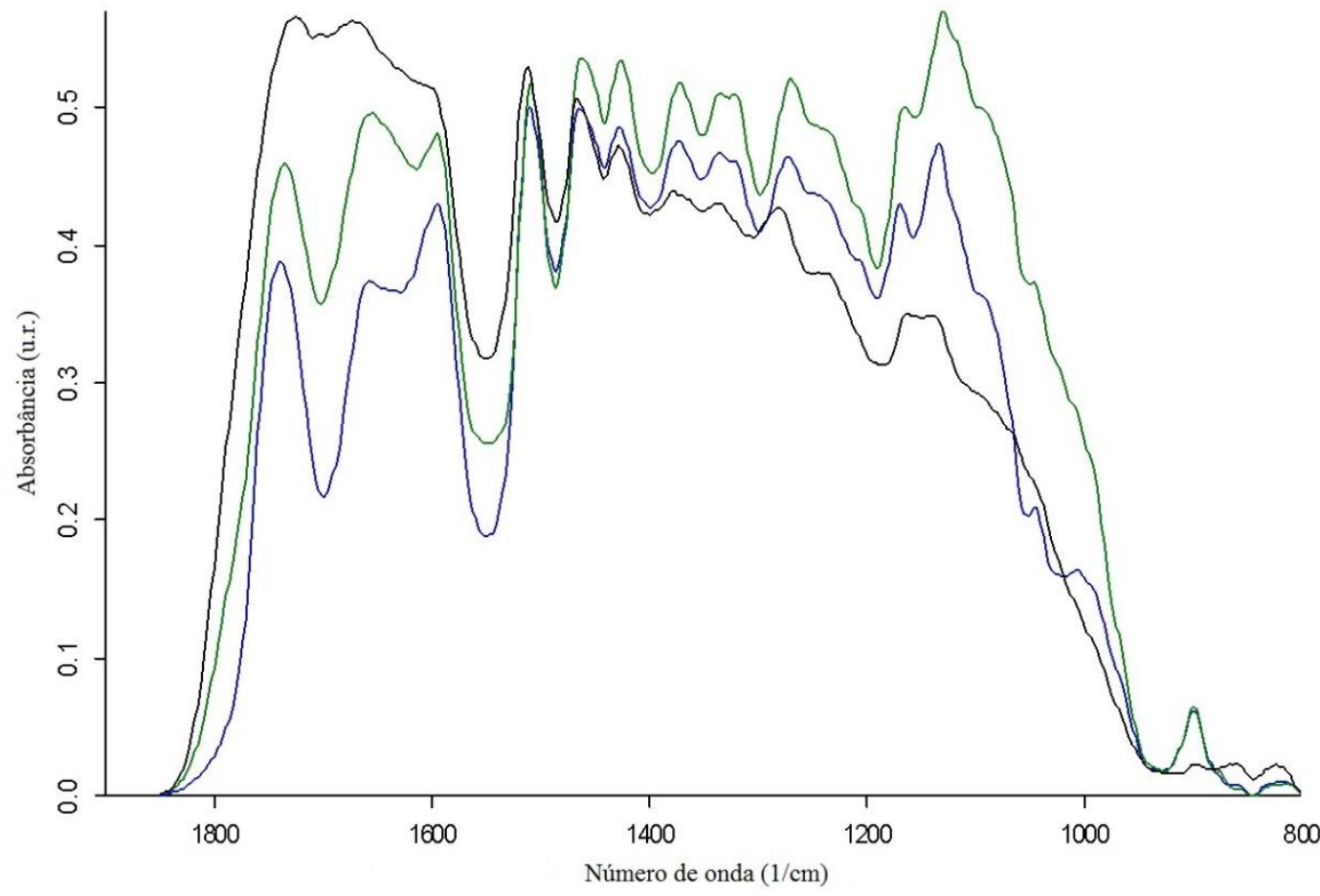

Figura 6.18 Espectros no infravermelho médio da madeira Simarouba amara sadia (azul) e após ataque dos fungos de podridão branca Trametes versicolor (verde) e podridão parda Gloeophyllum trabeum (preto). 


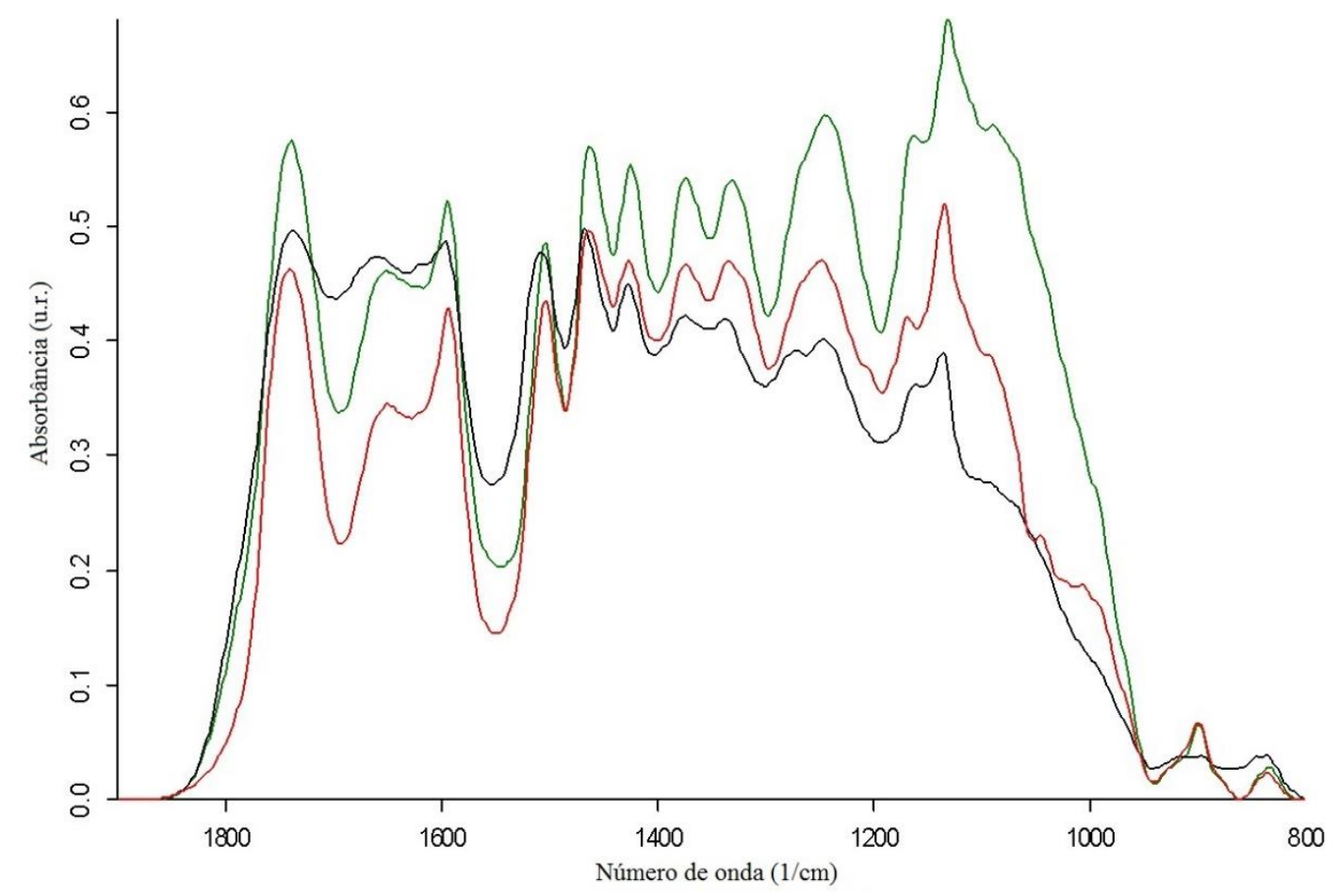

Figura 6.19 Espectros no infravermelho médio da madeira Eucalyptus saligna sadia (vermelho) e após ataque dos fungos de podridão branca Trametes versicolor (verde) e podridão parda Gloeophyllum trabeum (preto).

Verificou-se que ambas as madeiras se comportaram distintamente após o ataque dos fungos de podridão branca e parda, alterando as intensidades das bandas selecionadas, em relação à madeira sadia. Isto ocorreu devido aos diferentes mecanismos enzimáticos dos fungos. Após o ataque de Trametes versicolor, apesar da perda de massa de 42,54\% (Simarouba amara) e 23,19\% (Eucalyptus saligna), as bandas selecionadas no espectro mantiveram-se com o mesmo padrão da madeira sadia, sendo alterada apenas a intensidade das bandas, não ocorrendo sobreposição de bandas. Porém, após exposição ao fungo Gloeophyllum trabeum, os espectros apresentaram-se mais deformados, com as bandas menos definidas e intensidades alteradas, destacando-se a banda em $899 \mathrm{~cm}^{-1}$, que sofreu uma maior descaracterização. Resultados semelhantes foram descritos por Faix et al. (1991), Fackler et al. (2007), Costa (2009) e Stangerlin (2012).

Os dados de valores médios de intensidade, obtidos a partir do cálculo da área sob a curva da banda selecionada, estão expostos na Tabela 6.8 e 6.9. Ressalta-se que os dados foram normalizados em relação à madeira não atacada, ou seja, todos os valores foram divididos pela testemunha, tornando o valor desta igual a 1. Este processo visou a comparação entre 
os valores de intensidade de uma mesma banda ao longo do período de monitoramento do ataque dos fungos apodrecedores, além de facilitar a visualização para o leitor.

Tabela 6.8 Alteração de intensidades das bandas selecionadas no infravermelho médio da madeira de Simarouba amara após exposição aos fungos apodrecedores.

\begin{tabular}{ccccc|cccc}
\hline & \multicolumn{3}{c}{ Trametes versicolor } & \multicolumn{3}{c}{ Gloeophyllum trabeum } \\
\hline & Hemiceluloses & Lignina & Celulose & Celulose & Hemiceluloses & Lignina & Celulose & Celulose \\
Período & 1740 & 1510 & 1428 & 899 & 1740 & 1510 & 1428 & 899 \\
(Semanas) & $\mathrm{cm}^{-1}$ & $\mathrm{~cm}^{-1}$ & $\mathrm{~cm}^{-1}$ & $\mathrm{~cm}^{-1}$ & $\mathrm{~cm}^{-1}$ & $\mathrm{~cm}^{-1}$ & $\mathrm{~cm}^{-1}$ & $\mathrm{~cm}^{-1}$ \\
\hline 0 & 1,00 & 1,00 & 1,00 & 1,00 & 1,00 & 1,00 & 1,00 & 1,00 \\
1 & 1,22 & 0,94 & 1,01 & 0,88 & 1,58 & 1,08 & 1,04 & 0,48 \\
2 & 1,48 & 0,95 & 1,03 & 0,94 & 2,01 & 1,13 & 1,05 & 0,19 \\
3 & 1,53 & 0,93 & 1,00 & 0,95 & 1,90 & 1,15 & 1,04 & 0,18 \\
4 & 1,55 & 1,04 & 0,99 & 0,98 & 1,91 & 1,12 & 1,02 & 0,07 \\
5 & 1,55 & 0,92 & 0,98 & 0,86 & 1,89 & 1,14 & 1,00 & 0,05 \\
6 & 1,47 & 0,90 & 1,01 & 0,90 & 2,00 & 1,15 & 1,00 & 0,10 \\
7 & 1,52 & 0,84 & 0,98 & 0,62 & 1,57 & 1,25 & 1,03 & 0,31 \\
8 & 1,48 & 0,87 & 0,96 & 0,56 & 1,60 & 1,16 & 0,98 & 0,19 \\
9 & 1,60 & 0,85 & 0,97 & 0,56 & 1,76 & 1,16 & 0,98 & 0,25 \\
10 & 1,42 & 0,85 & 1,00 & 0,63 & 1,77 & 1,22 & 1,01 & 0,29 \\
11 & 1,48 & 0,86 & 1,04 & 0,80 & 1,83 & 1,20 & 1,02 & 0,23 \\
12 & 1,41 & 1,01 & 1,09 & 0,84 & 1,80 & 1,18 & 0,98 & 0,27 \\
\hline
\end{tabular}

Tabela 6.9 Alteração de intensidades das bandas selecionadas no infravermelho médio da madeira de Eucalyptus saligna após exposição aos fungos apodrecedores.

\begin{tabular}{|c|c|c|c|c|c|c|c|c|}
\hline & \multicolumn{4}{|c|}{ Trametes versicolor } & \multicolumn{4}{|c|}{ Gloeophyllum trabeum } \\
\hline $\begin{array}{c}\text { Período } \\
\text { (Semanas) }\end{array}$ & $\begin{array}{c}\text { Hemiceluloses } \\
1741 \\
\mathrm{~cm}^{-1} \\
\end{array}$ & $\begin{array}{c}\text { Lignina } \\
1506 \\
\mathrm{~cm}^{-1} \\
\end{array}$ & $\begin{array}{l}\text { Celulose } \\
1430 \\
\mathrm{~cm}^{-1} \\
\end{array}$ & $\begin{array}{c}\text { Celulose } \\
899 \\
\mathrm{~cm}^{-1} \\
\end{array}$ & \begin{tabular}{|c} 
Hemiceluloses \\
1741 \\
$\mathrm{~cm}^{-1}$ \\
\end{tabular} & $\begin{array}{c}\text { Lignina } \\
1506 \\
\mathrm{~cm}^{-1} \\
\end{array}$ & $\begin{array}{c}\text { Celulose } \\
1430 \\
\mathrm{~cm}^{-1} \\
\end{array}$ & $\begin{array}{c}\text { Celulose } \\
899 \\
\mathrm{~cm}^{-1} \\
\end{array}$ \\
\hline 0 & 1,00 & 1,00 & 1,00 & 1,00 & 1,00 & 1,00 & 1,00 & 1,00 \\
\hline 1 & 1,10 & 1,06 & 1,05 & 0,86 & 1,20 & 1,17 & 1,11 & 1,09 \\
\hline 2 & 1,05 & 1,01 & 1,05 & 1,01 & 1,45 & 1,32 & 0,94 & 0,78 \\
\hline 3 & 1,21 & 1,04 & 1,10 & 0,98 & 1,61 & 1,40 & 1,20 & 0,88 \\
\hline 4 & 1,43 & 0,98 & 1,11 & 0,98 & 1,55 & 1,39 & 1,01 & 0,81 \\
\hline 5 & 1,26 & 1,00 & 1,15 & 1,07 & 1,46 & 1,38 & 1,00 & 0,83 \\
\hline 6 & 1,40 & 0,99 & 1,11 & 0,93 & 1,55 & 1,32 & 0,95 & 0,72 \\
\hline 7 & 1,29 & 1,07 & 1,13 & 0,98 & 1,53 & 1,35 & 1,02 & 0,91 \\
\hline 8 & 1,36 & 1,02 & 1,16 & 1,14 & 1,40 & 1,29 & 0,84 & 0,76 \\
\hline 9 & 1,30 & 0,99 & 1,11 & 0,92 & 1,40 & 1,39 & 1,02 & 0,97 \\
\hline 10 & 1,45 & 1,01 & 1,14 & 0,95 & 1,38 & 1,27 & 0,98 & 0,83 \\
\hline 11 & 1,33 & 1,01 & 1,07 & 0,83 & 1,22 & 1,36 & 0,94 & 0,67 \\
\hline 12 & 1,38 & 1,08 & 1,15 & 0,88 & 1,23 & 1,30 & 0,87 & 0,84 \\
\hline
\end{tabular}


Analisando mais detalhadamente as bandas selecionadas, a partir dos dados fornecidos pelas Tabelas 6.8 e 6.9, verificou-se que, para a madeira de Simarouba amara, a intensidade da banda referentes às hemiceluloses $\left(1740 \mathrm{~cm}^{-1}\right)$ aumentou, proporcionalmente, cerca de $40 \%$ após o ataque de Trametes versicolor e em torno de $80 \%$ após o ataque de Gloeophyllum trabeum. Esta alteração expressiva pode ter provocado um envelopamento ou sobreposição das bandas mais próximas. Para a madeira de Eucalyptus saligna, após exposição a ambos os fungos apodrecedores, a intensidade da banda em $1741 \mathrm{~cm}^{-1}$ aumentou, em média, $30 \%$. Os acréscimos verificados nesta banda podem estar ligados à formação de compostos carbonílicos decorrente da deterioração das cadeias de compostos metabolizados enzimaticamente pelos fungos. Para Ferraz et al. (2000), este aumento pode estar relacionado a novos ácidos não conjugados presentes na cadeia lateral da macromolécula de lignina ou à resistência à biodeterioração de ácidos urônicos e estruturas de grupos acetila ramificados em polioses.

No geral, a intensidade da banda de lignina para ambas as espécies de madeira (1510 e 1506 $\mathrm{cm}^{-1}$ ) aumentou de maneira discreta após o ataque de Trametes versicolor e de forma mais expressiva, em torno de $20 \%$, após as madeiras serem submetidas ao fungo Gloeophyllum trabeum. Isto não significa que a quantidade de lignina aumentou, mas que a proporção deste composto em relação à celulose, por exemplo, passou a ser maior em função do processo de biodeterioração. Fungos de podridão parda deterioram seletivamente os carboidratos estruturais, degradando a lignina de forma limitada, permanecendo este componente em maior quantidade (PANDEY; PITMAN, 2003). Ao observar especificamente a madeira de Simarouba amara, ao final do período de exposição das amostras ao fungo de podridão branca, foi detectado um leve acréscimo na banda de lignina, porém, durante o monitoramento foi verificada uma tendência de decréscimo. Isto confirma o mecanismo não seletivo (ou simultâneo) deste fungo, que remove lignina e carboidratos estruturais, resultando em uma deterioração homogênea da parede celular (PANDEY; NAGVENI, 2007).

Ao serem submetidas ao fungo de podridão branca Trametes versicolor, as madeiras de Simarouba amara e Eucalyptus saligna apresentaram um discreto aumento na intensidade da banda de celulose em $1428 \mathrm{~cm}^{-1} \mathrm{e} 1430 \mathrm{~cm}^{-1}$. A explicação para este acréscimo é a relação proporcional entre os compostos químicos da madeira antes e após a sua deterioração. Entretanto, após o ataque do fungo de podridão parda Gloeophyllum trabeum, foram 
detectadas reduções nas intensidades desta banda, ocorrendo de forma mais significativa na madeira de Eucalyptus saligna.

A celulose em $899 \mathrm{~cm}^{-1}$ foi o composto mais alterado em ambas as espécies de madeiras, o que pode ser observado pela intensa descaracterização da banda no espectro. Na madeira de Simarouba amara, submetida ao fungo Trametes versicolor, foi detectada uma redução na intensidade em torno de 15\%, enquanto que após o ataque de Gloeophyllum trabeum o decréscimo foi de mais de 70\%. Em Eucalyptus saligna, uma redução de 15\% na intensidade da banda foi verificada após exposição a ambos os fungos apodrecedores. Em função da preferência em assimilar carboidratos e da menor massa específica, pode ser explicada a intensa degradação da celulose em Simarouba amara após o ataque de podridão parda.

Em resumo, o fungo de podridão parda Gloeophyllum trabeum metabolizou as cadeias de celulose localizadas em $1428 \mathrm{~cm}^{-1}$ (Simarouba amara), $1430 \mathrm{~cm}^{-1}$ (Eucalyptus saligna) e $899 \mathrm{~cm}^{-1}$ (ambas as espécies de madeira), enquanto que o fungo de podridão branca preferiu a banda em $899 \mathrm{~cm}^{-1}$.

Assim, de modo geral, os resultados espectrais indicaram que a madeira de Eucalyptus saligna sofreu alterações em menor escala, e isso pode ser atribuído à sua maior massa específica e à maior quantidade de extrativos presentes nesta espécie em relação à madeira de Simarouba amara.

Pandey e Nagveni (2007) analisaram dados espectrais no infravermelho da madeira de Hevea brasiliensis após ser submetida ao fungo Trametes versicolor e verificaram uma redução na intensidade da banda referente à lignina em $1505 \mathrm{~cm}^{-1}$ e alterações pouco pronunciadas na banda de celulose em $898 \mathrm{~cm}^{-1}$, corroborando os resultados deste estudo.

Costa (2009) e Stangerlin (2012) estudaram a madeira de Simarouba amara após ser submetida ao fungo Trametes versicolor, e constataram um acréscimo na banda em 1735 $\mathrm{cm}^{-1}$, e reduções de intensidade nas bandas em $1510 \mathrm{~cm}^{-1}$ e $899 \mathrm{~cm}^{-1}$. No caso de exposição ao fungo Gloeophyllum trabeum, foi verificado um aumento de intensidade em $1735 \mathrm{~cm}^{-1}$, redução bastante significativa em $899 \mathrm{~cm}^{-1}$, enquanto que a intensidade registrada da banda em $1510 \mathrm{~cm}^{-1}$ aumentou no estudo de Costa (2009) e reduziu no estudo de Stangerlin (2012). Estes resultados estão de acordo com os descritos no presente estudo.

Facker et al. (2007), ao estudar as alterações ocorridas na madeira de Fagus sylvatica L. exposta a fungos de podridão branca Trametes versicolor e parda Gloeophyllum trabeum, 
relataram um acréscimo na banda em $1738 \mathrm{~cm}^{-1}$, porém em intensidade menor que o esperado. No entanto, este acréscimo pode ser causado por processos oxidativos, não significando um aumento relativo de hemiceluloses. Estes mesmos autores observaram acréscimos na banda de lignina em $1505 \mathrm{~cm}^{-1}$ e poucas alterações na banda de celulose em $898 \mathrm{~cm}^{-1}$, corroborando os resultados deste estudo.

Faix et al. (1991) também estudaram a madeira de Fagus sylvatica L. submetida a Trametes versicolor, e relataram que a área entre 1200 e $900 \mathrm{~cm}^{-1}$, ligada à presença de polissacarídeos, apresentou poucas alterações no espectro de infravermelho, além de decréscimo na banda referente à lignina em $1506 \mathrm{~cm}^{-1}$, sugerindo mudanças estruturais e perda de unidades aromáticas durante a deterioração fúngica. Estes resultados estão de acordo com os obtidos neste estudo, destacando a tendência de decréscimo na banda de lignina em Simarouba amara.

Os valores de correlação entre as alterações nos parâmetros químicos, o período de exposição aos fungos apodrecedores e a perda de massa estão apresentados na Tabelas 6.10 e 6.11 .

Tabela 6.10 Correlação entre as alterações químicas, o período de exposição aos fungos e a perda de massa da madeira de Simarouba amara.

\begin{tabular}{|c|c|c|c|c|}
\hline \multicolumn{5}{|c|}{ Trametes versicolor } \\
\hline & $1740 \mathrm{~cm}^{-1}$ & $1510 \mathrm{~cm}^{-1}$ & $1428 \mathrm{~cm}^{-1}$ & $899 \mathrm{~cm}^{-1}$ \\
\hline Período (Semanas) & $0,47^{\mathrm{NS}}$ & $-0,46^{\mathrm{NS}}$ & $0,22^{\mathrm{NS}}$ & $-0,64 *$ \\
\hline Perda de massa (\%) & $0,49^{\mathrm{NS}}$ & $-0,44^{\mathrm{NS}}$ & $0,20^{\mathrm{NS}}$ & $-0,62 *$ \\
\hline \multicolumn{5}{|c|}{ Gloeophyllum trabeum } \\
\hline & $1740 \mathrm{~cm}^{-1}$ & $1510 \mathrm{~cm}^{-1}$ & $1428 \mathrm{~cm}^{-1}$ & $899 \mathrm{~cm}^{-1}$ \\
\hline Período (Semanas) & $0,30^{\mathrm{NS}}$ & $0,77 * *$ & $-0,52^{\mathrm{NS}}$ & $-0,40^{\mathrm{NS}}$ \\
\hline Perda de massa (\%) & $0,36^{\mathrm{NS}}$ & $0,80 * *$ & $-0,52^{\mathrm{NS}}$ & $-0,48^{\mathrm{NS}}$ \\
\hline
\end{tabular}

Em que: $* *=$ significativo a $1 \% ; *=$ significativo a $5 \% ;{ }^{\text {NS }}=$ não significativo. 
Tabela 6.11 Correlação entre as alterações químicas, o período de exposição aos fungos e a perda de massa da madeira de Eucalyptus saligna.

\section{Trametes versicolor}

\begin{tabular}{lcccc}
\hline & $1741 \mathrm{~cm}^{-1}$ & $1506 \mathrm{~cm}^{-1}$ & $1430 \mathrm{~cm}^{-1}$ & $899 \mathrm{~cm}^{-1}$ \\
\hline Período (Semanas) & $0,76^{* *}$ & $0,12^{\mathrm{NS}}$ & $0,65^{*}$ & $-0,25^{\mathrm{NS}}$ \\
\hline Perda de massa (\%) & $0,75^{* *}$ & $0,11^{\mathrm{NS}}$ & $0,59^{*}$ & $-0,34^{\mathrm{NS}}$ \\
\hline \multicolumn{5}{c}{ Gloeophyllum trabeum } \\
\hline Período (Semanas) & $0,04^{\mathrm{NS}}$ & $0,44^{\mathrm{NS}}$ & $-0,55^{\mathrm{NS}}$ & $-0,47^{\mathrm{NS}}$ \\
\hline Perda de massa (\%) & $0,04^{\mathrm{NS}}$ & $0,41^{\mathrm{NS}}$ & $-0,57^{*}$ & $-0,49^{\mathrm{NS}}$ \\
\hline
\end{tabular}

Em que: $* *=$ significativo a $1 \% ; *=$ significativo a $5 \% ;{ }^{\mathrm{NS}}=$ não significativo.

Verificou-se que, para a madeira de Simarouba amara, houve correlação negativa e significativa para a banda de celulose em $899 \mathrm{~cm}^{-1}$ após o ataque de Trametes versicolor, enquanto que após o ataque de Gloeophyllum trabeum só foi observada correlação significativa para as alterações na banda referente à lignina em $1510 \mathrm{~cm}^{-1}$.

Para a madeira de Eucalyptus saligna submetida ao fungo Trametes versicolor, foram observadas correlações positivas e significativas nas bandas em $1741 \mathrm{~cm}^{-1}$ (hemiceluloses) e em $1430 \mathrm{~cm}^{-1}$ (celulose). Apenas uma correlação significativa foi verificada após o ataque de Gloeophyllum trabeum, também na banda em $1430 \mathrm{~cm}^{-1}$ (celulose).

\subsubsection{Fluorescência molecular}

As Figuras 6.20 a 6.23 apresentam o comportamento da fluorescência emitida pelas madeiras de Simarouba amara e Eucalyptus saligna após 12 semanas de exposição aos fungos apodrecedores. 


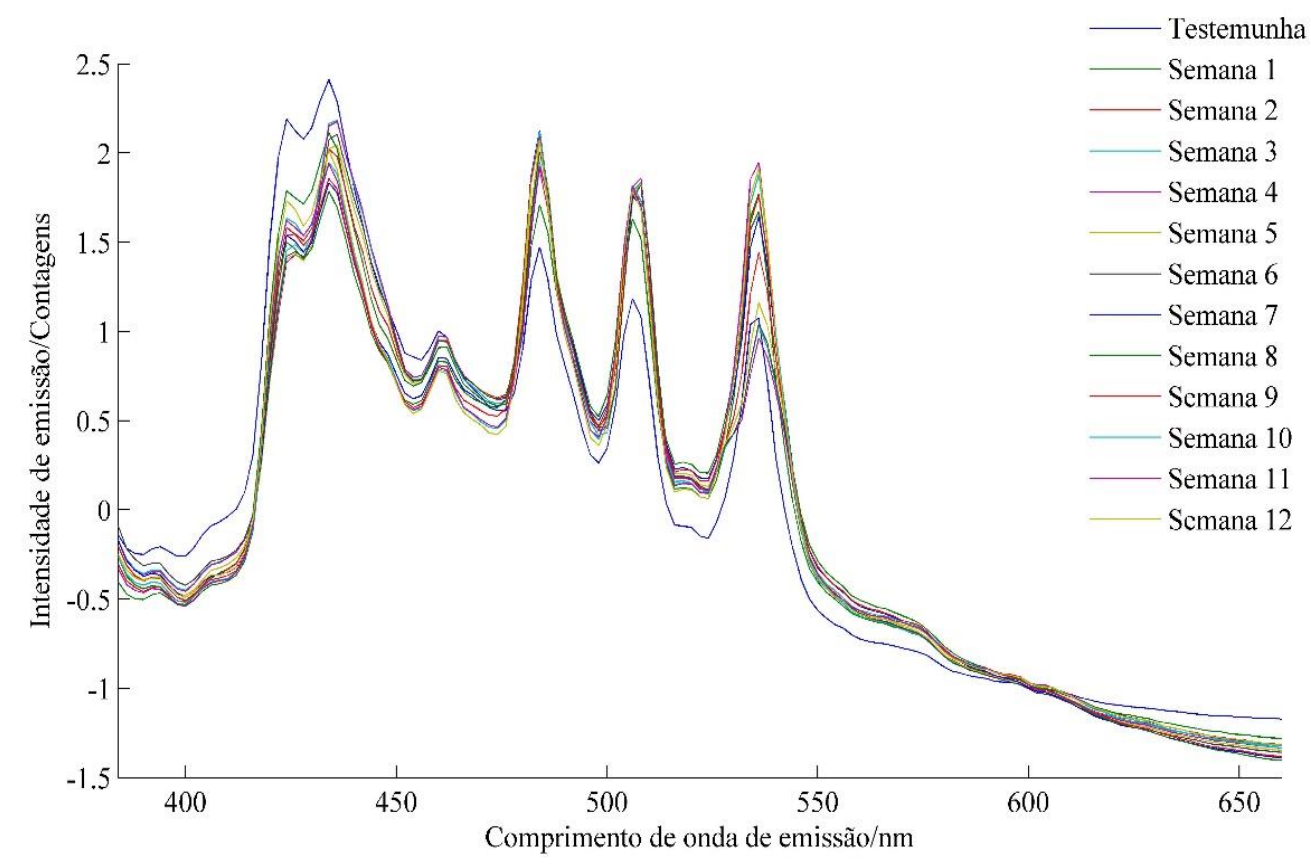

Figura 6.20 Espectros de emissão de fluorescência obtidos por excitação em $370 \mathrm{~nm}$ das amostras de Simarouba amara após 12 semanas de exposição ao fungo Trametes versicolor.

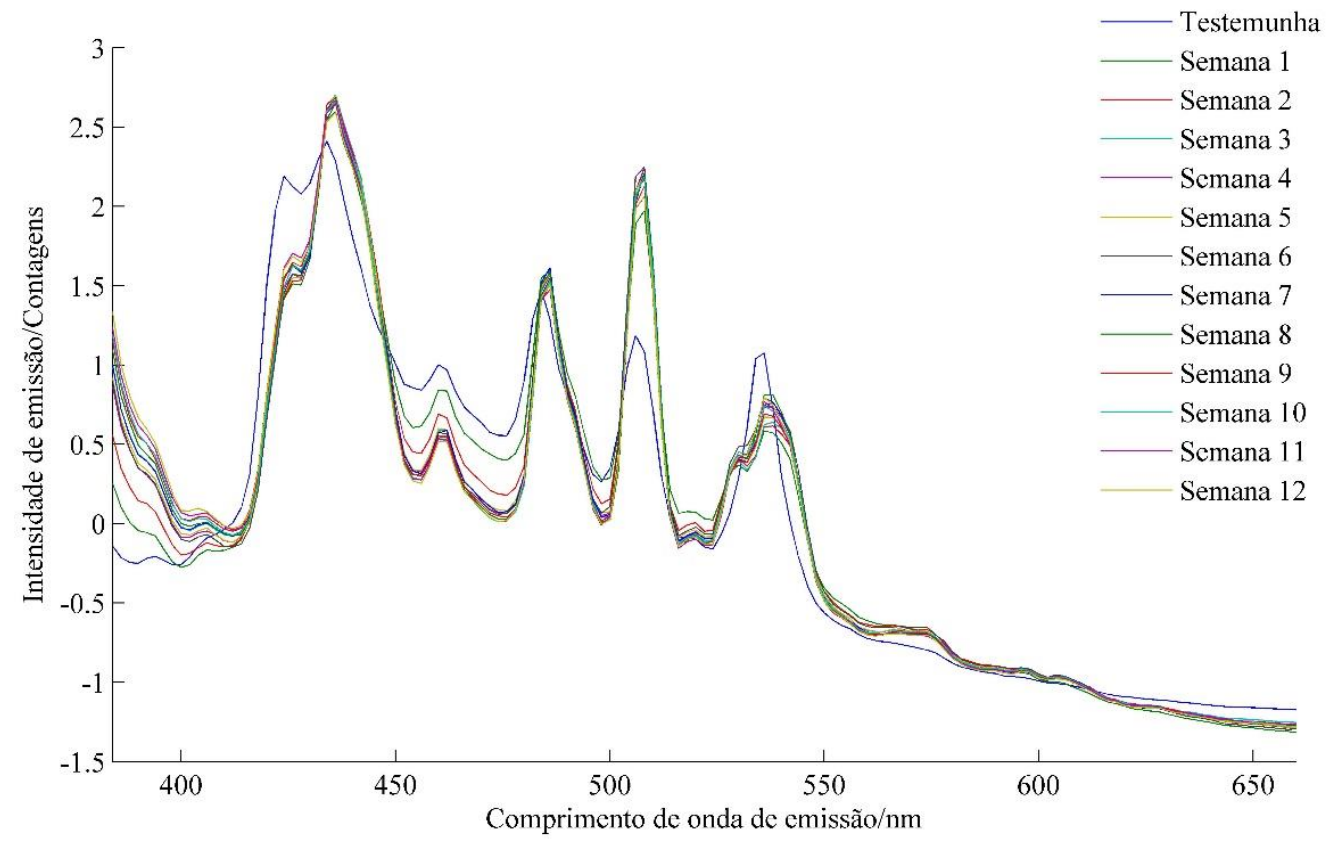

Figura 6.21 Espectros de emissão de fluorescência obtidos por excitação em $370 \mathrm{~nm}$ das amostras de Simarouba amara após 12 semanas de exposição ao fungo Gloeophyllum trabeum. 


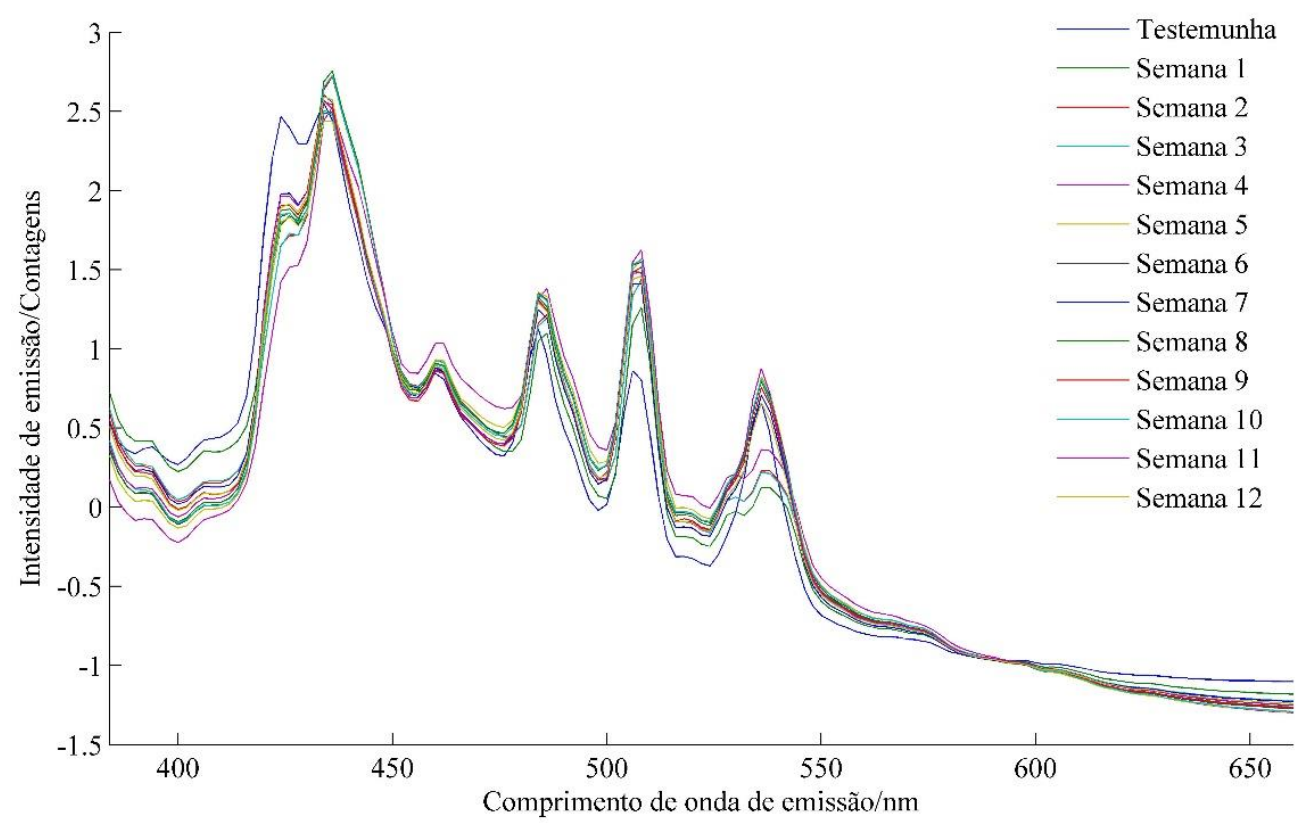

Figura 6.22 Espectros de emissão de fluorescência obtidos por excitação em $370 \mathrm{~nm}$ das amostras de Eucalyptus saligna após 12 semanas de exposição ao fungo Trametes versicolor.

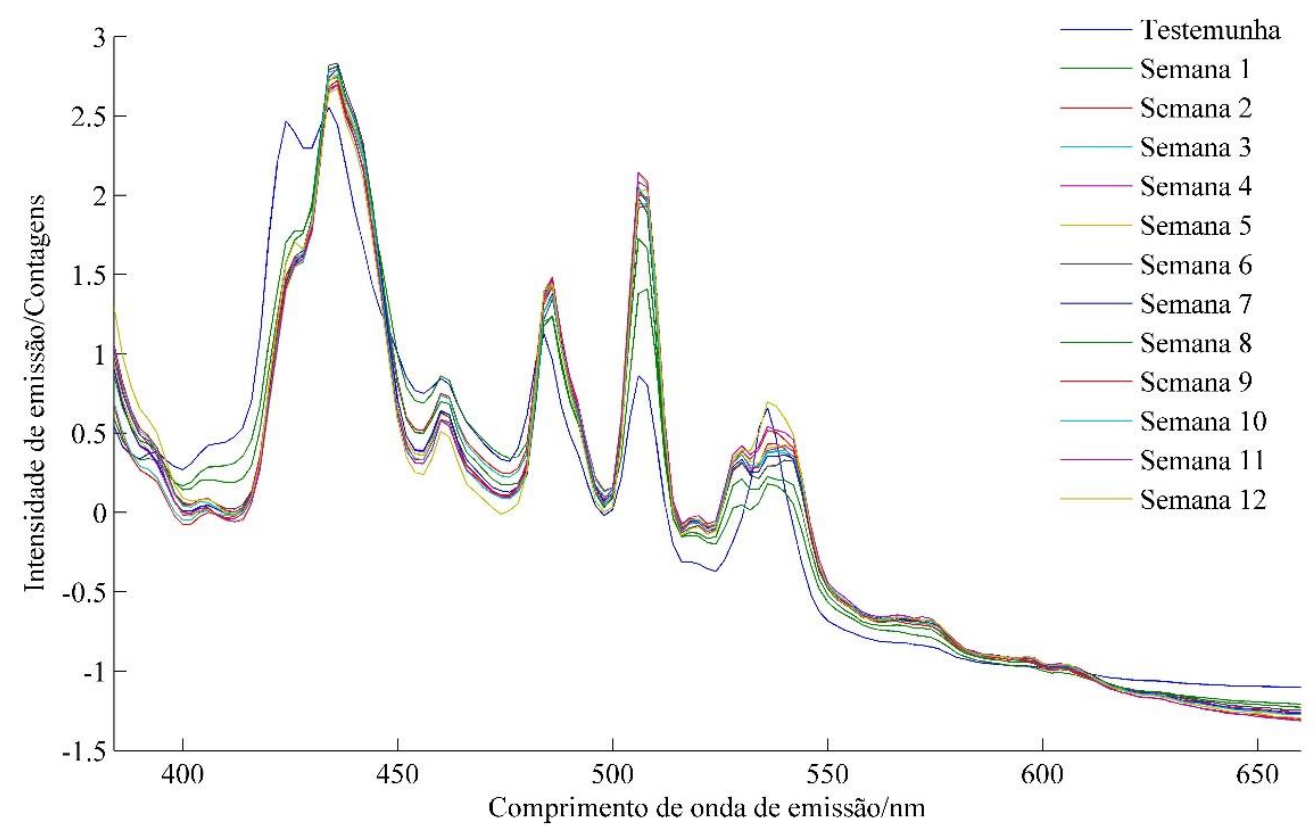

Figura 6.23 Espectros de emissão de fluorescência obtidos por excitação em $370 \mathrm{~nm}$ das amostras de Eucalyptus saligna após 12 semanas de exposição ao fungo Gloeophyllum trabeum. 
A partir da análise dos gráficos de intensidade de fluorescência emitida, observa-se que após o ataque dos fungos apodrecedores as duas espécies de madeira apresentam espectros semelhantes, com as mesmas bandas de emissão. Porém, dependendo da semana analisada, a intensidade de emissão nessas bandas foi alterada, sofrendo incrementos ou reduções. Esta análise pode ser, de certa maneira, generalizada, não possibilitando discriminar, de maneira segura, o comportamento dos fungos apodrecedores ao atacar uma determinada espécie de madeira.

Os dendrogramas, obtidos por meio da análise de Cluster, apresentados nas Figuras 6.24 e 6.25 mostram os agrupamentos das semanas "mais semelhantes" pelo critério da variância mínima de Ward. Tais agrupamentos são formados de modo a minimizar a variação das intensidades de emissão de fluorescência dentro dos subgrupos e maximizar a variação entre os subgrupos.

As amostras de Simarouba amara e Eucalyptus saligna atacadas por Trametes versicolor e retiradas semanalmente, durante 12 semanas, estão representadas pelos números 2 (referente à semana 1) a 13 (referente à semana 12). As amostras destas espécies de madeira expostas ao fungo Gloeophyllum trabeum estão representadas pelos números 14 (referente à semana 1) a 25 (referente à semana 12). Por sua vez, as amostras testemunhas estão representadas no dendrograma pelo número 1 .

A partir da análise dos dendrogramas, verificou-se uma clara distinção entre o ataque dos fungos de podridão parda e branca, em função das intensidades de fluorescência medidas. Para a madeira de Simarouba amara, a diferenciação entre o ataque dos fungos começou a ser observada logo na primeira semana, uma vez que as amostras atacadas pelo fungo Gloeophyllum trabeum já se apresentaram diferenciadas das amostras testemunhas (representadas pelo número 1). Entretanto, as amostras atacadas pelo fungo Trametes versicolor somente apresentaram diferenças a partir da segunda semana e mantiveram esta condição até a sexta semana de ensaio. Após este período, as amostras voltaram a emitir sinal de fluorescência semelhante às amostras não submetidas aos fungos. 


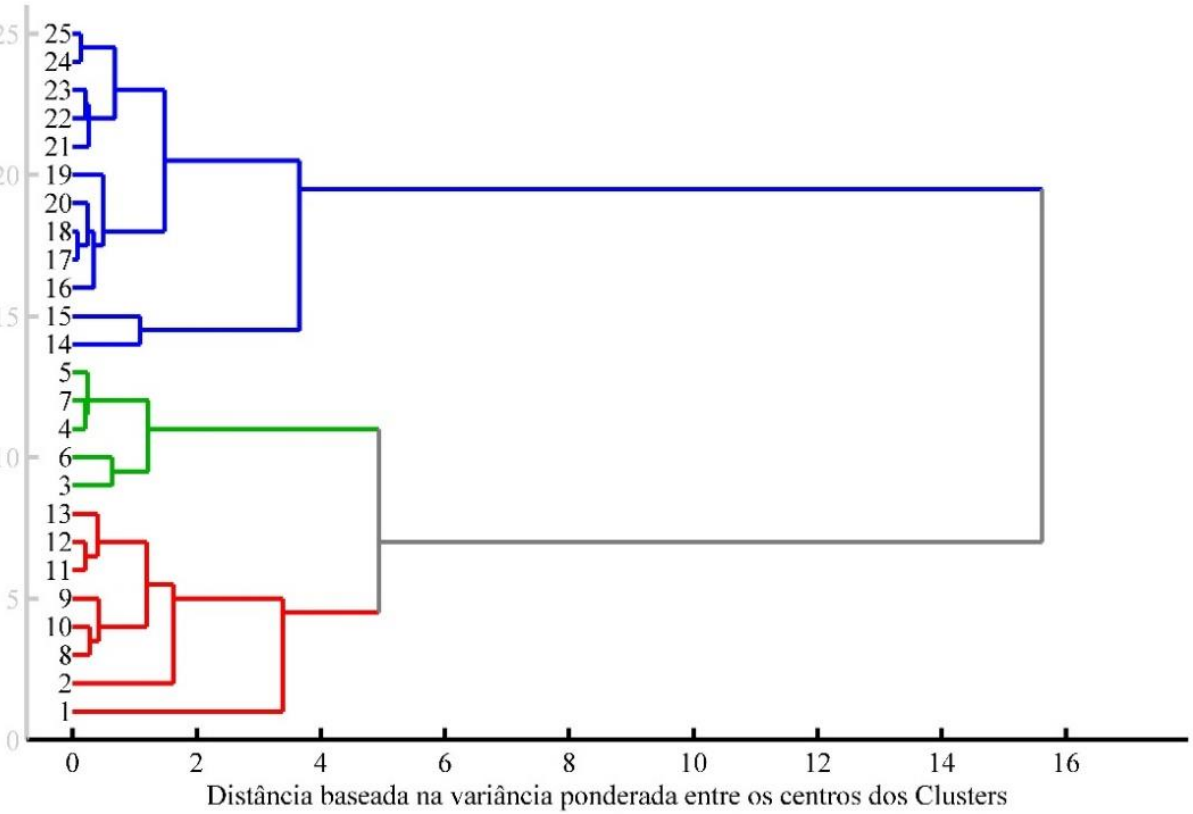

Figura 6.24 Dendrograma da madeira de Simarouba amara submetida aos fungos Trametes versicolor (2-13) e Gloeophyllum trabeum (14-25).

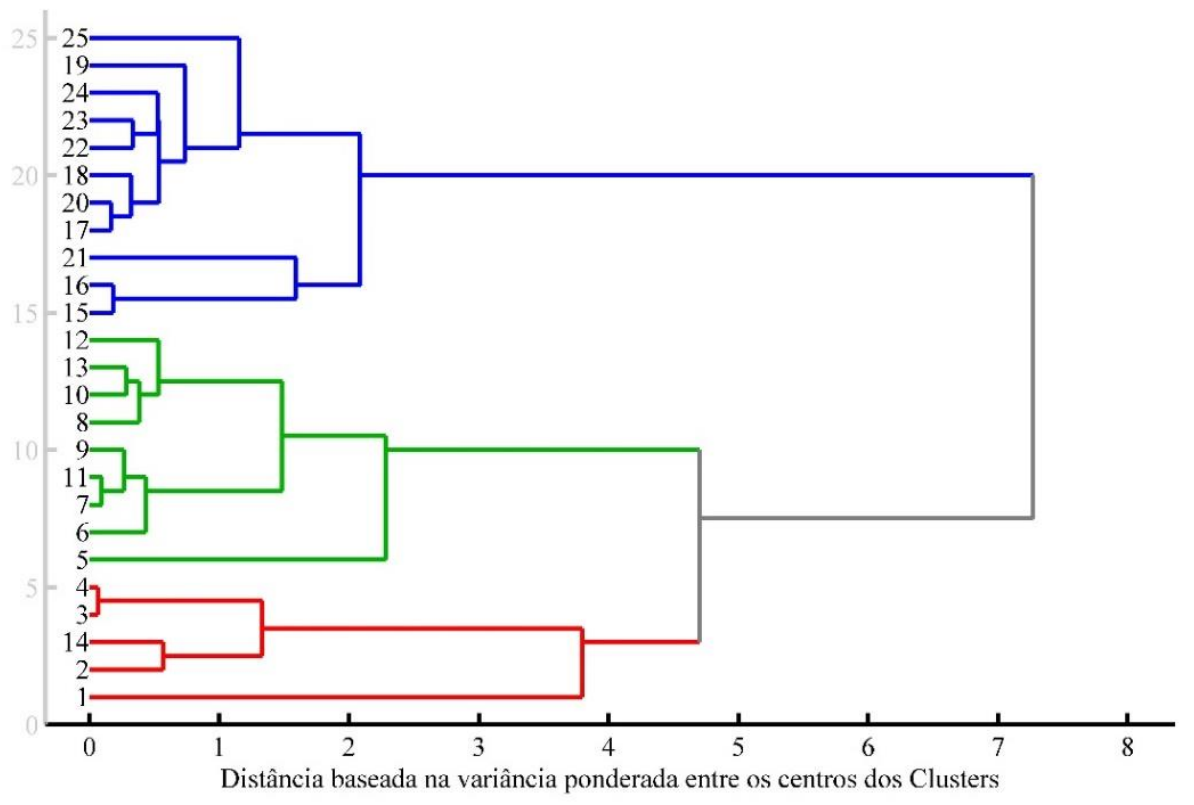

Figura 6.25 Dendrograma da madeira de Eucalyptus saligna submetida aos fungos Trametes versicolor (2-13) e Gloeophyllum trabeum (14-25).

Na madeira de Eucalyptus saligna, a diferenciação de ataque entre os fungos passou a ser observada a partir da segunda semana, pois o fungo de podridão parda Gloeophyllum trabeum proporcionou uma emissão de fluorescência significativamente diferente das 
amostras testemunhas. O fungo de podridão branca Trametes versicolor só apresentou uma intensidade de fluorescência emitida, significativamente diferente das testemunhas, a partir da quarta semana de ataque.

E, apesar do dendrograma permitir a visualização dos distintos ataques dos fungos apodrecedores, não se percebe um padrão muito claro do que acontece com a fluorescência emitida, semana a semana, para cada espécie de madeira estudada, podendo-se inferir apenas tendências de comportamento.

Os gráficos de escores, obtidos após a análise de componentes principais (PCA, do inglês Principal Components Analysis), apresentados nas Figuras 6.26 e 6.28 fornecem a composição das componentes principais (PC, do inglês Principal Components) em relação às amostras, antes e após o ataque dos fungos apodrecedores.

Para explicar 98,42\% do comportamento da fluorescência após o ataque de ambos os fungos apodrecedores à madeira de Simarouba amara foram necessárias três componentes principais. O gráfico destaca as semelhanças entre as amostras atacadas por Trametes versicolor e as amostras testemunhas, todas representadas pelo ícone vermelho, além da distinção entre o ataque de podridão branca (ícone verde) e parda (ícone azul).

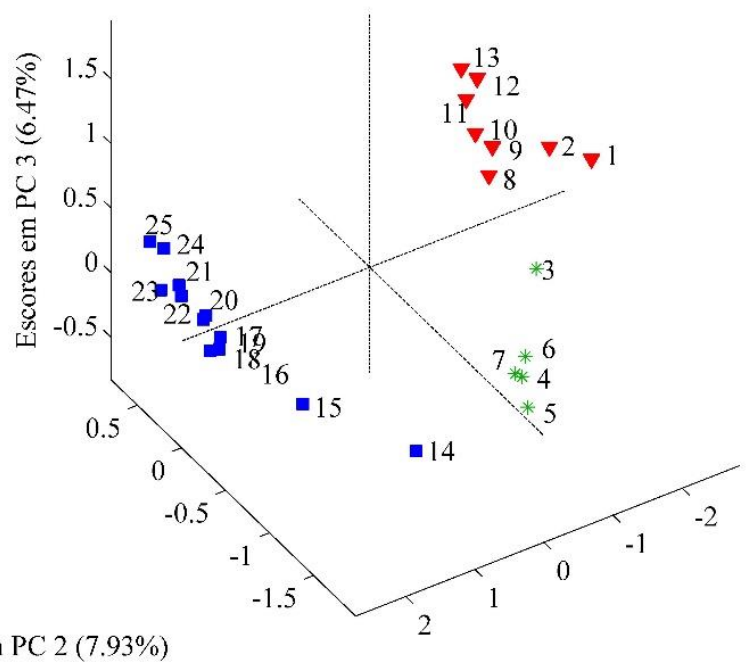

Escores em PC 2 (7.93\%)

Fscores em PC $1(84.02 \%)$

Figura 6.26 Gráfico de escores obtido para a madeira de Simarouba amara após o ataque de Trametes versicolor (2-13) e Gloeophyllum trabeum (14-25). 
Ao observar a componente principal 1, apresentada na Figura 6.27, que é responsável por $84,02 \%$ da disposição das amostras, é clara a separação entre as amostras testemunhas (1) e as atacadas por podridão branca (2-13) e podridão parda (14-25).

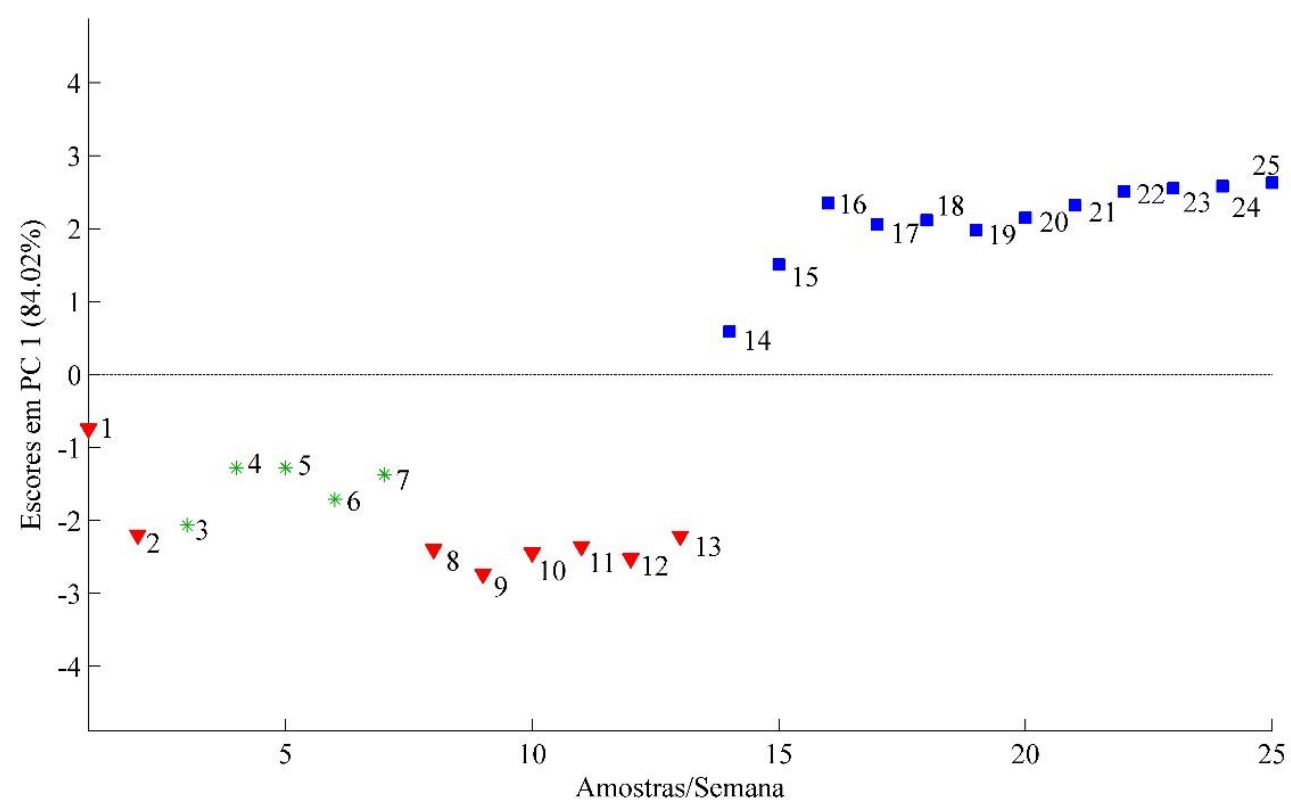

Figura 6.27 Gráfico de escores relativos à componente 1 obtido para a madeira de Simarouba amara após o ataque de Trametes versicolor (2-13) e Gloeophyllum trabeum (14-25).

Para explicar 98,12\% do comportamento da fluorescência emitida pela madeira de Eucalyptus saligna, também foram necessárias três componentes principais. O gráfico apresentado na Figura 6.28 também mostra semelhanças entre as amostras testemunhas (1) e as amostras das primeiras semanas após ataque de podridão branca e parda, representadas pelo ícone vermelho, e a separação entre os ataques dos fungos de podridão branca (ícone verde) e podridão parda (ícone azul). 


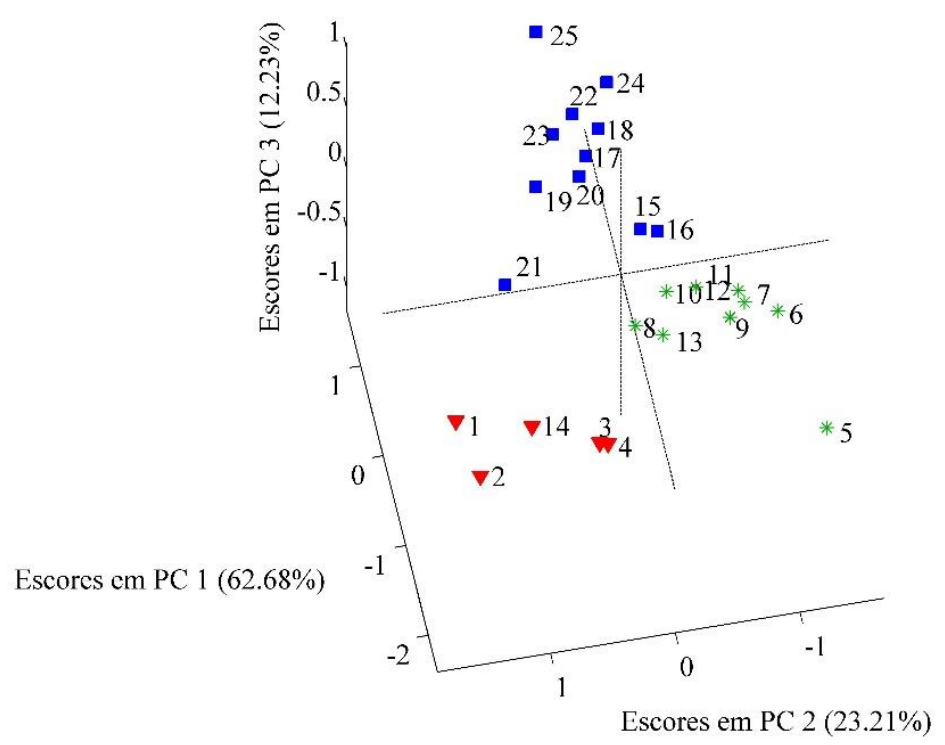

Figura 6.28 Gráfico de escores obtido para a madeira de Eucalyptus saligna após o ataque de Trametes versicolor (2-13) e Gloeophyllum trabeum (14-25).

Observando-se particularmente a Figura 6.29, que apresenta os escores relativos à componente 1, é nítida a distinção entre as amostras testemunhas (1) e as amostras atacadas pelos fungos de podridão branca (2-13) e podridão parda (15-25). O comportamento da fluorescência emitida pelas amostras referentes à primeira semana de ataque de podridão parda (representadas pelo número 14) não é explicado pela primeira componente principal, em função da sua localização errônea próxima às amostras atacadas pelo fungo de podridão branca.

Como a madeira de Eucalyptus saligna foi considerada moderadamente resistente ao ataque de ambos os fungos apodrecedores, uma alteração significativa na fluorescência emitida para total diferenciação entre o ataque dos fungos demorou um pouco mais para ser observada. Apesar disso, o fungo Gloeophyllum trabeum apresentou mecanismo de ataque mais intenso, possibilitando a detecção de ataque mais rapidamente, se comparado ao fungo Trametes versicolor. 


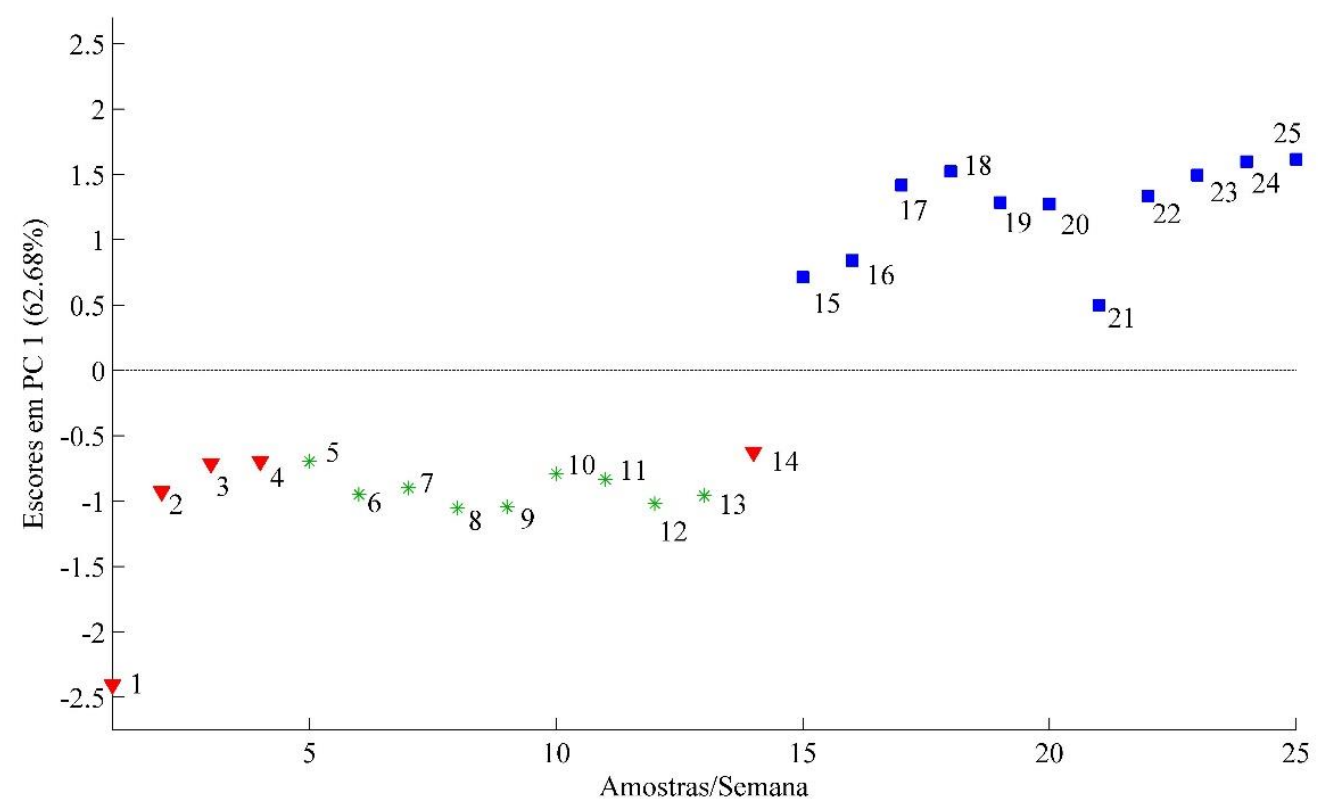

Figura 6.29 Gráfico de escores relativos à componente 1 obtido para a madeira de Eucalyptus saligna após o ataque de Trametes versicolor (2-13) e Gloeophyllum trabeum (14-25).

Para compreender a distribuição semanal das amostras em cada componente principal, é necessário analisar os gráficos de pesos para cada componente, pois estes fornecem a composição das componentes principais em relação à variável fluorescência emitida.

Para as madeiras de marupá e eucalipto, os gráficos de pesos, apresentados nas Figura 6.30 e 6.31, indicaram que, na componente 1, a separação entre as amostras submetidas ao ataque de Gloeophyllum trabeum (escores positivos) e Trametes versicolor (escores negativo) ocorreu por que as amostras que tiveram escores positivos (podridão parda) apresentaram altos valores de intensidade de fluorescência emitida em bandas de comprimento de onda com peso positivo e baixos valores de intensidade em bandas de comprimento de onda com peso negativo, enquanto que as amostras que tiveram escores negativos (podridão branca) apresentaram altos valores de intensidade em bandas de comprimento de onda com peso negativo e baixos valores de intensidade em bandas comprimento de onda com peso positivo. A análise do gráfico de pesos da componente 2 e 3 segue a mesma lógica relatada anteriormente. 

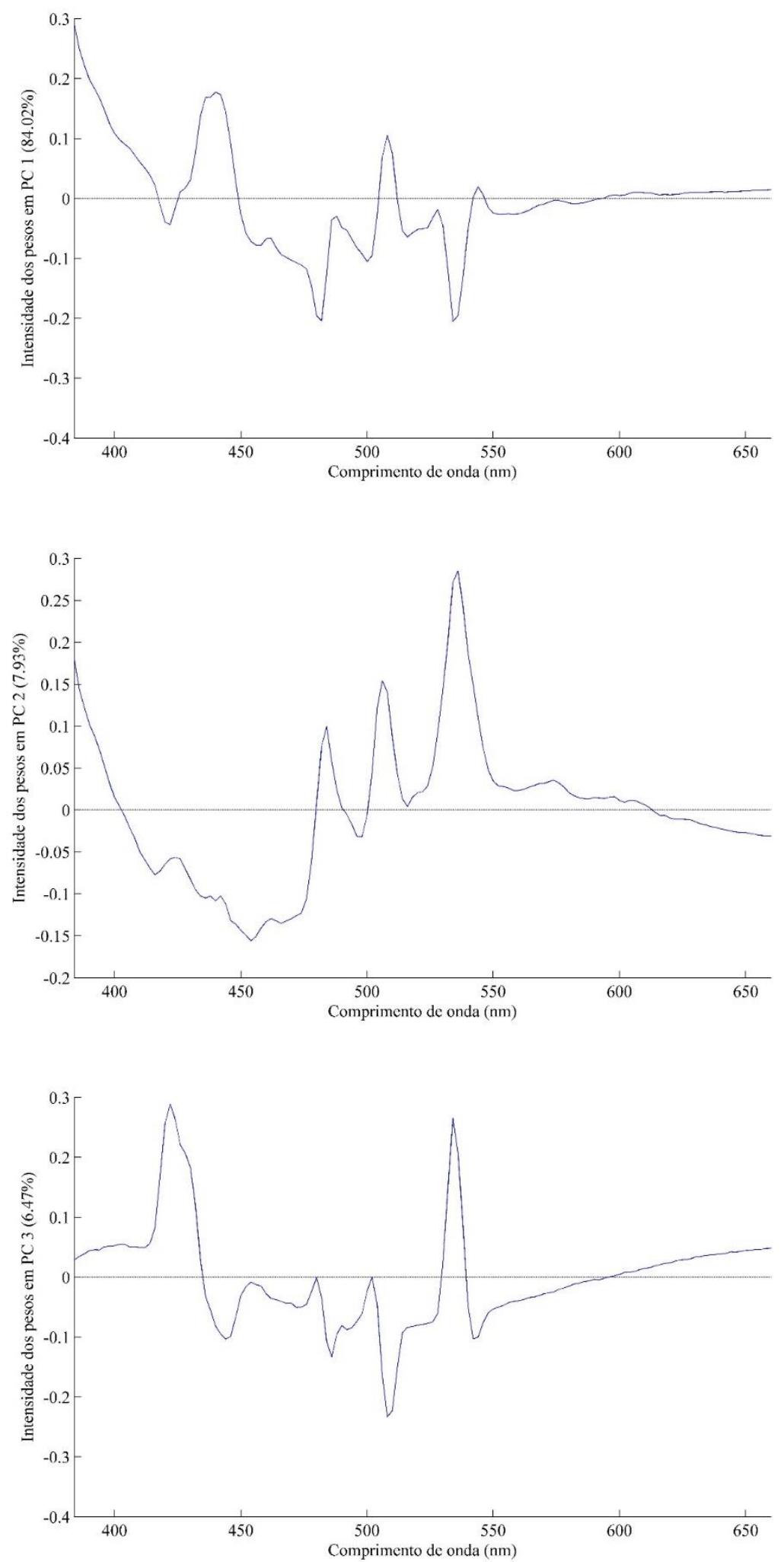

Figura 6.30 Gráfico de pesos das componentes 1, 2 e 3 referentes às amostras de Simarouba amara submetidas aos fungos apodrecedores. 

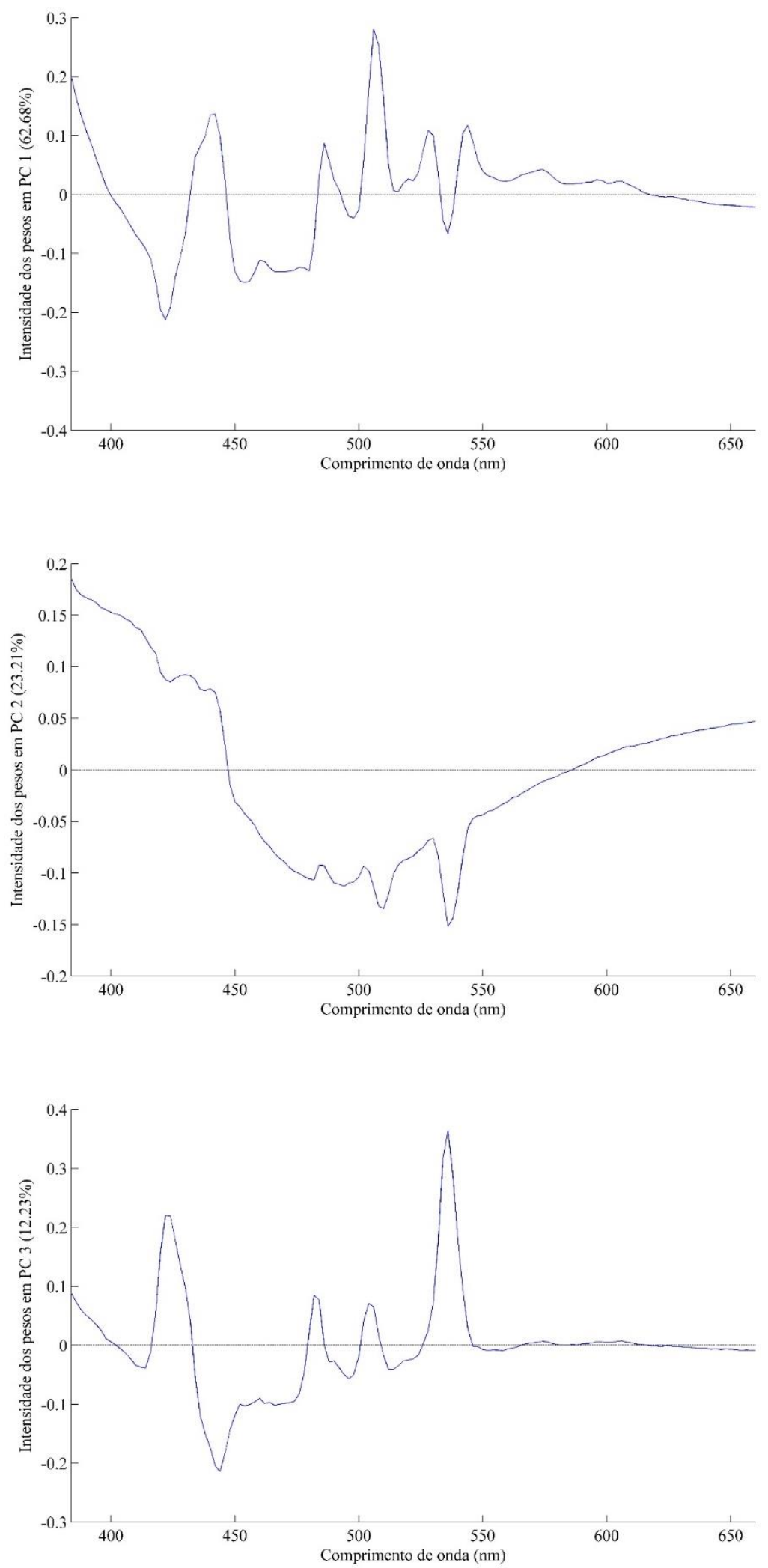

Figura 6.31 Gráfico de pesos das componentes 1, 2 e 3 referentes às amostras de Eucalyptus saligna submetidas aos fungos apodrecedores. 
Em função da melhor distinção entre os fungos de podridão branca e parda ser observada na componente 1, ela foi analisada mais detalhadamente, e escolhidos os principais comprimentos de onda responsáveis pela discriminação, uma vez que os pesos positivos e negativos determinam os escores e distribuição das amostras estudadas. Portanto, para a madeira de Simarouba amara, foram identificados os comprimentos de onda em $440 \mathrm{~nm}$ (maior peso positivo) e $534 \mathrm{~nm}$ (maior peso negativo). Já para a madeira de Eucalyptus saligna, os comprimentos de onda em $422 \mathrm{~nm}$ (maior peso negativo) e 506 (maior peso positivo) foram os selecionados. Os resultados estão apresentados nos Apêndices E e F, e forneceram informações decisivas para a elucidação dos comportamentos dos dois fungos apodrecedores ao atacarem as espécies de madeira.

A madeira sadia (testemunha) de Simarouba amara apresentou uma intensidade de fluorescência emitida, em $440 \mathrm{~nm}$, de 226,18. Ao ser exposta ao fungo Trametes versicolor, passou a emitir, entre a segunda e a sexta semana, sinal de fluorescência sempre em intensidades maiores do que o registrado para a testemunha, oscilando entre 301,30 (semana 2) a 383,01 (semana 6). A partir da sétima semana, o sinal de fluorescência caiu significativamente, atingindo a intensidade de 186,46 na décima segunda semana de teste. Por outro lado, ao ser atacada por Gloeophyllum trabeum, foi registrado um pequeno aumento na fluorescência emitida após uma semana de ataque $(268,69)$, e em seguida, só foram observados valores de intensidade abaixo do registrado para a testemunha, entre 153,47 (semana 2) e 72,38 (semana 12).

Ao analisar o comprimento de onda em 534 nm, a madeira sadia de Simarouba amara emitiu fluorescência de intensidade 169,99 e, após o ataque de Trametes versicolor passou a emitir sinais de fluorescência mais elevados, variando entre 264,23 (semana 2) a 205,59 (semana 12), com exceção da décima primeira semana. Após o ataque de Gloeophyllum trabeum a intensidade de fluorescência emitida reduziu, oscilando entre 138,12 (semana 1) a 40,81 (semana 12).

Para a madeira de Eucalyptus saligna, a intensidade de fluorescência observada antes do ataque de ambos os fungos, no comprimento de onda de $422 \mathrm{~nm}$, foi 287,39. Logo após ser exposta ao fungo Trametes versicolor, a intensidade de emissão foi registrada em valores mais altos, variando entre 354,70 (semana 1) a 298,70 (semana 5). Após este período, sofreu pequenos decréscimos, porém, ao final de 12 semanas foi registrada em 297,51. Ao ser atacada por Gloeophyllum trabeum, a madeira de eucalipto apresentou na primeira semana 
um acréscimo na intensidade $(294,63)$, porém no decorrer do experimento as intensidades registradas estavam sempre abaixo do valor observado para as amostras testemunhas, variando entre 125,17 (semana 2) a 58,04 (semana 12).

Ao observar o pico de $506 \mathrm{~nm}$, a madeira sadia apresentou intensidade de fluorescência de 173,59. Após o ataque de Trametes versicolor, as intensidades obtidas foram superiores à registrada para as amostras testemunhas, oscilando entre 312,82 (semana 1) a 282,03 (semana 12). Os valores de intensidade de fluorescência emitida obtidos após a exposição da madeira de eucalipto ao fungo Gloeophyllum trabeum foram inferiores à intensidade registrada para a madeira sadia, com exceção das amostras da semana $1(292,06)$, variando entre 163,09 (semana 2) a 75,04 (semana 12).

Os testes de médias também indicaram que, ao longo do período de execução do experimento, houveram muitas igualdades estatísticas entre as intensidades registradas. $\mathrm{Ou}$ seja, de uma semana para outra, a fluorescência emitida não apresentava um valor significativamente diferente, tornando as emissões semanais mais semelhantes. Isto pode ser observado nas proximidades e até sobreposições entre os espectros semanais, apresentados nas Figuras 6.11 a 6.14 e nos gráficos de escores (Figuras 6.17 e 6.18).

Ainda assim foi possível comprovar, por meio da análise de fluorescência molecular, os diferentes mecanismos enzimáticos dos fungos de podridão branca (Trametes versicolor) e podridão parda (Gloeophyllum trabeum) ao atacarem as madeiras de marupá e eucalipto durante um período de 12 semanas.

As Figura 6.32 e 6.33 apresentam as médias de intensidade de fluorescência emitida pelas madeiras de Simarouba amara e Eucalyptus saligna antes e após 12 semanas de ataque dos fungos apodrecedores.

Um ponto a ser ressaltado é que a fluorescência da madeira está relacionada à presença de compostos fluoróforos, que fazem parte da composição dos extrativos, de forma que uma madeira com maior quantidade de extrativos apresenta uma maior fluorescência molecular. Verificou-se então que, para a madeira de eucalipto sadia, que possui maior quantidade de extrativos $(7,87 \%)$ em relação à madeira de marupá $(2,49 \%)$, a fluorescência média emitida para todos os comprimentos de onda entre $384 \mathrm{~nm}$ e $660 \mathrm{~nm}$ também foi observada em maior intensidade $(100,90)$ se comparada à madeira de marupá $(93,13)$. 


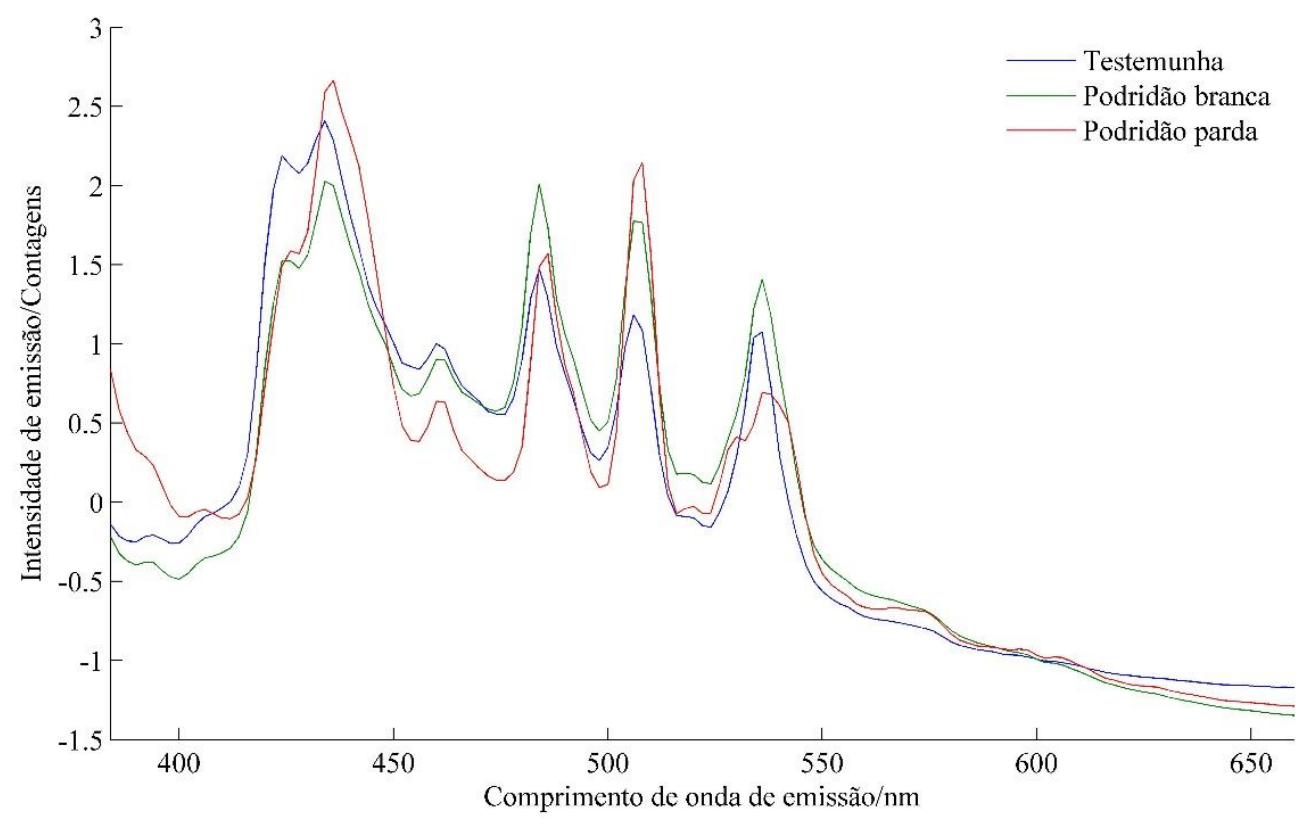

Figura 6.32 Espectros de emissão de fluorescência obtidos por excitação em $370 \mathrm{~nm}$ para a madeira de Simarouba amara sadia e após 12 semanas de ataque dos fungos Trametes versicolor (podridão branca) e Gloephyllum trabeum (podridão parda).

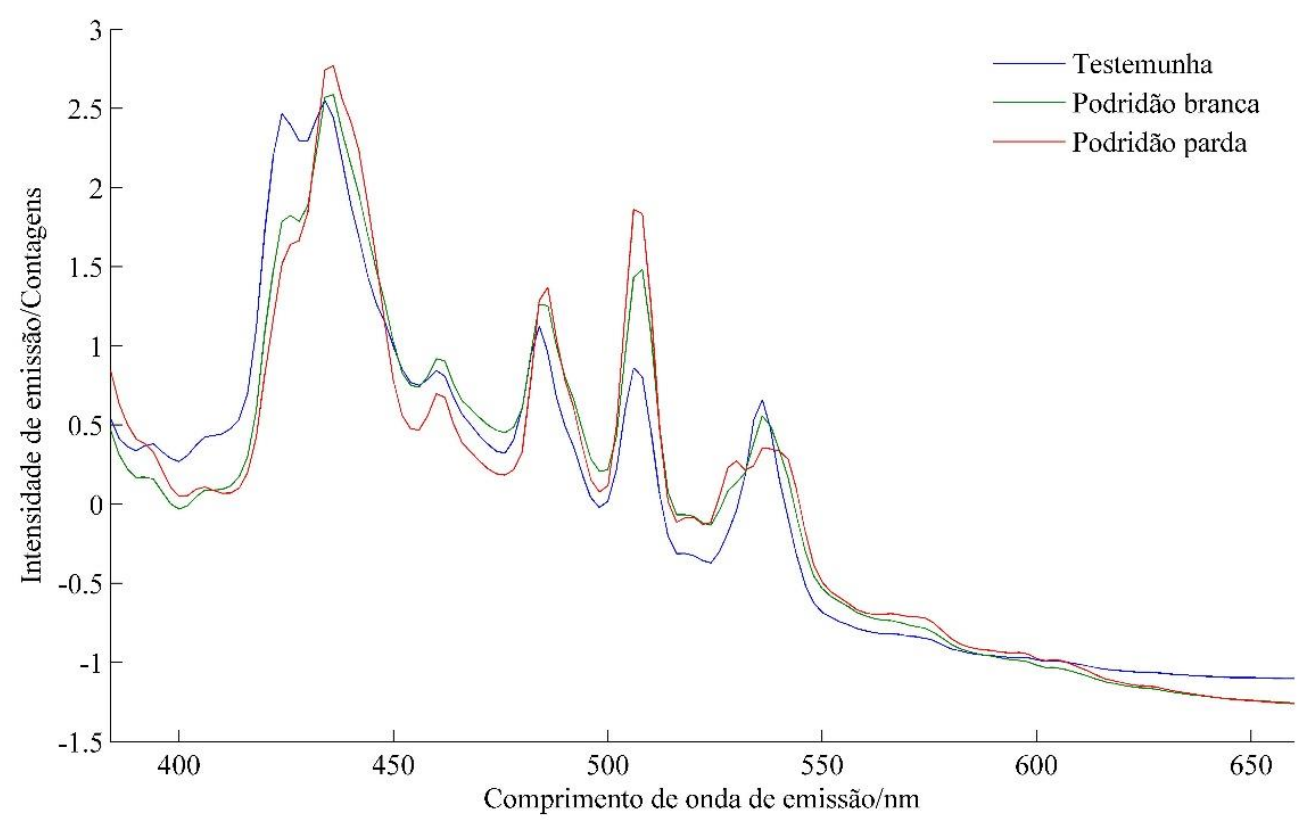

Figura 6.33 Espectros de emissão de fluorescência obtidos por excitação em $370 \mathrm{~nm}$ para a madeira de Eucalyptus saligna sadia e após 12 semanas de ataque dos fungos Trametes versicolor (podridão branca) e Gloephyllum trabeum (podridão parda). 
As Tabelas 6.12 e 6.13 apresentam as correlações obtidas entre as intensidades de emissão de fluorescência, o período de ataque e a perda de massa sofrida, para as duas espécies de madeira.

Tabela 6.12 Correlação entre a fluorescência emitida, o período de exposição aos fungos e a perda de massa da madeira de Simarouba amara.

\begin{tabular}{lcccc}
\hline \multirow{2}{*}{ Simarouba amara } & \multicolumn{2}{c}{$440 \mathrm{~nm}$} & \multicolumn{2}{c}{$534 \mathrm{~nm}$} \\
\cline { 2 - 5 } & TV & GT & TV & GT \\
\hline Período (Semanas) & $-0,46^{\mathrm{NS}}$ & $-0,79^{* *}$ & $-0,27^{\mathrm{NS}}$ & $-0,75^{* *}$ \\
\hline Perda de massa (\%) & $-0,43^{\mathrm{NS}}$ & $-0,86^{* *}$ & $-0,25^{\mathrm{NS}}$ & $-0,82^{* *}$
\end{tabular}

Em que: TV $=$ Trametes versicolor $; \mathrm{GT}=$ Gloeophyllum trabeum; $* *=$ significativo a $1 \%$; $*=$ significativo a $5 \% ;{ }^{\mathrm{NS}}=$ não significativo.

Tabela 6.13 Correlação entre a fluorescência emitida, o período de exposição aos fungos e a perda de massa da madeira de Eucalyptus saligna.

\begin{tabular}{lcccc}
\hline \multirow{2}{*}{ Eucalyptus saligna } & \multicolumn{2}{c}{$422 \mathrm{~nm}$} & \multicolumn{2}{c}{$506 \mathrm{~nm}$} \\
\cline { 2 - 5 } & TV & GT & TV & GT \\
\hline Período (Semanas) & $-0,69 * *$ & $-0,73 * *$ & $-0,25^{\mathrm{NS}}$ & $-0,72 * *$ \\
\hline Perda de massa (\%) & $-0,64 *$ & $-0,74 * *$ & $-0,23^{\mathrm{NS}}$ & $-0,75^{* *}$ \\
\hline
\end{tabular}

Em que: $\mathrm{TV}=$ Trametes versicolor; $\mathrm{GT}=$ Gloeophyllum trabeum; $* *=$ significativo a $1 \%$; $*=$ significativo a $5 \% ;{ }^{\mathrm{NS}}=$ não significativo.

Verificou-se que nos quatro comprimentos de onda analisados (440 nm e $534 \mathrm{~nm}-$ Simarouba amara e $422 \mathrm{~nm}$ e $506 \mathrm{~nm}$ - Eucalyptus saligna), a fluorescência após o ataque de Gloeophyllum trabeum está correlacionada negativa e significativamente com o período de exposição ao fungo e com a perda de massa decorrente do seu ataque. Isso implica que, ao aumentar o período de teste e, consequentemente, a perda de massa, o sinal de fluorescência emitida passa a ser reduzido consideravelmente.

Entretanto, após o ataque de Trametes versicolor só foram observadas correlações significativas entre a intensidade de fluorescência emitida em $422 \mathrm{~nm}$, o período e a perda de massa sofrida após o ataque à madeira de Eucalyptus saligna.

Isto pode ser explicado pela intensidade do ataque de podridão parda, que proporciona uma deterioração mais severa da madeira. 


\section{CONCLUSÕES E RECOMENDAÇÕES}

Após 12 semanas de exposição aos fungos apodrecedores, a madeira de Simarouba amara foi considerada moderadamente resistente ao Trametes versicolor e não resistente ao Gloeophyllum trabeum e a de Eucalyptus saligna moderadamente resistente a ambos os fungos apodrecedores.

O ataque do fungo Gloeophyllum trabeum foi mais severo nas duas espécies de madeira, proporcionando maiores alterações nas suas propriedades físicas e químicas.

A madeira de Simarouba amara apresentou-se mais escura (redução do L $^{*}$ ) e a de Eucalyptus saligna mais clara (aumento do L*), após o ataque do fungo Trametes versicolor. A maior alteração ocorreu na coordenada b*, resultando no amarelecimento das amostras de ambas as espécies de madeiras.

Ambas as espécies de madeiras apresentaram-se mais escuras e avermelhadas (redução drástica do L*), após o ataque de Gloeophyllum trabeum, com um aumento significativo da coordenada $a^{*}$.

A colorimetria mostrou ser uma técnica bastante eficaz, auxiliando na compreensão dos diferentes mecanismos de ação dos fungos de podridão branca e parda, possibilitando também a diferenciação entre eles.

A espectroscopia no infravermelho médio (DRIFT) possibilitou o monitoramento da intensidade das bandas referentes à lignina e aos polissacarídeos de Simarouba amara e Eucalyptus saligna, permitindo distinguir os mecanismos de ação dos fungos Trametes versicolor e Gloeophyllum trabeum durante e após o ataque a ambas as espécies de madeiras.

Foi observado um aumento de $80 \%$ na intensidade da banda de $1740 \mathrm{~cm}^{-1}$ (hemiceluloses) e uma redução de $70 \%$ na banda de $899 \mathrm{~cm}^{-1}$ (celulose) após o ataque do fungo Gloeophyllum trabeum na madeira de Simarouba amara.

A celulose em $899 \mathrm{~cm}^{-1}$ foi o composto mais metabolizado durante o ataque de Gloeophyllum trabeum às madeiras de Simarouba amara e Eucalyptus saligna.

A técnica de fluorescência molecular permitiu detectar de forma precoce (até a quarta semana) o ataque dos fungos Trametes versicolor e Gloeophyllum trabeum, e também discriminá-los segundo a intensidade de fluorescência emitida pela madeira atacada. 
A fluorescência molecular mostrou resultado consistente com o das outras técnicas, sendo capaz de constatar que o fungo Gloeophyllum trabeum apresentou um mecanismo de metabolização enzimática mais intenso do que o Trametes versicolor.

Foi observada uma relação direta entre a fluorescência emitida e a presença de extrativos ou compostos fluoróforos na madeira, onde quanto maior a presença destes compostos, maior foi a fluorescência molecular emitida pela madeira.

Recomenda-se a realização de novos ensaios empregando a técnica de fluorescência molecular, com outras espécies de madeiras, avaliando outros comprimentos de onda ou faixas de comprimentos de onda, além da diferenciação entre amostras de cerne e alburno, para comprovar a eficácia desta técnica na detecção do ataque de fungos apodrecedores. 


\section{REFERÊNCIAS BIBLIOGRÁFICAS}

ALMEIDA, N.A.; MENDES, L.M.; OKINO, E.Y.A.; GARLET, A.; MORI, F.A.; MENDES, R.F. Biodeterioração de produtos à base da madeira de cedro australiano (Toona ciliata M. Roem. var. australis). Cerne, v.18, n.1, p.17-26, 2012.

ALZATE, A. B. A. Caracterização da madeira de árvores de clones de Eucalyptus grandis, E. saligna e E. grandis x urophylla. 2004, 133p. Tese de doutorado - Escola Superior de Agricultura Luiz de Queiroz, Piracicaba.

AMERICAN SOCIETY FOR TESTING AND MATERIALS (ASTM). ASTM D 2017: Standard method for accelerated laboratory test of natural decay resistance for woods. Philadelphia, 2005.

AMERICAN SOCIETY FOR TESTING AND MATERIALS (ASTM). ASTM D 2244-09a: Standard practice for calculation of color tolerances and color differences from instrumentally measured color coordinates. Philadelphia, 2009.

ARANTES, V.; MILAGRES, A.M.F. Relevância de compostos de baixa massa molar produzidos por fungos e envolvidos na biodegradação da madeira. Química Nova, v.32, n.6, p.1586-1595, 2009.

ASSOCIAÇÃO BRASILEIRA DE NORMAS TÉCNICAS (ABNT). NBR 11941: Determinação da densidade básica. Rio de Janeiro: ABNT, 2003a.

AUTRAN, C.S.; GONÇALEZ, J.C. Caracterização colorimétrica das madeiras de muirapiranga (Brosimum rubescens Taub.) e de seringueira (Hevea brasiliensis, clone Tjir 16 Müll Arg.) visando à utilização em interiores. Ciência Florestal, v.16, n.4, p. 445-451, 2006.

AVELLA, T.; DECHAMPS, R.; BASTIN, M. Fluorescence study of 10,610 wood species from the Tervuren (Tw) collection, Belgium. IAWA Bulletin n.s., v.9, n.4, p. 346$352,1988$.

BARKER, B.; OWEN, N.L. Identifying softwoods and hardwoods by infrared spectroscopy. Journal of Chemical Education, v.76, n.12, p.1706-1709, 1999. 
BATISTA, D. C.; KLITZKE, R, J.; SANTOS, C. V. T. Densidade básica e retratibilidade da madeira de clones de três espécies de Eucalyptus. Ciência Florestal, v.20, n.4, p. 665-674, 2010.

BORGES, L. M.; QUIRINO, W. F. Higroscopicidade da madeira de Pinus caribaea var. hondurensis tratado termicamente. Revista Biomassa \& Energia, v.1 n.2, p.173-182, 2004.

BOTElHO, G. M. L.; SANTANA, M. A. E.; ALVES, M. V. S. Caracterização química, durabilidade natural e tratabilidade da madeira de seis espécies de eucaliptos plantadas no Distrito Federal. Revista Árvore, v.24, n.1, p.115-121, 2000.

BUCUR, V. Acoustics of wood. New York: CRC Press, 1995.

BURGER, L. M.; RICHTER, H. G. Anatomia da madeira. São Paulo: Ed. Nobel, 154p. 1991.

CAMARGOS, J. A. A.; GONÇALEZ, J. C. A colorimetria aplicada como instrumento na elaboração de uma tabela de cores de madeira. Brasil Florestal, n.71, p.3041, 2001.

CAMARGOS; J. A. A. Colorimetria quantitativa aplicada na elaboração de uma tabela de cores para madeiras tropicais. 1999. 99f. Dissertação de mestrado Universidade de Brasília, Brasília.

CARNEIRO, J. S.; EMMERT, L.; STERNADT, G. H.; MENDES, J. C.; ALMEIDA, G. F. Decay susceptibility of Amazon wood species from Brazil against white rot and brown rot decay fungi. Holzforschung, v.63, p.767-772, 2009.

CARNEIRO, M. E.; MAGALHÃES, W. L. E.; SILVANA, N.; MUÑIZ, G. I. Classificação de lâminas de madeira de Pinus spp. contaminadas por fungos manchadores. Revista Árvore, v.37, n.2, p.369-375, 2013.

CARREIRA, M. R.; CHEUNG, A. B.; OLIVEIRA, F. G. R.; DIAS, A. A.; CALIL JÚNIOR, C.; SALES, A.; CANDIAN, M. Classificação de peças estruturais de Pinus sp. por ultrassom. In: Congresso Brasileiro de Engenharia e Ciência dos Materiais, 17., 2006, Foz do Iguaçu. Anais... Foz do Iguaçu: 2006. p.8316-8328.

CHEN, J.; LEBOEUF, E. J.; DAI, S.; GU, B. Fluorescence spectroscopic of natural organic matter fractions. Chemosphere. v.50, p.639-647, 2003. 
COLODETTE, J. L. Wood chemistry course. Viçosa: UFV, 2005. 230 p.

COLOM, X.; CARRILLO, F.; NOGUÉS, F.; GARRIGA, P. Structural analysis of photodegraded wood by means of FTIR spectroscopy. Polymer Degradation and Stability, v. 80, p. 543-549, 2003.

COMMONWEALTH SCIENTIFIC AND INDUSTRIAL RESEARCH ORGANISATION. Revised CSIRO natural durability classification in ground durability ratings for mature outer heartwood. Clayton: 1997.

COSTA, A. F.; VALE, A. T.; GONÇALEZ, J. C.; SOUZA, F. D. M. Durabilidade de madeiras tratadas e não tratadas em campo de apodrecimento. Floresta e Ambiente, v.12, n.1, p.7-14, 2005.

COSTA, M. A. Avaliação de metodologias alternativas para caracterização do ataque de fungos apodrecedores de madeiras. 2009. 83f. Dissertação de mestrado Universidade de Brasília. Brasília.

CRUZ, M. L. R.; FINGER, Z.; LOGSDON, N. B. Marupá: descrição dendrológica e caracterização física. In: Encontro Brasileiro em Madeiras e em Estruturas de Madeira, 10. 2006, São Paulo. Anais...São Paulo: 2006.

CRUZ, M. L. R.; RODRIGUES JÚNIOR, M. S.; FINGER, Z. Marupá: caracterização mínima de resistência e simplificada da rigidez. In: Encontro Brasileiro em Madeiras e em Estruturas de Madeira, 10. 2006, São Paulo. Anais...São Paulo: 2006.

DALTON, F. K. Woods that shine in the dark: Interesting reaction of certain woods during exposure to invisible or black light. Canadian Woodworker and Furniture Manufacturer, 1934.

DENCE, C.W.; LIN, S.Y. Methods in lignin chemistry. New York: Springer Verlang, 1992. 578p.

DUARTE, V. C. S.; OLIVEIRA, T. L. C.; CORADIN, V. T. R.; CAMARGOS, J. A. A.; GOnTIJO, A. B.; MARQUES, L. F.; PASTORE, T. C. M. Determinação da fluorescência na madeira de mogno e similares. Resumos da $37^{a}$ Reunião Anual da Sociedade Brasileira de Química, Natal, 2014.

DYER, S. T. Wood fluorescence of indigenous South African trees. IAWA Bulletin n.s., v. 9, n.1, p.75-87, 1988. 
EATON, R.A.; HALE, M.D.C. Wood: decay, pests and protection. Londres: Chapman e Hall, 1993. 546p.

ERIKSON, R. G.; GORMAN, T. M.; GREEN, D. W.; GRAHAM, D. Mechanical grading of lumber sawn from small-diameter lodgepole pine, ponderosa pine and grand fir trees from northern Idaho. Forest products journal, v.50, n.7/8, p.59-65, 2000.

FACKLER, K.; SCHWANNINGER, M.; GRADINGER, C.; HINTERSTOISSER, B.; MESSNER, K. Qualitative and quantitative changes of beech wood degraded by woodrotting basidiomycetes monitored by Fourier transform infrared spectroscopic methods and multivariate data analysis. FEMS Microbiol Lett, v. 271, n.2, p. 162-169, 2007.

FAIX, O.; BREMER, J.; SCHMIDT, O.; STEVANOVIC, T. Monitoring of chemical changes in white-rot degraded beech wood by pyrolysis-gas chromatography and Fouriertransform infrared spectroscopy. Journal of Analytical and Applied Pyrolysis, v. 21, p. 147-162, 1991.

FENGEL, D.; WEGENER, G. Wood: Chemistry, Ultrastructure, Reactions. Berlin, New York: Ed. Walter de Gruyter, 1989, 613p.

FENGEL, D.; WEGENER, G. Wood: Chemistry, Ultrastructure, Reactions. Berlin, New York: Ed. Walter de Gruyter, 1984. 613p.

FERRAZ, A.; BAEZA, J.; RODRIGUEZ, J.; FREER, J. Estimating the chemical composition of biodegraded pine and eucalyptus wood by DRIFT spectroscopy and multivariate analysis. Bioresource Technology, v. 74, p. 201-212, 2000.

FREITAS, A. C. S.; COSTA, A. F.; GARLET, A. Resistência natural e colorimetria de Marupá (Simarouba amara) e Eucalyptus grandis submetidas ao ataque de fungos apodrecedores. In: Reunião Anual da Sociedade Brasileira para o Progresso da Ciência, 64., 2012, São Luís. Anais..., São Luís: 2012.

GONÇALEZ, J. C.; BREDA, L. C. S.; BARROS, J. F. M.; MACEDO, D. G.; JANIN, G.; COSTA, A. F.; VALE, A. T. Características tecnológicas das madeiras de Eucalyptus grandis W. Hill ex Maiden e Eucalyptus cloeziana F. Muell visando ao seu aproveitamento na indústria moveleira. Ciência Florestal, v.16, n.3, p.329-341, 2006.

GONÇALEZ, J.C. Caracterization technologique de quatre espèces peu connues de la Forêt Amazonienne: anatomie, chimie, couleur, proprietés physiques et 
mécaniques. 1993. 444f. Thèse (Doctorat Technologie du Bois) - École Nationale du Gêne Rural des Eaux et des Forêts, Nancy.

GONÇALEZ, J.C.; JANIN, G.; SANTORO, A.C.S.; COSTA, A.F.; VALlE, A.T. Colorimetria quantitativa: Uma técnica objetiva de determinar a cor da madeira. Brasil Florestal, n.72, p.47-58, 2001.

GONÇALVES, J.C.; MACEDO, D.G. Colorimetria aplicada à madeira de eucalipto. In: SILVA, J.C.; GOMES, J.M. (Eds.) II Seminário de Produtos Sólidos de Madeira de Eucalipto. Belo Horizonte. p.81-95, 2003.

GOUVEIA, F. N. Aplicação de tratamentos térmicos para estabilização colorimétrica de madeiras tropicais. Tese de doutorado. 2008. 143f. Universidade de Brasília, Brasília.

GRIEBELER, C. G. O. Colorimetria da madeira de Eucalyptus grandis W. Hill ex Maiden modificada termicamente. 2013. 69f. Dissertação de mestrado. Universidade Federal do Paraná, Curitiba.

GUIMARÃES, I. L.; GUIMARÃES JUNIOR, J. B.; LISBOA, F. J. N.; ANDRADE, C. R.; SIQUEIRA, H. F. Caracterização química e física da madeira de procedências de Eucalyptus. Enciclopédia Biosfera, Centro Científico Conhecer, v.9, n.17, p. 636-645, 2013.

HARRIS, D. C. Análise Química Quantitativa. 6ª Edição. Rio de Janeiro: LTC, 2005.

HITTLER, C. R.; FREESE, F.; SMITH, D. M. Relationships in black walnut heartwood between color and other physical and anatomical characteristics. Wood and Fiber Science, v. 4, n. 1, p. 38-42, 1972.

HOLDSCHIP, R. A influência dos sistemas de gerenciamento de cores em provas digitais. 2008. 123f. Dissertação de mestrado - Universidade Estadual Paulista, Bauru.

HOller, F. J.; SKOOG, D. A.; CROUCH, S. R. Princípios de Análise Instrumental. $6^{\text {a }}$ edição. Porto Alegre: Bookman, 2009.

HON, N. S. Formation of free radicals in photoirradiated cellulose - VI: effect of lignin. Journal of Science Polymer Chemistry, n. 12, p. 2641-2652, 1975. 
Instituto de Pesquisas e Estudos Florestais - IPEF. Disponível em: http://www.ipef.br/identificacao/eucalyptus/\#saligna. Acessado em: 16/01/2016.

Instituto de Pesquisas Tecnológicas - IPT. Disponível em: http://www.ipt.br/informacoes_madeiras/60.htm. Acessado em: 16/01/2016.

INSTITUTO DE PESQUISAS TECNOLÓGICAS DO ESTADO DE SÃO PAULO - IPT. Sistema de Informações de Madeiras Brasileiras. São Paulo: IPT, 1989b. 291p. (Relatório No 27 078).

JANIN, G. La couleur du bois, um facteur clé de qualité. Mesures, n. 17, pp. 61-65, 1986.

JANKOWSKY, I. P.; CHIMELO, J. P.; CAVALCANTE, A. A.; GALINA, I. C.; NAGAMURA, J. C. S. Madeiras brasileiras. Caxias do Sul: Spectrum, 1990, 172p.

JAYNE, B. A. Vibrational properties of wood as indices of wood quality. Forest Products Journal, v. 9, n. 11, p. 413-416, 1959.

JESUS, M. A.; MORAIS, J. W.; ABREU, R. L. S.; CARDIAS, M. F. C. Durabilidade natural de 46 espécies de madeira amazônica em contato com o solo em ambiente florestal. Scientia Forestalis, n.54, p.81-92, 1998.

KELLEY, S. S.; JELLISON, J.; GOODELL, B. Use of NIR and pyrolysis - MBMS coupled with multivariate analysis for detecting the chemical changes associated with brown-rot biodegradation of spruce wood. FEMS Microbiology Letters, v.209, n.1, p.107$111,2002$.

KIRK, T. K.; CULLEN, D.; Environmentally friendly technologies for the pulp and paper industry. New York: John Wiley and Sons, 1998.

KLOCK, U.; MUÑIZ, G.I.B.; HERNANDEZ, J.A.; ANDRADE, A.S. Química da madeira. $3^{\text {a }}$ edição. Curitiba: FUPEF, 2005. 86p.

KOKUTZE, A.D.; STOKES, A.; BAILLÈRES, H.; KOKOU, K.; BAUDASSE, C. Decay resistance of Togolese teak (Tectona grandis L.f) heartwood and relationship with color. Trees, v.20, p.219-223, 2006. 
KOKUTZE, A.D.; STOKES, A.; BAILLÈRES, H.; KOKOU, K.; BAUDASSE, C. Decay resistance of Togolese teak (Tectona grandis L.f) heartwood and relationship with colour. Trees, v.20, p.219-223, 2006.

KRISHNA, S.; CHOWDHURY, K. A. Fluorescence of wood under ultra-violet light. Indian Forester, v.61, n.4, 1935.

LEPAGE, E.S. Química da madeira. In: LEPAGE, E.S. Manual de preservação de madeiras. São Paulo: IPT, 1986. v.1, p.69-97.

LIMA, D. U. Interação molecular entre celulose e hemiceluloses e suas implicações biológicas e tecnológicas. 2002. 110f. Tese de doutorado - Universidade Estadual de Campinas, São Paulo.

LONGUE JÚNIOR, D.; COLODETTE, J. L. Remoção de hemiceluloses da madeira por tratamento de auto-hidrólise. Ciência Florestal, v.21, n.3, p.541-550, 2011.

LOUREIRO, A.A.; SILVA, M.F.; ALENCAR, J.C. 1979. Essências madeireiras da Amazônia. Instituto Nacional de Pesquisas da Amazônia, INPA/SUFRAMA-MA. Manaus, AM, v.I. 245 pp.

MADY, F.T.M. Conhecendo a madeira: informações sobre 90 espécies comerciais. Manaus: SEBRAE-AM, 2000. 212p.

MARCÓ, M. Subprograma eucaliptos en Región Mesopotámica. In: NORVERTO, C. A. (Ed.). Mejores árboles para más forestadores: el programa de producción de material de propagación mejorado y el proyecto forestal de desarrollo. Buenos Aires: Secretaría de Agricultura, Ganadería, Pesca y Alimentos, 2005. p. 57-71.

MARCONDES, E. Resistência natural da madeira de duas espécies amazônicas em ensaios de campo. 2011. 34f. Trabalho de conclusão de curso - Universidade Federal de Mato Grosso, Sinop, 2011.

MARQUES, M. H. B. (Coord.). Madeiras da Amazônia: características e utilização. Brasília: Instituto Brasileiro do Meio Ambiente e dos Recursos Naturais Renováveis, 1997. 141 p.

MARTINS, S. A.; SANTOS, C. M. T.; GONÇALEZ, J. C.; CAMARGOS, J. A. A. Envelhecimento artificial acelerado por radiação ultravioleta de madeiras de Eucalyptus benthamii e Pinus caribaea var. hondurensis. Floresta, v.41, n.1, p.87-96, 2011. 
MENDES, A. S.; ALVES, M. V. S. A degradação da madeira e sua preservação. Brasília, IBDF/DPq-LPF, 1988.

MENDHAM, J.; DENNEY, E. C.; BARNES, J. D.; THOMAS, M. J. K. Análise Química Quantitativa. 6a edição. Rio de Janeiro: Ed. LTC, 2002.

MILLER, R. B. Fluorescent woods of the world. In: A guide to more useful woods of the world. Madison: Ed. International Wood Collectors Society, 2007.

MOORE, A.K.; OWEN, N.L. Infrared spectroscopic studies of solid wood. Applied Spectroscopy Reviews, v.36, p.65-68, 2001.

MORA, A. L.; GARCIA, C. H. A cultura do eucalipto no Brasil. São Paulo: SBS, 2000. 112p.

MORAIS, F. M.; COSTA, A. F. Alteração da cor aparente de madeiras submetidas ao ataque de fungos apodrecedores. Revista Brasileira de Ciências Agrárias, v.2, n.1 p.4450, 2007.

MORESCHI, J. C. Biodegradação e preservação da madeira: Biodegradação da madeira. Departamento de Engenharia e Tecnologia Florestal, v. 1, n.4, 2013.

MORI, C.L.S. O.; LIMA, J.T.; MORI, F. A.; TRUGILHO, P.F.; GONÇALEZ, J.C.; Caracterização da cor da madeira de clones de híbridos de Eucalyptus spp. Revista Cerne, v. 11, n. 2, p.137-146, 2005.

MORI, C.L.S.O.; LIMA, J.T.; MORI, F.A.; TRUGILHO, P.F.; GONÇALEZ, J.C.; OLIVEIRA, A.C. Colorimetria aplicada à determinação da cor da madeira de Eucalyptus spp. In: Encontro Brasileiro em Madeiras e em Estruturas de Madeira, 9, 2004, Cuiabá. Anais... Mato Grosso: SECOM, 2004. CD-ROM.

MOURA, N. N. Análise exploratória de espécies de madeiras tropicais por medidas de fluorescência e resolução de curvas multivariadas. 2013. 101f. Dissertação de mestrado - Universidade de Brasília, Brasília.

MOYA, R.; FALLAS, R. S.; BONILLA, P. J.; TENORIO, C. Relationship between wood color parameters measured by the CIELab system and extractive and phenol content in Acacia mangium and Vochysia guatemalensis from fast-growth plantations. Molecules, v. 17, p. 3639-3652, 2012. 
MOYA, R.; MARÍN, J.D. 2011. Grouping of Tectona grandis (L.f.) clones using wood color and stiffness. New Forests, 42: 329-345.

MUYSKENS, M. The fluorescence of Lignum nephriticum: a flash back to the past, and a simple demonstration of natural substance fluorescence. Journal of Chemical Education, Washington, 2006.

NISHINO Y.; JANIN G.; YAMUDA Y.; KITANO D. 2000. Relations between colorimetric values and densities of sapwood. Journal of Wood Science, 46: 267-272.

OKINO, E. Y. A.; PASTORE, T. C. M.; CAMARGOS, J. A. A.; CORADIN, V. T. R.; TEIXEIRA, D. E.; SANTANA, M. A. E.; FAGG, C. W. Accelerated laboratory test of three Amazonian wood species called tauari, exposed to white- and brown-rot fungi and color response according to CIE L* A* B* system. Ciência Florestal, v. 25, n. 3, p. 581$593,2015$.

OLIVEIRA, A. G.; CARVALHO, R. P.; WALDENMAIER, H. E.; STEVANI, C. V. Bioluminescência e fungos: distribuição, função e mecanismo de emissão de luz. Química Nova, São Paulo, v.36, n.2, 314-319, 2013.

OLIVEIRA, A.M.F.; LELIS, A.T.; LEPAGE, E.S.; LOPEZ, G.A.C.; OLIVEIRA, L.C.S.; CAÑEDO, M.D.; MILANO, S. Agentes destruidores da madeira. In: LEPAGE, E.S. Manual de preservação de madeiras. São Paulo: IPT, 1986. v.1, p. 99-278.

OLIVEIRA, E. M.; BRAGA, J. W. B.; COSTA, A. F. Discriminação de madeiras similares por fluorescência molecular e mínimos quadrados parciais. Química Nova, 2015. doi: 10.5935/0100-4042.20150127. Disponível em: http://quimicanova.sbq.org.br/imagebank/pdf/AR20150302.pdf

OLIVEIRA, J. T. S.; SOUZA, L. C.; DELLA LUCIA, R. M.; SOUZA JÚNIOR, W. P. Influência dos extrativos na resistência ao apodrecimento de seis espécies de madeira. Revista Árvore, v.29, n.5, 2005.

OLIVEIRA, J. T.; TOMASELLO, M.; SILVA, J. C. Resistência natural da madeira de sete espécies de eucalipto ao apodrecimento. Revista Árvore, v.29, n.6, p.993-998, 2005.

PACE, J. H. C.; DIAS JÚNIOR, A. F.; CARVALHO, A. M.; LATORRACA, J. V. F.; SANTOS, P. V. Efeito do envelhecimento acelerado em duas espécies de folhosas na 
PAES, J. B. Resistência natural da madeira de Corymbia maculata (Hook.) K. D. Hill e L.A.S. Johnson a fungos e cupins xilófagos, em condições de laboratório. Revista Árvore, v. 26, n. 6, p. 761-767, 2002.

PAES, J. B.; MORAIS, V. M.; LIMA, C. R. Resistência natural de nove espécies de madeiras do semi-árido brasileiro a fungos xilófagos em condições de laboratório. Revista Árvore, v.28, n.2, p.275-282, 2004.

PALA, H. Constituição e mecanismos de degradação biológica de um material orgânico: a madeira. Construção Magazine, n.20, p.54-62, 2007.

PANDEY, K. K.; NAGVENI, H. C.; Rapid characterization of brown and white rot degraded chir pine and rubberwood by FTIR spectroscopy. Holz Roh Werkst, v. 65, p. 477 $481,2007$.

PANDEY, K. K.; PITMAN, A. J. FTIR studies of the changes in wood chemistry following decay by brown-rot and white-rot fungi. International Biodeterioration and Biodegradation, v. 52, p. 151-160, 2003.

PANDEY, K. K.; UPRETI, N. K.; SRINIVASAN, V. V. A fluorescence spectroscopic study on wood. Wood science and technology, v. 32, p.309-315, 1998.

PANKEY, K. K. A study of chemical structure of soft and hardwood and wood polymers by FTIR spectroscopy. Journal of Applied Polymer Science, v. 71, p. 1969-1975, 1999.

PANSHIN, A. J.; ZEEUW, C. de. Textbook of wood technology. $3^{\text {a }}$ edição. New York: Mc Graw-Hill, 1970, 705p.

PASQUINI, C. Near infrared spectroscopy: fundamentals, practical aspects and analytical applications. Journal of the Brazilian Chemical Society, v.14, n.2, p.198-219, 2003.

PASTORE, T. C. M. Estudos do efeito da radiação ultravioleta em madeiras por espectroscopias Raman (FT-RAMAN), de refletância difusa no infravermelho (DRIFT) e no visível (CIE-L*a*b*). 2004. 131f. Tese de doutorado - Universidade de Brasília, Brasília. 
PASTORE, T.C.M.; BRAGA, J.W.B.; CORADIN, V.T.R.; MAGALHAES, W.L.E.; OKINO, E.Y.A.; CAMARGOS, J.A.A.; MUNIZ, G.I.B.; BRESSAN, O.A.; DAVRIEUX, F. Near infrared spectroscopy as a potential tool for monitoring trade of similar woods: discrimination of true mahogany, cedar, andiroba and curupixá. Holzforschung, v.65, p.7380, 2011.

PAULA, J.E.; ALVES, J.L.H. 897 madeiras nativas do Brasil: anatomia, dendrologia, dendrometria, produção e uso. Porto Alegre: Cinco Continentes, 2007. $438 \mathrm{p}$.

PAVIA, D. L.; LAMPMAN, G. M.; KRIZ, G. S.; VYVYAN, J. R. Introdução à espectroscopia. Tradução Pedro Barros. São Paulo: Cengage Learning, 2012.

PENEDO, W. R. Uso da madeira para fins energéticos. Belo Horizonte. Fundação CETEC, 1980.

PEREIRA, J. C. D.; STURION, J. A.; HIGA, A. R.; HIGA, R. C. V.; SHIMIZU, J. Y. Características de madeiras de algumas espécies de eucaliptos plantadas no Brasil. Colombo; Embrapa Florestas, 2000. 113 p. (Embrapa Florestas. Documentos, 38).

PHILLIP, P.; D’ ALMEIDA, M. L. O. Celulose e Papel. Volume I. Tecnologia e Fabricação da Pasta Celulósica. Instituto de Pesquisas Tecnológicas do Estado de São Paulo - Centro Técnico em celulose e papel. São Paulo, 1988, $2^{a}$ edição.

PISSININ, L. Z. Crescimento e produção de clones de Eucalyptus saligna Smith sob diferentes condições ambientais. 2013. 159f. Dissertação de mestrado - Universidade Federal de Santa Maria, Santa Maria.

PONCSÁK, S. et al. Effect of high temperature treatment on the mechanical properties of birch (Betula papyrifera). Wood Science Technology, v. 40, p. 647-663, 2006.

PUEHRINGER, C. H. Uso de emissão de ondas de tensão para avaliação não destrutiva de árvores e da madeira de Pinus taeda L. 2002. 114f. Dissertação de mestrado - Universidade Federal do Paraná, Curitiba.

RAMOS, L. P.; The chemistry involved in the steam treatment of lignocellulosic materials. Quimica Nova, v.26, n.6, p.863-871, 2003. 
RAPPOLD, P.M.; SMITH, W.B. An investigation of the relationships between harvest season, log age, and drying schedule on the coloration of hard maple lumber. Forest Products Journal, v.54, n.12, p.178-184, 2004.

RIBEIRO, P. G. Utilização de técnicas não destrutivas para caracterização e madeiras de Pinu caribaea var. hondurensis e de Eucalyptus grandis. 2009. 114f. Dissertação de mestrado - Universidade de Brasília, Brasília.

RIZZINI, C. R. Árvores e madeiras úteis do Brasil. São Paulo: Blücher, 1978. 296p.

ROCHA, M. P. Biodegradação e preservação da madeira. $5^{\text {a }}$ edição. Curitiba: Fundação de Pesquisas Florestais do Paraná, 2001. 94 p. (Série Didática, 01/01).

ROSS, R. J. Using sound to evaluate standing timber: review. Forest products journal, n.1, p. 43-44, 1999.

ROSS, R. J.; BRASHAW, B. K.; PELLERIN, R. F. Nondestructive evaluation of wood. Forest Products Journal, v. 48, n.1, p.14-19, 1998.

ROWELL, R. M.; PETTERSEN, R.; HAN, J. S.; ROWELL, J. S.; TSHABALALA, M. A. Cell Wall Chemistry. In: Handbook of Wood Chemistry and Wood Composites. Editado por Roger M. Rowell. Ney York: Editora Taylor \& Francis Group, 2005.

ROWELL, R.M. Wood chemistry and wood composites. Boca Raton: CRC Press, 2005. 473p.

SALA, O.; Fundamentos da Espectroscopia Raman e no Infravermelho. $2^{\text {a }}$ edição. São Paulo: Ed. Unesp, 2008.

SANTANA, M. A. E.; OKINO, E. Y. A. Chemical composition of 36 Brazilian Amazon forest wood species. Holzforschung, v.61, n.5, p.469-477, 2007.

SANTOS, Z. M. Avaliação da durabilidade natural da madeira de Eucalyptus grandis W. Hill: Maiden em ensaios de laboratório. 1992. 75f. Dissertação de mestrado - Universidade Federal de Viçosa, Viçosa.

SCHAD, K. C.; SCHMOLDT, D. L.; ROSS, R. J. Nondestructive methods for detecting defects in softwood logs. US Forest Laboratory. Research Paper FPL, n. 546, 1996. 
SCHEFFER, T.C. Microbiological degradation and the causal organism. In: Nicholas, D.D. (ed.) Wood deterioration and its prevention by preservative treatments. v.1. Syracuse University Press, Syracuse. p.31-106, 1973.

SCHERER, M. D. Caracterização óptica do diesel, biodiesel, óleo e suas misturas: Desenvolvimento de uma metodologia alternativa para a quantificação do teor de biodiesel na mistura diesel/biodiesel. 2011. 98f. Dissertação de mestrado Universidade Federal da Grande Dourados, Dourados.

SCHORN, L. A. Silvicultura de espécies exóticas.

SENESI, N. Analytica Chimica Acta. v.232, p.77-106, 1990.

SILVA, C. A. Análise da composição da madeira de Caesalpinia echinata Lam. (Pau-Brasil): subsídios para o entendimento de sua estrutura e resistência a organismos xilófagos. 2007. 120p. Tese de doutorado - Universidade Estadual de Campinas, Campinas.

SILVA, G. B. Colorimetria - Propagação de erros e cálculo da incerteza de medição nos resultados espectrofotométricos. Dissertação de mestrado - PUC-Rio, Rio de Janeiro, 2004.

SILVA, J.O.; PASTORE, T.C. M.; PASTORE JUNIOR, F. RESISTÊNCIA AO INTEMPERISMO ARTIFICIAL DE CINCO MADEIRAS TROPICAIS E DE DOIS PRODUTOS DE ACABAMENTO. Ciência Florestal, v. 17, n. 1, p. 17-23, 2007F.

SILVA, J.O.; PASTORE, T.C.M. Fotodecomposição e proteção de madeiras tropicais. Floresta e Ambiente, v.11, n.2, p.7-13, 2004.

SILVA, L. F.; PAES J. B.; JÚNIOR, W. C. J.; OLIVEIRA, J. T. S.; FURTADO, E. L.; ALVES, F. R. Deterioração da madeira de Eucalyptus spp. por fungos xilófagos. Cerne, v. 20 , n. 3, p. 393-400, 2014.

SILVA, M. V. Uso da espectroscopia óptica e espectrometria de lente térmica no estudo de blendas óleo-biodiesel e biodiesel-diesel. 2012. 98f. Dissertação de mestrado Universidade Estadual do Mato Grosso do Sul, Dourados, 2012.

SILVA, V. L. Caracterização de ligninas de Eucalyptus spp. pela técnica e pirólise associada à cromatografia gasosa e à espectrometria de massas. $2006.85 f$. Dissertação de mestrado - Universidade Federal de Viçosa. Viçosa. 
SILVERSTEIN, R. M.; WEBSTER, F. X.; KIEMLE, D. J. Identificaçãa espectrométrica de compostos orgânicos. Tradução Ricardo Bicca de Alencastro. Rio de Janeiro: LTC, 2012.

SJÖSTRÖM, E. Wood chemistry: fundamentals and applications. $2^{\text {a }}$ edição. San Diego: Academic Press, 1993, 293p.

SJÖSTRÖM, E.; ALÉN, R. Analytical methods in wood chemistry, pulping and papermaking. $15^{\text {a }}$ edição. Berlin: Springer- Verlag, 1999, 316 p.

SKOOG, D. A.; HOLleR, F. J.; NIEMAN, T. A. Princípios de análise instrumental. Tradução: Ignez Caracelli, Paulo Celso Isolani, Regina Helena de Almeida Santos, Regina Helena Porto Francisco. $5^{\text {a }}$ edição. Porto Alegre: Bookman, 2002, 836p.

SKOOG, D. A.; WEST, D. M.; HOLLER, F. J.; CROUCH, S. R. Fundamentos de Química Analítica. 8a edição. São Paulo: Cengage Learning, 2009, 999p.

SOTOMAYOR, M. D. P. T.; DIAS, I. L. T.; LANZA, M. R. V.; MOREIRA, A. B.; KUBOTA, L. T. Aplicação e avanços da espectroscopia de luminescência em análises farmacêuticas. Química Nova, v.31, n.7, p.1755-1774, 2008.

SOUZA, F.; TELES, R. F.; RIBEIRO, P. G.; CAMARGOS, A. M.; DEL MENEZZI, C. H. S. Resistência natural e alteração da cor da madeira de Machaerium scleroxylon Tul. submetida ao ataque de fungos apodrecedores. Scientia Forestalis, v.38, n.87, p.449-457, 2010.

SOUZA, M. H.; MAGLIANO, M. M.; CAMARGOS, J. A. A; SOUZA, M. R. Madeiras tropicais brasileiras. $2^{\mathrm{a}}$ edição. Brasília: Edições Ibama, 2002, 152p.

STANGERLIN, D. M. Monitoramento de propriedades de madeiras da Amazônia submetidas ao ataque de fungos apodrecedores. 2012. 259f. Tese de doutorado - Universidade de Brasília, Brasília.

STANGERlin, D. M.; COSTA, A. F.; GARlet, A.; PASTORE, T. C. M. Resistência natural da madeira de três espécies amazônicas submetidas ao ataque de fungos apodrecedores. Ciência da Madeira (Braz. J. Wood Sci.), v.04, n.01, p.15-32, 2013.

STENUDD, S. Color response in silver birch during kiln-drying. Forest Products Journal, v.54, n.6, p.31-36, 2004. 
STONE, H. 1921. A text-book of woods: 52.

STURCOVA, A.; HIS, I.; APPERLEY, D. C.; SUGIYAMA, J.; JARVIS, M. C. Structural details of crystaline cellulose from higher plants. Biomacromolecules, v.5, p.1333-1339. 2004.

TAIZ, L.; ZEIGER, E. Fisiologia vegetal. 4a edição. Porto Alegre: Artmed, 2009. $819 \mathrm{p}$.

TANAKA, H.; ITAKURA, S.; ENOKI, A. Hydroxyl radical generation by na extracellular low-molecular-weight substance and phenol oxidase activity during wood degradation by the white-rot basidiomycete Trametes versicolor. Journal of Biotechnology, v. 75 , n. 1 , p. $57-70,1999$.

TEIXEIRA, J. G.; OLIVEIRA, B. R. U. de; LATORRACA, J. V. de F.; AMODEI, J.B.; GURGEL, M. de M. Emissão de fluorescência do cerne de espécies tropicais. Ciência da Madeira (Braz. J. Wood Sci.), v.3, n.1, p.11-21, 2012.

TELES, R. F. Ensaios não destrutivos para avaliar o desempenho de madeiras amazônicas tratadas quimicamente. 2014. 209f. Tese de doutorado - Universidade de Brasília, Brasília, 2014.

TOLVAJ, L.; FAIX, O. Artificial ageing of wood monitored by DRIFT spectroscopy and CIE L*a*b* color measurements. Holzforshung, v.49, p.397-404, 1995.

TOMAZELLO FILHO, M. Variação radial da densidade básica e da estrutura anatômica de Eucalyptus saligna e Eucalyptus grandis. IPEF, n. 29, p. 37-45, 1985.

TRUGILHO, P. F., LIMA, J. T., MENDES, L. M. Influência da idade nas características físicoquímicas e anatômicas da madeira de Eucalyptus saligna. Cerne, v.2, n.1, 1996.

TRUGILHO, P. F.; MENDES, L. M.; SILVA, J. R. M.; LIMA, J. T. Influência da idade nas características físicas, químicas e anatômicas da madeira de Eucalyptus grandis. In: Proceedings of the 4th IUFRO Conference on Silviculture and Improvement of Eucalyptus, 1997, Salvador, p. 269-275.

TSOUMIS, G. Science and technology of wood: structure, properties, utilization. New York: Chapman e Hall, 1991. 
VALEUR, B. Molecular fluorescence: Principles and applications. 2001 ISBNs: 3-527-29919-X (Hardcover); 3-527-60024-8 (Electronic)

VIANA, L.C. Uso da espectroscopia no infravermelho próximo para predição de propriedades tecnológicas da madeira de Eucalyptus. 2008. 120f. Dissertação de Mestrado - Universidade Federal de Lavras, Lavras.

WHEELER, E. A.; BAAS, P.; GASSON, P. E. IAWA Committee. Bull. n. s. v.10, n.3, p. 219-332, 1989.

ZABEL, R. A., MORRELL, J. J. Wood Microbiology: Decay and its preservation. San Diego: Academic Press, 1992.

ZANUNCIO, A. J. V., FARIAS, E. S., SILVEIRA, T.A. Termorretificação e colorimetria da madeira de Eucalyptus grandis. Floresta e Ambiente, v.21, n.1, p.85-90, 2014.

ZÚÑIGA, U. F. R. Avaliação da influência de fatores ambientais na estrutura, dinâmica e propriedades ópticas das substâncias húmicas aquáticas do Rio Negro. Dissertação de mestrado - Universidade de São Paulo, São Carlos, 2006. 
APÊNDICES 


\section{A - Perda de massa das madeiras de Simarouba amara e Eucalyptus saligna após exposição aos fungos apodrecedores.}

\begin{tabular}{|c|c|c|c|c|c|c|c|c|}
\hline \multirow{3}{*}{$\begin{array}{c}\text { Período } \\
\text { (Semanas) }\end{array}$} & \multicolumn{4}{|c|}{ Simarouba amara } & \multicolumn{4}{|c|}{ Eucalyptus saligna } \\
\hline & \multicolumn{2}{|c|}{ TV } & \multicolumn{2}{|c|}{ GT } & \multicolumn{2}{|c|}{ TV } & \multicolumn{2}{|c|}{ GT } \\
\hline & $\mathrm{PM}(\%)$ & $\mathrm{CR}$ & PM (\%) & $\mathrm{CR}$ & PM (\%) & $\mathrm{CR}$ & PM (\%) & $\mathrm{CR}$ \\
\hline \multirow{2}{*}{0} & $0 \mathrm{j}^{*}$ & \multirow{2}{*}{ MR } & 01 & \multirow{2}{*}{ MR } & $0 \mathrm{c}$ & \multirow{2}{*}{ MR } & $0 \mathrm{f}$ & \multirow{2}{*}{ MR } \\
\hline & $(0)$ & & $(0)$ & & $(0)$ & & $(0)$ & \\
\hline 1 & $\begin{array}{c}0,68 \mathrm{jA} \\
(0.39)\end{array}$ & MR & $\begin{array}{c}0,671 \mathrm{~A} \\
(0,32)\end{array}$ & MR & $\begin{array}{c}0,10 \mathrm{cA} \\
(0,21)\end{array}$ & MR & $\begin{array}{c}0,12 \text { fA } \\
(0,14)\end{array}$ & MR \\
\hline 2 & $\begin{array}{c}5,63 \mathrm{iB} \\
(1,03)\end{array}$ & MR & $\begin{array}{c}7,96 \mathrm{jA} \\
(1,99)\end{array}$ & MR & $\begin{array}{c}1,16 \mathrm{cB} \\
(0,73)\end{array}$ & MR & $\begin{array}{c}2,91 \mathrm{fA} \\
(1,45)\end{array}$ & MR \\
\hline 3 & $\begin{array}{c}10,79 \mathrm{hB} \\
(1,03)\end{array}$ & MR & $\begin{array}{c}14,97 \mathrm{iA} \\
(1,27)\end{array}$ & $\mathrm{R}$ & $\begin{array}{c}3,01 \mathrm{cB} \\
(2,73)\end{array}$ & MR & $\begin{array}{c}5,72 \mathrm{eA} \\
(2,65)\end{array}$ & MR \\
\hline 4 & $\begin{array}{c}15,19 \mathrm{gB} \\
(0,90)\end{array}$ & $\mathrm{R}$ & $\begin{array}{c}20,78 \mathrm{hA} \\
(2,09)\end{array}$ & $\mathrm{R}$ & $\begin{array}{c}7,88 \mathrm{bA} \\
(4,71)\end{array}$ & MR & $\begin{array}{c}8,39 \mathrm{eA} \\
(3,52)\end{array}$ & MR \\
\hline 5 & $\begin{array}{c}18,84 \mathrm{fB} \\
(2,64)\end{array}$ & $\mathrm{R}$ & $\begin{array}{c}23,92 \mathrm{gA} \\
(1,69)\end{array}$ & $\mathrm{R}$ & $\begin{array}{c}7,64 \mathrm{bB} \\
(5,81)\end{array}$ & MR & $\begin{array}{c}15,66 \mathrm{dA} \\
(4,89)\end{array}$ & $\mathrm{R}$ \\
\hline 6 & $\begin{array}{c}18,80 \mathrm{fB} \\
(3,31)\end{array}$ & $\mathrm{R}$ & $\begin{array}{c}26,97 \mathrm{fA} \\
(1,44)\end{array}$ & $\mathrm{RM}$ & $\begin{array}{c}8,66 \mathrm{bB} \\
(7,23)\end{array}$ & MR & $\begin{array}{c}18,34 \mathrm{dA} \\
(2,25)\end{array}$ & $\mathrm{R}$ \\
\hline 7 & $\begin{array}{c}27,03 \mathrm{eB} \\
(2,70)\end{array}$ & $\mathrm{RM}$ & $\begin{array}{c}30,66 \text { eA } \\
(2,69)\end{array}$ & RM & $\begin{array}{c}8,77 \mathrm{bB} \\
(7,51)\end{array}$ & MR & $\begin{array}{c}18,07 \mathrm{dA} \\
(3,65)\end{array}$ & $\mathrm{R}$ \\
\hline 8 & $\begin{array}{c}27,47 \mathrm{eB} \\
(3,09)\end{array}$ & $\mathrm{RM}$ & $\begin{array}{c}30,37 \mathrm{eA} \\
(2,28)\end{array}$ & RM & $\begin{array}{c}9,90 \mathrm{bB} \\
(6,87)\end{array}$ & MR & $\begin{array}{c}20,43 \mathrm{cA} \\
(11,50)\end{array}$ & $\mathrm{R}$ \\
\hline 9 & $\begin{array}{c}30,72 \mathrm{~dB} \\
(3,63)\end{array}$ & $\mathrm{RM}$ & $\begin{array}{c}36,24 \mathrm{dA} \\
(2,99)\end{array}$ & RM & $\begin{array}{c}12,39 \mathrm{bB} \\
(10,56)\end{array}$ & $\mathrm{R}$ & $\begin{array}{c}22,66 \mathrm{cA} \\
(6,12)\end{array}$ & $\mathrm{R}$ \\
\hline 10 & $\begin{array}{c}33,42 \mathrm{cB} \\
(4,61)\end{array}$ & RM & $\begin{array}{c}38,32 \mathrm{cA} \\
(2,13)\end{array}$ & RM & $\begin{array}{c}17,49 \mathrm{aB} \\
(12,66)\end{array}$ & $\mathrm{R}$ & $\begin{array}{c}26,58 \mathrm{bA} \\
(4,56)\end{array}$ & RM \\
\hline 11 & $\begin{array}{c}40,03 \mathrm{bA} \\
(4,14)\end{array}$ & $\mathrm{RM}$ & $\begin{array}{c}42,94 \mathrm{bA} \\
(2,63)\end{array}$ & RM & $\begin{array}{c}18,68 \mathrm{aA} \\
(18,77)\end{array}$ & $\mathrm{R}$ & $\begin{array}{c}28,49 \mathrm{bA} \\
(4,53)\end{array}$ & $\mathrm{RM}$ \\
\hline 12 & $\begin{array}{c}42,54 \mathrm{aA} \\
(5,50)\end{array}$ & $\mathrm{RM}$ & $\begin{array}{c}45,71 \mathrm{aA} \\
(2,70)\end{array}$ & NR & $\begin{array}{c}23,19 \mathrm{aA} \\
(15,65)\end{array}$ & $\mathrm{R}$ & $\begin{array}{c}32,12 \text { aA } \\
(5,33)\end{array}$ & $\mathrm{RM}$ \\
\hline
\end{tabular}

Em que: $\mathrm{TV}=$ Trametes versicolor $; \mathrm{GT}=$ Gloeophyllum trabeum $; \mathrm{PM}(\%)=$ perda de massa em porcentagem; $\mathrm{CR}=$ classes de resistência; $\mathrm{MR}=$ muito resistente; $\mathrm{R}=$ resistente; $\mathrm{RM}=$ resistência moderada; $\mathrm{NR}=$ não resistente. *Dentro de uma mesma espécie de madeira, médias não seguidas por uma mesma letra minúscula na vertical ou uma mesma letra maiúscula na horizontal diferem estatisticamente a 5\% de probabilidade pelo teste de Scott-Knott. Os valores entre parênteses são referentes ao desvio padrão. 


\section{B - Alteração dos parâmetros colorimétricos de Simarouba amara após exposição aos fungos apodrecedores}

\begin{tabular}{|c|c|c|c|c|c|c|c|c|c|c|}
\hline \multirow{2}{*}{ Período (Semanas) } & \multicolumn{2}{|c|}{$\mathbf{L}^{*}$} & \multicolumn{2}{|c|}{$\mathbf{a}^{*}$} & \multicolumn{2}{|c|}{$\mathbf{b}^{*}$} & \multicolumn{2}{|c|}{$\mathbf{C}$} & \multicolumn{2}{|c|}{ h* } \\
\hline & $\mathrm{TV}$ & GT & TV & GT & TV & GT & TV & GT & TV & GT \\
\hline 0 & $\begin{array}{c}83,43 \mathrm{a} \\
(1,69)\end{array}$ & $\begin{array}{c}83,43 \mathrm{a} \\
(1,69)\end{array}$ & $\begin{array}{l}3,42 \mathrm{~d} \\
(0.57)\end{array}$ & $\begin{array}{l}3,42 \mathrm{f} \\
(0,57)\end{array}$ & $\begin{array}{c}22,70 \mathrm{e} \\
(1,14)\end{array}$ & $\begin{array}{c}22,70 \mathrm{~d} \\
(1,14)\end{array}$ & $\begin{array}{c}22,96 \mathrm{e} \\
(1,20)\end{array}$ & $\begin{array}{c}22,96 \mathrm{~d} \\
(1,20)\end{array}$ & $\begin{array}{c}81,48 \text { a } \\
(1,04)\end{array}$ & $\begin{array}{c}81,48 \text { a } \\
(1,04)\end{array}$ \\
\hline 1 & $\begin{array}{c}78,22 \mathrm{bA} \\
(2,19) \\
\end{array}$ & $\begin{array}{c}69,76 \mathrm{bB} \\
(3,01) \\
\end{array}$ & $\begin{array}{c}5,96 \mathrm{bB} \\
(1,03)\end{array}$ & $\begin{array}{c}7,71 \mathrm{eA} \\
(0,71) \\
\end{array}$ & $\begin{array}{c}28,28 \mathrm{~dB} \\
(2,64) \\
\end{array}$ & $\begin{array}{c}31,02 \mathrm{aA} \\
(1,36)\end{array}$ & $\begin{array}{c}28,89 \mathrm{~dB} \\
(2,72) \\
\end{array}$ & $\begin{array}{c}31,98 \mathrm{bA} \\
(1,44) \\
\end{array}$ & $\begin{array}{c}78,10 \mathrm{cA} \\
(1,62) \\
\end{array}$ & $\begin{array}{c}76,08 \text { bB } \\
(0,93) \\
\end{array}$ \\
\hline 2 & $\begin{array}{c}77,62 \mathrm{bA} \\
(1,51)\end{array}$ & $\begin{array}{c}60,70 \mathrm{cB} \\
(5,10)\end{array}$ & $\begin{array}{c}6,70 \mathrm{bB} \\
(0,53)\end{array}$ & $\begin{array}{c}9,81 \mathrm{cA} \\
(1,90)\end{array}$ & $\begin{array}{c}31,99 \mathrm{cA} \\
(1,73)\end{array}$ & $\begin{array}{c}32,81 \mathrm{aA} \\
(2,04)\end{array}$ & $\begin{array}{c}32,68 \mathrm{cA} \\
(1,73)\end{array}$ & $\begin{array}{c}34,28 \text { aA } \\
(2,36)\end{array}$ & $\begin{array}{c}78,16 \mathrm{cA} \\
(0,95)\end{array}$ & $\begin{array}{c}73,47 \mathrm{cB} \\
(2,51)\end{array}$ \\
\hline 3 & $\begin{array}{c}78,20 \mathrm{bA} \\
(1,60)\end{array}$ & $\begin{array}{c}52,83 \mathrm{~dB} \\
(2,96)\end{array}$ & $\begin{array}{c}6,75 \mathrm{bB} \\
(0,67)\end{array}$ & $\begin{array}{c}9,36 \mathrm{dA} \\
(1,52)\end{array}$ & $\begin{array}{c}31,50 \mathrm{cA} \\
(1,16)\end{array}$ & $\begin{array}{c}29,90 \mathrm{bB} \\
(2,07)\end{array}$ & $\begin{array}{c}32,22 \mathrm{cA} \\
(1,17)\end{array}$ & $\begin{array}{c}31,35 \mathrm{bA} \\
(2,37)\end{array}$ & $\begin{array}{c}77,91 \mathrm{cA} \\
(1,14)\end{array}$ & $\begin{array}{c}72,70 \mathrm{cB} \\
(1,77)\end{array}$ \\
\hline 4 & $\begin{array}{c}78,38 \mathrm{bA} \\
(1,93) \\
\end{array}$ & $\begin{array}{c}50,93 \mathrm{~dB} \\
(3,27) \\
\end{array}$ & $\begin{array}{c}6,53 \mathrm{bB} \\
(0,95) \\
\end{array}$ & $\begin{array}{c}10,29 \mathrm{cA} \\
(0,96)\end{array}$ & $\begin{array}{c}30,72 \mathrm{cA} \\
(1,39) \\
\end{array}$ & $\begin{array}{c}30,02 \mathrm{bA} \\
(2,19) \\
\end{array}$ & $\begin{array}{c}31,41 \mathrm{cA} \\
(1,50) \\
\end{array}$ & $\begin{array}{c}31,74 \mathrm{bA} \\
(2,36) \\
\end{array}$ & $\begin{array}{c}78,03 \mathrm{cA} \\
(1,40) \\
\end{array}$ & $\begin{array}{c}71,10 \mathrm{~dB} \\
(0,71)\end{array}$ \\
\hline 5 & $\begin{array}{c}78,59 \mathrm{bA} \\
(1,75)\end{array}$ & $\begin{array}{c}51,97 \mathrm{~dB} \\
(5,21)\end{array}$ & $\begin{array}{c}6,04 \mathrm{bB} \\
(0,73)\end{array}$ & $\begin{array}{c}10,37 \mathrm{cA} \\
(1,20)\end{array}$ & $\begin{array}{c}30,12 \mathrm{cA} \\
(1,30)\end{array}$ & $\begin{array}{c}30,40 \mathrm{bA} \\
(1,79)\end{array}$ & $\begin{array}{c}30,73 \mathrm{cA} \\
(1,35)\end{array}$ & $\begin{array}{c}32,13 \mathrm{bA} \\
(1,93)\end{array}$ & $\begin{array}{c}78,68 \mathrm{cA} \\
(1,18)\end{array}$ & $\begin{array}{c}71,18 \mathrm{~dB} \\
(1,69)\end{array}$ \\
\hline 6 & $\begin{array}{c}81,75 \text { aA } \\
(1,16)\end{array}$ & $\begin{array}{c}50,80 \mathrm{~dB} \\
(3,97)\end{array}$ & $\begin{array}{c}5,11 \mathrm{cB} \\
(0,53)\end{array}$ & $\begin{array}{c}10,98 \mathrm{bA} \\
(0,94)\end{array}$ & $\begin{array}{c}28,56 \mathrm{~dB} \\
(1,28)\end{array}$ & $\begin{array}{c}31,13 \mathrm{aA} \\
(1,81)\end{array}$ & $\begin{array}{c}29,02 \mathrm{~dB} \\
(1,34)\end{array}$ & $\begin{array}{c}33,02 \text { aA } \\
(1,86)\end{array}$ & $\begin{array}{c}79,89 \mathrm{bA} \\
(0,66)\end{array}$ & $\begin{array}{c}70,57 \mathrm{~dB} \\
(1,51)\end{array}$ \\
\hline 7 & $\begin{array}{c}77,92 \mathrm{bA} \\
(2,42) \\
\end{array}$ & $\begin{array}{c}47,20 \mathrm{eB} \\
(5,95) \\
\end{array}$ & $\begin{array}{c}6,55 \mathrm{bB} \\
(1,24) \\
\end{array}$ & $\begin{array}{c}9,87 \mathrm{cA} \\
(1,00) \\
\end{array}$ & $\begin{array}{c}30,47 \mathrm{cA} \\
(2,04) \\
\end{array}$ & $\begin{array}{c}27,39 \mathrm{cB} \\
(2,33) \\
\end{array}$ & $\begin{array}{c}31,18 \mathrm{cA} \\
(2,24) \\
\end{array}$ & $\begin{array}{c}29,15 \mathrm{cB} \\
(2,09) \\
\end{array}$ & $\begin{array}{c}77,96 \mathrm{cA} \\
(1,52) \\
\end{array}$ & $\begin{array}{c}70,06 \mathrm{~dB} \\
(2,80) \\
\end{array}$ \\
\hline 8 & $\begin{array}{c}78,03 \mathrm{bA} \\
(2,55) \\
\end{array}$ & $\begin{array}{c}45,77 \mathrm{eB} \\
(4,66)\end{array}$ & $\begin{array}{c}6,87 \mathrm{bB} \\
(1,51) \\
\end{array}$ & $\begin{array}{c}10,26 \mathrm{cA} \\
(0,83) \\
\end{array}$ & $\begin{array}{c}31,38 \mathrm{cA} \\
(2,99) \\
\end{array}$ & $\begin{array}{c}27,52 \mathrm{cB} \\
(1,85) \\
\end{array}$ & $\begin{array}{c}32,13 \mathrm{cA} \\
(3,21)\end{array}$ & $\begin{array}{c}29,40 \mathrm{cB} \\
(1,69) \\
\end{array}$ & $\begin{array}{c}77,78 \mathrm{cA} \\
(1,72) \\
\end{array}$ & $\begin{array}{c}69,48 \text { eB } \\
(2,27) \\
\end{array}$ \\
\hline 9 & $\begin{array}{c}74,73 \mathrm{cA} \\
(3,36) \\
\end{array}$ & $\begin{array}{c}45,51 \mathrm{eB} \\
(3,94)\end{array}$ & $\begin{array}{c}8,24 \mathrm{aB} \\
(1,85)\end{array}$ & $\begin{array}{c}11,21 \mathrm{bA} \\
(0,81)\end{array}$ & $\begin{array}{c}32,92 \text { bA } \\
(3,42)\end{array}$ & $\begin{array}{c}28,21 \mathrm{cB} \\
(2,49) \\
\end{array}$ & $\begin{array}{c}33,95 \mathrm{bA} \\
(3,74) \\
\end{array}$ & $\begin{array}{c}30,38 \mathrm{cB} \\
(2,34) \\
\end{array}$ & $\begin{array}{c}76,13 \mathrm{dA} \\
(1,90) \\
\end{array}$ & $\begin{array}{c}68,22 \mathrm{fB} \\
(2,22) \\
\end{array}$ \\
\hline 10 & $\begin{array}{c}75,27 \mathrm{cA} \\
(1,34) \\
\end{array}$ & $\begin{array}{c}45,06 \mathrm{eB} \\
(3,72)\end{array}$ & $\begin{array}{c}8,69 \mathrm{aB} \\
(0,72)\end{array}$ & $\begin{array}{c}11,99 \mathrm{aA} \\
(1,01)\end{array}$ & $\begin{array}{c}35,52 \mathrm{aA} \\
(1,34)\end{array}$ & $\begin{array}{c}28,83 \mathrm{bB} \\
(2,20) \\
\end{array}$ & $\begin{array}{c}36,58 \mathrm{aA} \\
(1,41) \\
\end{array}$ & $\begin{array}{c}31,25 \mathrm{bB} \\
(2,11) \\
\end{array}$ & $\begin{array}{c}76,28 \mathrm{dA} \\
(0,88) \\
\end{array}$ & $\begin{array}{c}67,35 \mathrm{fB} \\
(2,22) \\
\end{array}$ \\
\hline 11 & $\begin{array}{c}75,20 \mathrm{cA} \\
(1,17) \\
\end{array}$ & $\begin{array}{c}42,67 \mathrm{fB} \\
(5,48)\end{array}$ & $\begin{array}{c}8,25 \mathrm{aB} \\
(0,60) \\
\end{array}$ & $\begin{array}{c}10,92 \mathrm{bA} \\
(0,62) \\
\end{array}$ & $\begin{array}{c}35,39 \mathrm{aA} \\
(1,23) \\
\end{array}$ & $\begin{array}{c}26,62 \mathrm{cB} \\
(3,20)\end{array}$ & $\begin{array}{c}36,34 \mathrm{aA} \\
(1,31) \\
\end{array}$ & $\begin{array}{c}28,80 \mathrm{cB} \\
(3,04)\end{array}$ & $\begin{array}{c}76,89 \mathrm{dA} \\
(0,64) \\
\end{array}$ & $\begin{array}{c}67,48 \mathrm{fB} \\
(2,32) \\
\end{array}$ \\
\hline 12 & $\begin{array}{c}77,82 \mathrm{bA} \\
(4,39)\end{array}$ & $\begin{array}{c}41,41 \mathrm{fB} \\
(5,44)\end{array}$ & $\begin{array}{c}7,74 \mathrm{aB} \\
(2,65)\end{array}$ & $\begin{array}{c}10,69 \mathrm{cA} \\
(0,63)\end{array}$ & $\begin{array}{c}33,35 \mathrm{bA} \\
(4,57)\end{array}$ & $\begin{array}{c}25,94 \mathrm{cB} \\
(3,69)\end{array}$ & $\begin{array}{c}34,28 \mathrm{bA} \\
(5,03)\end{array}$ & $\begin{array}{c}28,11 \mathrm{cB} \\
(3,28)\end{array}$ & $\begin{array}{c}77,28 \mathrm{dA} \\
(2,66)\end{array}$ & $\begin{array}{c}67,21 \mathrm{fB} \\
(3,76)\end{array}$ \\
\hline
\end{tabular}

Em que: $\mathrm{TV}=$ Trametes versicolor; $\mathrm{GT}=$ Gloeophyllum trabeum; L*= claridade; $\mathrm{a}^{*}=$ coordenada verde-vermelho; $\mathrm{b}^{*}=\mathrm{coordenada}$ azulamarelo; $\mathrm{C}=$ saturação da cor; $\mathrm{h}^{*}=$ ângulo de tinta. *Para cada parâmetro, médias não seguidas por uma mesma letra minúscula na vertical ou uma mesma letra maiúscula na horizontal diferem estatisticamente a $5 \%$ de probabilidade pelo teste de Scott-Knott. Os valores entre parênteses são referentes ao desvio padrão. 


\section{C - Alteração dos parâmetros colorimétricos de Eucalyptus saligna após exposição aos fungos apodrecedores}

\begin{tabular}{|c|c|c|c|c|c|c|c|c|c|c|}
\hline \multirow{2}{*}{ Período (Semanas) } & \multicolumn{2}{|c|}{$\mathbf{L}^{*}$} & \multicolumn{2}{|c|}{$\mathbf{a}^{*}$} & \multicolumn{2}{|c|}{$\mathbf{b}^{*}$} & \multicolumn{2}{|c|}{$\mathbf{C}$} & \multicolumn{2}{|c|}{ h* } \\
\hline & $\mathrm{TV}$ & GT & TV & GT & TV & GT & TV & GT & TV & GT \\
\hline 0 & $\begin{array}{c}68,01 \mathrm{a} \\
(2,13)\end{array}$ & $\begin{array}{c}68,01 \mathrm{a} \\
(2,13)\end{array}$ & $\begin{array}{l}9,59 \mathrm{a} \\
(0,92)\end{array}$ & $\begin{array}{l}9,59 \mathrm{a} \\
(0,92)\end{array}$ & $\begin{array}{c}20,55 \mathrm{~b} \\
(1,24)\end{array}$ & $\begin{array}{c}20,55 \mathrm{c} \\
(1,24)\end{array}$ & $\begin{array}{c}22,69 \mathrm{~b} \\
(1,34)\end{array}$ & $\begin{array}{c}22,69 \mathrm{~b} \\
(1,34)\end{array}$ & $\begin{array}{c}65,01 \mathrm{c} \\
(1,93)\end{array}$ & $\begin{array}{c}65,01 \mathrm{c} \\
(1,93)\end{array}$ \\
\hline 1 & $\begin{array}{c}69,59 \mathrm{aA} \\
(4,11) \\
\end{array}$ & $\begin{array}{c}70,73 \mathrm{aA} \\
(4,67) \\
\end{array}$ & $\begin{array}{c}7,38 \mathrm{bA} \\
(1,58)\end{array}$ & $\begin{array}{c}5,62 \mathrm{cB} \\
(1,54)\end{array}$ & $\begin{array}{c}21,65 \mathrm{bB} \\
(2,19) \\
\end{array}$ & $\begin{array}{c}23,58 \mathrm{bA} \\
(1,67) \\
\end{array}$ & $\begin{array}{c}22,94 \mathrm{bA} \\
(2,06) \\
\end{array}$ & $\begin{array}{c}24,29 \mathrm{bA} \\
(1,66) \\
\end{array}$ & $\begin{array}{c}71,10 \mathrm{bB} \\
(4,53) \\
\end{array}$ & $\begin{array}{c}76,58 \mathrm{aA} \\
(3,68) \\
\end{array}$ \\
\hline 2 & $\begin{array}{c}72,98 \mathrm{aA} \\
(3,97)\end{array}$ & $\begin{array}{c}61,16 \mathrm{bB} \\
(3,49)\end{array}$ & $\begin{array}{c}6,32 \mathrm{cA} \\
(1,56)\end{array}$ & $\begin{array}{c}7,56 \mathrm{bA} \\
(2,07)\end{array}$ & $\begin{array}{c}22,02 \mathrm{bB} \\
(1,18)\end{array}$ & $\begin{array}{c}28,41 \text { aA } \\
(2,42)\end{array}$ & $\begin{array}{c}22,96 \mathrm{bB} \\
(1,36)\end{array}$ & $\begin{array}{c}29,44 \mathrm{aA} \\
(2,75)\end{array}$ & $\begin{array}{c}74,11 \mathrm{aA} \\
(3,55)\end{array}$ & $\begin{array}{c}75,32 \text { aA } \\
(3,22)\end{array}$ \\
\hline 3 & $\begin{array}{c}70,90 \mathrm{aA} \\
(5,71)\end{array}$ & $\begin{array}{c}59,58 \mathrm{bB} \\
(7,96)\end{array}$ & $\begin{array}{c}6,01 \mathrm{cB} \\
(2,00)\end{array}$ & $\begin{array}{c}8,46 \mathrm{bA} \\
(1,67)\end{array}$ & $\begin{array}{c}21,45 \mathrm{bB} \\
(2,14)\end{array}$ & $\begin{array}{c}29,33 \mathrm{aA} \\
(1,59)\end{array}$ & $\begin{array}{c}22,34 \mathrm{bB} \\
(2,35)\end{array}$ & $\begin{array}{c}30,56 \mathrm{aA} \\
(1,64)\end{array}$ & $\begin{array}{c}74,67 \mathrm{aA} \\
(4,52)\end{array}$ & $\begin{array}{c}73,95 \text { aA } \\
(3,07)\end{array}$ \\
\hline 4 & $\begin{array}{c}75,60 \mathrm{aA} \\
(4,45) \\
\end{array}$ & $\begin{array}{c}55,11 \mathrm{cB} \\
(4,23) \\
\end{array}$ & $\begin{array}{c}5,40 \mathrm{cB} \\
(1,23)\end{array}$ & $\begin{array}{c}10,71 \mathrm{aA} \\
(1,91) \\
\end{array}$ & $\begin{array}{c}24,41 \mathrm{aB} \\
(2,08) \\
\end{array}$ & $\begin{array}{c}31,00 \mathrm{aA} \\
(1,90) \\
\end{array}$ & $\begin{array}{c}25,02 \mathrm{aB} \\
(2,15) \\
\end{array}$ & $\begin{array}{c}32,83 \mathrm{aA} \\
(2,32) \\
\end{array}$ & $\begin{array}{c}77,56 \mathrm{aA} \\
(2,55) \\
\end{array}$ & $\begin{array}{c}71,05 \mathrm{bB} \\
(2,41) \\
\end{array}$ \\
\hline 5 & $\begin{array}{c}71,81 \text { aA } \\
(3,10)\end{array}$ & $\begin{array}{c}52,76 \mathrm{cB} \\
(3,65)\end{array}$ & $\begin{array}{c}6,62 \mathrm{cB} \\
(1,40)\end{array}$ & $\begin{array}{c}10,13 \mathrm{aA} \\
(1,52)\end{array}$ & $\begin{array}{c}24,23 \mathrm{aB} \\
(3,61)\end{array}$ & $\begin{array}{c}30,29 \mathrm{aA} \\
(2,26)\end{array}$ & $\begin{array}{c}25,13 \mathrm{aB} \\
(3,74)\end{array}$ & $\begin{array}{c}31,98 \mathrm{aA} \\
(2,43)\end{array}$ & $\begin{array}{c}74,81 \text { aA } \\
(2,32)\end{array}$ & $\begin{array}{c}71,57 \mathrm{bB} \\
(2,28)\end{array}$ \\
\hline 6 & $\begin{array}{c}71,15 \mathrm{aA} \\
(4,18)\end{array}$ & $\begin{array}{c}53,59 \mathrm{cB} \\
(7,15)\end{array}$ & $\begin{array}{c}7,06 \mathrm{cB} \\
(2,11)\end{array}$ & $\begin{array}{c}11,34 \mathrm{aA} \\
(2,08)\end{array}$ & $\begin{array}{c}25,54 \mathrm{aB} \\
(3,50)\end{array}$ & $\begin{array}{c}30,07 \mathrm{aA} \\
(2,47)\end{array}$ & $\begin{array}{c}26,56 \mathrm{aB} \\
(3,63)\end{array}$ & $\begin{array}{c}32,18 \mathrm{aA} \\
(2,83)\end{array}$ & $\begin{array}{c}74,63 \mathrm{aA} \\
(4,03)\end{array}$ & $\begin{array}{c}69,44 \mathrm{bB} \\
(2,81)\end{array}$ \\
\hline 7 & $\begin{array}{c}69,73 \mathrm{aA} \\
(7,07) \\
\end{array}$ & $\begin{array}{c}55,59 \mathrm{cB} \\
(8,49) \\
\end{array}$ & $\begin{array}{c}6,94 \mathrm{cB} \\
(2,06)\end{array}$ & $\begin{array}{c}10,78 \mathrm{aA} \\
(2,15) \\
\end{array}$ & $\begin{array}{c}22,96 \mathrm{bB} \\
(2,65) \\
\end{array}$ & $\begin{array}{c}28,86 \mathrm{aA} \\
(2,55) \\
\end{array}$ & $\begin{array}{c}24,05 \mathrm{bB} \\
(2,88) \\
\end{array}$ & $\begin{array}{c}30,88 \mathrm{aA} \\
(2,61) \\
\end{array}$ & $\begin{array}{c}73,31 \mathrm{bA} \\
(3,94) \\
\end{array}$ & $\begin{array}{c}69,54 \mathrm{bB} \\
(3,98) \\
\end{array}$ \\
\hline 8 & $\begin{array}{c}71,36 \mathrm{aA} \\
(4,74) \\
\end{array}$ & $\begin{array}{c}51,90 \mathrm{cB} \\
(6,24) \\
\end{array}$ & $\begin{array}{c}7,00 \mathrm{cB} \\
(1,83) \\
\end{array}$ & $\begin{array}{c}10,49 \mathrm{aA} \\
(3,04)\end{array}$ & $\begin{array}{c}24,66 \mathrm{aA} \\
(2,00) \\
\end{array}$ & $\begin{array}{c}27,64 \mathrm{aA} \\
(5,07)\end{array}$ & $\begin{array}{c}25,69 \mathrm{aB} \\
(2,19) \\
\end{array}$ & $\begin{array}{c}29,64 \mathrm{aA} \\
(5,60) \\
\end{array}$ & $\begin{array}{c}74,24 \mathrm{aA} \\
(3,57) \\
\end{array}$ & $\begin{array}{c}69,69 \mathrm{bB} \\
(4,28) \\
\end{array}$ \\
\hline 9 & $\begin{array}{c}68,95 \mathrm{aA} \\
(5,35) \\
\end{array}$ & $\begin{array}{c}51,02 \mathrm{cB} \\
(7,20)\end{array}$ & $\begin{array}{c}7,81 \mathrm{bB} \\
(2,14) \\
\end{array}$ & $\begin{array}{c}11,38 \mathrm{aA} \\
(2,11) \\
\end{array}$ & $\begin{array}{c}24,35 \mathrm{aB} \\
(2,11) \\
\end{array}$ & $\begin{array}{c}29,37 \mathrm{aA} \\
(2,31) \\
\end{array}$ & $\begin{array}{c}25,66 \mathrm{aB} \\
(2,13) \\
\end{array}$ & $\begin{array}{c}31,57 \mathrm{aA} \\
(2,35) \\
\end{array}$ & $\begin{array}{c}72,30 \mathrm{bA} \\
(4,86) \\
\end{array}$ & $\begin{array}{c}68,80 \mathrm{bA} \\
(3,74)\end{array}$ \\
\hline 10 & $\begin{array}{c}70,12 \mathrm{aA} \\
(5,05) \\
\end{array}$ & $\begin{array}{c}52,74 \mathrm{cB} \\
(7,44) \\
\end{array}$ & $\begin{array}{c}7,80 \mathrm{bB} \\
(2,14)\end{array}$ & $\begin{array}{c}10,85 \mathrm{aA} \\
(1,88) \\
\end{array}$ & $\begin{array}{c}26,14 \mathrm{aB} \\
(3,35) \\
\end{array}$ & $\begin{array}{c}29,52 \mathrm{aA} \\
(2,65) \\
\end{array}$ & $\begin{array}{c}27,33 \mathrm{aB} \\
(3,63) \\
\end{array}$ & $\begin{array}{c}31,53 \mathrm{aA} \\
(2,50) \\
\end{array}$ & $\begin{array}{c}73,58 \mathrm{bA} \\
(3,46) \\
\end{array}$ & $\begin{array}{c}69,71 \mathrm{bB} \\
(3,86) \\
\end{array}$ \\
\hline 11 & $\begin{array}{c}68,95 \mathrm{aA} \\
(7,02) \\
\end{array}$ & $\begin{array}{c}48,80 \mathrm{~dB} \\
(9,67)\end{array}$ & $\begin{array}{c}7,44 \mathrm{bB} \\
(1,60)\end{array}$ & $\begin{array}{c}9,95 \mathrm{aA} \\
(2,00) \\
\end{array}$ & $\begin{array}{c}24,24 \mathrm{aA} \\
(2,92) \\
\end{array}$ & $\begin{array}{c}27,61 \mathrm{aA} \\
(6,65) \\
\end{array}$ & $\begin{array}{c}25,41 \mathrm{aA} \\
(2,93) \\
\end{array}$ & $\begin{array}{c}29,42 \mathrm{aA} \\
(6,66) \\
\end{array}$ & $\begin{array}{c}72,90 \mathrm{bA} \\
(3,57) \\
\end{array}$ & $\begin{array}{c}69,69 \mathrm{bA} \\
(4,09) \\
\end{array}$ \\
\hline 12 & $\begin{array}{c}69,72 \mathrm{aA} \\
(8,12)\end{array}$ & $\begin{array}{c}45,37 \mathrm{~dB} \\
(6,05)\end{array}$ & $\begin{array}{c}5,92 \mathrm{cB} \\
(2,04)\end{array}$ & $\begin{array}{c}11,66 \mathrm{aA} \\
(1,28)\end{array}$ & $\begin{array}{c}22,67 \mathrm{bB} \\
(2,77)\end{array}$ & $\begin{array}{c}27,74 \mathrm{aA} \\
(3,85)\end{array}$ & $\begin{array}{c}23,48 \text { bB } \\
(3,13)\end{array}$ & $\begin{array}{c}30,14 \mathrm{aA} \\
(3,77)\end{array}$ & $\begin{array}{c}75,68 \mathrm{aA} \\
(3,36)\end{array}$ & $\begin{array}{c}66,94 \mathrm{cB} \\
(2,89)\end{array}$ \\
\hline
\end{tabular}

Em que: $\mathrm{TV}=$ Trametes versicolor; $\mathrm{GT}=$ Gloeophyllum trabeum; $\mathrm{L}^{*}=$ claridade; $\mathrm{a}^{*}=$ coordenada verde-vermelho; $\mathrm{b}^{*}=$ coordenada azulamarelo; $\mathrm{C}=$ saturação da cor; $\mathrm{h}^{*}=$ ângulo de tinta. *Para cada parâmetro, médias não seguidas por uma mesma letra minúscula na vertical ou uma mesma letra maiúscula na horizontal diferem estatisticamente a $5 \%$ de probabilidade pelo teste de Scott-Knott. Os valores entre parênteses são referentes ao desvio padrão. 


\section{D - Alterações colorimétricas nas madeiras de Simarouba amara e Eucalyptus saligna}

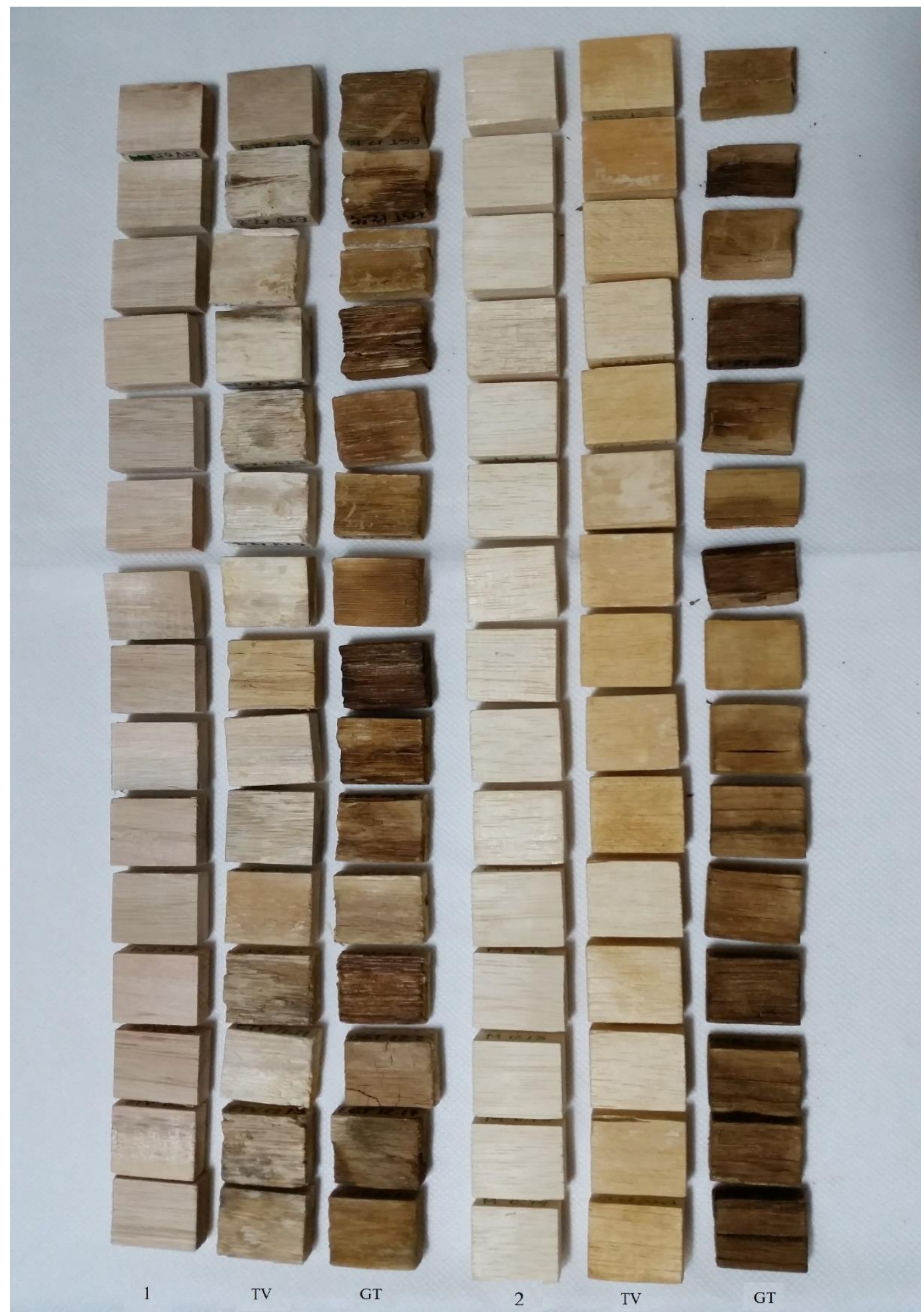

Em que: 1= Amostras testemunhas de Eucalyptus saligna; $2=$ Amostras testemunhas de Eucalyptus saligna; $\mathrm{TV}=$ Amostras após 12 semanas de exposição a Trametes versicolor; GT= Amostras após 12 semanas de exposição a Gloeophyllum trabeum. 


\section{E - Alteração da intensidade de fluorescência emitida pela madeira de Simarouba amara após exposição aos fungos apodrecedores}

\begin{tabular}{|c|c|c|c|c|}
\hline & \multicolumn{2}{|c|}{$440 \mathrm{~nm}$} & \multicolumn{2}{|c|}{$534 \mathrm{~nm}$} \\
\hline Período (Semanas) & TV & GT & TV & GT \\
\hline 0 & $\begin{array}{l}226,18 \mathrm{c} \\
(45,78)\end{array}$ & $\begin{array}{c}226,18 \text { b } \\
(45,78)\end{array}$ & $\begin{array}{c}169,99 \mathrm{c} \\
(30,60)\end{array}$ & $\begin{array}{c}169,99 \mathrm{a} \\
(30,60)\end{array}$ \\
\hline 1 & $\begin{array}{c}165,43 \mathrm{~dB} \\
(21,85)\end{array}$ & $\begin{array}{c}268,69 \mathrm{aA} \\
(90,45)\end{array}$ & $\begin{array}{c}165,44 \mathrm{cA} \\
(18,74)\end{array}$ & $\begin{array}{c}138,12 \mathrm{bA} \\
(43,52)\end{array}$ \\
\hline 2 & $\begin{array}{c}301,30 \mathrm{bA} \\
(44,90)\end{array}$ & $\begin{array}{c}153,47 \mathrm{cB} \\
(52,10)\end{array}$ & $\begin{array}{c}264,23 \mathrm{aA} \\
(30,32)\end{array}$ & $\begin{array}{c}76,89 \mathrm{cB} \\
(23,00)\end{array}$ \\
\hline 3 & $\begin{array}{c}388,60 \mathrm{aA} \\
(35,97)\end{array}$ & $\begin{array}{c}97,78 \mathrm{~dB} \\
(13,80)\end{array}$ & $\begin{array}{c}270,48 \mathrm{aA} \\
(20,82)\end{array}$ & $\begin{array}{c}48,28 \mathrm{~dB} \\
(6,56)\end{array}$ \\
\hline 4 & $\begin{array}{c}394,19 \mathrm{aA} \\
(60,76)\end{array}$ & $\begin{array}{c}101,24 \mathrm{~dB} \\
(23,03)\end{array}$ & $\begin{array}{c}266,61 \mathrm{aA} \\
(31,30)\end{array}$ & $\begin{array}{c}53,21 \mathrm{~dB} \\
(14,84)\end{array}$ \\
\hline 5 & $\begin{array}{c}356,63 \mathrm{aA} \\
(58,87)\end{array}$ & $\begin{array}{c}105,04 \mathrm{~dB} \\
(48,24)\end{array}$ & $\begin{array}{c}271,69 \mathrm{aA} \\
(28,91)\end{array}$ & $\begin{array}{c}54,77 \mathrm{~dB} \\
(20,79)\end{array}$ \\
\hline 6 & $\begin{array}{c}383,02 \mathrm{aA} \\
(92,02)\end{array}$ & $\begin{array}{c}86,93 \mathrm{~dB} \\
(22,73)\end{array}$ & $\begin{array}{c}275,53 \mathrm{aA} \\
(41,76)\end{array}$ & $\begin{array}{c}48,69 \mathrm{~dB} \\
(11,68)\end{array}$ \\
\hline 7 & $\begin{array}{c}208,53 \mathrm{cA} \\
(56,89)\end{array}$ & $\begin{array}{c}114,83 \mathrm{~dB} \\
(36,38)\end{array}$ & $\begin{array}{c}214,87 \mathrm{bA} \\
(50,21)\end{array}$ & $\begin{array}{c}61,48 \mathrm{cB} \\
(23,17)\end{array}$ \\
\hline 8 & $\begin{array}{c}158,29 \mathrm{dA} \\
(53,62)\end{array}$ & $\begin{array}{c}95,70 \mathrm{~dB} \\
(19,47)\end{array}$ & $\begin{array}{c}175,60 \mathrm{cA} \\
(50,43)\end{array}$ & $\begin{array}{c}52,71 \mathrm{~dB} \\
(10,33)\end{array}$ \\
\hline 9 & $\begin{array}{c}180,98 \mathrm{dA} \\
(78,65)\end{array}$ & $\begin{array}{c}79,99 \mathrm{~dB} \\
(19,55)\end{array}$ & $\begin{array}{c}194,44 \text { bA } \\
(59,53)\end{array}$ & $\begin{array}{c}42,23 \mathrm{~dB} \\
(7,95)\end{array}$ \\
\hline 10 & $\begin{array}{c}174,92 \mathrm{dA} \\
(75,54)\end{array}$ & $\begin{array}{c}76,73 \mathrm{~dB} \\
(17,53)\end{array}$ & $\begin{array}{c}192,18 \mathrm{bA} \\
(57,26)\end{array}$ & $\begin{array}{c}41,35 \mathrm{~dB} \\
(5,54)\end{array}$ \\
\hline 11 & $\begin{array}{c}138,07 \mathrm{dA} \\
(81,56)\end{array}$ & $\begin{array}{c}71,99 \mathrm{~dB} \\
(32,96)\end{array}$ & $\begin{array}{c}159,53 \mathrm{cA} \\
(67,65)\end{array}$ & $\begin{array}{c}40,13 \mathrm{~dB} \\
(15,96)\end{array}$ \\
\hline 12 & $\begin{array}{c}186,46 \mathrm{dA} \\
(83,26)\end{array}$ & $\begin{array}{c}72,38 \mathrm{~dB} \\
(23,79)\end{array}$ & $\begin{array}{c}205,59 \mathrm{bA} \\
(56,14)\end{array}$ & $\begin{array}{c}40,81 \mathrm{~dB} \\
(21,83)\end{array}$ \\
\hline
\end{tabular}

Em que: $\mathrm{TV}=$ Trametes versicolor $; \mathrm{GT}=$ Gloeophyllum trabeum; $*$ Para cada comprimento de onda, médias não seguidas por uma mesma letra minúscula na vertical ou uma mesma letra maiúscula na horizontal diferem estatisticamente a 5\% de probabilidade pelo teste de Scott-Knott. Os valores entre parênteses são referentes ao desvio padrão. 


\section{F - Alteração da intensidade de fluorescência emitida pela madeira de Eucalyptus saligna após exposição aos fungos apodrecedores}

\begin{tabular}{|c|c|c|c|c|}
\hline & \multicolumn{2}{|c|}{$422 \mathrm{~nm}$} & \multicolumn{2}{|c|}{$506 \mathrm{~nm}$} \\
\hline Período (Semanas) & $\mathrm{TV}$ & GT & TV & GT \\
\hline 0 & $\begin{array}{c}287,39 \mathrm{a} \\
(26,41)\end{array}$ & $\begin{array}{c}287,39 \mathrm{a} \\
(26,41)\end{array}$ & $\begin{array}{c}173,59 \mathrm{c} \\
(14,43)\end{array}$ & $\begin{array}{c}173,59 \mathrm{~b} \\
(14,43)\end{array}$ \\
\hline 1 & $\begin{array}{c}354,70 \mathrm{aA} \\
(115,40)\end{array}$ & $\begin{array}{c}294,63 \mathrm{aA} \\
(81,31)\end{array}$ & $\begin{array}{c}312,82 \mathrm{bA} \\
(75,07)\end{array}$ & $\begin{array}{c}292,06 \mathrm{aA} \\
(64,25)\end{array}$ \\
\hline 2 & $\begin{array}{c}344,27 \text { aA } \\
(58,37)\end{array}$ & $\begin{array}{c}125,17 \mathrm{bB} \\
(24,91)\end{array}$ & $\begin{array}{c}342,72 \mathrm{aA} \\
(64,31)\end{array}$ & $\begin{array}{c}163,09 \mathrm{bB} \\
(30,36)\end{array}$ \\
\hline 3 & $\begin{array}{c}307,85 \mathrm{aA} \\
(102,64)\end{array}$ & $\begin{array}{c}112,23 \mathrm{bB} \\
(61,16)\end{array}$ & $\begin{array}{c}307,09 \mathrm{bA} \\
(94,71)\end{array}$ & $\begin{array}{c}148,93 \mathrm{bB} \\
(71,04)\end{array}$ \\
\hline 4 & $\begin{array}{c}327,51 \mathrm{aA} \\
(72,42)\end{array}$ & $\begin{array}{c}78,86 \mathrm{cB} \\
(17,12)\end{array}$ & $\begin{array}{c}383,32 \mathrm{aA} \\
(78,73)\end{array}$ & $\begin{array}{c}110,43 \mathrm{cB} \\
(19,22)\end{array}$ \\
\hline 5 & $\begin{array}{c}298,70 \mathrm{aA} \\
(71,70)\end{array}$ & $\begin{array}{c}76,37 \mathrm{cB} \\
(13,09)\end{array}$ & $\begin{array}{c}300,56 \mathrm{bA} \\
(48,04)\end{array}$ & $\begin{array}{c}76,37 \mathrm{cB} \\
(13,09)\end{array}$ \\
\hline 6 & $\begin{array}{c}275,80 \text { aA } \\
(60,92)\end{array}$ & $\begin{array}{c}88,63 \mathrm{cB} \\
(40,03)\end{array}$ & $\begin{array}{c}275,04 \mathrm{bA} \\
(63,40)\end{array}$ & $\begin{array}{c}119,63 \mathrm{cB} \\
(50,54)\end{array}$ \\
\hline 7 & $\begin{array}{c}272,23 \mathrm{aA} \\
(102,46)\end{array}$ & $\begin{array}{c}98,92 \text { bB } \\
(58,80)\end{array}$ & $\begin{array}{c}248,05 \mathrm{cA} \\
(85,60)\end{array}$ & $\begin{array}{c}135,52 \mathrm{bB} \\
(77,89)\end{array}$ \\
\hline 8 & $\begin{array}{c}302,06 \mathrm{aA} \\
(94,69)\end{array}$ & $\begin{array}{c}105,63 \mathrm{bB} \\
(99,06)\end{array}$ & $\begin{array}{c}292,38 \text { bA } \\
(85,96)\end{array}$ & $\begin{array}{c}124,74 \mathrm{cB} \\
(77,40)\end{array}$ \\
\hline 9 & $\begin{array}{c}254,60 \mathrm{aA} \\
(92,89)\end{array}$ & $\begin{array}{c}79,31 \mathrm{cB} \\
(35,34)\end{array}$ & $\begin{array}{c}243,89 \mathrm{cA} \\
(77,68)\end{array}$ & $\begin{array}{c}103,99 \mathrm{cB} \\
(49,17)\end{array}$ \\
\hline 10 & $\begin{array}{c}237,49 \mathrm{aA} \\
(124,45)\end{array}$ & $\begin{array}{c}83,46 \mathrm{cB} \\
(34,11)\end{array}$ & $\begin{array}{c}236,56 \mathrm{cA} \\
(110,19)\end{array}$ & $\begin{array}{c}114,72 \mathrm{cB} \\
(50,63)\end{array}$ \\
\hline 11 & $\begin{array}{c}240,78 \mathrm{aA} \\
(98,90)\end{array}$ & $\begin{array}{c}72,45 \mathrm{cB} \\
(22,49)\end{array}$ & $\begin{array}{c}224,93 \mathrm{cA} \\
(83,88)\end{array}$ & $\begin{array}{c}102,27 \mathrm{cB} \\
(35,65)\end{array}$ \\
\hline 12 & $\begin{array}{c}297,51 \mathrm{aA} \\
(117,54)\end{array}$ & $\begin{array}{c}58,04 \mathrm{cB} \\
(19,92)\end{array}$ & $\begin{array}{c}282,03 \mathrm{bA} \\
(103,74)\end{array}$ & $\begin{array}{c}75,04 \mathrm{cB} \\
(23,50)\end{array}$ \\
\hline
\end{tabular}

Em que: $\mathrm{TV}=$ Trametes versicolor; $\mathrm{GT}=$ Gloeophyllum trabeum; $*$ Para cada comprimento de onda, médias não seguidas por uma mesma letra minúscula na vertical ou uma mesma letra maiúscula na horizontal diferem estatisticamente a 5\% de probabilidade pelo teste de Scott-Knott. Os valores entre parênteses são referentes ao desvio padrão. 